\title{
MISCELLANEOUS PAPERS
}

\author{
OF THE
}

\section{BOTANY OF MICHIGAN}

\author{
BY
}

CHARLES KEENE DODGE

QHI05 M5

A3

no. 6 


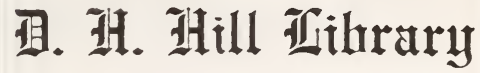

r Caralina tate Alutuprsity

QH105

M5

A3

no.6 
THIS BOOK IS DUE ON THE INDICATED BELOW AND IS JECT TO AN OVERDUE FIN POSTED AT THE CIRCULA DESK. 




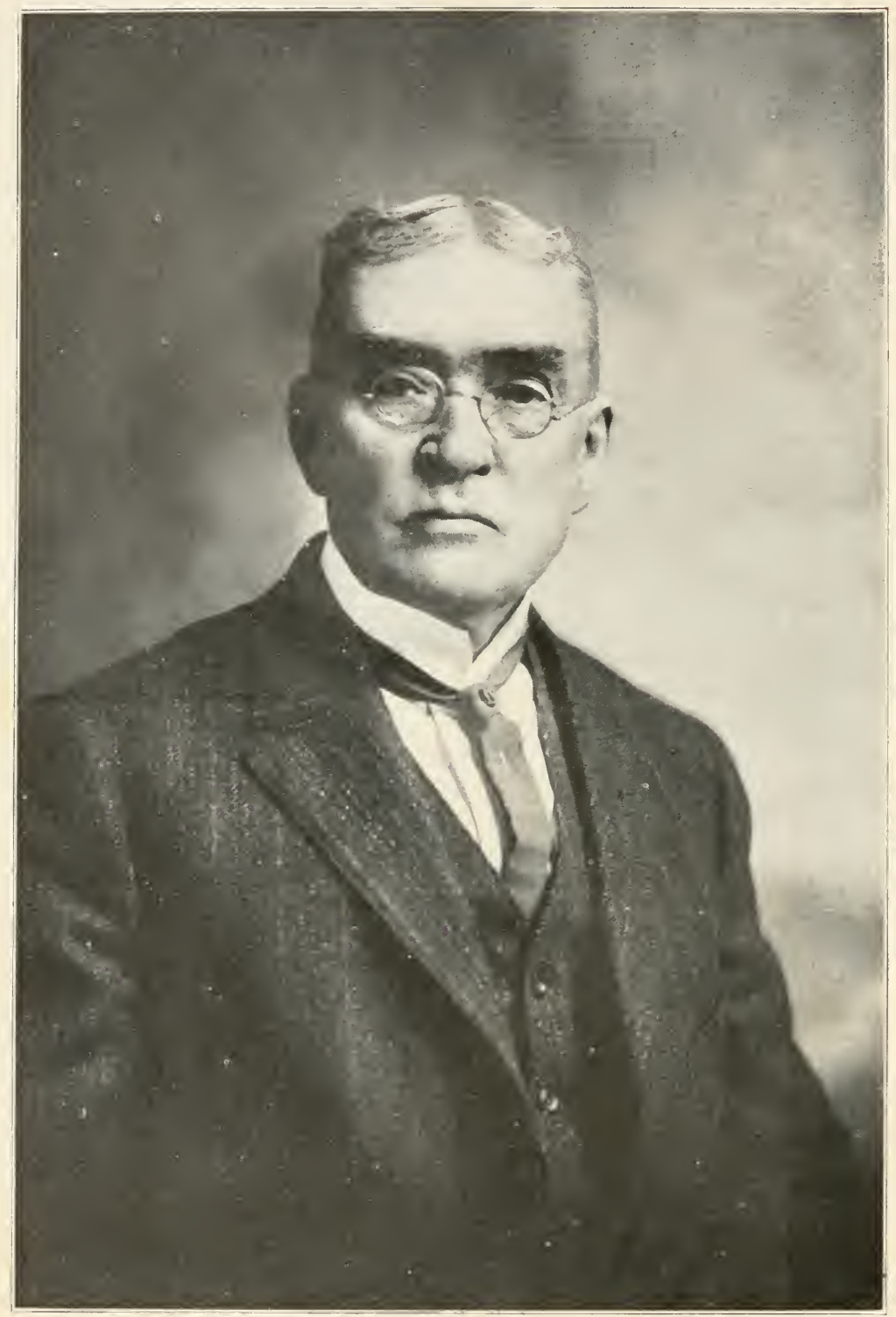

CHARLES KEENE DODGE 
MICHIGAN GEOLOGICAL AND BIOLOGICALISLRVEI.

Publication 31

Biological Series (;

\section{MISCELLANEOUS PAPERS}

ON THE

\section{BOTANY OF MICHIGAN}

$\mathrm{By}$

C. K. DODGE

PREPARED CNDER THE DIRECTION OF

ALEXANDER G. RUTHYEN

CHIEF NATERALIST

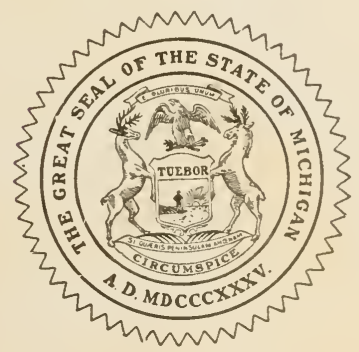

PUBLISHED AS A PART OF THE ANNUAL REPORT OF THE BOARD OF GEOLOGICAL SURVEY FOR 1920 

BOARD OF GEOLOGICAL AND BIOLOGICAL SURVEY, 1920

EX-OFFICIO :

The Governor of the State

HON. ALBERT E. SLEEPER

The Superintendent of Public Instruction

HON. THOMAS E. JOHNSON

The President of the State Board of Education

HON. FRED JEFFERS

DIRECTOR

R. A. SMITH

SCIENTIFIC ADVISORS

Geologists.--Dr. L. L. Hubbard, Houghton; Prof. W. H. Hohbs, Ann Arbor; Prof. W. H. Sherzer, Ypsilanti; Prof. E. C. Case, Ann Arbor.

Botanists.--Prof. E. A. Bessey, East Lansing; Prof. F. C. Newcomb, Ann Arbor.

Zoologists.-Prof. W. B. Barrows, East Lansing; Prof. J. Reighard, Ann Arbor; Dr. Bryant Walker, Detroit. 



\section{LETTERS OF 'TRANSIITTAL.}

To the Honorable the Board of Geological and Biological Surrey of the State of Michigan:

Gov. Albert E. Sleeper.

Hon. Thomas E. Johnson.

Hon. Fred Jeffers.

Gentlemen:-I have the honor to transmit herewith a manuscript containing miscellaneous papers on the botany of Michigan by the late Charles Keene Dodge, which is a contribution to the Biological Survey of the State authorized by Act No. 250 of the Session of 1905. I recommend that it be printed and bound as Publication 31, Biological series 6.

$$
\text { Respectfully yours, }
$$

R. A. SMITH,

Director.

Lansing, Michigan, December 20, 1920.

Sir:-I submit herewith for publication a number of manuscripts on the botany of Michigan prepared by the late Charles Keene Dodge. Most of the field work, the results of which these papers represent, was done under the direction of the Chief Naturalist and supported by the Survey.

\section{Respectfully,}

ALEXANDER (A. RETHVFX,

Chief Naturalist.

R. A. Smith, Director,

Michigan Geological and Biological survey. 



\section{PREFATORY NOTE}

\section{By Cecil Billington}

The several lists of plants comprising this volume were prepared by Charles Keene Dodge and include all of the unpublished manuscript left by him at his death. The papers were evidently complete, as they were marked "ready for the printer". As this volume will be the last publication of his writings it is deemed fitting to include a photograph of Mr. Dodge as a frontispiece, a short biological sketch, and a complete list, so far as they are known, of his publications.

\section{CHARLES KEENE DODGE}

\section{Born April 26, $1844 \quad$ Died March 22, 1918}

Charles Keene Dodge was born on a farm in the township of Blackman, Jackson County, Michigan, five miles north of the city of Jackson, April 26, 1844. He received his education entirely in the schools of his native state, graduating from a classical course at the University of Michigan, in 1870.

After leaving the University he taught school two years in Rockland, Michigan, and two years at Hancock, Michigan. He then studied law one year at Hancock, and in 1875 was admitted to the bar. He at once removed to Port Huron, Michigan, where he practiced his profession actively until 1893. At this time he was appointed to the staff of the United States customs office at Port Huron, which position he held until his death.

On August 4, 1897, he was married to Miss Millie Burns and they made their home in Port Huron with the exception of two years spent in the west and south.

Mr. Dodge began to take an interest in systematic botany at about the time he was admitted to the bar in 1875. He had had a six weeks' course in botany under Alexander Winchell and this, together with his natural love of the great out-of-doors furnished the incentive for an active interest in this subject. At one time he wrote "Without any" apparent mental effort I took to botany and was never able to let it alone. Everything described within the limits of Cray's Manual interested me. Woods, trees, fields, all formed an irresistible attraction.' He has told the writer how at first he would go to the woods or fields, bringing in a few plants carefully hidden under his coat so that his 
friends and neighbors could not see them. They nicknamed him "Posy" Dodge, which name he did not relish and tried to avoid occasion for its use as much as possible. However, this feeling gradually wore off, and Mr. Dodge, carrying his much-battered vasculum, was a familiar figure on the streets of Port Huron, particularly those streets leading to the country.

In his early study of botany he was greatly encouraged by the late Professor C. F. Wheeler and by Professor C. K. Davis, both of whom strongly urged him to take up systematic botany seriously, keep field notes, and establish an herbarium so that others might receive the benefit of his labor. He carried on this work until 1893, when he became dissatisfied with his collection and "threw most everything out of the back window and began over again". His ambition now was to have an herbarium embracing the flora of North America, and he engaged in exchanging material and building up a general collection. After a time, however, he came to the conclusion that he could do more effective work by confining himself to Michigan and adjacent territory, and his last herbarium labels read: "Plants of the Creat Lakes Region."

In 1908 he became associated with the Michigan Geological and Biological Survey, and through the aid and encouragement of Dr. A. G. Ruthven, Chief Naturalist of the Survey and Director of the Museum of Zoology at the University of-Michigan, Mr. Dodge made many of his later and more important botanical expeditions to Chippewa, Luce, Alger, Schoolcraft, Marquette, Houghton and other northern counties. In the fall of 1917 he began an investigation of the flora of Berrien County, which he did not live to complete.

As a recognition of his services in extending the knowledge of the flora of Michigan, he was appointed, in 1912, Associate Curator of Botany in the Museum of Zoology, University of Michigan, and continued a valued member of the staff until his death. His splendid herbarium, consisting of between 30,000 and 40,000 finely prepared specimens was left at his death to the Museum of Zoology at Ann Arbor, where it will be available to other students of systematic botany.

Mr. Dodge was an excellent correspondent and numbered the foremost botanists of the country among his friencls. He was not interested in the study of plants for the purpose of naming new species, and had little use for the "splitters", as he called that group of botanists who are continually creating new genera and species by breaking up the old groups. He was interested principally, as he put it, "in finding out what grows wild in Michigan", and he often expressed the wish that he might live until he had made a complete survey of the State. He confined his botanical publications mainly to lists of plants of Michigan and Ontario, but had under preparation at the time of his death an ambitious book giving a list of all the known higher plants of the Great Lakes 
Region, with their scientific and common names, medicinal properties, and any other obtainable information. If he had lived to complete this work it would have been a very valuable addition to the botanical information of the district.

So great was his interest in botany, and so strong was his desire that others should know the joy of plant study, that he gave to the high school in Port Huron a nearly complete set of the plants of that vicinity. He was also very generous with his papered specimens, and there are doubtless few herbariums of importance in the country that have not some of his material. He was always willing and anxious to help beginners in systematic botany and took many long tramps, through territory which afforded him nothing new, to assist them in adding to their collections. Any and all information he possessed was freely given to others.

He was an indefatigable worker, whether in the field or his herbarium. The writer had the privilege of accompanying him on some of his later excursions, and notwithstanding his age Mr. Dodge could hold his own on a tramp with most of the younger men of a party. Up to the last year of his life he would tramp all day in the hot sun and work far into the night putting up his specimens for drying, and seemingly be as fresh as ever for the next day's tramping. He would examine herbarium specimens until the small hours of the morning, and it always afforded him great pleasure when he found a plant he had not seen before. In later years he belonged to a nature club in Detroit and frequently took the long car ride necessary to attend their meetings. He was keenly interested in all branches of natural science, but would not allow himself to wander far from his botanical work.

In spite of his all-absorbing interest in botany he was active in local civic affairs and contended strongly with interests in Port Huron which sought to destroy in a measure the beauty of his home city. He took more than an ordinary interest in political affairs, both state and national, and his advanced age was undoubtedly all that kept him from joining in the activities of the Great War, the events of which he followed closely. His love. of nature and his kindly disposition made him tolerant of his fellow man, and it was a rare thing to hear him speak ill of anyone.

It was apparent to those who saw Mr. Dodge in the latter part of 1917 that his health was failing. He had been suffering for some time, and the condition continued to grow acute until the next March, when he determined to undergo an operation and accordingly went to the University Hospital at Ann Arbor for that purpose. The shock of the operation proved more than he could stand, and he died on March 22, 1918. With his passing the science of botany in Michigan suffered irreparably, and his many friends and associates lost a personality which had long been an inspiration and help to them. 


\section{BIBLIOGRAPHY OF CHARLES KEENE DODGE}

Flora of St. Clair County. Ann. Rept. Mich. Horticultural Soc., 1899.

Observations on the Crataegi in the Vicinity of Port Huron. Ann. Rept. Mich. Acad. Sci., 1907, 123-125.

A Botanical Trip to Thunder Bay Island. Ibid., 1908, 40-42.

Results of the Mershon Expedition to the Charity Islands, Lake Huron. Ibid., 1911, 173-191.

Catalog of Plants, in Biological Survey of the Sand Dune Region on the South Shore of Saginaw Bay, Michigan. Mich. Geol. and Biol. Surv., Pub. 4, Biol. Ser. $2,1911,65-121$.

The Fern Flora of Michigan. The Fern Bulletin, Vol. XX, 1912, No. 1, 6-S.

Flora of St. Clair County. History of St. Clair County, 1912, Vol. I, Chap. V, $30-41$.

The Flowering Plants, Ferns and Their Allies of Mackinac Island. Ann. Rept. Mich. Acad. Sci., 1913, 218-23S.

The Flowering Plants, Ferns and Fern Allies Growing Without Cultivation in Lambton County, Ontario. Ibid., 1914, 132-201.

Annotated List of Flowering Plants and Ferns of Point Pelee, Ontario, and Neighboring District. Canada Dept. of Mines, Ottawa, 1914.

Contributions to the Botany of Michigan, I. Misc. Publications, Mus. of Zool., Univ. of Mich., No. 4, February, 1918, 1-4.

Contributions to the Botany of Michigan, II. Misc. Publications, Mus. of Zool., Univ. of Mich., No. 5, July, 1918. [Posthumous.] 


\section{CON'TENTS}

Letters of Transmittal................................

Bibliography of Charles Keene Dodge. . . . . . . . . . . . . . . . . . . . . . . . .

Observations on the Flowering Plants, Ferns, and Fern Allies on and near the shore of Lake Huron from Linwood Park near Bay City, Bay County, to Mackinaw City, Cheboygan County, including the vicinity of St. Ignace, Mackinac and Bois IBlanc Islands, Mackinac County, Michigan, by C. K. Dodge. . . . . . . . . . . . .

Observations on the Flowering Plants, Ferns, and Fern Allies growing wild in Schoolcraft County and Vicinity in the Upper Peninsula of Michigan in 1915 , by C. $\mathrm{K}$. Dodge. . . . . . . . . . . . . . . . . . . . . . . . . . .

Observations on the Wild Plants at Whitefish Point and Vermilion, near the Sonth Shore of Lake Superior, and other parts of Chippewa County, Michigan, in 1914, by C. K. Dodge . . . . . . . . . . . . . . . . . . . . . . .

Observations on the Flowering Plants, Ferns, and Fern Allies growing without Cultivation in Tuscola County, Michigan, by C. K. Dodge.................

\section{ILLUSTRATIONS}

Portrait of Charles Keene Dodge. 

MIECELLANEOUS PAPERS

ON THE

BOTANY OF MICHIGAN

BY

C. K. Dodge 
OBSERVATIONS ON THE FLOWERING PLANTS, FERNS, AND FERN ALLIES ON AND NEAR THE SHORE OF LAKE HURON FROM LINWOOD PARK NEAR BAY CITY, BAY COCNTY, TO MACKINAW CITY, CHEBOYGAN COUNTY, INCLUDING THE VICINITY OF ST. IGNACE, MACKINAC AND BOIS BLANC ISLANDS, MACKINAC COUNTY, MICHIGAN.

Through a suggestion of the late Professor C. A. Davis, the writer for a number of years had contemplated a botanical examination of the eastern part of the lower peninsula of Michigan along the lakes and their connecting waters from the southern state line to Mackinaw City in Cheboygan County. The opportunity to begin was offered in 1908, under the direction of Dr. A. G. Ruthven while making a biological survey of the sand dune region in Huron County on the south shore of Saginaw Bay. During that year and in 1909 the whole shore line and vicinity of Huron County and nearly all the islands in Saginaw Bay, were earefully examined, the results reported and published.* In 1910 an examination of the Saginaw Bay shore was extended west to the border of Bay County and most of Tuscola County looked over. The plants noticed have been catalogued but not published. In 1911 it was decided that a botanical survey of the Lake Huron Shore farther north was desirable, provision made for it, and the work begun in June 1912 and followed up from time to time to and including a part of 1914 .

\section{Ground Traversed}

The work was begun June 18, 1912, at a point two miles south of Linwood Park in Bay County, going northward as near Lake Huron as possible. Much of the journey was made over new and almost impassable roads near the lake, plenty of time being taken to examine the vegetation. Stops and examinations were made at the following places in 1912, and the country examined about and between them: Linwood and Pinconning, Bay County; Omer and Au Gres, Arenac County; Tawas City, Oscoda and Au Sable, Iosco County; Harrisville, Aleona County; Alpena, Alpena County; Rogers, Presque Isle County; Cheboygan and Mackinaw City, Cheboygan County; St. Ignace and Mackinac Island, Mackinac County. Afterward in 1913 many of these places were revisited and in arddition, Bois Blanc Island and Round Island, Mackinac County; Hillman, Atlanta, and Lewiston, Montmoreney County; Mio, Oscoda County; and Rose City, Ogemaw County. The 
following list of plants covers the region above mentioned. Vegetation from the south line of Huron County to the south state line has also been examined as well as might be but observations covering that part are reserved for another report. To indicate what has been attempted about the Great Lakes it may be observed here also that the plants of Lambton County, Ontario (the county in Ontario lying opposite St. Clair (ounty, Michigan) have been catalogued and published. ${ }^{1}$ Research has been carried as far as Bruce County and Georgian Bay, in Ontario. And investigations have been made in Ontario south along St. Clair River around Lake St. Clair to Detroit River, along that river to Lake Frie and east on the north shore of Lake Erie to Point Pelee including Pelee Island in Lake Erie. In 1910-11, Essex County, Ontario, opposite Wayne County, Michigan, was examined, plants listed and a report made which was published by the Dominion Government of Ontario. ${ }^{2}$

\section{Lake Huron Shore}

The distance from Linwood Park in Bay County along the Lake Huron shore to Mackinaw City is approximately 200 miles. A full description here will not be attempted, general features only being mentioned. From Bay City around to Au Gres in Arenac County the shore of Saginaw Bay is very low, and the land back of it is very low, flat, and difficult to drain. The Bay is shallow for a long distance out and much obscured by a dense growth of water loving plants. From Au Gres to Mackinaw City the beach is generally sandy, but occasionally backed by a bluff or sand ridge as below and above Harrisville. The rock outcroppings are comparatively few. There are quarries at Alpena and near Rogers.

\section{Sone Land and Surface Feateres}

The land in Bay and Arenac counties is generally very flat, and was formerly covered mostly with a dense growth of elm, red maple, ash, and mountain maple. In Ogemaw, Oscoda, Montmorency and Presque Isle: counties there is much hilly and rough country. About Rose City, Ogemaw County, the hills are covered with hardwoods and the soil good. Jack pine plains, swamps, and marshy areas are frequent as are ponds and small lakes. Small hardwood tracts and streaks were noticed throughout. Evidence of destructive and devastating forest fires were seen throughout. There are thousands of acres of dead standing and fallen timbers yet to be seen. The complete destruction by an invading forest fire of the villages of Au Sable and Oscoda, Iosco County, in 1911 was still prominently in evidence June 23, 1912.

1The Flowering Plants, Ferns and Fern Allies Growing without Cultivation in Lambton Co., Ontario. Slxteenth Annual Report Michigan Academy of Science, p 132.

${ }^{2}$ Annoted List of Flowering Plants and Ferns of Point Pelee, Ontario and Neighboring Districts by C. K. Dodge. Canada, Department of Mines, Geological Survey. 
Scarcely any attempt had yet been made to rebuild except here and there a small structure. These two villages were completely swept out of existence. Sawmills, piles of lumber, stores, residences, bridges. and even street shade trees were consumed. No substantial business had yet returned. It is a remarkable example of the sudden and complete blotting out of villages and business by fire.

\section{Limitation of Species North and South Near and Along Lake Huron SHore}

In the following annotated list of plants the limitation of any species north or south in the region visited is noted, but it seemed that several plants were worthy of special mention. The last individual specimen of shellbark hickory was noticed in the northern part of Arenac County, last yellow barked oak near Oscoda in Iosco County, white oak near Cedar Lake in Alcona County, Nyssa sylvatica near Omer in Arenac County. Acer pennsylvanicum was observed first about two miles north of Harrisville in Alcona County, and it was common from there northward. The white flowering raspberry, Rubus parviflorus, was first seen a few miles northwest of Rogers in Presque Isle County, and was abundant from that point northward, while the last of the purple flowering raspberry, Rubus odoratus, was noted there and not again observed northward.

\section{Beach Plants}

Particular attention was paid to characteristic beach plants. For the whole distance there was not much rariation. The following appeared throughout: Beach pea, I'itcher's thistle, tall wormwood, sea sand reed, long-leaved reed grass, Agropyron dasystachyum, Elymus canadensis, and Cakile edentula.

The writer is much indebted to Agnes Chase, scientific assistant in systematic agrostology, United States Department of Agriculture, for examining the grasses; to Kenneth K. Mackenzie of New York City for looking over the Carices and other difficult species; to F. F. Forbes of Brookline, Massachusetts, for naming the willows; and to M. "I. Fernald of the Gray Herbarium at Harvard College for examining the lacciniums and other plants.

Ancotated List

POLYPODIACEAE. Fern Family

Phegopteris dryopteris (L.) Fée. Oak fern. Rich open woods throughout. Common.

Adiantum pedatum L. Maidenhair. Rich open or partially shaded ground. Frequent. 
Pteris aquilina I. Common brake. Abundant throughout in damp, dry, open or shaded ground.

Asplenium filix-femina (L.) Bernh. Lady fern. In damp shaded places throughout. Plentiful.

Aspidium thelypteris (L.) Sw. Marsh shield-fern. Very common throughout in damp marshy places or rich open woods.

Aspidium marginale (L.) Sw. Evergreen wood-fern. Rich shaded ground. Frequent throughout.

Aspidium cristatum (L.) Sw. Crested shield-fern. In swampy open or partially shaded places. Frequent.

Aspidium spinulosum (O. F. Müller) Sw. Spinulose shield-fern. Rich open woods throughout. Common.

Aspidium spinulosum intermedium (Muhl.) D. C. Eaton. American shield-fern. Damp rich woods and thickets. Frequent throughout.

Cystopteris bulbifera (L.) Bernh. Bulblet Cystopteris. Common on rocky ground and in shaded places. Frequent throughout. Very abundant on Mackinac Island.

Cystoperis fragilis (L.) Bernh. Brittle fern. Frequent in rich woods throughout.

Onoclea sensibilis L. Sensitive fern. Damp, open or shaded ground. Frequent and often abundant throughout.

Onoclea struthiopteris (L.) Hoffm. Ostrich fern. Fine specimens near Alpena and near Rogers in Presque Isle County. In alluvial shaded ground along streams. Throughout.

\section{OSMUNDACEAE. Flowering Fern Family}

Osmunda regalis $\mathrm{L}$. Flowering fern. Wet swampy open or shaded places. Seldom abundant.

Osmunda claytoniana L. Clayton's fern. Noticed near Omer, Arenac County, Harrisville, Alcona County, and Rogers, Presque Isle County. Frequent throughout in open or partially shaded rich ground.

Osmunda cinnamomea L. Cimnamon fern. In damp open or shaded ground throughout, but seldom abundant. Fine specimens observed.

OPHIOGLOSSACEAE. Adder's Tongue Family

Botrychium virginianum (L.) Sw. Rattlesnake fern. Rich shaded ground. Plentiful throughout.

\section{EQUISETACEAE. Horsetail Family}

Equisetum arvense L. Common horsetail. Damp sandy open ground. Common throughout.

Equisetum sylvaticum L. Wood horsetail. Damp shaded ground. Frequent throughout. 
Equisetum fluviatile L. Swamp horsetail. Pipes. Wet swampy places, often in shallow water. Abundant.

Equisetum hyemale intermedium. A. A. Eaton. Srouring rush. Dry open or shaded ground. Plentiful throughout.

Equisetum hyemale robustum (A. Br.) A. A. Faton. Stout scouring rush. Dry, open or partially shaded ground. Occasional throughout.

Equisetum variegatum Schleich. Variegated equisetum. Usually in damp sand on or near Lake Huron beach. Often plentiful.

Equiselum scirpoides Michx. Sedge-like equisetum. Dryish, open or shaded places. Conmon and in spots abundant about St. Ignace and on Mackinac Island.

\section{LYCOPODIACEAE. Club Moss Family}

Lycopodium lucidulum Michx. Shining elub-moss. Damp rich woorls. Frequent throughout.

Lycopodium annotinum L. Stiff (rlub-moss. Usually in rich shaded ground. Frequent throughout. Plentiful in hardwoods.

Lycopodium clavatum L. Common club-moss. Usually in dryish shaded ground. Frequent throughout.

Lycopodium obscurum L. Ground pine. In woods. Frequent throughout.

Lycopodium obscurum dendioideum (Michx.) D. C. Eaton. Tree-like ground pine. Noticed mostly in rich woods. Frequent throughout.

Lycopodium complanatum L. Trailing ehristmas-green. Dryish shaded ground. Occasional throughout.

\section{SELAGINELLACEAE. Selaginella Family}

Selaginella selaginoides (L.) Link. Collected on Mackinac Island. By E. J. Hill according to botanical notes of the late Prof. C. F. Wheeler.

Selaginella apus (L.) Spring. Creeping selaginella. Damp open ground. Frequent throughout. A small very pretty moss-like plant.

TAXACEAE. Yew Family

Taxus canadensis Marsh. American yew. In the shade of evergreen. or in damp hardwoors and often abundant from Bay County to Mackinac Islant, Mackinac County.

\section{PINACEAE. Pine Family}

Pinus strobus L. White pine. smal! trees throughout and a few large ones. Formerly very abundant. Thousands of seedlings and small trees noticed.

Pinus banksiana Lamb. Jack pine. Noticed from near Au Gres in Iosco County to Rogers in Presque Isle County. Very abundant in 
Iosco County and often in large groves. Southern limit on east side of the State near I'ort Austin, Huron County. In Presque Isle County near Onaway and near Mio, Oscoda County; often one foot and more in diameter, straight and free from limbs, being often cut for lumber.

Pinus resinosa Ait. Red pine. Norway pine. Frequent and often abundant in dry sandy ground from Arenac County to Mackinac Island Small trees and seedlings abundant. Southern limit on east side of state near Port Huron, St. Clair County.

Larix: laricina (Du Roi) Koch. Tamarack. Scattering throughout and trees usually small in wet swanpy ground. Reported as formerly abundant.

Picea canadensis (Mill.) BSP. White spruce. Occasional from near Bay City (G. M. Bradford) to Mackinaw City in dryish ground. Abundant about St. Ignace and on Mackinac Island.

Picea mariana (Mill.) BSP. Black spruce. In swamps often with tamaracks. Frequent throughout.

Abies balsamea (L.) Mill. Balsam. First noticed south of Tawas City in Iosco County and frequent from there to Mackinac Island where it is abundant. Southern limit on east side of State near Port Austin in Huron County.

Tsuga canadensis (I.) Carr. Hemlock. Occasional from Bay County to Mackinac Island. Trees usually small. Southern limit on east side of State near Port Huron, St. Clair County.

Thuja occidentalis L. Arbor vitae. White cedar. More or less abundant throughout near the Lake Huron shore. Trees usually small. Formerly often abundant in "cedar swamps" now rlestroyed by lumbering and fires. Southern limit near shore on east side of State is Port Huron, St. Clair County.

Juniperus communis L. Common juniper. Near Alpena and St. Ignace. Apparently infrequent.

Juniperus communis depressa Ait. I.ow juniper. Common on or near the Lake Huron shore from Bay County to Mackinaw City. Abundant about St. Ignace and on Mackinac Island.

Juniperus horizontalis Moench. Shrubby red cedar. First noticed on and near the sandy beach of Lake Huron and on Thunder Bay Island in Alpena County. Frequent from there to St. Ignace.

TYPHACEAE. Cat-tail Family

Typha latifolia L. Common cat-tail. Common and often abundant throughout in wet swampy places and shallow water.

Typha angustifolia L. Narrow-leaved cat-tail. Bay County in swampy grount. G. M. Bradford. 
SPARGANIACEAE. Bur-reed Family

Sparganium eurycarpum Engelm. Broad-fruited bur-reed. In shallow water and damp places from Bay County to St. Ignace and on Mackinac Island. Common.

Sparganium americanum androcladum (Engelm.) Fernald \& Eames. Branching bur-reed. Bay County in swampy ground. G. MI. Bradford.

NAJADACEAE. Pondweed Family

Potamogeton natans I. Common floating pondweed. In coves of slow streams and very wet places near Lake Huron shore. Occasional throughout.

Potamogeton americamus C. \& S. Long-leaved pondweed. In ponds and coves of slow streams. Frequent throughout.

\section{JUNCAGINACEAE. Arrow Grass Family}

Triglochin maritima L. Seaside arrow grass. Wet marshy ground. Frequent throughout.

Triglochin palustris I. Marsh arrow grass. In damp open ground on east side of Mackinac Island, and on Bois Blanc Island, Mackinac County. Plentiful. Probably plentiful throughout but overlooked.

\section{ALISMACEAE. Water-plantain Family}

Sagittaria latifolia Willd. Broad-leaved arrow-head. In shallow water and damp places from Bay County to Mackinaw City. Plentiful throughout.

Alisma plantago-aquatica I. Water plantain. In shallow water and muddy places. Frequent throughout.

\section{HYDROCHARITACEAE. Frog's Bit Family}

Elodea canadensis Michx. Water-weed. Ponds, small lakes and in stagnant or slowly moving water. Plentiful throughout.

Vallisneria spiralis I. Wild celery. In slowly moving water of streams near the Lake Huron shore from Bay County to Mackinaw City. Plentiful throughout.

\section{GRAMINEAE. Grass Family}

Andropogon scoparius Michx. Broom beard-grass. Dry open ground from Bay County to Bois Blanc Island, Mackinac County. Frequent. Common on jack pine plains in Presque Isle, Montmorency, Oscoda and Ogemaw counties.

Andropogon furcatus Muhl. Forked beard-grass. Dry open ground from Bay County to St. Ignace, Mackinac County. Frequent. Nore 
frequent on the jack pine plains of Presque Isle, Montmorency, Oscoda and Ogemaw counties.

Digitaria humifusa Pers. Small crab-grass. Cultivated and waste grounds from Bay County to Mackinaw City, Cheboygan County. Frequent.

Ligitaria sanguinalis (L.) Scop. Crab-grass. A weed about fishery and farm buildings, in fields and gardens. Plentiful throughout.

Panicum capillare L. Old-witch grass. A common weed about cities, villages, in fields, and gardens. Plentiful throughout.

Panicum Alexile (Gattinger) Scribn. Wiry witch-grass. Damp marshy open ground from Bay County to Bois Blane Island, Mackinac County. Frequent.

Panicum depauperatum Muhl. Starved panicum. In dry open ground. Frequent throughout.

Panicum boreale Nash. Northern panicum. In damp grassy open ground near Linwood, Bay County. Plentiful at this place.

Panicum lindheimeri Nash. Lindheimer's panic-grass. Dry open ground on Bois Blanc Island. Apparently infrequent.

Panicum tsugetorum Nash. Hemlock panicum. In sandy ground near Au Gres, Arenac County. Plentiful.

Echinochloa crusgalli (L.) Beauv. Barnyard grass. In and near cultivated grounds and in damp places. Plentiful throughout.

Setaria glauca (L.) Beauv. Foxtail. A weed about dwellings and in cultivated grounds. Common throughout.

Setaria viridis (L.) Beauv. Green foxtail. A weed in gardens and other cultivated grounds. Frequent throughout.

Cenchrus carolinianus Walt. Sandbur. Bur grass. Sandy roadsides, Sandy pastures and fields, and in waste places of cities and villages. Frequent throughout.

Zizania palustris L. Indian rice. Wild rice. Occasional in shallow water as if introduced.

Zizania aquatica L. Water oats. In mud and shallow water. Infrequent.

Leersia oryzoides (L.) Sw. Rice cut-grass. Scratch grass. Ditches, low hanks of small streams and low places. Frequent throughout.

Phalaris arundinacea L. Reed canary grass. In wet marshy open places. Frequent throughout.

Phalaris arundinacea picta L. Ribbon grass. Noticed in many wet marshy places as an apparently permanent escape from cultivation.

Hierochloe odorata (L.) Wahlenb. Vanilla grass. Abundant in spots on the east sicle of Mackinac Island. Probably frequent throughout but overlooked.

Milium effusum L. Millet grass. Rich shaded ground especially in rich woods. Frequent throughout. 
Oryzopsis pungens (Farr.) Hitche. Slender mountain rice. Dry open ground from Bay County to Mackinac Island, Mackinac County. Frequent.

Oryzopsis asperifolia Michx. White-grained mountain rice. Dryish open or partially shaded ground. Frequent throughout.

Stipa spartea Trin. Porcupine grass. In sandy ground near Linwood, Bay County. Plentiful near the sandy beach at this place.

Muhlenberyia racemosa (Michx.) BSP. Marsh muhlenbergia. Damp open ground with other grasses. Frequent throughout.

Brachyelytrum erectum (Schreb.) Beauv. Bearded short-husk. Rich woods. Frequent throughout.

Phleum pratense L. Timothy. Along roads and in waste places. Apparently introduced. Plentiful throughout.

Alopercurus geniculatus aristulatus Torr. Floating foxtail. In very wet places near Linwood, Bay County. Plentiful. Probably frequent throughout.

Sporobolus cryptandrus (Torr.) Gray. Sand drop-seed. On and near sandy beach of Lake Huron. Frequent throughout.

Agrostis alba L. Red top. Damp rich meadow-like ground and often abundant in damp sand. Plentiful throughout.

Agrostis hyemalis (Walt.) BSP. Hair grass. Dry or moist open ground. Frequent throughout. Plentiful on jack pine plains in Presque Isle, Montmorency, Oscoda and Ogemaw counties.

Calamovilfa longifolia (Hook.) Hack. Long-leaved reed-grass. On the sandy beach of Lake Huron, usually above the wave line. An efficient sand binder against the action of winds. Frequent throughout. Seldom abundant.

Calamagrostis canadensis (Michx.) Beauv. Blue-joint grass. In wet open marshy places. Often abundant throughout.

Ammophila arenaria (I.) Link. Sea sand-reed. In spots throughout on the sandy beach of Lake Huron. Often abundant below the wave line. One of the best known sand binders against the action of both wind and wave.

Deschampsia flexuosa (I.) Trin. Common hair grass. Near Au Sable. Iosco County. In dry shaded ground. Noticed as frequent throughout.

Deschampsia caespitosa (L.) Beauv. Tufted hair-grass. Wet open ground on Bois Blanc Island. Apparently infrequent.

Danthonia spicata (L.) Beauv. Common wild oat grass. Dry sandy open ground. Common throughout.

Phragmites communis Trin. Reed. Nargins of swamps and in marshy ground. Frequent throughout.

Eragrostis pilosa (L.) Beauv. Tufted eragrostis. Sandy open ground. Frequent near cities and villages. 
Eragrostis megastachya (Koeler) Link. Strong-scented love-grass. Gardens and waste places. Frequent throughout.

Melica striata (Michx.) Hitchc. Purple oat. In spruce-cedar woods near St. Ignace. Apparently infrequent.

Dactylis glomerate L. Orchard grass. Waste places, streets and roadsides in and near cities and villages. Frequent throughout.

Poa annua L. Low spear grass. Roadsides and in lawns and yards of cities and villages. Plentiful throughout.

Poa compressa L. Canada blue grass. Dry open ground. Frequent throughout.

Poa triflora Gilib. Fowl meadow grass. In damp ground on the east side of Mackinac Island. Apparently infrequent. Perhaps overlooked.

Poa pratensis L. June grass. In patches throughout. Seldom thriving in dry sandy ground. Common in cities and villages and in old pastures.

Poa debilis Torr. Weak spear grass. In open rocky places on the east side of Mackinac Island. Apparently infrequent. Perhaps overlooked.

Glyceria canadensis (Michx.) Trin. Rattlesnake grass. Damp open places. Plentiful throughout.

Glyceria nervata (Willd.) Trin. Nerved manna-grass. In damp open or partially shaded ground. Common throughout.

Glyceria grandis Wats. Reed meadow grass. Banks of streams and wet meadow-like ground. Frequent throughout.

Festuca octoflora Walt. Slender fescue-grass. In dry open or slightly shaded ground. Frequent throughout.

Festuca occidentalis Hook. Western fescue-grass. Woods about St. Ignace and on Mackinac Island. Plentiful. Apparently infrequent.

Festuca orina I. Sheep's fescue. Open sandy ground. Frequent throughout.

Bromus inermis Leyss. Hungarian brome-grass. Apparently a permanent escape from cultivation in old fields above Alpena. Apparently infrequent.

Bromus seculinus L. Common chess. Waste places of cities and villages and about farm dwellings. Frequent throughout.

Bromus citiatus L. Fringed broom-grass. Damp slightly shaded ground. Frequent throughout.

Bromus lialmii Gray. Wild chess. Near St. Ignace and on Mackinac Island in damp open ground. Plentiful. Also near Mio, Oscoda County.

Bromus pumpelliamus melicoides shear. Pumpelly's brome-grass. Plentiful on the sandy beach at Mackinaw City. Apparently well established. A western grass perhaps not before noticed in Michigan. Not yet included in our present manuals. Said to exist in Illinois. (tgnes (hase.) 
Agropyron smithii Rydb. Western wheat-grass. In cities, villages and waste places from Bay County to Bois Blanc Island, Mackinac County. Frequent.

Agropyron repens (L.) Beauv. Quack-grass. In cities, villages and cultivated grounds. Frequent throughout.

Agropyron dasystachyum (Hook.) Scribn. Northern wheat-grass. In spots on the sandy beach of Lake Huron. A sand binder against the action of wind. Seldom abundant. Occasional throughout.

Agropyron caninum (I.) Beauv. Awned sheat-grass. Near Linwood in Bay County in dryish open ground. Apparently infrequent.

Secale cereale L. Rye. On the sandy beach of Lake Huron near Linwood in Bay County. Apparently a permanent escape. Plentiful.

Hordeum jubatum L. Squirrel-tail grass. Noticed now in waste places of all cities and villages. Frequent throughout. From the west.

Elymus virginicus L. Virginia wild rye. In damp shaded ground. Apparently infrequent.

Elymus canadensis L. Nodding wild rye. On and near sandy beach of Lake Huron. A good sand binder against the action of wind. Plentiful throughout.

Hystrix patula Moench. Bottle-brush grass. Open or shaded ground from Bay County to Mackinaw City. Frequent. Noticed in particular near Mio, Oscoda County.

\section{CYPERACEAE. Sedge Family}

Cyperus filiculmis Vahl. Slender cyperus. Dry open ground near Mio, Oscoda County. Plentiful.

Dulichium arundinaceum (L.) Britton. Dulichium. In wet open places and on borders of ponds. Plentiful throughout.

Eleocharis obtusa (Willd.) Schultes. Blunt spike-rush. In damp, muddy, mostly open places, often in damp sand. Frequent throughout.

Eleocharis palustris (L.) R. \& S. Creeping spike-rush. In wet marshy open ground. Plentiful throughout.

Eleocharis palustris glaucescens (Willd.) Gray. Slender creeping spike-rush. In damp open ground at St. Ignace. Plentiful. Perhaps existing throughout, but overlooked.

Eleocharis palustris vigens Bailey. Large creeping spike-rush. In shallow water of small lakes, and slow streams. Frequent throughout.

Eleocharis acicularis (L.) R. \& S. Needle spike-rush. Wet muddy or wet sandy places near Lake Huron shore, and in springy spots. Irequent throughout.

Eleocharis tenuis (Willd.) Schultes. Slender spike-rush. Wet marshy open places. Frequent throughout.

Eleocharis rostellata Torr. Beaked spike-rush. On the east side of 
Mackinac Island, in wet swampy ground. Plentiful at that place. Apparently infrequent.

Scirpus pauciflorus Lightf. Few-flowered club-rush. Wet open ground near Alpena along Lake Huron shore. Abundant in spots throughout.

Scirpus caespitosus L. Tufted club-rush. Wet marshy open places on Bois Blanc Island. Frequent.

Scirpus hudsonianus (Michx.) Fernald. Alpine cotton-grass. Open boggy places in Presque Isle County. Plentiful.

Scirpus subterminalis Torr. Water club-rush. Ponds and borders of slow streams. Frequent throughout.

Scirpus americanus Pers. Three-square. In very wet places along the Lake Huron shore, on borders of small lakes and along low banks of streams. Plentiful throughout.

Scirpus validus Vahl. Great bulrush. In wet marshy places near shore of Lake Huron and about small lakes. Plentiful throughout.

Scirpus occidentalis (Wats.) Chase. Western bulrush. From Bay County to Mackinac Island. Very abundant in shallow water of Lake Huron above Bay City. Also in marshes, swamps, on the margins of streams, and in and about small lakes.

Scirpus fluviatilis (Torr.) Gray. River bulrush. In very wet places near Linwood, Bay County. Plentiful.

Scirpus atrovirens Muhl. Dark green bulrush. Marshy open ground. Common throughout.

Scirpus cyperinus pelius Fernald. Wool-grass. In damp marshy open places. Common throughout.

Eriophorum callitrix Cham. Sheathed cotton-grass. In open bogs. Frequent throughout.

Eriophorum gracile Roth. Slender cotton-grass. Near lighthouse in Presque Isle County, in a swampy open place. Frequent throughout.

Eriophorum viridi-carinatum (Engelm.) Fernald. Tall cotton-grass. Common throughout in open or partially shaded boggy places.

Eriophorum virginicum I. Virginia cotton-grass. Bogs and damp meadow-like ground. Frequent throughout.

Rynchospora alba (L.) Tahl. White beaked-rush. Open bogs. Frequent throughout.

Rynchospora capillacea Torr. Capillary beaked-rush. Wet open ground. Plentiful throughout.

Cladium mariscoides (Muhl.) Torr. Twig rush. Bogs and wet sandy ground. Common throughout.

Carex scoparia Schkuhr. Pointed broom sedge. Low open ground. Frequent throughout.

Carex tribuloides Wahlenb. Blunt brown sedge. Damp, usually shaded ground. Frequent throughout. 
Carex tribuloides reducta Bailey. Smaller blunt brown sedge. Damp, partially shaded ground. Frequent throughout.

Carex siccata Bailey. Hillside sedge. Dry open ground from Bay County to St. Ignace, Mackinac County. Plentiful.

Carex cristata Schwein. Crested sedge. Usually in wet sharled ground. Frequent throughout.

Carex mirabilis Dewey. Larger straw sedge. Dry open or partially shaded ground. Frequent throughout.

Carex mirabilis tincta Fernald. Smaller straw sedge. Dry open or partially shaded ground, Bois Blane Island. Plentiful. Probably to be found throughout, but overlookerl.

Carex straminea Willd. Straw sedge. Dry open or partially shaded ground.' Frequent throughout.

Carex festucacea Olney. Fescue sedge. Dry open ground. Frequent throughout.

Carex bebbii Olney. Bebb's sedge. Low open ground, from Bay County to Bois Blanc Island, Mackinac County. Frequent.

Carex aenea Fernald. Wiry sedge. Open sandy ground near Cheboygan, Cheboygan County. Plentiful.

Carex stellulata Good. Little prickly serlge. Open low ground. Frequent throughout.

Carex stellulata cephalantha (Bailey) Fernald. Larger prickly sedge. Marshy open ground. Plentiful throughout.

Carex scirpoides Schkuhr. Inland sedge. Noticed in particular near Alpena and on Mackinac Island. Frequent throughout.

Carex canescens L. Silvery sedge. Wet open or partially shaded ground. Frequent throughout.

Carex bromoides Schkuhr. Brome-like sedge. In swampy places and damp shaded ground. Frequent throughout.

Carex deweyana Schwein. Dewey's sedge. Rich sharled ground. Mostly in rich open woods. Frequent throughout.

Carex tenuiflora Wahlenb. Sparce-flowered sedge. Wet boggy open or partially sharled ground. Frequent throughout.

Carex trisperma Dewey. Three-fruited sedge. Wet boggy ground. Noticed mostly in tamarack-black spruce swamps. Frequent throughout.

Carex tenella Schkuhr. Soft-leaved sedge. Swampy shaded ground especially in damp woods. Frequent throughout.

C'arex rosea Schkuhr. Stellate sedge. Dryish shaded ground and open woods. Frequent throughout.

Carex muhlenbergii Schkuhr. Muhlenberg's sedge. Dry open ground near Pinconning, Bay County. Plentiful.

Carex vulpinoidea Michx. Fox sedge. Low wet open ground. Frequent throughout. 
Carex diandra Schrank. Lesser panicled sedge. Wet marshy or meadow-like ground. Frequent throughout.

Carex stipata Muhl. Awl-fruited sedge. In very wet open or partially shaded ground. Common throughout.

Carex sartuellii Dewey. Sartwell's sedge. In wet marshy open ground from Bay County to Mackinac Island. Plentiful.

Carex crinita Lam. Fringed sedge. Wet open or partially shaded ground. Plentiful throughout.

Carex aquatilis subtricta Kükenthal. Smaller water sedge. On Thunder Bay Island in Alpena County and on Mackinac Island. Tsually in wet marshy open ground. Plentiful throughout.

Carex stricla Iam. Tussock sedge. Very wet usually open ground growing in bunches. Frequent throughout.

Carex aurea Nutt. Golden-fruited sedge. Noticed throughout in open or shaded grassy ground. Plentiful.

Carex hassii Bailey. Hasse's sedge. In damp sand, usually not far from Lake Huron shore, from Sand Point in Huron County to Bois Blanc Island in Mackinac County. Formerly referred to C. bicolor All.

Carex leptalea Wahlenb. Bristle-stalked sedge. Bogs and rery wet mesidow-like ground. Abundant throughout.

C'arex polygama Schkuhr. Brown sedge. Wet marshy places and open logs. Plentiful throughout.

Carex gracillima Schwein. Graceful sedge. Damp open or shaded ground, usually in rich woods. Frequent throughout.

Carex scirpoidea Michx. Scirpus-like sedge: On and near beach of Thumder Bay Island in Alpena County. Plentiful at that place. Not noticed elsewhere.

Carex umbellata Schkuhr. Umble-like sedge. Dry sandy open ground. Aprarently infrequent.

Carex albicans Willd. White-tinged sedge. In open woods about St. Ignace and on Mackinac Island. Plentiful. Not noticed elsewhere.

Carex communis Bailey. Fibrous-rooted sedge. Dryish open woods throughout. Plentiful.

Carex varia Muhl. Emmon's sedge. Dry open ground near Pinconning in Bay County. Plentiful.

Carex pennsylvanica Lam. Pennsylvania sedge. In dry open ground. Frequent throughout.

Carex livida (Wahlenb.) Willd. Livid sedge. Open bogs. Frequent throughout.

Carex tetanica Schkuhr. Wood's sedge. Noticed in damp ground near Linwood in Bay County. Probably growing throughout.

Carex limosa L. Mud sedge. Open bogs, Bois Blane Island, Mackinac County. Plentiful. 
Carex eburnea Boott. Brittle-leaved sedge. On shaded hillsides and bluffs and in dry open or shaded ground. Frequent throughout.

Carex laxiflora patulifolia (Dewey) Carey. Two-edged sedge. Rich shaded ground. Frequent throughout.

Carex laxiflora varians Bailey. Woodland sedge. In open woorls on Mackinac Island. Frequent throughout.

Carex granularis haleana (Olney) Porter. Schriver's selge. In open ground from Bay County to Mackinac Island. Frequent.

Carex crau:ei Dewey. Crawe's sedge. Thunder Bay Island in A! jena County, 1907. Probably to be found throughout.

Carex flava L. Yellow sedge. In wet marshy places throughout. Common.

Carex oederi Retz. Oeder's sedge. In damp sand near Rogers, ('heboygan County. Plentiful in damp sandy open ground near shores.

Carex oederi pumila (Cosson \& Crermain) Fernald. Smaller Oeder's sedge. Damp sandy ground and plentiful on Mackinac Island. F. II. Hunnewell 2d.

Carex castanea Wahlenb. Chestnut sedge. In alluvial woods near Rogers, Presque Isle County. Plentiful. Probably growing throughout.

Carex capillaris L. Hair-like sedge. Open damp ground on Thunder Bay Island in Alpena County and on Mackinac Island, Mackinac County. Plentiful. Often abundant.

Carex capillaris elongata Olney. T'all hair-like sedge. Open or partially shaded ground on Mackinac Island, Mackinac County. Plentiful.

Carex arctata Boott. Drooping wood sedge. In open woods throughout. Plentiful.

Carex debilis rudgei Bailey. Rudge's sedge. Open woods and open meadowlike ground in Arenac County and Alcona County. Plentiful. Probably growing throughout.

Carex filiformis $\mathrm{L}$. Slender sedge. In very wet marshy places. Aburidant throughout.

Carex lanuginosa Michx. Wooly sedge. In wet low open groumel. especially in damp open sand. Plentiful throughout.

Carex oligosperma Michx. Few-seeded sedge. Open boggy grount. Plentiful throughout.

Carex riparia W. Curtis. River bank sedge. Very wet swampy places. Frequent throughout.

Carex pseudo-cyperus. Cyperus-like sedge. In marshy open groumd throughout. Frequent.

Carex comosa Boott. Bristly sedge. Open marshy and swampy ground. Frequent throughout.

Carex hystericina Muhl. Porcupine sedge. Wet open marshy placer. Common throughout.' 
Carex retiorsa Schwein. Retrorse sedge. In marshy open or partially shaded ground. Plentiful throughout.

C"crex intumescens Rudge. Bladder sedge. In swampy, wet woods and meadows. Frequent throughout.

Carex lupulina Muhl. Hop seclge. Open marshy places. Frequent throughout.

Carex rostrata Stokes. Beaked sedge. Very wet open ground. Frequent throughout.

ARACEAE. Arum Family

Arisaema triphyllum (L.) Schott. Jack-in-the-pulpit. Damp rich sharled ground. Common throughout.

Peitandra virginica (L.) Kunth. Green arrow arum. In shallow water urar Bay City, Bay County. Plentiful. G. M. Bradford.

LEMNACEAE. Duckweed Family

Spirodela polyrhiza (I..) Schleid. Greater duckweed. Covering shallow water in pools, ponds and coves throughout. Frequent and often abundant.

Lemma minor L. Lesser duckweed. Covering shallow stagnant water axd often on mud. Common throughout.

ERIOCAULACEAE. Pipewort Family

E'riocaulon articulatum (Huds.) Morong. Seven-angled pipewort. Margin of Long Lake in Cheboygan C'ounty. Plentiful. Apparently infrequent.

XYRIDACEAE. Yellow-eyed Grass Family

Ayris fexuosa Muhl. Slender yellow-eyed grass. In a very wet marshy place near Au Sable, Iosco County. Apparently infrequent.

\section{PONTEDERIACEAE. Pickerel-weed Family}

Pontederia cordata L. Pickerel-weed. In shallow water on borders of small lakes, in large ponds, and coves of streams, from. Bay County to Mackinaw City. Frequent throughout.

Heteranthera dubia (Jacq.) Mac.I. Water star-grass. Shallow water near Bay City, Bay County. G. M. Bradford.

\section{JUNCACEAE. Rush Family}

Juncus bufonius I. Toad rush. Damp open ground. Conmon throughout.

Juncus tenuis Willd. Slender rush. Fields, roadsides, and along paths. Common. 
Juncus dudleyi Wiegand. Dudley's rush. Damp open ground from Bay City, Bay County, to Mackinac Island, Mackinac County. Plentiful.

Juncus balticus littoralis Engelm. Baltic rush. Sandy beachos of Lake Huron and in dry or damp open ground, but soldom abundant. On the sandy beach of Lake Huron it is an efficient sand binder.

Juncus effusus L. Common rush. Low damp open ground. Common throughout.

Juncus brachycephalus (Engelm.) Buchenau. Small-headed rush. Wet marshy places near Bay City in Bay County. Frequent. Probably growing throughout.

Juncus brevicaudatus (Engelm.) Fernald. Narrow panicled-rush. Wet muddy open places. Frequent throughout.

Juncus canadensis J. Gay. Canada rush. Marshy open places. Frequent throughout.

Juncus pelocarpus Mey. Brown-fruited rush. Wr.t sandy open places and damp sandy shores. Frequent throughout.

Juncus nodosus L. Knotted rush. Wet marshy places and in damp sand. Frequent throughout.

Juncus torreyi Coville. Torrey's rush. Damp low sandy ground near Bay City, Bay County. G. M. Bradford.

Juncus alpinus insignis Fries. Richardson's rush. Damp sand on and near Lake Huron beach from Bay City, Bay County to Mackinac Island. Plentiful.

Luzula saltuensis Fernald. Hairy wood-rush. Dryish open wooks throughout. Plentiful.

Luzula campestris mulliflora (Ehrh.) Celak. Common woor-rush. Fields and meadow-like ground. Frequent throughout.

\section{LILIACEAE. Lily Family}

Tofieldia glutinosa (Michx.) Pers. Glutinous tofieldia. In marshy or damp sandy open ground. Plentiful throughout.

Zygadenus chloranthus Richards. Glaucous zygadenus. In damp sandy ground at St. Ignace and on Mackinac Island. Plentiful.

Ivularia grandiflora Sm. Large-flowered bellwort. Rich woods. Frequent throughout.

Oakesia sessilifolia (L.) Watts. Sessile-leaved bellwort. In open woods or open ground. Frequent. Often plentiful.

Allium tricoccum Ait. Wild leek. Pich hardwoods. Plentiful throughout.

Hemerocallis fulva L. Common day lily. A permanent escape throughout in and near cities and villages.

Lilium philadelphicum andinum (Nutt.) Ker. Western red lily. 
Damp rich open or partially shaded ground or in sandy places. Common and often abundant throughout especially along railroads.

Litium superbum L. Turk's-cap lily. Rich open or slightly shaded ground on north side of Bois Blane Island, Mackinac County. Apparently infrequent.

Erythronium americanum Ker. Yellow adder's-tongue. In rich open woods from Bay City, Bay County to Mackinac Island, Mackinac County. Frequent throughout. Often abundant.

Erythronium albidum Nutt. White adder's-tongue. Rich partially shaded ground. From Bay County to Alpena County. Frequent.

Asparagus officinalis L. Garden asparagus. Noticed as a permanent escape near cities and villages throughout.

Clintonia borealis (Ait.) Raf. Yellow clintonia. Moist woods and shaded swampy places. Common throughout.

Smilacina racemosa (L.) Desf. False spikenard. Usually in rich shaded ground. Plentiful throughout.

Smilacina stellata (L.) Desf. Star-flowered Solomon's seal. Equally at home in dry sandy open ground or in rich woods. Common throughout.

Smilacina trifolia (I.) Desf. Three-leaved Solomon's seal. Swampy and boggy ground. Frequent throughout.

Maianthemum canadense Desf. False lily-of-the-valley. Rich shaded ground. Common throughout.

Streptopus amplexifolius (L.) DC. Clasping-leaved twisted-stalk. In damp rich woods on Mackinac Island, Mackinac County, also on Bois Blane Island. F. W. Hunnewell 2d.

Streptopus roseus Michx. Sessile-leaved twisted-stalk. Damp rich woods. Plentiful throughout.

Polygonatum biflorum (Walt.) Ell. Small Solomon's seal. Rich shaded ground. Common throughout.

Medeola virginiana I. Indian cucumber-root. In beech and maple woods near St. Ignace and Rogers. Plentiful. Probably frequent throughout.

Trillium grandiflorum (Michx.) Salisb. Large-flowered wake-robin. In rich shaded ground. Common throughout.

T'rillium cernuum L. Nodding wake-robin. On Thunder Bay Island in Alpena County in rich woods. Probably frequent throughout.

Smilax hispida Muhl. Hispid greenbriar. Rich damp thickets near Au Gres, Arenac County, and in Cheboygan County. Plentiful near Mio, Oscoda County. Apparently infrequent.

\section{AMARYLLIDACEAE. Amaryllis Family}

Hypoxis hirsuta (L.) Coville. Star grass. In damp open ground near Linwood, Bay County. Abundant. 
IRIDACEAE. Iris Family

Iris versicolor L. Larger blue flag. Occasional in low and damp open ground throughout.

Iris lacustris Nutt. Lake dwarf iris. First noticed near Alpena and not far from the Lake Huron shore in damp or dry and open or slightly shaded ground. Very abundant in spots from there to St. Ignace, and on Bois Blanc Island in Mackinac County.

Sisyrinchium augustifolium Mill. Pointed blue-eyed grass. In damp open ground from Bay County to Mackinac Island, Mackinac County. Frequent.

ORCHIDACEAE. Orchis Family

Cypripedium arietinum R. Br. Ram's head lady's slipper. Said to be plentiful in swamps near Huron Beach north of Alpena. Not seen by writer.

Cypripedium parviflorum Salisb. Smaller yellow lady's slipper. In damp rich shaded ground from Bay County to St. Ignace and on Mackinac Island, Mackinac County. Frequent.

Cypripedium parviflorum pubescens( Willd.) Knight. Larger yellow lady's slipper. In rich shaded ground from Bay County to St. Ignace and on Mackinac Island, Mackinac County. Frequent.

Cypripedium hirsutum Mill. Showy lady's slipper. Occasional throughout in damp or wet open or slightly shaded ground. Abundant in spots in Presque Isle and Cheboygan counties.

Cypripedium acaule Ait. Stemless lady's slipper. In shaded sandy ground throughout but seldom abundant.

Orchis spectabilis L. Showy orchis. Rich woods. Occasional throughout.

Habenaria bracteata (Willd.) R. Br. Long bracted orchis. In rich woods from Alpena to St. Ignace and on Mackinae Island, Mackinac County. Frequent.

Habenaria flara (L.) Gray. Tubercled orchis. In wet open or shaded places from Alpena to St. Ignace and on Mackinac Island. Frequent.

Habenaria hyperborea (L.) R. Br. Tall leafy green orchis. In damp woods from Alpena to St. Ignace and on Mackinac Island. Frequent.

Habenaria dilatata (Pursh) Gray. Tall white bog orchis. In very wet open boggy places from Bay City, Bay County, to st. Ignace and on Mackinac Island, Mackinac County. Frequent.

Habenaria clarellata (Michx.) Spreng. Small green wood orchis. Bogs and moist ground. Frequent.

Habenaria obtusata (Pursh) Richards. Small northern bog orchis. Rich woods. Frequent throughout.

Habenaria hookeri Torr. Hooker's orchis. Dry or damp shaded 
ground from Bay County to Mackinac Island, Mackinac County. Frequent.

Habenaria orbiculata (Pursh) Torr. Large round-leaved orchis. Pich shaded ground from Bay County to Mackinac Island, Mackinac County. Apparently infrequent.

Habenaria lacera (Michx.) R. Br. Ragged fringed orchis. In open ground from Bay County to Mackinac Island, Mackinac County. Frequent.

Habenaria psycodes (L.) Sw. Smaller purple-fringed orchis. Wet places and in damp meadow-like ground. Frequent throughout.

Pogonia ophioglossoides (L.) Ker. Rose pogonia. Wet boggy ground. Occasional throughout.

Calopogon pulchellus (Sw.) R. Br. Calopogon. Grass pink. In boggy open ground from Bay County to Mackinaw City, Cheboygan County. Apparently infrequent.

Arethusa bulbosa I. Arethusa. In an open bog near the life saving station above Cheboygan, Cheboygan County. Probably frequent throughout.

Spiranthes gracilis (Bigel) Beck. Slender ladies' tresses. Dry open ground. Occasional throughout. Probably often overlooked.

Spiranthes cernua (L.) Richards. Nodding ladies' tresses. Bogs and damp open ground. Frequent throughout. Abundant in damp open ground at St. Ignace and on Mackinac Island, Mackinac County.

Epipactis repens ophioides (Fernald) A. A. Eaton. Lesser rattlesnake plantain. Rich woods from Alpena, Alpena County to St. Ignace, Mackinac County. Apparently infrequent.

Epipactis tesselata (Lodd.) A. A. Eaton. Checkered rattlesnake plantain. In damp rich woods on Mackinac Island, Mackinac County. Apparently infrequent. The late Prof. C. F. Wheeler noted this plant in Nichigan as early as 1901.

Epipactis decipiens (Hook.) Ames. Menzies' rattlesnake plantain. In rich shaded ground about St. Ignace and on Mackinac Island, Mackinac County. Apparently infrequent.

Listera convallarioides (Sw.) Torr. Broad-lipped twayblade. Damp rich shaded ground on Mackinac Island. Plentiful. Apparently infrequent.

C'orallorrhiza trifida Chatelain. Early coral-root. In rich shaded ground about St. Ignace and abundant on Mackinac Island, Mackinac County. Noticed from Bay County to Mackinac Island.

Corallorrhiza maculata Raf. Large coral-root. Usually in rich shaded ground. Noticed as occasional from Alpena to St. Ignace. Very abundant on Mackinac Island, Mackinac County.

Corallnrrhiza striata Lindl. Striped coral-root. Noticed from near 
Alpena to St. Ignace and on Mackinac Island. Usually in rich shaded ground. Plentiful on Thunder Bay Island, Alpena County.

Microstylis unifolia (Michx.) BSP. Green adder's-mouth. Rich woods near Bay City, Bay County. G. M. Bradford.

Liparis leoselii (L.) Richards. Fen orchis. From Bay County to Mackinac Island, Mackinac County. Frequent.

Calypso bulbosa (I.) Oakes. Calypso. In rich shaded ground on Thunder Bay Island in Alpena County. Apparently infrequent.

SALICACEAE. Willow Family

Salix nigra Marsh. Black willow. Banks of streams and in damp places from Bay County to Mackinaw City, Cheboygan County. Usually small trees or mere shrubs. Plentiful.

Salix nigra falcata (Pursh) Torr. Falcate-leaved black willow. Along small streams near Bay City, Bay County. Frequent. G. M. Bradford.

Salix amygdaloides Anders. Peach-leaved willow. Common from near Linwood, Bay County, through Arenac County. Not noticed farther north. Reported in Michigan Flora as near Harrisville in Alrona County.

Salix lucida Muhl. Shining willow. Wet open ground. Common throughout.

Salix serissima (Bailey) Fernald. Autumn willow. Damp open ground from Bay County to Mackinaw City, Cheboygan County. Occasional throughout.

Salix alba L. White willow. Frequently planted but seldom escaping so far as observed.

Salix longifolia Muhl. Sand bar willow. Noticed as quite frequent on and near the Lake Huron beach from Bay County to Mackinaw City, Cheboygan County.

Salix cordata Muhl. Heart-leaved willow. Along small streams and in damp places with other willows. Frequent throughout.

Salix glaucophylla Bebb. Broad-leaved willow. Noticed as frequent from Arenac County to St. Ignace and on Mackinac Island, Mackinac County. Usually in sandy ground on or near sandy beach of Lake Huron.

Salix syrticola Fernald. Furry willow. On and near the Lake Huron beach from Point Lookout in Arenac County to St. Ignace and on Mackinac Island. Common.

Salix pedicellaris Pursh. Bog willow. In very swampy places from Bay County to Cheboygan, Cheboygan County. Frequent.

Salix discolor Muhl. Glaucous willow. Along streams and in low ground. Frequent throughout.

Salix petiolaris S.m. Slender willow. In wet marshy places from Bay- 
County to St. Ignace and on Mackinac Island, Mackinac County. Plentiful.

Salix humilis Marsh. Prairie willow. In dry sandy ground from Linwood in Bay County to Mackinaw City, Cheboygan County. Common.

Salix sericea Marsh. Silky willow. In wet marshy ground from Bay County to St. Igrace and on Mackinac Island, Mackinac County. Frequent.

Salix rostrata Richards. Bebb's willow. In dry or damp open ground. Frequent throughout.

Salix candida Flügge. Sage willow. In boggy open ground from Bay County to St. Ignace and on Mackinac Island, Mackinac County. Frequent.

Populus alba I. White poplar. Occasionally planted especially in cities and villages and often spreading by root.

Populus tremuloides Michx. American aspen. Common throughout. especially on burnt over ground.

Populus grandidentata Michx. Large-toothed aspen. Common throughout.

Populus balsamifera L. Balsam poplar. Very abundant throughout on and near the Lake Huron shore. Many large trees noticed from Alpena to Mackinaw City, Cheboygan County.

Populus deltoides Marsh. Cotton-wood. Noticed in Bay and Arenac Counties, but not farther north. Plentiful. A sort of horticultural form cultivated as a street and road tree noticed in cities and villages, under common name of "large-leaved poplar" or "Carolina poplar."

Populus nigra italica DuRoi. Lombardy poplar. Planted in cities and occasionally spreading by root.

MYRICACEAE. Sweet Gale Family

Myrica gale L. Sweet gale. In wet open places. Common throughout. Noticed south as far as Sand Point, Huron County. Noticed also in Oakland County by C. Billington.

Myrica asplenifolia L. Sweet fern. Sandy open ground from near Omer in Arenac County to Mackinaw City, Cheboygan County. Abundant on jack pine plains.

\section{JUGLANDACEAE. Walnut Family}

Juglans cincrea L. Butternut. From Bay County to the north line of Alpena County. Frequent. One very large tree and a number of small ones near center of Bois Blanc Island, Mackinac County.

Juglans nigra L. Black walnut. Planted occasionally in cities and 
villages and about farm houses. As a native tree probably not farther north than Tuscola County and the Saginaw valley.

Carya ovata (Mill.) K. Koch. Shag-bark hickory. From near Pincomning in Bay County to the north line of Arenac County. Frequent. Not noticed farther north.

Carya cordiformis (Wang) K. Koch. Bitter-nut. Rich ground with other trees from Pinconning, Bay County, to Alpena County. Frequent.

\section{BETULACEAE. Birch Family}

Corylus americana Walt. Common hazelnut. Pich open ground near Pinconning, Bay County, but not noticed farther north along or near the Lake Huron shore.

Corylus rostrata Ait. Beaked hazelnut. Rich open ground from Bay County to St. Ignace and on Mackinac Island, Mackinac County. Common.

Ostrya virginiana (Mill) K. Koch. Ironwood. In rich woods with other trees from Bay County to St. Ignace and on Mackinac Island, Mackinac County. Plentiful.

Carpinus caroliniana Walt. Blue beech. Noticed only in Bay and Arenac counties, in rich woods with other trees. Frequent.

Betula lutea Michx. f. Yellow birch. Rich ground usually with beech and sugar maple from Bay County to St. Ignace and on Mackinac Island where fine specimens of this species now exist. Betula lenta I., cherry birch, was not noticed.

Betula alba papyrifera (Marsh.) Spach. White birch. Dryish ground with other trees from Bay County to St. Ignace and on Mackinac Island, Mackinac County. Often abundant on burnt-over ground and frequently mingled with beech maple and yellow birch.

Betula pumila L. I.ow birch. In low swampy open ground. Frequent throughout.

Alnus incana (L.) Moench. Speckled alder. In low wet ground from Bay County to St. Ignace and on Mackinac Island, Mackinac County. Abundant.

\section{FAGACEAE. Beech Family}

Fagus grandifolia Ehrh. Beech. With sugar maple and yellow birch forming hardwood forests from Bay County to St. Ignace and on Mackinac Island, Mackinac County. Formerly abundant in spots and streaks, now much reduced by lumbering.

Quercus alba L. White oak. Found from Bay County to a point just south of Harrisville in Alcona County, and not noticed farther north near the Lake Huron shore. Frequent on the Michigan divide. Noticed near Mullet Lake in Cheboygan County, also near Lewiston, Montmorency County, where it is plentiful. 
Quercus macrocarpa Michx. Bur oak. Rich ground with other trees from Bay County to Mackinaw City, Cheboygan County. Seldom plentiful.

Quercus bicolor Willd. Swamp white oak. Rich ground with other trees from Bay County to Bois Blane Island, Mackinac County. Seldom plentiful.

Quercus ellipsoidatis E. J. Hill. Hill's oak. Near Lewiston, Montmorency County. Plentiful.

Quercus rubra L. Red Oak. Fringing the Lake Huron shore more or less from Bay County to Mackinac Island, Mackinac County. Abundant on Mackinac Island and Bois Blanc Island, Mackinac County.

Quercus velutina Lam. Yellow-barked oak. Dry sandy open ground. With other trees from Bay County to Alpena and Montmorency counties. Frequent.

\section{URTICACEAE. Nettle Family}

Ulmus fulva Michx. Slippery elm. Said to be plentiful in Bay County. G. M. Bradford. Reported but not seen near Tawas City in Iosco County. Said to be plentiful in Montmorency County. Noticed near Rose City, Ogemaw County.

Ulmus americana I. American elm. Common from Bay County to Mackinaw City, Cheboygan County. A few large trees on Mackinac Island, Mackinac County. Plentiful and trees large on Bois Blanc Island, Mackinac County.

Ulmus racemosa Thomas. Rock Elm. Rich ground with other trees and plentitul in Preqsue Isle, Montmorency, Oscoda and Ogemaw counties.

Celtis occidentalis I. Sugarberry. At Point Lookout in Arenac County. Perhaps its northern limit. Prof. C. F. Wheeler's notes, dated August 10, 1900. On Little Charity Island in Saginaw Bay.

Cannabis sativa L. Hemp. In and near cities and villages in waste ground. Often plentiful.

Humulus lupulus L. Common hop. Apparently an escape from cultivation near Linwood, Bay County, and about Alpena, Alpena County.

Urtica gracilis Ait. Slender nettle. Damp, open or partially shaded ground from Bay County to St. Ignace, Mackinac County. Seldom abundant.

Laportea canadensis (L.) Gaud. Wood nettle. In rich shaded ground from Bay County to Cheboygan County. Frequent.

SANTALACEAE. Sandalwood Family

Comandra richardsiana Fernald. Richards' bastard toad-flax. In dry open ground from Bay County to St. Ignace and on Mackinac Island, 
Mackinac County. Common and often abundant. C. umbellata (L.) Nutt. Common bastard toad-flax, not noticed.

\section{LORANTHACEAE. Mistletoe Family}

Arceuthobium pusillum Peck. Dwarf mistletoe. On Picca canadensis (Mill.) BSP., white spruce, Bois Blanc Island, Mackinac County. Abundant. Probably throughout, but overlooked.

\section{POLYGONACEAE. Buckwheat Family}

Rumex britannica L. Great water dock. Wet, marshy, usually open ground from Bay County to St. Ignace, Mackinac County. Frequent.

Rumex crispus L. Yellow dock. A weed throughout in cities, village and cultivated fields. Often plentiful in pastures.

Rumex mexicanus Meisn. Willow-leaved dock. Growing in large bunches on and near sandy beach of Lake Michigan west of St. Ignace, also on and near sandy beach, Bois Blanc Island, Mackinac County.

Rumex obtusifolius L. Bitter dock. A weed along roads and near dwellings throughout. Often plentiful in pastures and cultivated grounds.

Rumex acetosella L. Field sorrel. In cultivated grounds. Frequent throughout and often abundant.

Polygonum aviculare L. Knotgrass. About dwellings and in eities and villages. Common.

Polygonum erectum L. Ereet knotweed. Roadsides and streets in and near cities and villages. Frequent throughout.

Polygonum ramosissimum Michx. Bushy knotweed. Sandy beach on Bois Blanc Island, Mackinac County. Plentiful. Not noticed elsewhere.

Polygonum tenue Michx. Slender knotweed. Dry open sandy ground from Bay County to Mackinaw City, Cheboygan County. Frequent.

Polygonum lapathifolium L. Pale persicaria. Wet open places from Bay County to Mackinaw City. Frequent throughout.

Polygonum amphibium I. Water persicaria. About ponds, small lakes, along slow streams, often floating in water. Plentiful.

Polygonum amphibium hartwrightii (Gray) Bissel. Hartwright's persicaria. Damp open ground on Bois Blanc Island, appearing quite distinct. Plentiful in several places.

Polygonum muhlenbergii (Meisn.) Wats. Swamp persicaria. Bay County to St. Ignace, Mackinac County. Plentiful.

Polygonum pennsylvanicum I. Pennsylvania persicaria. Damp open places. Frequent throughout.

Polygonum hydropiper L. Common smartweed. Damp open ground 
from Bay County to St. Ignace, Mackinac County. Frequent. Often abundant.

Polygonum acre HBK. Water smartweed. Damp open ground and along streams. Frequent throughout.

Polyaonum persicaria L. Lady's thumb. Damp places and in waste grounds of cities and villages. Frequent throughout.

Polygonum hydropiperoides Michx. Mild water pepper. Along low banks of streams from Bay County to St. Ignace, Mackinac County. Occasional throughout.

Polygonum virginianum L. Virginia knotweed. Rich shaded ground in Bay and Arenac counties. Plentiful.

Polygonum sagittatum L. Arrow-leaved tear-thumb. Damp open or partially shaded places from Bay County to St. Ignace, Mackinac County. Frequent throughout.

Polygonum convolvulus L. Black bindweed. Noticed as a weed in cities, villages and cultivated grounds generally. Plentiful.

Polygonum cilinode Michx. Fringed black bindweed. Dry open or rocky ground from Bay County to St. Ignace, Mackinac County. Plentiful throughout.

Fagopyrum esculentum Moench. Buckwheat. Occasional about cities and villages and in cultivated grounds. Probably not a permanent escape.

Polygonella articulata (I.) Meisn. Coast jointweed. Noticed in sandy open ground from Bay County to Mackinaw City. Plentiful and often abundant. Common on jack pine plains.

\section{CHENOPODIACEAE. Goosefoot Family}

Chenopodium botrys L. Jerusalem oak. In dry, sandy open ground as a weed. Frequent and often plentiful throughout.

Chenopodium capitatum (L.) Asch. Strawberry blite. Damp or dryish open ground from Bay County to St. Ignace, Mackinac County. Plentiful throughout.

Chenopodium glaucum L. Oak-leaved goosefoot. As a weed in cities and villages. Frequent throughout.

Chenopodium hybridum L. Maple-leaved goosefoot. Dryish open or partially shaded ground from Bay County to St. Ignace, Mackinac County. Plentiful. Often a weed in cultivated grounds.

Chenopodium album I. Pigweed. Lamb's quarters. A common weed in cities, villages and cultivated grounds.

Atriplex patula hastata (L.) Gray. Halberd-leaved orache. Noticed only as a weed in cities and villages. Frequent throughout.

Atriplex patula littoralis (I..) Gray. Shore orache. On and near the sandy beaches of Lake Huron. Occasional throughout. 
Salsola kali tenuifolia G. F. W. Mey. Russian thistle. A weed throughout. Not frequent or troublesome.

AMARANTHACEAE. Amaranth Family

Amaranthus retroflexus I. Amaranth pigweed. Noticed as a weed throughout in cultivated grounds. Frequent.

Amaranthus graecizans L. Tumble-weed. In cultivated ground. throughout. Plentiful.

Amaranthus blitoides Wats. Prostrate amaranth. A weed about cities and villages and in cultivated grounds. Plentiful throughout.

AIZOACEAE. Carpet-weed Family

Mollugo verticillata L. Carpet-weed. In open sandy ground from Bay County to St. Ignace, Mackinac County. Occasional.

\section{CARYOPHYLLACEAE. Pink Family}

Spergula arvensis I. Corn spurry. Sandy open ground. Occasional throughout, in and near cities and villages.

Arenaria serpyllofolia L. Thyme-leaved sandwort. Dry, sandy, open ground. As a weed throughout. Plentiful.

Stellaria longifolia Muhl. Long-stalked stitchwort. In marshy, open ground from Bay County to Mackinaw City. Frequent.

Stellaria graminea L. Lesser stitchwort. Grassy open ground near Pinconning, Bay County. Plentiful at this place.

Stellaria media (L.) Cyrill. Common chickweed. Noticed as a meed in cities, villages and cultivated grounds. Often plentiful.

Cerastium arvense L. Field chickweed. Mackinac Island, Mackinac County. In drvish open ground. Abundant in one place. Not noticed elsewhere.

Cerastium vulgatum L. Common mouse-ear chickweed. Occasional in damp or dryish open ground. As a weed in cities, villages and cultivated grounds. Plentiful.

Agrostemma githago L. Common cockle. Occasional about cities and villages and in waste grounds.

Lychnis alba Mill. White campion. Dry fields and cultivated grounds, and about cities and villages. Frequent.

Silene antirrhina L. Sleepy catchfly. In dry and sandy open ground from Bay County to St. Ignace, Mackinac County. Frequent.

Silene noctiflora L. Night-flowering catchfly. About cities and rillages, and in waste places as a weed. Frequent.

Silene latifolia (Mill.) Britten \& Rendle. Bladder campion. A- is weed in waste places of cities and villages. Occasional throughout. 
Saponaria officinalis L. Bouncing bet. In sandy open ground from Bay County to Mackinaw City. Frequent and often plentiful.

Gypsophila muralis L. Low gypsophyll. Well established in an old field at Misery Bay near Alpena. Plentiful.

Gypsophila elegans Bieb. Elegant gypsophila. Apparently a permanent escape from cultivation in and about the village of Mackinac Island, Mackinac County. Plentiful.

\section{PORTULACACEAE. Purslane Family}

Claytonia virginica L. Spring beauty. Rich shaded ground from Bay County to St. Ignace, Mackinac County. Frequent.

Claytonia caroliniana Michx. Carolina spring beauty. In slightly shaded ground on Mackinac Island, and Bois Blanc Island, Mackinac County. Plentiful. Not noticed farther south.

Portulaca oleracea L. Common purslane. Occasional as a weed in cities, villages, cultivated grounds and waste places.

\section{NYMPHAEACEAE. Water Lily Family}

Nymphaea advena Ait. Yellow water lily. More or less frequent in small lakes, ponds and coves of streams from Bay County to St Ignace, Mackinac County.

Castalia odorata (Ait.) Woodville \& Wood. Sweet-scented water lily. Ponds, small lakes, borders of slow streams and coves from Alpena to St. Ignace, Mackinac County. Plentiful.

Castalia tuberosa (Paine) Greene. White water lily. In small lakes, ponds, and coves of streams from Bay County to St. Ignace, Mackinac County. Plentiful.

Brasenia shreberi Gmel. Water shield. In shallow water of small lakes and coves of streams from Bay County to Mackinaw City, Cheboygan county. Plentiful.

\section{RANUNCULACEAE. Crowfoot Family}

Ranunculus circinatus Sibth. Stiff water crowfoot. In shallow stagnant water from Bay County to St. Ignace, Mackinac County. Often abundant.

Ranunculus delphinifolius Torr. Yellow water crowfoot. In ponds, ditches and stagnant water from Bay County to St. Ignace, Mackinac County. Often abundant.

Ranunculus flammula filiformis (Michx.) Hook. Smalier creeping spearwort. Near life saving station above Rogers on the low sandy beach of Lake Huron. Probably frequent on sandy and gravelly shores throughout but overlooked.

Ranunculus sceleratus L. Cursed crowfoot. In very wet open places 
from Bay County to St. Ignace and on Mackinac Island, Mackinac County. Plentiful.

Ranunculus abortivus L. Smaller-flowered crowfoot. In damp open or shaded ground from Bay County to St. Ignace and on Mackinac Island, Mackinac County. Common and often abundant.

Ranunculus recurvatus Poir. Hooked crowfoot. In damp open or partially shaded ground throughout. Frequent.

Ranunculus septentrionalis Poir. Swamp buttercup. In damp open or shaded ground. Frequent throughout.

Ranunculus bulbosus L. Bulbous erowfoot. In clry open ground near Bay City, Bay County. Plentiful. G. M. Bradford.

Ranunculus acris L. Tall crowfoot. From Bay County to St. Ignace in Mackinac County. Plentiful. From Harrisville to St. Ignace and on Mackinac Island, it is a pernicious weed, covering pastures and cultivated grounds, even penetrating woods and thickets.

Ranunculus pennsylvanicus L.f. Bristly crowfoot. Damp open ground. Frequent throughout.

Thatictrum dioicum L. Early meadow rue. In damp woods and thickets from Bay County to St. Ignace, Mackinac County. Plentiful.

Thalictrum dasycarpum Fisch. \& Lall. Purplish meadow rue. From Bay County throughout in open or shaded ground. Plentiful.

Hepatica triloba Chaix. Round-lobed liver-leaf. In dryish open or shaded ground. Frequent throughout.

Hepatica acutiloba DC. Sharp-lobed liver-leaf. In beech-maple woods from Bay County to St. Ignace, Mackinac County. Frequent.

Anemone multifida Poir. Red wind-flower. First noticed in sandy open ground near Alpena and it is frequent from there to St. Ignace, Mackinas County, on or near the sandy beach of Lake Huron.

Anemone cylindrica Gray. Long-fruited anemone. In dry open or partially shaded sandy ground from Bay County to Alpena. Plentiful. Common on jack pine plains.

Anemone virginiana L. Tall anemone. In dryish open or slightly shaded ground throughout. Plentiful.

Anemone canadensis I. Canada anemone. In damp or dryish open or partially shaded ground from Bay County to St. Ignace, Mackinac County. Plentiful.

Anemone quinquefolia L. Wood anemone. Rich partially shaded ground from Bay County to St. Ignace, Mackinac County.

Clematis virginiana L. Virginia virgin's bower. Borders of rich woods, damp thickets and along streams. Plentiful throughout.

Caltha palustris L. Marsh marigold. In very wet open or shaded places. Abundant throughout.

Coptis trifolia (L.) Salisb. Goldthread. In swampy or damp open or shaded ground. Common throughout. 
Aquilegia canadensis I. Wild columbine. In sandy or rocky open or partially shaded ground throughout. Plentiful.

Aquilegia vulgaris L. Garden columbine. Apparently permanently established on the gravelly beach of Mackinac Island, Mackinac County.

Actaea rubra (Ait.) Willd. Red baneberry. In damp rich open woods. Frequent throughout.

Actaea rubra forma neglecta (Gillman) Robinson. Gillman's baneberry. Noticed as frequent on Mackinac Island and in other places. Pedicels capillary, berries white.

Actaea alba (L.) Mill. White baneberry. In dryish rich open woods. Plentiful throughout.

Hydrastis canadensis L. Golden seal. Reported as occasional in rich woods throughout but not noticed by the writer.

\section{BERBERIDACEAE. Barberry Family}

Caulophyllum thalictroides (L.) Michx. Papoose root. Rich open woods. Occasional throughout.

Berberis vulgaris L. Common Barberry. Cultivated as an ornamental shrub in cities and villages but not noticed as escaping.

\section{PAPAVERACEAE. Poppy Family}

Sanguinaria canaderisis L. Bloodroot. Open rich woods from Bay County to St. Ignace, Mackinac County. Plentiful.

\section{FUMARIACEAE. Fumitory Family}

Adlumia fungosa (Ait.) Greene. Climbing fumatory. Damp shaded ground from Bar County to St. Ignace, Mackinac County. Infrequent.

Dicentra cucullaria (L.) Bernh. Dutchman's breeches. Rich shaded ground throughout. Frequent.

Dicentra canadensis (Goldie) Walp. Squirrel corn. Rich woods from Bay County to St. Ignace. Frequent.

Corydalis sempervirens (L.) Pers. Pale corydalis. Dry open ground from Bay County to St. Ignace. Often abundant on burned over areas.

Corydalis aurea Willd. Golden corydalis. Near Alpena, Alpena County, in open sandy ground. Apparently rare.

\section{CRUCIFERAE. Mustard Family}

Draba arabisans Michx. Twisted whitlow-grass. On rocky bluff east side of Mackinac Island. Abundant. Not noticed elsewhere.

Alyssum alyssoides I. Yellow alyssum. In dry open ground about cities and villages. Often plentiful.

Thlaspi arvense L. Field penny cress. From Bay County to St. Ignace, Mackinac County, in cities and villages. Infrequent. 
Lepidium virginicum I. Wild peppergrass. In cities, villages and cultivated grounds as a weed. Seldom abundant.

Lepidium apetalum Willd. Apetalous peppergrass. A weed in cities and rillages throughout but apparently infrequent.

Capsella bursa-pastoris (L.) Medic. Shepherd's purse. Cultivated grounds and waste places. Common.

Camelina sativa (L.) Crantz. False flax. About cities and villages and along railroads as a weed. Infrequent.

Cakile edentula (Bigel.) Hook. American sca rocket. On and near sandy beach of Lake Huron throughout. Seldom abundant.

Brassica arvensis (L.) Ktze. Common mustard. About cities and villages and in cultivated grounds as a weed, but not noticed as abundant anywhere.

Brassica nigra (L.) Koch. Black mustard. Noticed as a weed about cities and villages. Infrequent.

Brassica campestris L. Rutabaga. Occasional as a temporary escape about cities and villages and along railways.

Conringia orientalis (L.) Dumont. Hare's-ear mustard. Apparently well established about cottages and in cultivated grounds on Bois Blane Island, Mackinac County.

Sisymbrium officinale leiocarpum DC. Smooth podded hedge mustard. About cities and villages and in cultivated grounds. Infrequent.

Sisymbrium altissimum I. Tumble mustard. About depot grounds in cities and villages, and in waste places. Frequent.

Braya humilis (C. A. Mey.) Robinson. Low rock cress. On Mackinace Island. G. H. Hicks. Not noticed in 1912.

Erysimum cheiranthoides I. Worm-seed mustard. About cities and villages and in waste places as a weed throughout, but infrequent.

Radicula nasturtium-aquaticum (L.) Britten \& Rendel. True watel cress. In ditches, small creeks and ahout springs throughout. Often plentiful.

Radicula palustris (L.) Moench. Marsh eress. In wet open ground from Bay County to St. Ignace, Mackinac County. Plentiful, often abundant.

Radicula palustris hispida (Desv.) Robinson. Hispid yellow cress. Wet open ground throughout. Infrequent.

Radicula armoracia (L.) Robinson. Horseradish. Frequent in damp, places about cities and villages. Noticerl in particular as a well estahlished escape in an old field at Misery Bay near Alpena, Alpena County.

Barbarea vulgaris R.Br. Common winter eresș. Low open ground. Frequent throughout. Abundant in spots in Cheborgan County and on Mackinac Island, Mackinac County.

Dentaria diphylla Michx. Two-leaved toothwort. In rich shaded 
ground throughout. Noticed in particular near St. Ignace and on Mackinac Island.

Dentaria laciniata Muhl. Cut-leaved toothwort. Rich damp shaded ground. Occasional throughout. Probably often overlooked.

Cardamine bulbosa (Schreb.) BSP. Spring cress. Wet meadow-like ground or in damp and springy places. In Bay and Arenac Counties. Perhaps throughout but overlooked.

Cardamine douglassii (Torr.) Britton. Purple cress. Rich damp shaded ground. In Bay and Arenac counties. Frequent.

Cardamine pennsylvanica Muhl. Pennsylvania bitter-cress. Wet springy ground, and along creeks throughout. Infrequent.

Arabis lyrata L. Lyre-leaved rock-cress. Dry sandy open ground, usualiy on or near sandy beach of Lake Huron. Frequent throughout.

A rabis glabra (L.) Bernh. Tower mustard. Dry open or partially shaded ground. Frequent throughout.

Arabis drummondi Gray. Drummond's rock-cress. Dry open ground on Mackinac Island, Mackinac County, and also near Harrisville, Alcona County. Probably to be found throughout.

Arabis holboellii Hornem. Holboell's rock-cress. Dry sandy open ground near Alpena and on sandy beach at Mackinaw City. Frequent.

CAPPARIDACEAE. Caper Family

Polanisia graveolens Raf. Clammy-weed. Sandy open ground at Bay City. G. M. Bradford.

SARRACENIACEAE. Pitcher-plant Family

Sarracenia purpurea L. Pitcher plant. Swampy ground and often abundant in damp sand. Common throughout.

\section{DROSERACEAE. Sundew Family}

Drosera rotundifolia L. Round-leaved sundew. Open swampy ground or in damp sand. Frequent throughout.

Drosera longifolia L. Oblong-leaved sundew. In bogs near Alpena. Plentiful. H. H. Hindshaw.

Drosera linearis Goldie. Slender-leaved sundew. Wet boggy places on Bois Blanc Island, Mackinac County. Plentiful.

CRASSAULACEAE. Orpine Family

Penthorum sedoides L. Ditch stonecrop. Open swampy ground from Bay County to St. Ignace, Mackinac County. Plentiful.

Sedum acre L. Mossy stonecrop. In dry sandy open ground along roads, in cemeteries, cities and villages. Often abundant.

Sedum purpureum Tausch. Live-for-ever. Along roads, near cities and villages. Frequent throughout. Seldom blooming. 


\section{SAXIFRAGACEAE. Saxifrage Family}

Tiarella cordifolia L. False miterwort. In rich shaded ground from Bay County to St. Ignace, Mackinac County. Frequent.

Mitella diphylla L. Two-leaved bishop's cap. In rich damp woorls throughout. Frequent.

Mitella nuda L. Naked bishop's cap. In damp shaded ground. Plentiful throughout.

Chrysosplenium americanum Schwein. Golden saxifrage. Wet, usually shaded places. Frequent throughout.

Parnassia parviflora DC. Small-flowered grass-of-parnassus. In marshy open ground on Mackinac Island. F. W. Hunnewell 2 nd. Apparently infrequent.

Parnassia caroliniana Michx. Carolina grass-of-parnassus. Common throughout in low marshy open ground.

Ribes cynosbati L. Prickly gooseberry. In damp open or sharled ground. Frequent from Bay County to St. Ignace, Mackinac County.

Ribes gracile Michx. Missouri gooseberry. In rich shaded ground from Bay County to Mackinaw City, Cheboygan County. Frequent.

Ribes oxyacanthoides L. Smooth gooseberry. Damp open or partially shaded ground. Frequent throughout.

Ribes oxyacanthoides calcicola Fernald. Low wild gooseberry. In shaded ground on Mackinac Island. F. W. Hunnewell 2nd. Common. Ribes floridum. L'Her. Wild black currant. Pich shaded ground. Common throughout.

Ribes lacustre (Pers.) Poir. Swamp black currant. Common in damp shaded ground from Alpena to St. Ignace and on Mackinac Island.

Ribes prostratum L'Her. Skunk currant. In damp open or shaded ground from Alpena to St. Ignace and on Mackinac Island. Plentiful.

Ribes triste Pall. Swamp red currant. Rich damp woods throughout. Plentiful.

Ribes triste albinervium (Michx.) Fernald. Glabrous swamy red ecrrant. Rich woods on Bois Blanc Island, Mackinac County. Plentiful.

Ribes aureum Pursh. Missouri currant. Cultivated but apparently not escaping.

\section{HAMAMELIDACEAE. Witch-hazel Family}

Hamamelis virginiana L. Witch-hazel. Dry open ground or often in slight shade of other trees. Frequent throughout. Common near Lewiston, Montmorency County.

\section{ROSACEAE. Rose Family}

Physocarpus opulifolius (L.) Maxim. Nine-bark. Low open ground or along banks of streams. Frequent throughout. 
Spiraea salicifolia L. 'Meadow-sweet. In damp open or slightly shaded ground. Common throughout.

Sorbaria sorbifolia (L.) A.Br. Ash-leaved spiraea. Cultivated throughout but apparently not spreading.

Pyrus malus L. Common apple. In open ground on borders of woods and about cities and villages. Plentiful throughout. Abundant on Thunder Bay Island, Alpena County, where it seems to be stunted, shrubs two feet high and spreading being in full bloom June 25, 1907.

Pyrus arbutifolia atropurpurea (Britton) Robinson. Purple-fruited chokeberry. In very wet places and swamps. Frequent throughout.

Pyrus melanocarpa (Michx.) Willd. Black chokeberry. In moist or dryish open ground from Bay County to St. Ignace, Mackinac County. Plentiful.

Pyrus americana Marsh. Americana mountain ash. First noticed near Black River in Alcona County. Occasional from there to Mackinaw City, Cheboygan County. Apparently variable and approaching Sorbus americana decora Sarg. See Manual of the Trees of North America, by Prof. C. S. Sargent, page 357.

Pyrus sitchensis (Roem.) Piper. Western mountain ash. West side of Mackinac Island, Mackinac County. Forms approaching this species noticed as far south as Alpena.

Amelanchier sanguinea (Pursh) DC. Low juneberry. Open dry or damp ground and along streams. Frequent throughout. See Rhodora, Vol. 14-138.

Amelanchier florida Lindley. Round-leaved juneberry. Sandy open ground near Alpena, Alpena County. Plentiful. See Rhodora, Vol. 14-143.

Amelanchier canadensis (L.) Medicus. Common juneberry. Dryish ground. Common throughout.

Crataegus punctata Jacq. Large-fruited thorn. In open ground or woods throughout. Plentiful.

Crataegus douglasii Iindl. (C. brockwayae Sarg.) Douglas' thorn. On Bois Blanc Island. Apparently infrequent. Dryish open or partially shaded ground.

Fragaria virginiana Duchesne. Common strawberry. This and the following species were noticed in particular as very abundant, rank, thrifty, and producing fruit in great abundance from Alpena to Mackinaw City.

Fragaria vesca americana Porter. American wood strawberry. Very common throughout in damp open or shaded ground.

Waldsteinia fiagarioides (Michx.) Trattinick. Barren strawberry. Usually in shaded ground and noticed from Bay County to Mackinac Island, Mackinac County. Frequent. 
Potentilla monspeliensis L. Rough cinquefoil. About cities and rillages and in cultivated grounds. Frequent.

Potentilla argentea L. Silvery cinquefoil. In dry open ground throughout and often abundant.

Potentilla palustris (L.) Scop. Marsh five-finger. Wet swampy ground throughout. Common.

Potentilla fruticosa L. Shrubby cinquefoil. In damp open ground throughout. Frequent.

Potentilla tridentata Ait. Three-toothed cinquefoil. Abundant in a dry old field near Oscoda, Iosco County. Not noticed elsewhere. Very probably overlooked.

Potentilla anserina L. Silver weed. In dry sandy open ground usually on or near the sandy beach of Lake Huron. Noticed as a bad field weed near Alpena.

Potentilla canadensis L. Five-finger. In dry open ground from Bay County to St. Ignace, Mackinac County. Frequent.

Geum canadense Jacq. White avens. In rich open woods throughout. Plentiful.

Geum virginianum I. Rough avens. Damp open ground in Alpena and Presque Isle counties. Apparently infrequent.

Geum strictum Ait. Yellow avens. In damp meadow-like ground. Plentiful throughout.

Geum rirale L. Water arens. Damp open or rich shaded ground. Frequent throughout.

Rubus idaeus aculeatissimus (C.A.Mey.) Regal \& Tiling. Wild red raspberry. Common throughout in dry open or shaded ground.

Rubus occidentalis 1. Black raspberry. In damp rich shaded ground from Bay County to Mackinaw City. Plentiful. Also near Rose City, Ogemaw County.

Rubus odoratus L. Purple-flowering raspberry. First noticed near Alpenat and from there quite frequent to a short distance north west of Rogers where the next species apparently takes its place. For sereral miles the two species intermingle. Probably frequent from Bay County to Presque Isle County. Southern limit on east side of Michigan appears to be near Port Huron, St. Clair County.

Rubus partiflorus Nutt. Salmon berry. First noticed a few miles northwest of Rogers in Presque Isle County. Within a few miles the change from the preceding to this species is quite complete. Here it is a vigorous shrub with pure white flowers often over two inches in diameter. Common from this point to St. Ignace and on Mackinac Islancl, Nackinac County.

Rubus triflorus lichards. Dwarf raspberry. In wet shaded ground. Common throughout. 
Rubus allegheniensis Porter. High bush blackberry. In dry open or slightly shaded ground. Frequent throughout.

Rubus pergratus Blanchard. Red stemmed raspberry. Open places in beech-maple woods on Mackinac Island. Plentiful. By F. F. Forbes. See North American Flora Vol. 22, 467.

Rubus hispilus L. Hispid blackberry. In dryish or swampy open or shaded ground from Bay County to St. Ignace, Mackinac County. Frequent.

Rubus villosus Ait. Dewberry. In dry open ground from Bay County to St. Ignace, Mackinac County. Frequent. (Formerly under name of R. canadensis.)

Agrimonia gryposepala Wallr. Tall hairy agrimony. In dryish open or shaded ground from Bay City to St. Ignace, Mackinac County. Frequent. Also near Mio, Oscodla County.

Rosa acicularis Lindl. Prickly rose. First noticed a few miles north of Harrisville in Alcona County. Common from there and often abundant in dryish open or slightly shaded ground to St. Ignace and on Mackinac Island.

Rosa blanda Ait. Meadow rose. In dry open or slightly shaded ground. Plentiful. Very frequently abundant on the sandy beach of lake Huron and acting as a sand binder. From a short distance north of Harrisville to Mackinac Island it grows with the preceding species.

Rosa spinosissima L. Scotch rose. Noticed in Bay County as an escape from cultivation. Apparently infrequent.

Rosa rubiginosa L. Sweetbriar. Near cities and villages from Bay County to St. Ignace and on Mackinac Island. Plentiful.

Rosa carolina L. Swamp rose. In wet open ground especially on low l,anks of small streams. Frequent throughout.

Prunus serotina Ehrh. Wild black cherry. In rich woods with other trees from Bay County to St. Ignace. Frequent.

Prunus virginiana L. Choke cherry. Damp or dry ground on borders of woods or near sandy beaches of Lake Huron. Common throughout.

Prunus pennsylvanica I.f. Wild red cherry. Dry open ground with other trees. Often abundant on burnt over lands. Noticed throughout.

Prunus cuneata Raf. Appalachian cherry. Damp open ground above Au Gres, Arenac County. Common on jack pine plains.

Prunus pumila L. Sand cherry. On and near sandy beach of Lake Huron from Bay County to St. Ignace, Mackinac County. Abundant.

I'runus cerasus L. Common garden cherry. Occasional as an escape in cities and villages throughout.

LEGUMINOSAE. Pulse Family

Lupinus perennis L. Wild lupine. Sandy open ground near Pinconning in Bay County. Apparently infrequent. Perhaps overlooked. 
Trifolium pratense L. Red clover. Growing everywhere like a native plant. From Rogers to Mackinaw City it thrives and is rank on sandy ground and in open woods far from cultivated grounds.

Trifolium repens $\mathrm{L}$. White clover. In fields, pastures and along roads. Plentiful. From Rogers to Mackinaw (ity it grows very large and rank even on sandy ground and in open woods and thickets far from cultivated land.

Trifolium hybridum L. Alsike clover. About cities and villages. Plentiful from Rogers to Mackinaw City. This also looks thrifty. The region between these cities seems to be naturally adapted to the clovers.

Melilotus officinalis (J.) Lam. Yeilow melilot. About cities and villages. Occasional.

Melılotus alba Desr. Sweet clover. In cities and villages. Frequent from Bay County to Alpena.

Medicago sativa L. Alfalfa. Occasional about cities and villages from Bay County to Mackinac Island, Mackinac County.

Medicago lupulina I. Black medic. About cities and villages and in waste places. Frequent.

Robinia pseudo-acacia L. Common locust. Planted but not escaping in cities and villages.

Lespedeza capitata Michx. Round-headed bush-clover. In dry open ground, Bay County. Apjarently infrequent.

I'icia angustifolia (L.) Reichard. Smaller common vetch. Near Pinconning in Bay County. Apparently infrequent.

Vicia cracca L. Tufted vetch. On Mackinac Island. Apparently infrequent.

I'icia villosa Roth. Hairy vetch. In waste places near Pinconning in Bay County.

Lathyrus maritimus (L.) Bigel. Beach pea. Common on sandy beach of Lake Huron from Au Gres in Arenac County to St. Ignace and on Mackinac Island, Mackinac County.

Lathyrus palustris L. Marsh vetchling. In marshy open ground throughout. Plentiful.

Lathyrus palustris linearifolius Ser. Winged marsh vetchling. Near Lake Huron shore and on margins of woods from Bay County to Mackinac Island, Mackinac County. Plentiful.

Lathyrus ochroleucus Hook. Cream-colored retchling. In open dryish woods from Bay County to St. Ignace. Frequent.

\section{LINACEAE. Flax Family}

Linum usitatissimum J. Common flax. Along the railroads in Bay County and about cities and villages to St. Ignace, Mackinac County. 
OXALIDACEAE. Wood sorrel Family

Oxalis corniculata L. Lady's sorrel. About cities and villages appearing as if introduced. Apparently infrequent.

\section{GERANIACEAE. Geranium Family}

Geranium maculatum L. Wild cranesbill. In open woods and thickets throughout. Plentiful.

Geranium robertianum L. Herb robert. In damp shaded ground from Alpena to St. Ignace, Mackinac County. Abundant in spots on Mackinac Island.

Geranium bicknellii Britton. Bicknell's cranesbill. Open or partially shaded ground from Arenac County to St. Ignace, Mackinac County. Often very abundant on low recently burnt over ground.

\section{RUTACEAE. Rue Family}

Zanthoxylum americanum Mill. Northern prickly ash. Near Pinconning in Bay County and Standish, Arenac County. Plentiful. Also on Bois Blanc Island, Mackinac County. Common about Hillman, Montmorency County, and Mio, Oscoda County.

SIMARUBACEAE. Quassia Family

Ailanthus glandulosa Desf. Ailanth!s. Tree of hearen. Cultivated some as an ornamental tree in cities throughout, but apparently not permanently escaping.

\section{POLYGALACEAE. Milkwort Family}

Polygala panciflora Willd. Fringed polygala. In dry shaded ground from Bay County to Mackinac Island, Mackinac County. Plentiful.

Polygala polygama Walt. Pacemed milkwort. Dry open sandy ground throughout. Frequent. Common on jack pine plains in Montmorency, Oscoda and Ogemaw counties.

Polygala senega L. Seneca snakeroot. Dryish open or partially shaded ground in Bay and Alpena counties. Apparently infrequent.

\section{EUPHORBIACEAE. Spurge Family}

Euphorbia polygonifotia L. Seaside Spurge. Orcasional on the sandy beach of Lake Huron from Arenac County to Mackinaw City, Cheboygan County. Often in drifting sand.

Euphorbia maculata L. Milk purslane. Dry open ground about cities and villages, appearing as if introduced.

Euphorbia helioscopia L. Wartweed. At St. Ignace and on Mackinac 
Island, Mackinac County. Plentiful. Perhans throughout but overlooked.

Euphorbia cyparissias L. Cypress spurge. Along roads, about cities and villages, and in cemeteries. In spots abundant throughout.

\section{ANACARDIACEAE. Cashew Family}

Rhus typhina L. Staghorn sumach. Dryish open ground on borders of woods. Frequent throughout.

Rhus glabra L. Smooth sumach. Dry open ground from Bay County to St. Ignace, Mackinac County. Plentiful.

Rhus toxicodendron L. Poison ivy. In dry or damp open or shaded ground. Common along and near the sandy beach of Lake Huron.

\section{AQUIFOLIACEAE. Holly Family}

Ilex verticillata (L.) Gray. Winterberry. Low open ground from Bay County to Mackinaw City, Cheboygan County. Frequent.

Nemopanthus mucronata (I.) Trel. Mountain holly. Damp places with other shrubs from Bay County to St. Ignace, Mackinac County. Plentiful.

\section{CELASTRACEAE. Staff Tree Family}

Celastrus scandens L. Bittersweet. In woods and thickets. Common throughout.

\section{ACERACEAE. Maple Family}

Acer pennsylvanicum L. Striped maple. First noticed in a small piece of timber about two miles north of Harrisville in Alcona County. Common in woods with other trees from that point to St. Ignace and on Mackinac Island.

Acer spicatum Lam. Mountain maple. Damp woods and thickets. Abundant throughout.

Acer saccharum Marsh. Sugar maple. Rich ground. One of the principal trees forming hardwoods and common throughout. Formerly very abundant.

Acer saccharinum I. Silver maple. Cultivated as an ornamental tree in cities and villages but not noticed as escaping.

Acer rubrum L. Red maple. Usually in damp rich ground with other trees. Plentiful from Bay County to St. Ignace, Mackinac County.

Acer negundo L. Box elder. Cultivated as an ornamental tree in cities and villages but apparently not spreading.

\section{SAPINDACEAE. Soapberry Family}

Aesculus hippocastanum I. Common horse-chestnut. Cultivated as an ornamental street tree in cities and villages throughout, but apparently not spreading. 
BALSAMINACEAE. Touch-me-not Family

Impatiens biflora Walt. Spotted touch-me-not. Damp open or partially shaded ground. Abundant throughout.

RHAMNACEAE. Buckthorn Family

Rhamnus alnifolia L'Her. Alder-leaved buckthorn. Damp open or shaded ground. Plentiful throughout.

Ceanothus americanus L. New Jersey tea. Dry open ground near Onaway, Presque Isle County. Apparently infrequent.

Ceanothus ovatus Desf. Smaller red-root. Dry open ground from Bay County to Mackinaw City. Frequent throughout.

\section{VITACEAE. Vine Family}

Psedera vitacea (Knerr) Greene. American woodbine. Damp shaded ground from Bay County to St. Ignace, Mackinac County. Frequent throughout. Noticed also near Lewiston, Montmorency County.

Titis vulpina I. River-bank grape. From Bay County to Round Island and Bois Blanc Island, Mackinac County. Frequent. Noticed as frequent in Montmorency, Oscoda and Ogemaw counties.

\section{TILIACEAE. Linden Family}

Titia americana L. Basswood. Rich ground with other trees, especially in hardwoods. Frequent throughout. Trees often very large.

MALVACEAE. Mallow Family

Malva rotundifolia L. Common mallow. About dwellings and in cities and villages. Common throughout.

Malva moschata L. Musk mallow. Noticed along roads and in old fields, Presque Isle County. Occasional throughout.

\section{HYPERICACEAE. St. John's-wort Family}

Hypericum ascyron L. Great St. John's-wort. Damp places and banks of streams throughout. Infrequent.

Hypericum perforatum L. Common St. John's-wort. In fields and pastures and along roads. Frequent throughout.

Hypericum kalmianum L. Kalm's St. John's-wort. Usually in dry sandy ground on and near the sandy shores of Lake Huron. Frequent throughout.

Hypericum virginicum L. Narsh St. John's-wort. Open marshy ground throughout. Frequent. 
CISTACEAE. Rockrose Family

Helianthemum canadense (L.?) Michx. Common frostweed. In sandy open ground from Bay County to St. Ignace, Mackinac County. Frequent throughout.

Hudsonia tomentosa Nutt. False heather. Noticed from above Au Gres in Arenac County to St. Ignace, Mackinac County. In spots very abundant, often covering open or shaded sandy ground on or near sandy beaches of Lake Huron.

Lechea intermedia Leggett. Large-podded pinweed. Dry sandy open ground. Frequent throughout. Also near Mio, Oscoda County.

\section{VIOLACEAE. Violet Family}

Viola cucullata Ait. Marsh blue violet. In very wet marshy open places throughout. Plentiful.

Viola nephrophylla Greene. Small mottled blue violet. In damp, open or shaded ground. Plentiful throughout.

Viola lanceolata L. Lance-leaved violet. In damp open ground from Bay County to St. Ignace, Mackinac County. Plentiful.

Viola pallens (Banks) Brainard. Northern white violet. Wet, springy open or partially shaded ground. Frequent throughout.

Viola blanda Wild. Sweet white violet. Moist rich shaded ground from Bay County to St. Ignace, Mackinac County. Frequent throughout.

Viola incognita Brainard. Large-leaved white violet. In rich woods from Bay County to St. Ignace, Mackinac County. Plentiful.

Viola renifolia Gray. Kidney-leaved violet. Rich shaded ground throughout. Plentiful. A form such as is noticed on Mackinac Island, Mackinac County, has been naned $V$. renifolia brainerdii Fernald, Brainerd's sweet violet. It is abundant north.

Viola pubescens Ait. Downy vellow violet. Dryish sandy shaded ground from Bay County to Bois Blanc Island, Mackinac County. Frequent.

Viola scabriuscula Schwein. Smooth yellow violet. In damp rich shaded ground throughout. Plentiful.

Viola canadensis I. Canada violet. In rich shaded ground from Bay County to St. Ignace, Mackinac County. Plentiful.

Viola conspersa Reichenb. American dog violet. In rich shaded ground from Bay County to St. Ignace, Mackinac County. Plentiful, often abundant.

Viola arenaria DC. Sand violet. Sandy sterile open ground from Bay County to Mackinaw City, Cheboygan County. Frequent. 
CACTACEAE. Cactus Family

Opuntia rafinesquii Engelm. Western prickly pear. Reported west of Alpena, Alpena County, in open sandy ground. Not seen by writer.

\section{THYMELAEACEAE. Mezereum Family}

Dirca palustris L. Moose-wood. Leather-wood. Rich oper woods. Frequent. Noticed in particular near Presque Isle Bay in Presque Isle County.

\section{ELAEAGNACEAE. Oleaster Family}

Shepherdia canadensis (L.) Nutt. Canadian buffalo-berry. In dry open or partially shaded ground. Frequent throughout.

\section{ONAGRACEAE. Evening Primrose Family}

Ludvigia polycarpa Short \& Peter. Nany-fruited ludvigia. Wet open places in Bay County. Plentiful.

Ludvigia palustris Walt. Water purslane. Ditches and very wet places throughout. Often abundant.

Epilobium angustifolium $\mathrm{L}$. Great willow-herb. Fireweed. In dryish open or shaded ground, being very abundant throughout on burnt orer land.

Epilobium molle Torr. Downy willow-herb. In marshy or boggy ground from Bay County to Mackinaw City, Cheboygan County. Frequent.

Epilobium densum Raf. Linear-leaved willow-herb. Low marshy open ground. Frequent throughout.

Epilobium adenocaulon Haussk. Northern willow-herb. In damp open ground from Bay County to St. Ignace. Plentiful.

Oenothera biennis L. Common evening primrose. In dry open or sharled ground throughout. Often abundant on and near the sandy beach of Lake Huron.

Circaea lutetiana L. Enchanter's nightshade. Beech-maple woods throughout. Frequent. Often plentiful.

Circuea alpina L. Smaller enchanter's nightshade. In damp woods throughout. Common. Often abundant.

\section{HALORAGIDACEAE. Water Milfoil Family}

Myriophyllum spicatum L. Spikerl water milfoil. In shallow water along slow streams, on margins of ponds, in old ditches and coves. Frequent throughout.

Myriophyllum heterophyllum Michix. Various-leaved water-milfoil. In shallow water of ponds, old ditches, and slow streams. Frequent throughout. 
Proserpinaca palustris L. Mermaid-weed. Very wet places and often in shallow water. Frequent throughout.

Hippuris vulgaris L. Mare's-tail. Ponds, slow shallow streams, and coves. Plentiful throughout.

\section{ARALIACEAE. Ginseng Family}

Aralia racemosa L. Spikenard. In rich woods and thickets, throughout. Frequent.

Aralia hispida Vent. Bristly sarsaparilla. In open dry ground from Bay County to St. Ignace. Plentiful. Abundant on dry burned over ground.

Aralia nudicaulis L. Wild sarsaparilla. In rich shaded ground. Abundant throughout.

Panax quinqucfolium L. Ginseng. Reported throughout but not seen. Collected near Vanderbilt, Otsego County, by Prof. A. E. Bessey, 1912.

Panax trifolium L. Dwarf ginseng. Ground nut. Beech-maple woods. Plentiful throughout.

\section{UMBELLIFERAE. Parsley Family}

Sanicula marilandica I. Sanicle. In rich shaded ground throughout. Plentiful.

Osmorhiza claytoni (Michx.) Clarke. Wooly sweet cicily. In rich open woods throughout. Common.

Osmorhiza longistylis (Torr.) DC. Smoother swcet cicily. Rich open woods from Bay County to St. Ignace, Mackinac County. Frequent.

Osmorhiza divaricata Nutt. Western siveet cicily. Rich shaded ground on Thunder Bay Island, Alpena County. Plentiful. Also on Mackinac Island. F. W. Hunnewell $2 \mathrm{~d}$.

Conium maculatum L. Poison hemiock. About St. Ignace and on Mackinac lsland. Frequent about cities and villages in waste plates.

Cicuta macrilata L. Water hemlock. Marshy open ground from Bay County to Mackinaw City, Cheboygan County. Noticed in particular near Onaway, Presque Isle County.

Cicuta bulbifera I. Bull-bearing water hemlock. In wet open grounel from Bay County to St. Ignace, Mackinac County. Plentiful.

Carum carvi L. Caraway. As a weed throughout in and ahout cities and villages. Often abundant.

Sium ciculuefolium Schrank. Water parsnip. In rery wet open places from Bay County to St. Ignace. Plentiful.

Taenidia integerrima (I.) Drucle. Yellow pimpernell. Dry open shaded ground throughout. Frequent.

Pastinaca sativa L. Parsnip. Along roads and about citics an l ril- 
lages as an escape. Abundant in many places in Cheboygan County, growing in open woods and thickets like a native plant.

Heracleum lanatum Michx. Cow parsnip. Dryish rich open ground from Bay County to St. Ignace, Mackinac County. Plentiful.

Angelica atropurpurea L. Great angelica. Damp, rich open ground in Bay and Arenac counties. Apparently infrequent.

Daucus caroia L. Carrot. Roadsides and old fields near Alpena and Mackinaw City. Apparently becoming a troublesome weed.

\section{CORNACEAE. Dogwood Family}

Cornus canadensis L. Dwarf cornel. In damp or dryish shaded ground throughout. Abundant.

Cornus circinata L'Her. Round-leaved cornel. In dry open or shaded ground throughout, especially near the Lake Huron sandy beaches.

Cornus amomum Mill. Silky cornel. Damp open ground. Apparently infrequent.

Cornus baileyi Coult. \& Evans. Bailey's cornel. Along the sandy shores of Lake Huron from Bay County to Mackinac Island, Mackinac County. Frequent.

Cornus stolonifera Michx. Red-osier dogwood. In wet swampy or (Iry sandy ground from Bay County to Mackinac Island, Mackinac County. Flentiful.

Cornus paniculata L'Her. Panicled cornel. Frequent in damp or dry open ground from Bay County to St. Ignace, Mackinac County. Plentiful.

Cornus alternifolia L.f. Alternate-leaved cornel. Borders of woods and banks of streams. Frequent throughout.

Nyssa sylvatica Marsh. Rich open ground. Noticed near Linwood in Bay County, and near Omer in Arenac County. Apparently infrequent. Not noticed farther north.

\section{ERICACEAE. Heath Family}

Chimaphila umbellata (L.) Nutt. Prince's pine. In dry shaded ground from Bay County to Mackinac Island, Mackinac County. Frequent.

Moneses uniflora (L.) Gray. One-flowered pyrola. Damp rich woods from Bay County to St. Ignace, Mackinac County. Frequent.

Pyrola secunda I. One-sided wintergreen. Rich sharled ground throughout. Frequent.

Pyrola chlorantha Sw. Greenish-flowered wintergreen. In open dryish woods about St. Ignace and Mackinac Island. Plentiful.

Pyrola elliptica Nutt. Shin leaf. In rich shaded ground from Bay County to St. Ignace, Mackinac County. Frequent.

Pyrola asarifolia Michx. Liver-leaf wintergreen. In damp shaded ground from Bay County to St. Ignace, Mackinac County. Plentiful. 
Pyrola asarifolia incarnata (Fisch.) Fernald. Purple-flowered wintergreen. In shaded wet and boggy places from Alpena to St. Ignace and on Mackinac Island. Plentiful.

Monotropa uniflora L. Indian pipe. In rich shaded ground at St. Ignace and on Mackinac Island. Probably frequent throughout, but overlooked.

Ledum groenlandicum Oeder. Labrador tea. In open or sharled boggy ground from Bay County to St. Ignace. Plentiful. One of the dominant bog shrubs of the region.

Kalmia angustifolia L. Sheep laurel. Noticed from Arenac County to Alpena. Very abundant in spots on flat and damp open ground abore $\mathrm{Au}$ Gres and about Oscoda. Said to be a winter food for deer.

Kalmia polifolia Wang. Pale laurel. Open boggy ground from Bay County to St. Ignace, Mackinac County. Plentiful.

Andromeda glaucophylla Link. Bog rosemary. In bogs and very wet places from Bay County to St. Ignace, Mackinac County. Common. One of the dominant bog shrubs of the region.

Chamaedaphne calyculata (L.) Moench. I.eather leaf. In open bogs from Bay County to St. Ignace, Mackinac County. Common and often abundant. One of the dominant bog shrubs of the region.

E'pigaea repens L. Trailing arbutus. Occasional in sandy shaded ground. Often among pines, from Bay County to St. Ignace and on Mackinac Island, Mackinac County. Frequent. Seldom plentiful.

Gaultheria procumbens L. Wintergreen. Dry open or shaded ground, and sometimes in sphagnum swamps from Bay County to Mackinac Island, Mackinac County. Abundant.

Arctostaphylos uva-ursi (L.) Spreng. Bearberry. In open sandyground from Arenac County to St. Ignace, Mackinac County. Plentiful.

Chiogenes hispidula (L.) T. \& G. Creeping snowberry. Wet shaded swampy places and in tamarack swamps. Frequent.

Gaylussacia baccata (Wang.) C. Koch. Black huckleberry. Dry sandy open or shaded ground, sometimes in swamps from Bay County to St. Ignace, Mackinac County. Common. Frequent on jack pine plains. Noticed on sand dunes near Mackinaw City in great abundance loaded with plump juicy fruit, September 23, 1913.

Gaylussacia baccata forma glaucocarpa (Robinson) Mackenzie. Blue huckleberry. Sandy ground and near sandy beaches of Lake Huron from Bay County to Mackinaw City, Cheboygan County. Frequent.

Gaylussacia baccata forma leucocarpa (Porter) Fernald. White huckleberry. Covering sand dunes near Mackinaw City on Septemher 23, 1913. White fruit abundant and juicy. This and the preceding species were growing together.

Vaccinium pennsylranicum Lam. Low sweet blueberry. Common 
from Bay County to St. Ignace. Very abundant in Arenac and Iosco counties on dry open ground and growing with the following variety.

Taccinium pennsyluanicum nigrum Wood. Low black blueberry. Common from Bay County to St. Ignace. Often very abundant and growing with the preceding. These two shrubs produce a great abundance of delicious berries nearly every season, both known in the market as blueberries.

Iaccinium canadiense Kalm. Sour-top. In dry or swampy open ground from Bay County to St. Ignace, Mackinac County. Frequent.

Taccinium corymbosum L. Swamp blueberry. In swampy open or shaded ground from Bay County to St. Ignace, Mackinac County. Frequent.

Vaccinium oxycoccos L. Small cranberry. In sphagnum swamps from Bay County to St. Ignace, Mackinac County. Frequent.

Vaccinium macrocarpon Ait. Large cranberry. American cranberry. Open bogs and swampy places from Bay County to St. Ignace. Frequent.

\section{PRIMULACEAE. Primrose Family}

Primula farinosa L. Bird's eye prinrose. Damp rich shaded ground on Thunder Bay Island in Alpena County. Apparently infrequent.

Primula farinosa americana Farr. Yellow-leaved primrose. In damp sand near Lake Huron shore above Alpena. Apparently infrequent. Perhaps overlooked.

Primula mistassinica Michx. Dwarf Canadian primrose. Damp open ground east side of Mackinac Island. Plentiful. Probably frequent throughout, but overlooked.

Lysimachia terrestris (L.) BSP. Bulb-bearing loosestrife. Low wet ground from Bay County to St. Ignace, Mackinac County. Plentiful.

Lysimachia thyrsiflora L. Tufted loosestrife. In swampy open places throughout. Often in shallow water. Plentiful.

Steironema ciliatum (L.) Raf. Fringed loosestrife. Low usually shaded ground from Bay County to St. Ignace, Mackinac County. Plentiful.

Steironema quadrifiorum (Sims) Hitche. Prairie moneywort. Noticed only in Bay County in marshy or prairie-like ground. Plentiful.

Trientalis americana (Pers.) Pursh. Star flower. In rich shaded ground throughout. Common.

\section{OLEACEAE. Olive Family}

Fraxinus americana L. White ash. In rich damp ground with other trees from Bay County to St. Ignace, Mackinac County. Frequent, but never plentiful.

Fraximus pennsyluanica Marsh. Red ash. Often standing out in the 
open or on borders of woods and on low ground with other trees. Noticed throughout. Frequent.

Fraxinus pensyluanica lancelata (Borkh.) Sarg. Creen ash. Damp) ground with other trees and along streams. Occasional throughout.

Fraximus nigra Marsh. Black ash. In low wet ground from Bay County to St. Ignace, Mackinac County. Before the forest fires it was very abundant in swainps and with other trees in thick woods. Also along low banks of streams.

Syringa vulgaris L. Common lilac. Near Alpena as an escape from cultivation.

GENTIANACEAE. Gentian Family

Gentiana crinita Froel. Fringed gentian. On Mackinac Island as reported by Whitney. Not noticed in 1912.

Gentiana procera Holm. Smaller fringed gentian. Abundant on low damp ground at St. Ignace and on Mackinac Island.

Cientiana linearis latifolia Gray. (G. grayi Kusnezaw) Gray's gentian. Wet marshy open ground near St. Ignace and on Bois Blanc Island, Mackinac County. Plentiful.

Helenia deflexa (Sm.) Griseb. Spurred gentian. Damp shaded ground from Bay County to St. Ignace, Mackinac County. Plentiful.

Menyanthes trifoliata L. Buckbean. In bogs and shallow water from Bay County to St. Ignace, Mackinac County. Frequent.

\section{APOCYNACEAE. Dogbane Family}

Tinca minor 1. Common periwinkle. In and near the cemetery, Mackinac Island. Apparently a permanent escape.

Apocynum androsaemifolium I. Spreading doghane. Dry open ground throughout. Frequent.

A pocynum cannabirum I. Indian henıp. Damp open ground from Bay County to Bois Blane Island, Mackinac County. I'lentiful.

- Apocynum cannabinum hypericifolium (Ait.) Gray. Clasping-leared doghane. Damp open ground in Bay and Arenac Counties. Plentiful.

\section{ASCLEPIADACEAE. Milkweed Family}

Asclepias incarnata. L. Swamp milkweed. Damp open ground from Bay County to St. Ignace, Mackinac County. Infrequent.

Asclepias syriaca L. Common milkweed. In sandy open ground throughout but seldom abundant. Apparently infrequent northward.

Asclepias phytolaccoides Pursh. Poke milkweed. In moist shaded or open ground near Rogers in Presque Isle County. Apparently infiequent. 


\section{CONVOlvUlaCEAE. Convolvulus Family}

Convolvulus spithamaeus L. Upright bindweed. From Bay County to St. Ignace, Mackinac County. Frequent. Very abundant on rocky open or shaded ground in Presque Isle and Cheboygan counties. Noticed as an abundant and troublesome weed on the farm of Albert Robinson near Onaway in Presque Isle County.

Convolvulus sepium L. Hedge bindweed. From Bay County to St. Ignace, Mackinac County. Cslially in damp open ground. Apparently infrequient.

\section{BORAGINACEAE. Borage Family}

Cynoglossum officinale I. Common hound's tongue. In dry open ground throughout. Frequent.

Cynoglossum boreale Fernald. Northern wild comfrey. In open dryish woods from Bay County to Mackinac Islitnd, Mackinac County. Frequent.

Lappula virginiana (L.) Greene. Begger's lice. Rich shaded ground from Bay County to St. Ignace, Mackinac County. Frequent. Abundant in hardwoods east of Onaway, Presque Isle County.

Lappula echinata Gilibert. European stickseed. Noticed throughout on rcadsides and in cities and villages. A harmless weed except that the burs get into wool.

Lappula redowskii occidentalis (Wats.) Rydb. Western hairy stickseed. Noticed in open ground not far from Lake Huron shore above Alpena. Apparently infrequent.

Symphytum officinale L. Common comfrey. Noticed in open ground near Harrisville and Alpena. Apparently infrequent.

Myosotis virginica macrosperma (Engelm.) Fernald. Larger spring scorpion-grass. In dryish slightly shaded ground on Mackinac Island. F. W. Hunnewell 2nd. Apparently infrequent.

Lithospermum officinale L. Common gromwell. Dry open or shaded ground at St. Ignace and on Mackinac Island. Plentiful. Not noticed elsewhere.

Lithospermum gmclini (Michx.) Hitchc. Hairy puccoon. Sandy open ground near Lake Huron shore from Bay County to St. Ignace, Mackinac County. Frequent.

Lithospermum angustifolium Michx. Narrow-leaved puccoon. Noticed in dry open ground only at St. Ignace, Mackinac County. Probably to be found throughout but overlooked.

Échium vulgare L. Blue-weel. Noticed only in open ground on Mackinac Island. As a weed it is extending northward.

VERBENACEAE. Vervain Family

Terbena hastata L. Blue vervain. From Bay County to St. Ignace, Mackinac County. Apparently infrequent. 
LABIATAE. Mint Family

Scutellaria laterifolia L. Mad-dog skullcap. Damp shaded ground from Bay County to St. Ignace, Mackinac County. Frequent.

Scutellaria galericulata L. Marsh skulleap. Wet open ground throughout. Frequent.

Marrubium vulgare L. Common horehound. Occasional as an escape about cities and villages.

Nepeta cataria L. Catnip. In cities and villages throughout. Apparently searce.

Nepeta hederacea (L.) Trevisan. Ground ivy. Open dryish or damp shaded ground. Frequent and appearing like a native plant.

Prunella vulgaris L. Heal-all. Open or shaded ground. Frequent throughout.

Galeopsis tetrahit L. Common hemp nettle. "Abundant on Mackinac Island." Winchell's Cat. Noticed as abundant on the bluff near the park, Mackinac Island, in 1913.

Leonurus cardiaca L. Common motherwort. About cities and villages and in cultivated grounds. Frequent throughout.

Monarda mollis L. Pale wild bergamot. Dry open ground throughout. Frequent.

Blephitia hirsuta (Pursh.) Benth. Moist shaded ground on Bois Blane Island, Mackinac County. A pparently infrequent.

Satureja glabra (Nutt.) Fernald. Low calamint. In damp open ground near Lake Huron shore from Alpena to Mackinac Island, Mackinac Cointy. Frequent.

Sature, valgaris (L.) Fritsch. Basil. Dry open ground from Bay County to St. Ignace, Mackiruac County. Frequent.

Lycopus uniflorus Michx. Bugle-weed. Low open or shaded ground. Plentiful throughout.

Lycopus americanus Muhl. Cut-leaved water horehound. In damp open or shaded ground from Bay County to St. Ignace, Mackinac County. Frequent.

Mentha spicata L. Spearmint. About cities and villages and along roarls. Infrequent.

Mentha piperita L. Peppermint. In damp open ground from Bay County to St. Ignace, Mackinac County. Occasional throughout.

Mentha citrata Ehrh. Bergemot mint. Well established and plentiful in an old field near Misery Bay northeast of Alpena, Alpena County.

Mentha arvensis canadensis (L.) Briquet. American wild mint. Damp open or shaded ground from Bay County to St. Ignace, Mackinac County. Frequent. 
shaded ground throughout. Growing like a native plant even in woods and swamps.

Solanum nigrum L. Black nightshade. Shaded or rich open ground, usually as a weed in cities and villages. Infrequent.

Physalis grandiflora Hook. Large white-flowered ground cherry. In sandy open ground near Alpena. Apparently infrequent.

* Physalis heterophylla Nees. Clamy ground cherry. In dry and sandy open ground from Bay County to St. Ignace. Frequent.

Lycium halimifolium Mill. Common matrimony vine. Occasional as an escape about cities and villages.

Hyoscyamus niger L. Black henbane. Noticed at St. Ignace and on Mackinac Island, as a sort of weed in waste places.

\section{SCROPHULARIACEAE. Figwort Family}

Verbascum thapsus L. Common mullein. As a weed along roads, in pastures, old fields and open woods. Frequent throughout.

Linaria vulgaris Hill. Butter and eggs. Throughout as a weed in and near cities and villages. Often plentiful.

Linaria canadensis (L.) Dumont. Blue toad-flax. In dry sandy open or slightly shaded ground from Bay County to Alpena. Not noticed farther north.

Scrophularia leporclla Bicknell. Hare figwort. In dryish open ground from Bay County to St. Ignace, Mackinac County. Frequent.

Pentstemon hirsutus (I.) Willd. Hairy beard-tongue. Dry open or nartially shaded ground from Bay County to Mackinac Island, Mackinac County. Frequent.

Chelone glabra L. Turtlehead. Wet open places from Bay County to St. Ignace, Mackinac County. Frequent.

Mimulus ringens L. Square-stemed monkey-flower. Wet open ground from Bay County to St. Ignace, Mackinac County. Frequent.

Mimulus glabratus jamesii (T. \& G.) Gray. James' mimulus. In very wet springy places on Mackinac Island, Mackinac County, and near Presque Isle Bay, Presque Isle County. Plentiful.

I'eronica americana Schwein. American brooklime. In and near brocks, ditches and very wet places from Bay County to St. Ignace and on Mackinac Island. Plentiful and often abundant.

Teronica scutellata L. Marsh speedwell. In damp open ground from Bay County to St. Ignace, Mackinac County. Frequent.

Veronica officinalis L. Common speedwell. Dryish open or shaded ground from Bay C'ounty to Mackinac Island, Mackinac County. Frequent throughout.

I'eronica serpyllifolia L. Thyme-leaved speedwell. In open or shaded grassy ground throughout. Plentiful. 
Veronica peregrina L. Purslane speedwell. Gardens and waste grounds about cities and villages. Frequent.

Gerardia paupercula (Gray) Britton. Small-flowered gerardia. In sterile or wet boggy ground from Bay County to St. Ignace. Frequent.

Castilleja coccinea (L.) Spreng. Scarlet painted cup. Damp open ground from Bay County to Mackinac Island, Mackinac County. Plentiful. Often abundant.

Melampyrum lineare Lam. Cow wheat. Dryish open woods from Bay County to St. Ignace, Mackinac County. Frequent. Often plentiful.

Pedicularis canadensis L. Common lousewort. Dryish shaded ground from Bay County to St. Ignace, Mackinac County. Frequent.

Pedicularis lanceolata Michx. Swamp lousewort. Wet swampy places. Frequent throughout.

LENTIBULARIACEAE. Bladderwort Family

Utricularia vulgaris americana Gray. Greater bladderwort. Ponds, small lakes, coves and ditches from Bay County to St. Ignace, Mackinac County. Frequent.

Utricularia intermedia Hayne. Flat-leaved bladderwort. In wet mossy open places from Bay County to Mackinac Island, Mackinac County. Frequent. Often abundant.

Utricularia cornuta Michx. Horned bladderwort. In damp sand near Iake Huron shore from Bay County to St. Ignace, Mackinac County. Frequent. Often abundant.

Pinguicula vulgaris L. Butterwort. On wet rocky beach of Thuncler Bay Island in Alpena County. Plentiful. Perhaps more frequent but overlooked.

\section{OROBANCHACEAE. Broom-rape Family}

Epifagus virginiana (L.) Bart. Beech diops. Under beeches from Bay County to Mackinac Island, Mackinac County. Frequent, often plentiful.

Conopholis americana (L. f.) Wallr. Squaw-root. In oak-maple woods on Mackinac Island. Apparently rars. Probably overlooked.

Orobanche uniflora L. One-flowered cancer-root. Abundant in spots on Mackinac Island. Probably frequent throughout but overlooked.

\section{PLANTAGINACEAE. Plantain Family}

Plantago major L. Common plantain. Occasional throughout, especially near cities and villages.

Plantago rugelii Done. Rugel's plantain. Noticed as occasional in cultivated grounds near cities and villages.

Plantago lanceolata L. English plantain. Becoming common as a 
weed throughout along roads, in pastures, cultivated fields and waste places.

\section{RUBIACEAE. Madder Family}

Galium aparine L. Cleavers. Noticed in Cheboygan County and on Mackinac Island, usually in rich shaded ground. Plentiful.

Galium circaezans Michx. Wild liquorice. Rich woods from Bay County to St. Ignace, Mackinac County. Frequent.

Galium lanceolaturi Torr. Torry's wild liquorice. Dryish open woods from Bay County to Mackinac Island, Mackinac County. Frequent.

Galium boreale L. Northern bedstraw. Dryish open ground from Bay County to St. Ignace, Mackinac County. Frequent.

Galium trifidum L. Small bedstraw. In damp open ground from Bay County to Mackinac Island, Mackinac County. Plentiful.

Galium tinctorium L. Stiff marsh bedstraw. Damp open or partially shaded ground from Bay County to St. Ignace. Plentiful.

Galium asprellum Michx. Rough bedstraw. In damp shaded ground from Bay County to Mackinac Island, Mackinac County. Plentiful.

Galium triflorum Michx. Sweet-scented bedstraw. In open rich woods and thickets throughout. Common.

Mitchella repens L. Partridge berry. In dryish open woods from Bay County to St. Ignace and on Mackinac Island, Mackinac County. Plentiful.

Cephalanthus occidentalis I. Button-bush. Near Linwood in Bay County. Not noticed farther north.

Houstonia ciliolata Torr. Fringed houstonia. Abundant in spots often covering the ground on Thunder Bay Island in Alpena County. Apparently infrequent.

\section{CAPRIFOLIACEAE. Honeysuckle Family}

Diervilla lonicera Mill. Bush honeysuckle. Common and often abundant throughout in dry sandy open or slightly shaded ground.

Lonicera tatarica I. Tartarian honeysuckle. An occasional escape about cities and villages.

Lonicera canadensis Marsh. American fly honeysuckle. In open woods from Bay County to St. Ignace and Bois Blanc Island, Mackinac County. Plentiful.

Lonicera oblongifolia (Golclie) Hook. Swamp fly honeysuckle. In swampy places from Bay County to St. Ignace, Mackinac County. Frequent.

Lonicera hirsuta Eat. Hairy honeysuckle. In rich open or partially shaded ground from Alpena County to St. Ignace and on Mackinac Island, Mackinac County. Frequent. 
Lonicera glaucescens Rydb. Douglas' honeysuckle. In dryish open or partially shaded ground from Bay County to St. Ignace, Mackinac County. Frequent.

Lonicera dioica L. Glaucous honeysuckle. Dryish open or partially shaded ground from Bay County to St. Ignace, Mackinac County. Plentiful.

Symphoricarpos occidentalis Hook. Wolfberry. Dry open ground about Mio, Oscoda County. Abundant.

Symphoricarpos racemosus Michx. Snowberry. In dry open or partially shaded ground from Pay County to St. Ignace and on Mackinac Island, Mackinac County. Frequent. Also plentiful about Mio, Oscorla County.

Linnaca borealis americana (Forbes) Rehder. Moist, usually shaded ground from Bay County to Mackinac Island, Nackinac County, where it is very alsundant.

Viburnum opulus americanum (Mill) Ait. Cranberry-tree. Rich open woods and along streams from Bay County to Bois Blanc Island, Mackinac County. Plentiful.

Viburnum acerifolium L. Arrow-wood. In open woods from Bay County to Mackinaw City, Cheboygan County. Plentiful.

Tiburnum pubescens (Ait.) Pursh. Downy arrow-wood. Dryish open woods in Alpena and Cheboygan counties. Plentiful. Noticed in particular as abundant at Misery Bay near Alpena.

Tiburnum cassinoides L. Withe-rod. In wet open ground from Pay County to St. Ignace. Common.

Viturnum lentago L. Nannyberry. In damp open woods and thickets from Bay County to St. Ignace and on Mackinac Island, Mackinac Connty. Plentiful.

Sambucus canadensis L. Common elder. In damp open ground from Bay County to St. Ignace, Mackinac County. Frequent.

Sambucus racemosa L. Red-berried elder. Damip open or shaded ground throughout. Common.

\section{VALERIANACEAE. Valerian Family}

Valeriana officinalis I. Garden heliotrope. Appears to be permanently established as an escape in open dry ground in Presque Isle and Cheboygan counties. Plentiful.

\section{CUCURBITACEAE. Gourd Family}

Echinocystis lobata (Michx.) T. \& G. Wild balsam apple. Apparently an escape from Bay County to St. Ignace, Mackinac County. Frequent.

CAMPANULACEAE. Bluebell Family

Campanula rapunculoides L. Creeping bellflower. As an escape from Bay County to Mackinac Island, Mackinac County. Frequent. 
Campanula rotundifolia L. Harebell. On dry and sandy open ground, especially near the Lake Huron shore. Common throughout.

Campanula aparinoides Pursh. Marsh bellflower. Wet grassy ground from Bay County to St. Ignace, Mackinac County. Frequent.

LOBELIACEAE. Lobelia Family

Lobelia kalmii L. Kalm's lobelia. In wet open ground from Bay County to Mackinac Island, Mackinac County. Plentiful.

\section{COMPOSITAE. Composite Family}

Eupatorium purpureum I. Joe-pye weed. Low open ground or often in damp open woods from Bay County to St. Ignace, Mackinac County. Frequent.

Eupatorium purpureum maculatum (L.) Darl. Spotted joe-pye weed. In marshy open places. Frequent throughout.

Eupatorium perfoliatum I. Boneset. Wet marshy open ground. Common throughout.

Liatris cylindracea Michx. Cylindric blazing star. Dry open ground. Plentiful on jack pine plains of Presque Isle, Montmorency, Oscoda and Ogemaw counties.

Liatris scariosa Willd. Jarge button snakeroot. Dry open ground from Bay County to Mackinaw City, Cheboygan County. Plentiful especially on jack pine plains.

Grindelia squarrosa (Pursh.) Dunal. Broad-leaved gum-plant. In dry open ground from Bay County to Mackinaw City. Frequent in fields and about cities and villages.

Solidajo latifolia L. Broad-leaved goldenrod. Common in rich shaded ground from Bay County to Mackinac Island, Mackinac County. Plentiful.

Solidago hispida Muhl. Hairy goldenrod. In dry open or partially shaded ground from Bay County to Mackinac Island, Markinac County. Plentiful.

Solidago randii (Porter.) Britton. Rand's goldenrod. Dry sandy ground, usually on or near the sandy beaches of Lake Huron from Alpena to St. Ignace, Mackinac County. Frequent.

Solidago racemosa gillmani (Gray) Fernald. Gillman's goldenrod. Sandy shore near Mackinaw City, Cheboygan County. Apparently infrequent. Perhaps overlooked.

Solidago uliginosa Nutt. Bog goldenrod. Bogs and wet marshy places from Bay County to St. Ignace, Mackinac County. Frequent. Often plentiful.

Solidago speciosa angustata T. \& G. Slender goldenrod. In dry open ground from Bay County to Mackinaw City, Cheboygan County. Frequent. 
Solidago juncea Ait. Early goldenrod. Dry open ground from Pay County to St. Ignace, Mackinac County. Frequent. Often plentiful. Solidago rugosa Mill. Wrinkle-leaved goldenrod. Open dry ground from Bay County to St. Ignace, Mackinar County. Plentiful.

Solidago nemoralis Ait. Gray goldenrod. Dry open ground throughout. Plentiful.

Solidago canadensis L. Canada goldenror. Rich open or partially shaded ground from Bay County to St. Ignace, Mackinac County. Plentiful and often aburidant.

Solidago altissima L. Tall goldenrod. Rich open ground from Bay County to St. Ignace, Mackinac County. Frequent. Often abundant.

Solidago serotina Ait. Late Goldenrod. Rich open or partially shaded ground from Bay County to St. Ignace, Mackinac County. Plentiful.

Solidago ohiocnsia Riddell. Ohio goldenrod. Swamps and wet prairielike ground from Bay County to St. Ignace, Mackinac County. Frequent. Often abundant.

Solidago houghtonii T. \& G. Houghton's goldenrod. Dry sandy ground usually on or near sandy beach of Lake Huron. Noticed in particular near St. Ignace and on Bois Blanc Island, Mackinac County.

Solidago graminifolia (L.) Salisb. Bushy goldenrod. Moist onen ground or in damp sand on or near sandy beaches of Lake Huron from Bay County to St. Ignace, Mackinac County. Plentiful.

Aster macrophyllus I. I arge-leaved aster. Rich shaded ground. Abundant throughout.

Aster novae-angliae L. New England aster. In moist mostly open ground from Bay County to St. Ignace, Mackinac County. Apparently infrequent.

Aster sagittifolius Wedemeyer. Arrow-leaved aster. Dry open or partially shaded ground from Bay County to Mackinac Island, Mackinac County. Plentiful. Often abundant.

Aster lindleyanus T. \& G. Lindley's aster. Common in open or slightly shaded ground from Presque Isle County to Mackinac Island, Mackinac County. Plentiful. Also near Alpena.

Aster laevis L. Smooth aster. Dry open or partially shaded ground from Bay County to St. Ignace, Mackinac County. Plentiful.

Aster polyphyllus Willd. (Aster faxoni Porter). Faxon's aster. Gravelly open ground usually near beach on Bois Blanc Island. Frequent.

Aster lateriflorus (L.) Britton. Calico aster. Damp or dryish open or partially shaded ground. Frequent. Often plentiful throughout.

Aster tradescanti L. Tradescant's aster. In damp open or shaded ground from Bay County to Mackinac Island, Mackinac County. Plentiful. Often abundant. 
Aster paniculatus Lam. Panicled aster. In damp or dryish open or partially shaded ground throughout. Frequent.

Aster salicifolius Ait. Willow aster. L.ow open ground near Mackinaw City, Cheboygan County. Apparently infrequent.

Aster junceus Ait. Rush aster. In marshy open ground from Bay County to St. Ignace, Mackinac County. Plentiful.

Aster longifolius Lam. Long-leaved aster. Low damp ground on Bois Blane Island. Plentiful.

Aster puniceus L. Rerl-stalk aster. Wet open or partially shaded ground from Bay County to St. Ignace, Mackinac County. Frequent.

Aster umbellatus Mill. Tall flat-top white aster. Moist partially shaded ground from Bay County to St. Ignace, Mackinae County. Frequent. Often plentiful.

Aster ptarmicoides T. \& G. Tpland white aster. Dry level ground on jack pine plains north of Rose City, Ogemaw County. Plentiful.

Erigeron mulchellus Michx. Robin's plantain. Mostly open dryish ground, Bay County. Frequent.

Erigeron philadelphicus L. Philadelphia fleabane. Field daisy. Damp open ground. Frequent throughout.

Erigeron annuus (I.) Pers. Sweet scabious. Esually in rich open or partially shaded ground. Plentiful throughout. Often a weed in pastures and hay fields.

Erigeron ramosus (Walt.) BSP. Daisy fleabane. Dry open ground along roads, in fields and pastures. Frequent throughout.

Erigeron canadensis L. Horse-rreed. About cities and villages, in pastures, and on open burned over ground. Frequent throughout. Appearing as if introduced.

Antennaria canadensis Greene. Canadian cat's-foot. In dry open or partially sharled ground. Frequent throughout.

Antennaria fallax Greene. Tall cat's-foot. Rich open or shaded ground from Bay County to Mackinac Island, Mackinac County. Plentiful.

Antennaria ncodioica Greene. Smaller cat's-foot. Damp open or partially shaded ground from Bay County to Mackinac Island, Mackinac County. Frequent.

Antennaria neglecta Greene. Field cat's-foot. In open or shaded ground from Bay County to Mackinac Island. Plentiful. Often abundant.

Antennaria petaloidea Fernald. Common cat's-foot. In dry open or partially shaded ground from Bay County to St. Ignace, Mackinac County. Plentiful. Often abundant.

Anaphalis margaritacea (L.) B. \& H. Pearly everlasting. Dry open or partially shaded ground from Bay County to Mackinac Island, Mackinac County. Frequent. Often abundant. 
Gnaphalium polycephalum Michx. Common everlasting. From Bay County to St. Ignace in fields and open ground. Apparently infrequent. Gnaphatium decurrens Ives. Clammy everlasting. Dry open ground from Bay County to St. Ignace, Mackinac County. Apparently infrequent.

Gnaphatium uliginosum I. Low cudweed. Damp or dry open ground throughout. Frequent.

Inula helenium L. Elecampane. Noticed along roads near Pinconning in Bay County. Plentiful. Not noticed farther north.

Iva xanthifolia Nutt. Burweed marsh elder. In waste places of cities and villages. Infrequent. Noticed in particular at Alpena and Mackinaw City.

Ambrosia trifida L. Great ragweed. Waste places of cities and rillages and about dwellings. Occasional throughout.

Ambrosia artemisiifolia L. Common ragweed. Occasional throughout as a weed, especially in cities and villages.

Ambrosia psilostachya DC. Western ragweed. Becoming frequent throughout as a weed in cities and villages and about dwellings.

Xanthium canadense Mill. American cocklebur. Occasional in waste places of cities. Noticed in particular at Alpena and Cheboygan.

Rudbeckia hirta L. Yellow daisy. Black-eyed-susan. In dry open ground throughout, but apparently infrequent.

Helianthus occidentalis Riddell. Few-leaved sunflower. Jack pine plains south of Mio, Oscoda County. Plentiful in one locality.

Helianthus divaricatus L. Woodland sunflower. Jack pine plains near Mio, Oscoda County, and Rose City, Ogemaw County.

Helianthus tuberosus I. Jerusalem artichoke. Well established in old field at Misery Bay near Alpena.

Coreopsis lanceolata L. Lance-leaved tickseed. First noticed in sandy open ground near Lake Huron shore at Alpena. Common from there to St. Ignace and on Mackinac Island. Flowers yellow, beautiful.

Bidens frondosa L. Begger-ticks. Damp open ground from Bay County to St. Ignace. Seldom plentiful.

Bidens comosa (Gray) Wiegand. Leafy-bracted ticksecl. Rich ground and damp sandy shores from Bay County to St. Ignace, Mackinac County. Plentiful.

Bidens connata Muhl. Swamp beggar-ticks. Wet open places from Bay County to St. Ignace. Frequent.

Bidens cernua L. Stick-tight. Wet open places throughout. Frequent.

Achillea millefolium L. Common yarrow. A weed alsout cities and villages throughout. Apparently infrequent.

Anthemis cotula L. May-weed. Only as a weed alout cities and rillages. Not plentiful. 
Chrysanthemum leucanthemum pinnatifidum.Lecoq \& Lamotte. Oxeye-daisy. From Bay County to St. Ignace, Mackinac County. A pernicious weed in Cheboygan County.

Chrysanthemum parthenium (L.) Bernh. Common feverfew. Waste places of cities and villages. Apparently not a permanent escape.

Chrysanthemum balsamita tanacetoides Boiss. Costmary. Well established throughout as an escape, usually in dry open ground, along roads and in old fields. Frequent.

Tanacetum vulgare L. Common tansy. Roadsides and about cities and villages as an escape throughout. Frequent.

Tanacetum huronense Nutt. Lake Huron tansy. On and near sandy beach of Lake Huron from Alpena to St. Ignace. Plentiful. Often abundant.

Artemisia caudata Michx. Tall wormwood. Sandy beaches of Lake Huron throughout, and often in open sandy ground and on sandy ridges in the interior. Plentiful.

Artemisia abrotanum L. Southernwood. Persisting near Alpena in dry open ground. Apparently infrequent.

Artemisia pontica L. Roman wormwood. Along roads near Mio, Oscoda County. Apparently infrequent.

Artemisia stelleriana Bess. Beach wormwood. Sandy open ground as a permanent escape from Bay County to St. Ignace. Often on sand dunes.

Artemisia biennis Willd. Biennial wormwood. Dry or damp open ground in and about cities and villages. Frequent.

Artemisia absinthium L. Wormwood. Dry open ground about cities and villages. Frequent.

Petasites palmatus (Ait.) Gray. Palmate-leaf sweet coltsfoot. In rich open or shaded ground from Bay County to St. Ignace and on Mackinac Island, Mackinac County. Frequent and often plentiful.

Erechtites hieracifolia (I.) Raf. Fireweed. Usually in rich open or shaded ground and noticed from Bay County to St. Ignace, Mackinac County. Frequent. Abundant on burnt over ground.

Senecio vulgaris I. Common groundsel. Noticed as abundant about the village of Mackinac Island, Mackinac County.

Senecio aureus L. Golden ragwort. In wet and marshy open or shaded ground throughout. Frequent. Often plentiful.

Senecio balsamitae Muhl. Balsam groundsel. In dry open or shaded ground, mostly on or near sandy beach of Lake Huron. Frequent throughout.

Arctium minus Bernh. Common burdock. Cities, villages and generally in cultivated grounds. Often in open woods, like a native plant. Plentiful. 
Cirsium lanceolatum (L.) Hill. Common thistle. Roadsides and in cultivated grounds. Not abundant or prominent anywhere.

Cirsium pitcheri (Torr.) T. \& C. Pitcher's thistle. On sandy beach of Lake Huron from Arenac County to St. Ignace and on Mackinac Island. Plentiful.

Cirsium discolor (Muhl.) Spreng. Field thistle. In dryish open or shaded ground. Occasional throughout.

Cirsium muticum Michx. Swamp thistle. In swampy open or slightly shaded ground throughout. Frequent.

Cirsium arvense (L.) Scop. Canada thistle. Common in Bay County. Occasional from Arenac County to Alcona County. Abundant from Alpena to Mackinaw City and on Mackinac Island.

Lapsana communis L. Nipple-wort. Mostly in shaded ground on Mackinac Island. Abundant in spots. Not noticed elsewhere.

Cichorium intybus L. Common chickory. Along roadsides and in cultivated grounds, but seldom plentiful. Noticed throughout.

Krigia virginica ( $\mathrm{I}_{\text {.. }}$ ) Willd. Carolina dwarf dandelion. In sandy open or slightly shaded ground in Arenac and Iosco counties, and noticed as far as Alpena. Often abundant.

Tragopogon porrifolius L. Salsify. In cities and villages and along railroarls throughout. Frequent.

Tragopogon pratensis L. Goat's beard. In cities and villages and along railroads. Seldom plentiful.

Taraxacum officinale Weber. Common dandelion. Abundant in Bay County. Infrequent in Arenac and Iosco comties. Nore abundant from Alcona County to St. Ignace and on Mackinae Island.

Sonchus arvensis L. Field sow thistle. In cities and villages especially depot grounds. Frequent. Occasional in cultivated fields.

Sonchus oleraceus L. Common sow thistle. Gardens and in waste places of cities and villages throughout. Seldom plentiful.

Sonchus asper (L.) Hill. Spiny-leaved sow thistle. About cities and villages. Not noticed in uncultivated grounds.

Lactuca scariola integrata Gren. \& Codr. Prickly lettue'e. Throughout but apparently searce.

Lactuca canadensis L. Wild lettuce. In open or partially shaded ground. Frequent throughout.

Lactuca spicata (Lam.) Hitche. Tall blue lettuce. In rich open or partially shaded ground. Frequent throughout.

Prenanthes racemosa Michx. Glaucous white lettuce. Damp open prairie-like ground near Cheboygan and St. Ignace. Apparently infrequent.

Prenanthes alba L. White lettuce. Noticed in rich open or shaded ground from Bay County to St. Ignace and Mackinac Island, Mackinac County. Frequent throughout. 
Hieracium auriantiacum L. Orange hawkweed. First noticed about two miles north of Alpena. Very abundant and a pernicious weed from there to and in Presque Isle and Cheboygan counties. Reported as appearing there about ten years ago.

Hieracium venosum L. Rattlesnake-weed. Frequent in dry open or slightly shaded ground from Bay County to St. Ignace, Mackinac County.

Hieracium scabrum Michx. Rough hawkweed. Dry open ground from Bay County to St. Ignace, Mackinac County. Frequent throughout.

Hieracium canaiense Michx. Canada hawkweed. Noticed in dry open ground from Bay County to St. Ignace, Mackinac County. Frequent throughout.

Hiercicium umbellatum L. Narrow-leaved hawkweed. Dry open of partially shaded ground from Alpena to Mackinac Island, Mackinac County. Frequent. 
OBSERVATIONS ON THE FLOWERING PLANTS, FERNS AND FERN ALLIES GROWING WLLD IN SCHOOLCRAFT COUNTY AND VICINITY IN THE UPPER PENINSULA OF MICHIGAN IN 1915

During the season of 1915 a camp for general biological work was established on the bank of Manistique River, perhaps 22 or more miles northeast of the city of Manistique, at a place known as Floodwood, a very wild and uninhabited locality. It having been decided to examine also the wild plants of the region, the writer undertook the work. As the wild vegetation of Mackinac and Chippewa Counties had previously received some attention, it was thought best as far as time would permit, to connect the present with former work.

\section{SCHOOLCRAFT COUNTY}

This county is bounded on the south by Lake Michigan, east by Mackinac and Luce counties, north by Alger County, west by Alger County in part and by Delta County. It is from 36 to 40 miles north and south and from 30 to 36 miles east and west. Its Lake Michigan shore line is about 40 miles and its northern boundary is from less than 6 to 12 miles from the south shore of Lake Superior. Manistique, the county seat on Iake Michigan, is about 300 miles and the south shore of Lake Superior about 350 miles from the south state line. From the city of Detroit it is about 165 west and 200 miles north. The city of Manistique has a population of about 5,000, all other places being rer'y small, and the county in general being sparsely settled. So far as the writer has been able to learn there is no available literature on the wild plants of this region.

\section{General Surface Conditions}

The surface of the county is very irregular and much broken iip into tamarack-black spruce swamps, cranberry marshes, large olven wet and undirained areas, jack pine plains, sand ridges, and sand durcs, small spots and larger tracts of hardwoods. Comparatively speaking it is not a rocky country as is so generally supposed by those who have not visited the county. No rock outcropping in the county was noticed except limestone exposures along or near the Lake Michigan shore. White and Norway pines were formerly quite abundant in many places, but such tracts were mostly long ago lumbered, shrubs and small trees only now remaining. Very small areas of original pine are occasionally 
seen. After the removal of the timber, the hardwood lands are being used successfully for farming purposes. There are large tracts of burned over ground which now are covered mostly with the wild red cherry, not generally with poplars and white birch as is so often the case in the Lower Peninsula. At present it generally appears throughout that if the country were left to itself, it would ultimately return to its former forest covering.

\section{Streams and Syall Lakes}

The Manistique River with its branches is the only stream of any importance, its source being Manistique Lake, lying between Luce County and the northwestern part of Mackinac County. It is a very winding and swift-running stream, evidently having changed its bed many times. Three interior lakes not far from the Lake Michigan shore, Indian Lake, McDonald Lake, and Gulliver Lake, are worthy of mention. Many smaller lakes and permanent ponds were noticed throughout the county.

\section{Shores and Beaches of the Two Great Lakes}

The shores of these lakes are from 40 to nearly 50 miles apart, on a straight north and south line. In many ways they are much alike, especially the sandy beaches, and have many like characteristic plants. Among those common on both shores may be mentioned: Equisetum variegatum, Juniperus communis depressa, Juniperus horizontalis, Calamovilfa longifolia, Ammophila arenaria, Agropyron dasystachyrum, Elymus canadcnsis, Scirpus occidentalis, Scirpus americanus, Smilacina stellata, Salix glaucophylla, Sirlix syrticola, Cakile edentula, Potentilla anserina, Lathyrus maritimus, II udsonia tomentosa (or the variety), Solidago randii, Tanacetum huronense, Artemisin caudata, Cirsium pitcheri.

\section{Plants Worthy of Special Mention}

Becch, yellow birch, and sugar maple are the dominant trees of the hardwoods, mingled in various proportions. Scattered among these are large American elms, striped maple, white birch, mountain maple, ironwood, hemlock, balsam, red maple, and mountain ash. Tamarack, abundant throughout in tamarack-black spruce swamps, is being attacked and killed by the saw-fly, an insect pest from Europe. The black spruce of these swamps is usually small. White spruce is scattering and often being attacked by the dwarf mistletoc. White cedar is apparently scarce at the present time. Two species of oak, bur oak and swamp white oak, the latter often called locally "blue oak," were noticed as occasional along streams, and red oak, usually quite small, on open sandy ground and on sand dunes. Specimens of oak from Grand Island were sent to Prof. C. S. Sargent and he pronounced them to be Quercus 
borealis Michx.f., northern red oak. Black ash is common along streams and in swampy places. Many small trees of green ash were noticed on borders of hardwoods; and red ash occurred a!ong streams, being very abundant on the low banks of the Tahquamenon River in Luce County. The red maple is frequent in damp rich ground with other trees, where it is of fair size, but it is also as a shrub or small scraggy tree common on dry sandy ground and on sand dunes. The wild black cherry was observed throughout, but it is not plentiful. Various species of willows are abundant, but poplars are seldom plentiful. Salix pellitu along the low banks of the Tahquamenon River in Luce County was of special interest. The balsam poplar is often large but seldom abundant. Very large juneberries were found in rich ground with other trees not far from the Lake Michigan shore in the western part of Nackinac County.

\section{Ground Traversed}

About 35 days were spent in the field, from June 24 to July 9 and from September 4 to 25, 1915. From St. Ignace in Mackinac County, the shore of Lake Michigan was followed wcsterly as near as was possible with horse and rig to Naubinway within about 20 miles of the western line of Schoolcraft County, the rest of the way by rail to the city of Manistique. Most of the time of the June trip was spent in the vicinity of the city of Manistique and at the camp near Floodwood. The vicinity of Floodwood was very wild and there was little to indirate near or even remote civilization except forest devastation. A large black hear was killed by Joseph Richey not far from the camp; porcupines appeared to be plentiful and deer abundant. In September a trip was made with a livery rig from Newberry in Luce County to Deer Park on the south shore of Lake Superior, dorn the Tahquamenon River by launch to the upper falls, from Seney in Schoolcraft County north to Grand Marais on the south shore of Lake Superior in Alger County and then to Munising and Grand Island in the same county where some investigation was also made. By far the most beautiful place the writer has yet seen on the Great Lakes is Grand Island and ricinity.

\section{Wide Range of Some of the Shrubs and Trees}

The following appear to be common, or at least occasional, from the south line of the State to the south shore of Lake Superior: Larix laricina, Salix lucida, Salix longifolia, Salix pedicellaris, Salix petiolaris, Salix humilis, Salix candida, Populus tremuloides, Populus grandidentata, Populus balsamifera, Ostrya virginiana, Betula lutea, Alnus incana, Fagus grandifolia, Quercus macrocarpa, Quercus rubra, LTmus americana, Amelanchier laevis Wiegand, Crataegus punctata, Prunus serotina, Prunus pennsylvanica, Prunus virginiana, Rubus idacus aculeatissimus, Pyrus 
arbutifoliu atropurpurea, Rhus glabra, Rhus toxicodendron, Ilex verticillata, Acer spicatum, Acer saccharun, Acer rubrum, Rhamnus alnifolia, Tilia americana, Cornus circinata, Cornus stolonifera, Cornus alternifolia, Fraxinus nigra, Fraxinus pennsylianica, Fraxinus pennsylvanica lanceolata, Viturnum opulus americanum, Viburnum cassincides, Viburnum lentago, Sambucus cunadensis, and Sambucus racemosa. Very many species of herbaceous plants extend over the same range.

The natural order and nomenclature, as given in Gray's New Manual of Botany, Illustrated, have generaliy' been followed unless otherwise stated.

The writer is much indebted to Prof. A. S. Hitcheock and Agnes Chase of the United States Derartment of Agriculture for an examination and determination of the grasses, and to K. K. Mackenzie of New York City for an examination of all species of Cyperaceae and many other plants. In the genus Care:: Mr. Mackenzie's determinations and names have been strictly followed.

If any of these names at present are not found in the two manuals now commenly used, they will soon appear in the forthcoming North American Flora. When the scientific names of Gray's "New Manual of Botany" differ from those in Britton and Brown's "Illustrated Flora," Second Fdition, the latter are given in parentheses, except in the genus Carex.

\section{Annotated List}

\section{FOLYPODIACEAE. Fern Family}

Polypodium vulgare L. Common polypody. Said to be common in the Upper Peninsula but not yet noticed in Schooleraft County.

Phegopteris polypodioides Fée. (Dryopteris phegopteris (L.) C. Chr.). Long beech-fern. Shaded banks and damp rich woods. Common and often abundant. Fronds triangular.

Phegopteris dryopteris (L.) Fée. (Dryopteris dryoptcris (L.) Britton). Oak fern. Rich shaded ground especially in hardwcods. Fronds ternate. Plentiful.

Adiantum pedatum L. Maidenhair. Rich shaded ground esrecialiy in hardwoods. Frequent. Noticed in particular in woods near indian Lake.

Pteris aquilina I. (Pteridium arqilinum (L.) Kubn.). Common brake. Almost everywhere in diry or damp, open or shaded ground. One of the most common and abundant plants throughout.

Cryptogramma stelleri (Gmel.) Prantl. Slender cliff-brake. At the Pictured Rocks in Alger County. Noticed by the late G. H. Hicks.

Asplenium filix-femina (L.) Bernh. (Athyrium filix-foemina (L.) Roth.). Lady fern. Female fern. Moist shaded ground. Trequent throughout. 
Aspidium thelypteris (L.) Sw. (Iryopteris thelypteris (L.) A. Gray). Marsh shield-fern. Open marshy ground or damp shaded places. Common and often abundant throughout.

Aspidium noveboracense (L.) Sw. (Dryopteris noveboracensis (L.) A. Gray). New York fern. Rich open hardwoods. Abundant in beechmaple-birch woods along the Tahquamenon River in Luce and Chippewa Counties.

Aspidium cristalum (I.) Sw. (Dryopteris cristata (I.) A. Gray). Crested shicld-fern. In damp and swampy places. Frequent.

Aspidium spinulosum (O. F. Müller) Sw. (Dryonteris spinulosa (Muell.) Kuntze). Spinulose shield-fern. Common in hardwoods throughout. In general aprearance much like but generally smaller than the following.

Aspidium spinulosum intermedium (Muhl.) DC. (Dryopteris intermedia (Muhl.) Gray). American shield-tern. In damp rich sharled ground and frequent. Much like the preceding but usually larger.

Cystopteris bulbifera (L.) Bernh. (Filix bulbifera (L.) Underw.) Bulblet cystopteris. In damp sharled ground. Frequent.

Onoclea sensibilis L. Sensitive fern. In moist open or shaded ground. Often abundant.

Onoclea struthiopteris (L.) Hoffm. (Matteuccia struthiopteris Todaro). Ostrich fern. Usually in shaded alluvial ground and hence very abundant along shaded banks of streams. One of the best of our native ferns for cultivation. Grows best in shade and needs plenty of water.

OSMUNDACEAE. Flowering Fern Family

Osmunda regalis L. Royal fern. Flowering fern. Wet open or partially shaded ground. Often abundant.

Osmunda claytoniara L. Clayton's fern. Interrupted fern. I)amp open or partially shaded ground throughout. Fine specimens noticed.

Osmunda cinnamomea L. Cimmamon fern. In damp open or partially shaded ground throughout. Often plentiful.

\section{OPHIOGLOSSACEAE. Adder's Tongue Family}

Rotrychium obliquum Muhl. Ternate grape-fern. Occasional thruughout in open or partially shaded ground. Abundant at Manistique in one place on ground made up of sawdust and bark.

Botrychium virginianum (L.) Sw. Rattlesnake fern. Frequent throughout in rich shaded ground.

\section{EQUISETACEAE. Horsetail Family}

Equisetum arvense L. Common horsetail. Common in open or partially shaded ground and often acting as a sand binder on sandy shores and along raiîway emibankments. 
Equisetum sylvaticum $\mathrm{L}$. Wood horsetail. Common in damp shaded ground.

Eqvisetum fluviatile L. Swamp horsetail. In very wet and muddy open ground or often in shallow water. Common and often abundant.

Equisetum hyemale L. Common scouring rush. In dry open ground and often on sides and crests of sand dunes acting as a fairly efficient sand binder. Noticed in particular east of Manistique on large dunes. See Britton \& Brown's "Illustrated Flora," Second Edition, Volume I, page 41 .

Equisetum variegatum Schleigh. Varigated equisetum. Frequent along the sandy beaches of Lake Michigan and Lake Superior.

Equisetum scirpoides Michx. Sedge-like equisetum. In dryish open or shaded places, but easily overlooked. Frequent.

\section{LYCOPODIACEAE. Club Moss Family}

Lycopodium lucidulum Michx. Shining club-moss. In damp shaded ground. Frequent.

Lycopodium inundatum L. Bog club-moss. In damp sandy open ground. Noticed in particular as abundlant near Manistique, not far from the Lake Michigan shore.

Lycopodium annotinum I. Stiff club-moss. Tsually in shade. Often very abundant in hardwoods. A vine-like evergreen plant.

I.ycopodium clavalum L. Common club-moss. Running pine. Dryish open woods and often very abundant. Noticed in particular as very abundant on the farm of IV. T. S. Cornell near Hiawatha. A beautiful vine-like plant, extensively creeping.

Lycopodium obscurum L. Ground pine. Plentiful in rich woods. Appearing like a small pine shrub and much resembling the following.

Lycopodium obscurum dendroideum (Michx.) D. C. Eaton. Tree-Jike ground pine. In rich woods and apparently the more common form. The difference between these two forms seems very obscure.

Lycopodium complanatum L. Trailing Christmas-green. In dry sancly ground and usually among pines. Often abundant.

Lycopodium tristachyum Pursh. Festoon club-moss. In dry sandy open or partially shaded ground. Abundant in spots. Cornell.

\section{SELAC INELLACEAE. Selaginella Family}

Selaginella apus (L.) Spring. Creeping selaginella. In low damp open or partially shaded places. Often abundant. A very pretty little moss-like plant.

TAXACEAE. Yew Family

Tarus canadensis Narsh. American yew. Ground hemlock. In tamarack-black spruce amps and often very abundant in hardwoods. 


\section{PINACEAE. Pine Family}

Pinus strobus L. White pine. Formerly abundant in many localities as at present indicated by stumps. A very few clumps of large trees left. Small trees noticed throughout.

Pinus banksiana Lamb. Jack pine. Plentiful on what are called jack pine plains, consisting of very dry sandy localities of flat or rolling ground. Noticed also in sphagnum swamps. Usually a small scraggy tree, occasionally large and straight enough for lumber.

Pinus sylvestris L. Scotch pine. Occasionally planted. Noticed in particular on the sandy beach of Grand Island in Alger County where it appears to be thriving.

Pinus resinosa Ait. Red pine. Norway pine. Tormerly abundant on dry sandy land. Has been extensively cut for lumber and only a few small tracts now left. Small trees common throughout.

Larix laricina (Du Roi) Koch. Tamarack. Abundant in "tamarack swamps" and occasional on dry land. Usually small and mixed with black spruce. It is being killed by attacks of the saw-fly, an insect pest from Europe. Shrubs plesitiful throughout.

Picea canadensis (Mill.) BSSP. White spruce. Frequent on dryish high ground but never plentiful. Many large trees noticed on the banks of the Tahquamenon River. in Luce County. Often attacked by the dwarf mistletue as a parasite.

Picea mariana (Mill.) BSP. Black spruce. Common throughout with tamarack in what are often called tamarack-black spruce swamps. Usually the trees are small and often attacked by the dwarf mistletoe. Many botanists, foresters and cruisers distinguish a small short-leaved form and call it "swamp spruce," Picen brevifolia Peck.

Abies talsamen (I..) Mill. Balsam. Balsam fir. Usually in and on borders of hardwoods, occasional in swamps. Noticed throughout.

Tsuga canadensis (I..) Carr. Hemlock. In hardwoods, many seattering large trecs noticed. Sometimes plentiful in spots and streaks, but seldom abundant.

Thuja orcidentalis L. White cedar. Arbor vitae. Formerly quite abundant in "cedar swamps," but at present scarce on account of lumbering and forest fires. Oecasional on poor sandy ground and in hardwoods. Small trees also common along lake shores.

Juniperus communis depressa Pursh. Low juniper. Often plentiful along the shores and sandy beaches of Lake Michigan and Lake Superior where it acts as an efficient sand binder. Occasional in other places in dry sandy ground.

Juniperus horizontalis Moench. Creeping juniper. Frequent and sometimes abundant along the sandy beaches and shores of Lake Michigan and Lake Superior where it often covers the ground and acts as an efficient sand binder. Occasional in swamps. 
TYPHACEAE. Cat-tail Family

Typha latifolia L. Common cat-tail. Cat-tail flag. Common throughout in open swampy places.

SPARGANIACEAE. Bur-reed Family

Sparganium eurycarpum Engelm. Broad-fruited bur-reed. Borders of small lakes, ponds and streams. Abundant.

Sparganium diversifolium acanle (Beeby) Fernald \& Eames. Stemless bur-reed. In very wet open swampy places. Often abundant.

NAJADACEAE. Pondweed Family

Potamogeton natans I. Common floating pondweed. In ponds, on borders of small lakes, on margins and in coves of streams. Often abundant.

Potamogeton epihydrus Raf. Nuttall's pondweed. In still or Howing water throughout. Often abundant.

Potsmogeton amplifolius Tuckerm. Large-leaved pondweed. In ponds and slow streams throughout. Often plentiful.

Potamogeton helerophyllus Schreb. Various-leaved pondweer!. In ponds and slow streams throughout. Frequent.

Potamogeton angustifolius Berchtold \& Presl. Ziz's pondweed. In ponds and small lakes and on margins of slow streams throughout. Plentiful.

Polamogeton perfoliutus L. Clasping-leaved pondweed. In ponds and slow streams throughout. Often plentiful.

Potamogeton pusillus L. Small pondweed. In ponds and ditches. Common.

Potamogeton foliosus Raf. Leafy pondweed. In still and slow-flowing water throughout. Plentiful.

Potamogeton dimorphus Raf. Spiral pondweed. In still water and on borders of slow streams. Plentiful.

Najas flexilis (Willd.) Rostk. \& Schmidt. Slender naias. In ponds and slow streams. Often abundant.

JUNCAGINACEAE. Arrow Grass Family

Scheuchzeria palustris I. Scheuchzeria. Open boggy places throughout. Noticed in particular near Yermilion in Chippewa County.

Triglochin muritima L. Sea-side arrow-grass. Marshy open places throughout. Plentiful.

Triglochin palustris L. Marsh arrow-grass. Usually in damp open sandy ground. Often abundant in damp sand along lake shores. 
ALISMACEAE. Water-plantain Family

Sagittaria latifolia Willd. Broad-leaved arrow-head. In ditches, muddy places, shallow water about ponds, and along streams. Plentiful.

Alisma plantago-aquatica L. American water-plantain. In shallow water, muddy places, and along streams. Often abundant.

\section{HYDROCHARITACEAE. Frog's-bit Family}

Elorea canadensis Michx. Waterweed. In rlitches, coves, ponds, small lakes and along slow streams. Often abundant.

Vallisneria spiralis L. Tape grass. Wild celery. In ponds and slow streams. Abundant. Said to be a fine duck food.

\section{GRAMINEAE. Grass Family}

Digitaria humifusa Pers. (Syntherisma ischacmum (Schreb. (Nash). Small crab-grass. Occasional on poor sandy ground, in cultivated fields and waste places. A weed but not very troublesome. Usually prostrate.

Digitaria sanguinalis (L.) Scop. (Syntherisma sanguinale (L.) Dulac.), Large crab-grass. Finger-grass. A miserable weed in cities and villages. gardens, fields and waste places.

Panicum capillare L. Old-witch grass. Usually preferring dry sandly ground. Common as a weed about cities and villages, in gardens, fields. and waste places.

Panicum depauperatum Muhl. Starved panic-grass. In dry open ground. Apparently infrequent.

Panicum subvillosum Ashe. Spreading panic-grass. Along or near sandy beaches of Lake Michigan and Lake Superior and on dry open ground throughout. Frequent.

Echinochloa crusgalli (I.) Beauv. Barnyard-grass. Summer-grass. Usually preferring damp cultivated grounds, but as a weed will be found in most all gardens, fields and waste places. Very variable.

Setaria glauca (L.) Beauv. (Chactochloa glauca (L.) Scribn.). Yellow foxtail. Pigeon-grass. A common weed in almost all cultivated grounck. In general appearance much like the following.

Seturia viridis (I.) Beauv. (Chaetochloa viridis (L.) Scribn.). Cirecul foxtail. Frequent in cultivated grounds and waste places. Much like the preceding in general appearance.

Cenchrus carolinianus Walt. Small bur-grass. Usually in dry sancly open ground and gradually becoming more frequent. A miserable weed with a cruel spiny bur and often called sand-bur.

Zizania palustris L. Indian rice. Wild rice. In ponds, small lakes and streams, apparently planted by sportsmen to attract ducks. Abundant in the Tahquamenon River in Luce County. 
Phalaris arundinacea L. Peed canary-grass. In wet open ground. Common throughout.

Hierochloë odorata (L.) Wahlenb. (Savastana odorata (L.) Scribn.). Vanilla grass. Sweet-grass. Moist open or partially shaded ground near Seul Choix. Plentiful. Cornell. Also noticerl near Rexton in Mackinac County. It emits a very sweet fragrance.

Milium effusum L. Tall millet-grass. Frequent throughout in rich woods.

Oryzopsis pungens (Torr.) Hitche. Slender mountain rice. In dry and sterile open ground. Plentiful.

Oryzopsis asperifolia Michx. White-grained mountain rice. On borders, and in open spots of beech-maple-birch wood's. Frequent.

Muhlenbergia racemosa (Michx.) BSP. Wild timothy. On low meadow-like ground and borders of marshes. Frequent.

Brachyelytrum erectum (Schreb.) Beauv. Bearded short-husk. Common throughout in hardwoods.

Phleum pratense I. Timothy. Common throughout, probably as an escape.

Sporobolus uniflorus (Muhl.) Scribn. \& Merr. Late-flowering dropseed. In damp open sandy ground west of Manistique. Abundant.

Agrostis alba L. Redtop. In damp open ground and often in damp sand. Common.

Agrostis hyemalis (Walt.) BSP. Rough hair-grass. Fool-hay. In dry or moist open or partially shaded ground. Aburedant.

Agrostis perennans (Walt.) Tuckerm. Thin-grass. Lpland bentgrass. Usually in damp rich shaded ground. Plentiful.

Calamovilfa longifolia (Hook.) Hack. Long-leaved reerl-ngass. On sand dunes and sandy beaches. Apparently seldom abundant in this region. When growing in abundance it is an efficient sanrl binder.

Calamagrostis canadensis (Michx.) Beauv. Blue-joint grass. Usually in wet open meadow-like ground. Often abundant and cut for hay.

Ammophila arenaria (I.) Link. Sea sand-reed. Sanciy beaches of - Lake Nichigan and Lake Superior. Often abundant, when it is one of the most efficient sand binders known.

Deschampsia flexuosa (L.) Trin. Common hair-grass. Dry open ground throughout. Often plentiful.

Deschampsia caespitosa (L.) Beauv. Tufted hair-grass. Frequent in wet open ground. Noticed in particular in wet places on Bois Blane Island in Mackinac County.

Avena sativa I. Common oat. Apparently escaping and persisting in waste places.

Danthonia spicata (I.) Beauv. Common wild oat-grass. In dry open sterile ground throughout. Plentiful. 
Danthonia compressa Aust. Flattened wild oat-grass. Dry open ground near Floodwood. Plentiful.

Danthonia intermedia Vasey. Vasey's wild oat-grass. Dry open ground near Floodweod. Plentiful.

Phragmites communis Trin. Commnn reed-grass. Wet open places, borders of tamarack-black spruce swamps, and near lake shores. Seldom abundant.

Melica smithii (Porter) Vasey. (Avena smithii Porter). Smith's oat. Damp open woods. Apparently infrequent.

Melica striata (Mich.) Hitche. (Anena torreyi Nash). I'urple oat. Open woods. Apparently infrequent.

Dactylis glomerata L. Orchard grass. Ahout cities and villages and in cultivated grounds. Frequent.

Poa annua L. Low spear-grass. In lawns and cultivated grounds. Common.

Poa compressa I. Canada hlue-grass. Fnglish blue-grass. Usually in diry and sterile cultivated ground. Noticed as frequent on the sandy beach of Lake Michigan.

Poa nemoralis I. Wood meadow-grass. Dry open ground. Apparently infrequent.

Joa pratensis L. June grass. Kentucky blue-grass. The common grass of our lawns, fields, meadows, pastures, and open woodlands.

Poa trivialis 1. Rough-stalked meadow-grass. Damp open ground near Floodwood. Apparently rare.

Glyceria canarlensis (Michx.) Trin. (Panicularia canadensis (Michx.) Kuntzc). Rattlesnake-grass. Wet boggy open places. Common and often abundant. A beautiful grass.

Glyceria nervata (Willd.) Trin. (Panicularia nervata (Willd.) Kuntze). Fowl meadow-grass. Low open or partially shaded ground. Common and often abundant.

Glyceria grandis Wats. (Panicularia grandis (S. Wats.) Nash). Reed meadow-grass. Low banks of streams, ditches and wet meadow-like ground. Frequent.

F'estuca octoflora Walt. Slender fescue-grass. In dry sterile open ground. Frequent.

Festuca ovina I. Sheep's fescue. In open dry ground. Frequent.

Festuca elatior L. Meadow-fescue. In an open dryish place near Floodwood. Apparently infrequent.

Festuca nulans Spreng. Nodding fescue-grass. Sandy beach of Lake Michigan near Manistique. Apparently infrequent.

Bromus secalinus $\mathrm{I}_{\text {. }}$ Common chess. About cities and villages and in cultivated grounds. Frequent.

Bromus ciliatus L. Fringed brome-grass. ()pen moist wonds and banks of streams. Frequent. 
Bromus pumpellianus melicoides Shear. Pumpelly's melic-like brome grass. A western form plentiful on the sandy beach at Mackinaw City in Chehoygan County. It will probably be iound in the Northern Peninsula.

Agropyron repens (L.) Beauv. Quack-grass. Common as a weed in cities and villages and cultivated grounds.

Agropyron dasystachyum (Hook.) Scribn. Northern wheat-grass. Sandy beaches of Lake Michigan and Lake Superior. When abundant it is a good sand binder.

Agropyrum tenerum Vasey. Slender wheat-grass. On the sandy beach of Grand Island near Munising in Alger County. Plentiful. Perhaps the identification is doubtful.

Agropyron caninum (L.) Beauv. Awned wheat-grass. Open dryish ground on Grand Island near Munising in Alger County. Plentiful.

Secale cereale L. Common rye. Escaping from cultivation and apparently persisting in cities, villages and cultivated grouncls.

Hordeum jubatum L. Squirrel-tail grass. Plentiful in cities and villages and occasional in damp meadow-like ground.

Elymus virginicus L. Virginia wild rye. I'lentiful along low shaded banks of streams and in damp open woods.

Elymus canadensis L. Nodding wild rye. Sandy beaches of Lake Michigan and Lake Superior. Frequent. Acts as a good sand binder.

Hystrix patula Moench. Bottle-brush grass. Frequent in beechmaple-birch woods.

CYPERACEAE. Sedge Family

Dutichium arundinaceum (L.) Britton. Dulichium. Wet open swampy places and on borders of ponds. Often abundant.

Eleocharis palustris (I..) R.\& S. Creeping spike-rush. Wet meadowlike ground and often in shallow water. Common.

Eleocharis palustiis vigens Bailey. Large spike-rush. Margins of ponds and small lakes and usually in shallow water. Often abundant.

Eleocharis acicularis (I.) R. \& S. Needle spike-rush. Wet and muddy places about ponds, small lakes, and along low banks of slow streams. Often abundant.

Eleocharis tenuis (Willd.) Schultes. Slender spike-rush. Wet open meadow-like ground. Abundant.

Scirpus pauciflorus Iightf. Few-flowered club-rush. Wet open calcareous ground near Lake Michigan shore. Often abundant.

Scirpus caespitosus L. Tufted club-rush. Deer-hair. Wet boggy open ground on margin of a tamarack-black spruce swamp south of Shingleton. Plentiful.

Scirpus hudsonianus (Michx.) Fernald. (Eriophorum alpinum L.). Alpine cotton-grass. Wet open marshy ground. Often abundant. 
Scirpus americanus Pers. Three-square. Borders of ponds, small lakes and streams. Plentiful.

Scirpus validus Vahl. Great bulrush. Margins of ponds and streams. Plentiful.

Scirpus occidentalis (Wats.) Chase. Vicid great bulrush. Wet boggy places and in shallow water about ponds, small lakes, bays of the Great Lakes and along streams. Abundant.

Scirpus atrovirens Muhl. Dark-green bulrush. In marshy open places and swamps. Common.

Scirpus cyperinus pelius Fernald. Wool grass. In wet open prairielike ground. Common.

Scirpus atrocinctus Fernald. Dark wool-grass. Wet open or partially shaded ground. Frequent.

Scirpus atrocinctus brachypodus Fernald. Clustered wool-grass. Damp open or partially shaded ground. Frequent.

Eriophorum callitrix Cham. Hare's-tail. Open bogs. Common.

Eriophorum gracile Roth. Slender cotton-grass. Swamps and open boggy places. Frequent.

Eriophorum tenellum Nutt. Rough cotton-grass. Open wet and swampy places. Frequent.

Eriophorum angustifolium Roth. Tall-cotton-grass. Very wet boggy places and often growing in water. Noticed as plentiful near Floodwood.

Eriophorum viridi-carinatum (Engelm.) Fernalr. Thin-leaved cotton grass. Borders of, and open spots in, tamarack-black spruce swamps. Common.

Eriophorum virginicum I. Virginia cotton-grass. Open bogs and very wet mearlow-like ground. Common.

Rynchospora fusca (I..) Ait.f. Brown beaked-rush. Damp prairie-like or open boggy ground near Manistique. Plentiful. Prof. C. A. Davis, 1905.

Rynchospora alba (L.) Vahl. White beaked-rush. Wet boggy open ground. Often abundant.

Cladium mariscoides (Muhl.) Torr. (Mariscus mariscoides (Muhl.) Kuntze). Twig-rush. Bogs, wet open marshy places and wet shores. Often abundant.

Carex crawfordii Fernald. Crawford's sedge. Dryish open ground. Plentiful.

Carex albolutescens Schwein. Grecnish-white serlge. Damp or dryish open ground near Manistique. Plentiful.

Carex normalis Mackenzie. (C. mirabilis Dewey). Lager straw sedge. Dryish open or partially shaded ground. Frequent.

Carex tenera Dewey. Straw sedge. Frequent in dryish open or partially shaded ground.

Carex bebbii Olney. Bebb's sedge. Low open ground. Frequent. 
Carex renea Fernald. Fernald's hay-sedge. Dryish open or partially shaded ground. Frequent and often plentiful.

Carex cephalantha (Bailey) Bicknell. (C. stellulata cophalantha (Bailey) Fernald). Larger prickly sedge. Low open ground near Floodwood. Plentiful.

Carex leersii angustata (Carey) Mackenzie. (C. stellulata angustata Carey). Tapering sedge. Low open ground at Floodwood. Plentiful. Carex steritis Willd. (C. scirpoides Schk.). Prickly sedge. Damp open ground near Manistique. Plentiful.

Carex interior Bailey. Inland sedge. Damp or wet open ground. Plentiful throughout.

Carcx arcta Boott. Northern elustered sedge. In damp woods at Floodwood. Iirequent.

Carex canescens L. Silvery sedge. Wet open places about tamarackblack spruce swamps. Plentiful.

Carex brunnescens Poir. Brownish sedge. Dryish shaded ground at Floodwood. Plentiful.

Carex bromoides Schkuhr. Brome-like sedge. Frequent in damp woods.

Carex deweyana Schwein. Dewey's sedge. Beech-maple-ibirch-woods. Plentiful.

Carex trispcrma Dewey. Three-fruited sedge. Plentiful in tamarackblack spruce swamps.

Carex disperma Dewey. (C. tenella Schkuhr.). Soft-leaved sedge. In damp woods, especially in and about tamarack-black spruce swamps. Plentiful.

Carex diandra Schrank. Lesser panicled sedge. Bogs and damp open places at Floodwood. Plentiful.

Carex stipata Muhl. Awl-fruited sedge. Very wet open places. Common throughout.

Carex sartwellii Dewey. Sartwell's sedge. Very wet open boggy places near Manistique. Plentiful.

Carex crinita Lam. Fringed sedge. Wet open or partially shaded ground. Common throughout.

Carex gynandra Schwein. (C. crinita gynandra (Schwein.) Schwein. \& Torr.). Nodding sedge. Wet open or partially shaded ground near Manistique. Frequent.

Carex aquatilis substricta Kükenthal. Northern water sedge. In very wet open ground throughout. Common.

Carex stricta Lam. Tussock sedge. Very wet open or partially shaded ground forming dense bunches or tussocks.

Carex strictior Dewey. Stiff sedge. Open marshy ground near Floodwood. F'requent. Much resembling the preceding but not forming large tufts or tussocks. 
Carex aurea Nutt. Golden-fruited sedge. Damp open ground, usually in grassy places. Common.

Carex hassei Bailey. Hasse's sedge. On the damp gravelly beach of Lake Michigan near Manistique. By some authors considered the same as C. bicolor All.

Carex panciflora Lightf. Few-flowered sedge. In open spots of tamarack-black spruce swamps in sphagnum. Often very abundant.

Carex leptalea Wahlenb. Bristle-stalked sedge. In bogs and swamps. Abundant throughout.

Carex buxbaumii Wahl. (C. polygama Schkuhr.). Brown sedge. Common in boggy open places.

Carex gracillima Schwein. Graceful sedge. Conmon in hardwoods.

Carex tonsa (Fernald) Bicknell. (C. umbellata tonsa Fernald). Deep green sedge. On high fixed sand ridges near Floodwood. Apparently infrequent.

Carex pennsylvanica Lam. Pennsylvania sedge. Dry sandy open ground. Common throughout.

Carex paupercula Michx. Bog sedge. Frequent in open bogs throughout. Noticed in particular about Floodwood.

Carex leptonervia Fernald. (C. laxiflora ieptoneria Fernald). Twoedged sedge. Rich shaded ground. Plentiful throughout.

Carex flava L. Yellow sedge. Wet open marshy ground. Often abundant.

Carex cryptolepis Mackenzie. ("C. Alava rectirostra Gaudin"). Smaller yellow sedge. Marshy open ground. Frequent.

Carex eederi Retz. Creen sedge. Damp open sarudy ground near Lake Michigan shore. Abundant.

Carex capillaris elongata Olney. Tall hair-like sedge. In wet shaded ground near Manistique. Plentiful.

Carex arctata Boott. Drooping wood-sedge. In hardwoods. Frequent throughout.

Carex flexuosa Muhl. (C. debilis rudgei Bailey). Slender-stalked sedge. Frequent in hardwoods about Floodwood.

Carex scabrata Schwein. Kough sedge. Damp open or partially shaded ground on Grand Island in Alger County. Plentiful.

Carex lasiocarpa Ehrh. (C. filiformis Good). Slender sedge. In bogs and often in shallow water. Abundant.

C'arex oligosperma Michx. Few-sceded serlge. Open bogs throughout. Often abundant.

Carex lacustris Willd. (C. riparia Muhl.). Lake-bank sedge. In swamps about Floodwood. Plentiful.

Carex pseudo-cyperus I. Cyperus-like sedge. Wet open ground throughout. Frequent. 
Carex hystricina Muhl. Porcupine sedge. Wet boggy open ground. Often abundant.

Carex retrorsa Schwein. Retrorse sedge. Wet open or partially shaded ground. Plentiful throughout.

Carex lupulina Muhl. Hop sedge. Swamps and wet woods. Common.

Carex intumescens Rudge. Bladder sedge. Wet open or partially shaded ground. Common throughout.

Carex monile Tuckerm (C. vesicaria monile (Tuckerm.) Fernald). Necklace sedge. Open wet places at Floodwood. Plentiful.

Carex tuckermani Dewey. Tuckerman's sedge. liich open ground. Plentiful throughout.

ARACEAE. Arum Family.

Arisaema triphyllum (L.) Schott. Indian turnip. Jack-in-the-pulpit. Rich woods, especially hardwoods. Common.

Calla palustris L. Wild calla. In ditches and very wet boggy places. Often abundant.

Acorus calamus L. Swcet flag. ()n horders of slow streams. Trequent.

\section{LEMNACEAE. Duckweed Family}

I.emna minor L. I.esser duckweed. Often covering stagnant water in ditches, on and near margins of ponds, small lakes and slow streams. Abundant. Appearing like a green seum on water.

\section{PONTEDERIACEAE. Pickerel-weed Family}

Pontederia cordata L. Pickerel-weed. In ponds, small lakes, coves, bays and on margins of slow strearns. Noticed in particular along the Tahquamenon River in Iuce County. Plentiful.

\section{JUNCACEAE. Rush Family}

Juncus bufonius L. Toad rush. Damp open ground, often in wet sand and on readsides. Abundant.

Juncus tenuis Willd. Slender rush. Dainp fields, open places and roadsides. Common.

Juncus greenei Oakes \& Tuckerm. Greene's rush. In wrt sand near Manistique. Plentifu!. Prof. ('. A. Davis, 1905.

Juncus balticus littoralis Engelm. Baltic rush. Damp open ground and on sandy beaches, where it is an efficient sand binder. Abundant.

Juncus effusus I. Common rush. Soft rush. Wet open ground. ('ornmons.

Juncus brachycephatus (Engelm.) Buchenau. Smali-headed rush. Wet shores of Lale Nichigan and in open marshy places. Plentiful. 
Juncus brevicandatus (Engelm.) Fernal!. Narrow-panicled rush. Wet and muddy places about ponds, small lakes and along low banks of slow streams. Plentiful.

Juncus canadensis J. Gay. Canada rush. Open marshy places. Frequent.

Juncus nodosus L. Knotted rush. Damp gravelly places along and near Lake' Michigan shore. Often abundant.

\section{LILIACEAE. Lily Family}

Tofieldia glutinosa (Michx.) Pers. Glutinous tofieldia. Damp open prairie-like ground. Plentiful.

Zygadenus chloranthus Richards. (Anticlea elegans (Pursh) Ryclh.). Glaucous zygadenus. Sand dunes and sandy beaches of Lake Michigan near Manistique. Often plentiful.

Allium tricoccum Ait. Wild leek. In hardwoods and often abundant. Cornell.

Lilium philadelphicum andinum (Nutt.) Ker. (L. umbellatum Pursh). Western red lily. Rich partially shaded and open dryish sandy ground. Frequent.

Erythronium albidum Nutt. White adder's-tongue. Rich usually shaded ground. Frequent. Cornell.

A sparagus officina?is L. Garden asparagus. Occasional as an escape in dry sandy open ground.

Clintonia borealis (Ait.) Raf. Yellow clintonia. Tamarack-black spruce swamps and in hardwoods. Often very abundant.

Smilacina racemosa (L.) Desf. (Vagnera racemosa (L.) Morong.). False-spikenard. Rich open woods. Often plentiful.

Smilacina stellata (L.) Desf. (Vagnera stellata (I.) Morong.). Starflowered Solomon's seal. Moist shaderl ground and also in dry sandy open or shaded places. Often abundant.

Smilacina trifolia (L.) Desf. (Vagnera trifolia (L.) Morong.). Threeleaved Solomon's seal. Very wet open boggy places. Often abundant.

Maianthemum canadense Desf. (Unifolium canadense (Desf.) Greene). Wild lily-of-the-valley. Damp or dryish shaderl ground. Abundant in hardwoods.

Streptopus amplexifolius (L.) DC. Clasping-leaved twisted-stalk. Damp rich open or shaded ground. Often plentiful.

Polygonatum biflorum (Walt.) Ell. Small Solomon's seal. Frequent in hardwoods.

Medeola virginiana L. Indian cucumber-root. Rich open woods. Frequent.

Trillium grandiflorum (Michx.) Salisb. Large-flowered wake-robin. In hardwoods but seldom plentiful.

Trillium cernuum I. Nodding wake-robin. In hardwoods. Frequent. 


\section{IRIDACEAE. Iris Family}

Iris versicolor L. Larger blue-flag. Damp open or shaded ground. Seldom abundant.

Sisyrinchium angustifolium Mill. Pointed blue-eyed grass. On and near the sandy beach of Lake Michigan. Apparently infrequent.

\section{ORCHIDACEAE. Orchis Family}

Cypripedium parviflorum Salisb. Smaller yellow lady's slipper. Damp rich or swampy shaded ground. Apparently not common.

Cypripedium parviflorum pubescens (Willd.) Knight. Larger yellow lady's slipper. Damp places in hardwoods. Frequent.

Cypripedium candidum Muhl. Small white lady's slipper. Swampy ground near Manistique. Plentiful. W. T. S. Cornell.

Cypripedium hirsutum Mill. (C. reginae Walt.). Showy lady's slipper. Swampy ground and margin of wet woods. Apparently infrequent.

Cypripedium acaule Ait. (Fissipes acaulis (Ait.) Small). Stemless lady's slipper. In tamarack-black spruce swamps or shaded sandy ground. Seldom abundant.

Habenaria bracteata (Willd.) R. Br. (Coeloglossum bracteatum (Willd.) Parl.). Long-bracted orchis. Frequent in hardwoods.

Habenaria hyperborea (L.) R. Br. (Limnorchis hyperborea (L.) Rydb.). Tall leafy green orchis. Frequent in open hardwoods.

Habenaria dilatata (Pursh) Gray. (Limnorchis dilatata (Pursh) Rydb.). Tall white bog orchis. Bogs and often in wet sand. Frequent and often plentiful.

Ilabenaria obtusata (Pursh) Richards. (Lysiella obtusata (Pursh) Richards). Small northern bog orchis. Tamarack-black spruce swamps and also in other very low wet shaded places. Apparently not common.

Habenaria hookeri Torr. (Lysias hookeriana (A. Gray) Rydb.). Hooker's orchis. Noticed as occasional in hardwoods.

Habenaria orbiculata (Pursh) Torr. (Lysias orbiculata (Pursh) Rydb.). Round-leaved orchis. Noticed in hardwoods. Apparently infrequent.

Habenaria macrophylla Goldie. Large round-leaved orchis. Rich shaded ground. Apparently infrequent.

Pogonia ophioglossoides (L.) Ker. Rose pogonia. In open boggy places. Frequent.

Calopogon pulchellus (Sw.) R. Br. (Limodorum tuberosum L.). Grass pink. Open boggy places. (iften plentiful.

Arethusa bulbosa $\mathrm{L}_{2}$ Arethusa. Wild pink. Very wet and boggy open places near tamarack-black spruce swamps. Never abundant.

Spiranthes gracilis (Bigel.) Beck. (Ibidium gracile (Bigel.) House). Slender ladies' tresses. Dry open ground near Manistique. Apparently infrequent. Very probably overlooked. 
Spiranthes cernua (L.) Richard. (Ibidium cernuum (I..) House). Drooping ladies' tresses. Damp open ground. A bundant near Manistique in damp sand.

Epipactis tesselata (Lodd.) A. A. Eaton. (Peramium tesselatum (Lodd.) Heller). Checkered rattlesnake plantain. Occasional in open hardwoods. Epipactis decipiens (Hook.) Ames. (Peramium decipiens (Hook.) Piper). Menzies' rattlesnake plantain. Dryish shaded ground. Froquent. Cornell.

Listera convallarioides (Sw.) Torr. (Ophrys convallarioides (Sw.) IV. F. Wight). Broad-lipped twayblade. Very wet woods near Floodwoor. Apparently infrequent. Very probably overlooked.

Corallorrhiza trifida Chatelain. (C. corallorrhiza (L.) Karst.). Early coral-root. Damp shaded places. Frequent.

Corallorrhiza maculata Raf. Large coral-root. Frequent in hardwoods.

Calypso bulbosa (L.) Oakes. (Cytherea hulbosa (L.) House). Calypso. Rich shaded ground. Occasional. W. T. S. Cornell.

SALICACEAE. Willow Family

Salix nigra Marsh. Black willow. Borders of damp woods and along streams as a small shrub. Frequent.

Salix lucida Muhl. Shining willow. Common in wet open ground.

Salix serissima (Bailey) Fernald. Autumn willow. Borders of tamarack-black spruce swamps, especially near Manistique. Plentiful. Cornell.

Salix alba L. White willow. Occasionally planted but apparently not spreading.

Salix longifolia Muhl. (Salix interior Rowlee). Sandbar willow. Along streams. Frequent.

Salix cordata Muhl. Heart-leaved willow. Frequent along streams.

Salix glaucophylla Bebb. Broad-leaved willow. On and near the sandy beaches of Lake Huron and Lake Superior. Frequent.

Salix syrticola Fernald. (S. adenophylla Hook.). Furry willow. On and near the sandy beaches of Lake Michigan and Lake Superior. Frequent.

Salix pedicellaris Pursh. Bog willow. Very wet and boggy places. Often abundant.

Salix discolor Muhl. Pussy willow. Low open ground and along banks of streams. Frequent.

Salix petiolaris Sm. Slender willow. In damp low ground. Often abundant.

Salix humitis Marsh. Prairie willow. Dry open ground. Often plentiful. 
Salix rostrata Richards. (S. bebbiana Sarg.). Beaked willow. Dry or damp open ground. Plentiful.

Salix candida Flügge. Hoary willow. Very wet or boggy open ground. Common.

Salix pellita Anders. Satiny willow. Along the low marshy banks of the Tahquamenon River in Iuce County. Abundant.

Populus alba L. White poplar. Occasionally planted, but apparently not spreading.

Populus tremuloides Michx. American aspen. Throughout, but seldom abundant.

Populus granciulentata Michx. Large-toothed aspen. Rich woods with other trees. Never plentiful.

Populus balsamifera L. Balsam pop!ar. Trees often large and extend to the south shore of I ake Superior. Plentiful.

Populus deltoides Marsh. Cottonwood. A hurticultural form called Carolina poplar, or large-leaved poplar, occasionally planted as an ornamental tree, but apparently not spreading.

Populus nigra italica Du Roi. Lombardy poplar. Occasionally planted but not sprearling:

MYRICACEAE. Sweet Gale Family

Myrica gale $\mathrm{L}$. Sweet gair. In very wet places, on borders of ponds and small lakes and along streams. Often very abundant.

Myrica asplenifolia L. (Comptonia peregiina (I.) Coulter). Sweet fern. Open dry sterile ground. Often very abundant.

\section{JUGLANDACEAE. Walnut Family}

Juglans cinerea L. Butternut. Reported as occasionally planted. Large native trees noticed on Bois Blanc Island in Mackinae County, very probably its northern limit in the eastern counties of the Upper Peninsula.

Juglans nigra L. Black wahnut. Reported as frequently planted and said to thrive.

\section{BETULACEAE. Birch Family}

Corylus rostrata Ait. Beaker hazelnut. Dryish open or partially shaded ground. Common and often abundant.

Ostrya virginiana (Mill.) K. Koch. Ironwood. In hardwoods with other trees. Plentiful.

Betula lutea Michx.f. Yellow birch. One of the three principal trees of the hardwood forests. Common with beech and sugar maple. Large shaggy-barked ones often called "red birch." It extends to the south shore of Lake Superior. 
Betula alba papyrifera (Marsh.) Spach. (B. papyrifera Marsh.). Paper birch. Canoe birch. White birch. Common in hardwoods and also along streams. Small trees and mere shrubs often abundant on burned over ground. It extends to the south shore of Lake Superior.

Betula pumila glandulifera Regel (B. glandulifera (Regel) Butler). Glandular low birch. Borders of tamarack-black spruce swamps, and in other swampy places. Often abundant.

Alnus crispa (Ait.) Pursh. (A. alnobetula (Ehrh.) K. Koch). Green alder. Mountain alder. Sand dunes near Manistique. Plentiful. Prof. C. A. Davis, 1905 .

Alnus incana. (L.) Moench. Speckled alder. In swamps, all wet low places and along streams. Very abundant.

FAGACEAE. Beech Family

Fagus grandifolia Ehrh. American beech. One of the three principal trees of the hardwood forests. Abundant with sugar maple and yellow birch. It extends to the south shore of Iake Superior.

Quercus macrocarpa Michx. Bur oak. Frequent along the Mani:tique River in Schoolcraft County and the Tahquamenon River in Luce County. In the lumber trade sold as white oak.

Quercus bicolor Willd. Swamp white oak. Occasional along the two rivers above mentioned. Known as blue oak in Schoolcraft County and in the lumber trade sold as white oak.

Quercus rubra L. Ped oak. On dry sandy ground throughout, especially on jack pine plains. Often plentifu! but seldom large.

\section{URTICACEAE. Nettle Family}

Clmus fulva Michx. Slippery elm. Red elm. Reported as occasional in Schoolcraft County by IV. T. S. Cornell and in Alger County by Thomas B. Wyman, forester at Numising. Not seen by the writer.

Ulmus americana $\mathrm{L}$. American elm. White elm. Frequent throughout, and fine large trees noticed in hardwoods and along the large streams. It extends to the south shore of Lake Superior.

Cannabis sativa $\mathrm{L}$. Hemp. Occasional about cities and villages as a weed.

Humulus lupulus L. Common hop. Occasionally escaping and persisting.

Urtica gracilis Ait. Slender nettle. Damp open or partially shaded ground. Frequent throughout.

Laportea canadensis (I..) Gaud. (Crticastrum divaricatum (L.) Kuntze). Wood nettle. Frequent in hardwoods.

SANTALACEAE. Sandalwond Tamily

Comandra richardsiana Fernald. Richards" comandra. Dry open or 
partially shaded ground. Common. By some authors included in $C$. umbellata (L.) Nutt.

Comandra livida Richards. Northern comandra. In dry sterile open or shaded ground. Apparently infrequent.

\section{LORANTHACEAE. Mistletoe Family}

Arceuthobium pusillum Peck. (Razoumofskya pusilla (Peck) Kuntze). Dwarf mistletoe. Parasitic on the twigs of white spruce and black spruce causing them to curl up into thick bunches, forming what are called "witches' brooms." Frequent.

\section{POLYGONACEAE. Buckwheat Family}

Rumex britannica L. Great water dock. In wet marshy places throughout. Common.

Rumex crispus L. Yellow dock. About cities and villages and in cultivated grounds. A miserable weed.

Rumex mexicanus Meisn. Willow-leaved dock. Sandy beaches of Lake Michigan and in dry open ground thronghout. Frequent.

Rumex obtusifolius L. Bitter dock. Frequent in cities, villages, and cultivated grounds as a weed.

Rumex acetosella L. Field sorrel. Common in cultivated grounds.

Polygonum aviculare L. Knot-grass. Common about cities and villages, in lawns, gardens, and other cultivated grounds.

Polygonum erectum L. Erect knotweed. Mostly about cities and villages, and on roadsides as a weed. Trequent.

Polygonum lapathifolium L. (Persicaria lapathifolia (L.) S. F. Gray). Pale persicaria. In damp open ground. Noticed mostly as an occasional weed about cities and villages.

Polygonum amphibium L. (Persicaria amphibia (L.) S. F. Gray). Water persicaria. Margins of ponds, small lakes, and along low banks of streams. Plentiful.

Polygonum muhlenbergii (Meisn.) Wats. (Persicaria muhlenbergii (S. Wats.) Small.). Swamp persicaria. Marshy and swampy places, margins of ponds and along streams. Often in shallow water. Common.

Polygonum hydropiper L. (Persicaria hydropiper (I..) Opiz.) Smartweed. In damp open or partially shaded ground. Plentiful.

Polygonum acre HBK. (Persicaria punctata (Ell.) Small.). Water smartweed. Wet marshy ground and along low banks of streams and occasionally in shallow water. Plentiful.

Polygonum persicaria L. (Persicaria persicaria (I..) Small.) Lady's thumb. Usually in damp open places as a weed in citics and villages. Frequent.

Folygonum sagittatum L. (Tracaulon sagittatum (L.) Small.). Arrowleaved tear-thumb. Tamp open or partially shaded ground. Frequent. 
Polygonum convolvulus L. (Tiniaria convolvulus (I..) Webb \& Moq.). Black bindweed. As a frequent weed in gardens and other cultivated grounds.

Polygonum cilinode Michx. (Tiniaria cilinodis (Michx.) Small.) Fringed black bindweed. In dry sandy open ground. Noticed in particular as abundant on burned over sidehills south of Shingleton.

1 Polygonella articulata (L.) Meisn. Coast jointweed. Dry sandy open ground, especially on jack pine plains. Often abundant.

\section{CHENOPODIACEAE. Goosefoot Family}

Cycloloma atriplicifolium (Spreng.) Coult. Winged pigweed. Sandy open ground. A weed in cities and villages and along railroads.

Chenopodium capitatum (L.) Asch. (Blitum capitatum L.). Strawberry blite. Dryish or damp open ground. Frequent throughout.

Chenopodium glaucum L. Oak-leaved goosefoot. Occasional as a weed in gardens and other cultivated grounds.

Chenopodium hybridum L. Maple-leaved goosefoot. Occasional in open woods, but more frequent in waste places and cultivated grounds as a weed.

Chenopodium album L. Lamb's quarter's. Common pigweed. Common as a weed in streets, waste places and cultivated grounds.

Atriplex patula hastata (L.) Gray. Halberd-leaved orache. Frequent in waste places and eultivated grounds.

Corispermum hyssopifolium I. Bug-seed. Sandy open ground near Manistique. Prof. C. A. Davis, 1905.

Salsola kali tenuifolia G. F. W. Mey. (Salsola pestifer A. Nelson). Russian thistle. Noticed as occasional in eities, villages and cultivated grounds.

\section{AMARANTHACEAE. Amaranth Family}

Amaranthus retroflexus L. Green amaranth. Also often called red root and amaranth pigweed. Noticed only as a weed in waste places and cultivated grounds.

Amaranthus graecizans L. Tumble-weed. In waste place and cultivated grounds as a weed. Apparently not common.

Amaranthus blitoides Wats. Prostrate amaranth. In cultivated and waste grounds as a weed. Oceasional but will probably become abundant.

\section{CARYOPHYLLACEAE. Pink Family}

Spergula arvensis I. Corn spurry. In sandy cultivated fields and waste places as a weer. Cornell.

Arenaria serpyllifolia L. Thyme-leaved sandwort. In dry sandy ground. Frequent as a weed in cities and rillages. 
Stellaria longipes laeta (Richards) Wats. Beach stitchwort. In drifting sand on the sandy beach of.Lake Michigan in the western part of Mackinac County. Abundant. Plant low; flowers small, white.

Stellaria longifolia Muhl. (Alsine longifolia (Muhl.) Britton). Longleaved stitchwort. Damp grassy open places. Frequent.

Stellaria graminea I.: (Alsine graminea (L.) Britton). Lesser stitchwort. Covering sicies and crests of sanct dunes near Lake Michigan shore east of Manistique. Abundant.

Stellaria media (L.) Cyrill. (Alsine meria L.). Common chickweed. A weed in gardens and waste places. Often abundant.

Cerastium vulgatum L. Larger mouse-ear chickweed. A common weed in cities, villages and cultivated grounds.

Agrostemma githago L. Cockle. Corn cockle. Frequent in grain fields and waste places.

Lychnis coronaria (L.) Desr. Mullein pink. Occasional on dryish open ground.

Lychnis alba Mill. White campion. Becoming common in cities and villages and often as a wred in cultivated fields.

Silene antirrhina L. Sleepy catchily. Dryish upen woods or in open sandy ground. Frequent.

Silene noctiflora L. Night-flowering catchfly. Noticed only as a weed in cultivated grounds. Apparently infrequent.

Silene latifo?ia (Mill.) Britten \& Rendle. Bladder campion. In wates places, along railroads and in cultivated grounds. Freçucnt.

Saponaria officinalis L. Soapwort. Bouncing bet. Dry open sandy places, especially in and near cities and villages. Frequent.

Saponaria vaccaria L. (Vaccaria vaccaria (L.) Britton). Cow-herb. In and near cities and villages and along railroads. Infrequent.

\section{PORTULACACEAE. Purslane Family}

Claytonia caroliniana Michx. Carolina spring beauty. In rich shaded ground. Frequent. W. T. S. Cornell.

Portulaca oleracea L. Common purslane. Occasional in dry sandy cultivated grounds as a weed.

\section{NYMPHAEACEAE. Water Lily Family}

Nymphaea advena Ait. In still and stagnant water throughout. Often abundant.

Castalia odorata (Ait.) Woodville \& Wood. Sweet-scented white water lily. Ponds, coves, borders of small lakes, and on margins of slow streams. Noticed in particular in the Tahquamenon River and Muskallonge Lake in Luce County.

Castalia tuberosa (Paine) Greene. Ponds, small lakes and borders of streams. Frequent. 
Brasenia schreberi Gmel. Water shield. Frequent in still water of cores and ponds.

\section{RANUNCULACEAE. Crowfoot Family}

Ranunculus circinatus Sibth. (Batrachium circinatum (Sibth.) Rechb.). Stiff white water crowfoot. Frequent in the shallow water of ditches, ponds and slow streams.

Ranunculus sceleratus L. Cursed crowfoot. Celery-leaved crowfoot. In open wet places, bogs and ditches. Frequent.

Ranunculus abortivus L. Small-flowered crowfoot. Rich damp shaded ground. Frequent.

Ranunculus recurvatus Poir. Hooked crowfoot. Rich woods and open places. Frequent. W. T. S. Cornell.

Ranunculus septentrionalis Poir. Swamp buttercup. Usually in moist shaded ground. Frequent.

Ranunculus pennsylvanicus I.f. Bristly crowfoot. Frequent in open damp ground.

Ranunculus acris L. Tall crowfoot. In damp open or shaded ground. Frequent.

Thalictrum dioicum L. Early meadow rue. Frequent in rich open woods.

Thalictrum dasycarpum Fisch. \& Iall. Tall meadow rue. Frequent in damp open or shaded ground.

Hepatica triloba Chaix. (Hepatica hepatica (L.) Karst.). Roundleaved liver-leaf. Rich open woods. Frequent.

Hepatica acutiloba DC. Sharp-lobed liver-leaf. Usually in beechmaple-birch woods. Frequent.

Anemone cylindrica Gray. Long-fruited anemone. Dry sandy open or partially shaded ground east of Manistique. Apparently infrequent. Anemone virginiana L. Tall anemone. Frequent in open woods.

Anemone canadensis L. Canada anemone. Banks of streams and in open prairie-like ground. Frequent and often abundant.

Anemone quinouefolia L. Wood anemone. Wind-flower. Margins of woods and thickets. Frequent.

Clematis virginiana $\mathrm{L}_{\text {. }}$ Virginia virgin's bower. Banks of small streams. Common.

Caltha palustris .L. Marsh marigold. Open and shaded swampy places. Common.

Coptis trifolia (L.) Salisb. Goldthread. Damp usually shaded places and in tamarack-black spruce swamps. Abundant.

Aquilegia canadensis L. Wild columbine. Dryish open or partially shaded ground. Frequent.

Actaea rubra (Ait.) Willd. IRed baneberry. In rich woods and thickets. Frequent. 
A ctaea rubra forma neglecta (Gillman) Robinson. White-fruited red baneberry. Frequent with the preceding. Fruit white, pedicels capillary.

Actaea alba (L.) Mill. White baneberry. Frequent in rich woods. pedicels not capillary, but thickened in fruit. Berries white.

\section{BERBERIDACEAE. Barberry Family}

Caulophyllum thalictroides (L.) Michx. Blue cohosh. In hardwoods near Indian Lake and at Floodwood. Apparently infrequent.

\section{PAPAVERACEAE. Poppy Family}

Sanguinaria canadensis L. Bloodroot. In open rich woods. Frequent.

\section{FUMARIACEAE. Fumitory Family}

Dicentra cucullaria (L.) Bernh. (Bicuculla cucullaria (L.) Millsp.). Dutchman's breeches. Rich woods. Frequent. Cornell.

Dicentra canadensis (Goldic) Walp. (Bicuculla canadensis (Goldie) Millsp.). Squirrel corn. Rich woods. Frequent.

Corydalis sempervirens (L.) Pers. (Capnoites sempervirens (L.) Bork.) Pale corydalis. Common and often abundant on burned over dry ground.

\section{CRUCIFERAE. Mustard Family}

Alyssum alyssoides L. Yellow alyssum. In dry open ground as a weed about cities and villages. Apparently not common.

Thlaspi arvense L. Field penny-cress. Occasional as a weed about cities and villages. Apparently infrequent.

Lepidium virginicum L. Wild peppergrass. A weed in waste places, gardens and on roadsides. Frequent. Tuch resembling the following.

Lepidium apetalum Willd. Apetalous peppergrass. In cities, villages, and cultivated grounds. Frequent. Described under L. densiflorum Schrad. in Britton and Brown's "Illustrated Flora", Second Edition, Vol. II, page 166 .

Capsellu bursa-pastoris (L.) Medic. (Bursa bursa-pastoris (I.) Britton). Shepherd's purse. A common weed in gardens, fields and waste places.

Cametina sativa (L.) Crantz. Gold-of-pleasure. False flax. Occasional in cities, villages and along railroads.

Cakile edentula (Bigel.) Hook. American sea rocket. Sandy beach of Lake Michigan. Frequent.

Brassica arvensis (L.) Ktze. (Sinapis arvensis L.). Common mustard. Charlock. A weed about cities and villages, and in cultivated grounds. Often too abundant. 
Brassica nigra (L.) Koch. Black mustard. Occasional as a weed about cities and villages.

Sisymbrium officinale leiocarpum DC. Smooth-podded hedge-mustard. A weed about dwellings and in waste places. Frequent. The species with pubescent pods may yet be noticed.

Sisymbrium altissimum L. (Norta altissima (L.) Britton). Tumble mustard. In cities and villages as a weed. Often plentiful.

Erysimum cheiranthoides L. (Cheirinia cheiranthoides (L.) Link.). Worm-seed mustard. Mostly as a weed in cities and villages. Occasional in fields.

Radicula nasturtium-aquaticum (L.) Britton \& Rendle. True watercress. In brooks and ditches. Frequent.

Radicula palustris (L.) Moench. Marsh cress. Wet open places and often in shallow water. Frequent throughout.

Radicula armoracia (L.) Robinson. (Armoracia armoracia (L.) Britton). Horseradish. Escaping into moist places of cities and villages and persisting. Frequent.

Dentaria diphylla Michx. Crinkle-root. In hardwoods. Apparently infrequent.

Cardamine pennsylvanica Muhl. Pennsylvania bitter-cress. In very wet and open or shaded swampy places. Often abundant.

Arabis lyrata L. Lyre-leaved rock-cress. On and near the sandy beaches of Lake Michigan and Lake Superior. . Often plentiful.

Arabis glabra (L.) Bernh. Tower mustard. Frequent in dry open places or in open woods.

SARRACENIACEAE. Pitcher-plant Family

Sarracenia purpurea L. Pitcher-plant. Common in tamarack-black spruce swamps.

DROSERACEAE. Sundew Family

Drosera rotundifolia L. Round-leaved sundew. Boggy open ground. Frequent.

CRASSULACEAE. Orpine Family

Sedum acre I. Mossy stónecrop. Dry open sandy ground in and near cities and villages. Sometimes covering the ground and abundant.

Sedum purpureum Tausch. (Sedum triphyllum (Haw.) S. F. Gray). Live-forever. Escaping from cultivation and persisting in various places. Frequent. 


\section{SAXIFRAGACEAE. Saxifrage Family}

Saxifraga pennsyluanica L. (Micranthes pennsylvanica (L.) Haw.). Swamp saxifrage. On margins and in open spots of tamarack-black spruce swamps. Plentiful.

Mitella diphylla L. Two-leaved bishop's-cap. Damp rich woods and thickets. Frequent.

Mitella nuda L. Naked bishop's-cap. Damp rich shaded ground. Common.

Chrysosplenium americanum Schwcin. Golden saxifrage. Cool wet open or shaded places. Often abundant.

Parnassia parrifora DC. Small-flowered grass-of-parnassus. In springy and wet meadow-like places. Abundant in spots. Noticed in particular near Munising, Alger County.

Parnassia caroliniana Michx. Carolina grass-of-parnassus. Common in wet, swampy open or shaded places.

Rithes oxyacanthoides calcicola Fernald. (Grossularia hirtella (Michx.) Spach.). Low wild gooseberry. Damp open or partially shaded ground. Pientiful.

Ribes floridum L'Hêr. (R. americanum Mill.). Wild black cürant. Damp open or shaded ground. Plentiful.

Ribes lacustre (Pers.) Poir. Swamp black currant. Cool damp shaded ground. Frequent.

Ribes prostratum L'Her. (R. glandulosum Grauer.). Fetid currant. Skunk currant. Damp shaded ground, sometimes in the open. Frequent.

Ribes triste Pall. Swamp red currant. American red currant. Damp hardwoods. Frequent.

\section{ROSACEAE. Rose Family}

Physocarpus opulifolius (I.) Maxim. (Opulaster opulifolius (L.) Kuntze). Ninebark. Common along streams. Noticed as plentiful in crevices of limestone rock on Lake Michigan shore at Seul Choix.

Spiraea salicifolia L. Common meadow-sweet. In low mostly open ground. Common. Apparently S. alba DuRoi or S. latifolia (Ait.) Borkh. of some authors.

Spiraea tomentosa L. Hardhack. Steeple bush. Usually in low damp open ground. Common about Manistique. Cornell.

Pyrus malus L. (Malus malus (L.) Britton). Common apple. Noticed as frequent throughout in a wild state.

Pyrus arbuitifolia atropurpurea (Britton) Robinson. (Aronia atrepurpurea Britton). Purple-fruited choke-berry. Frequent in low swampy ground and often in shade. Ripe fruit claret colored to purplish black.

Pyrus melanocarpa (Michx.) Willd. (Aronia melanocarpa (Michx.) 
Britton). Black choke-berry. Damp open places especially on margins of tamarack-black spruce swamps. Common especially about Manistique. Ripe fruit black.

Pyrus americana (Marsh) DC. (Sorbus americana Marsh). American mountain ash. Common on margins of woods. Often large, 50 feet high and more.

Amelanchier laevis Wiegand. Smooth-leaved juneherry. Borders of, and in, rich woods near Lake Michigan shore. Plentiful. Noticed in particular in the western part of Mackinac County, where many trees were 18 inches in diameter 4 fect from the ground and 50 feet high. see Rhodora, Vol. 14, page 158 .

Crataegus punctata Jacq. Large-fruited thorn. Usually in damp open or partially shaded ground. Frequent throughout.

Crataegus douglasii Lindil. Douglas' thorn. (C. broclwayac Sarg.). Very probably to be found throughout in dry damp, open or sharled ground. Noticed in particular on Grand Island in Alger County.

Fragaria virginiana Duchesne. Common strawberry. Common in both damp or dry open ground throughout.

Fragaria vesca americana Porter. (F. americana (Porter) Britton). American wood strawberry. In damp hardwoods and tamarack-black spruce swamps. Frequent.

Potentilla monspeliensis I. Rough einquefoil. In open dry sandy ground throughout. Frequent as a roadside and field weed.

Potentilla argentea L. Silvery cinquefoil. Frequent in dry open ground.

Potentilla palustris (L.) Scop. (Comarum palustre L.). Marsh cinquefoil. Very wet and swampy open places. Common.

Potentilla fruticosa L. (Dasiphora fruticosa (L.) Rydl).). Shrubby cinquefoil. Wet or dry open ground. Often abundant.

Potentilla tridentata Ait. (Sibbaldiopsis tridentata (Soland.) Rydb.). Three-toothed cinquefoil. Dryish sandy or gravelly open or partially shaded ground throughout. Plentiful in spots.

Potentilla anserina L. (Argentina anserina (L.) Rydb.). Silver-weed. Usually in dry or damp open ground near Lake Michigan or Lake Superior shore. Often abundant.

Potentilla canadensis L. Common cinquefoil. Frequent in dry open ground.

Geum canadense Jacq. White avens. Frequent in and near hardwoods.

Geum strictum Ait. Yellow avens. Moist open ground. Plentiful.

Geum rivale L. Purple avens. Damp open or partially shaded ground. Frequent.

Rubus illaeus aculeatissimus (C. A. Mey) Regel \& Tiling. (K. strigosus 
Michx. of some authors). Wild red raspberry. Dry open or partially shaded ground. Abundant.

Rubus parviflorus Nutt. Salmon-berry. Usually in open woods. Often plentiful.

Rubus triflorus Richards. Dwarf raspberry. Damp open or shaded ground. Common.

Rubus allegheniensis Porter. Tall blackberry. Open places and burned over ground. Common.

Rubus canadensis I. Millspaugh's blackberry. Mostly borders of hardwoods and along streams. Plentiful. This is not the dewberry formerly having this scientific name, but an upright shrub.

Rubus nigricans Rydb. Bristly blackberry. In marshy and swampy ground. Often very abundant. A creeping or ascending shrub, resembling the dewberry, but with small insignificant fruit.

Rubus hispidus I. Running swarnp blackberry. Tamarack-black spruce swamps. Often abundant.

Rubus villosus Ait. (R. procumbens Muhl.). Dewberry. Dry open ground. Often plentiful. Fruit large and palatable. Formerly having the scientific name of Rubus canadensis $\mathrm{L}$.

Agrimonia gryposepala Wallr. Tall hairy agrimony. In hardwoods and thickets. Frequent.

Agrimonia striata Michx. Britton's agrimony. Damp open woods and along streams. Apparently infrequent. Noticed in particular near the upper falls of the Tahquamenon River in Luce County.

Rosa acicularis Lindl. Prickly rose. Dryish open or partially shaded ground. Frequent.

Rosa blanda Ait. Meadow rose. Dryish open ground. Often abundant on sandy beaches and sand dunes acting as an efficient sand binder. Sometimes afflicted by the gall-fly, Rhodistes bicolor.

Rosa rubiginosa L. Sweetbrier. Occasional on roadsides as an escape. Prunus serotina Ehrh. (Padus virginiana (L.) Mill.). Wild black cherry. Occasional throughout. Apparently more frequent near Munising in Alger County.

Prunus virginiana L. (Padus nana (DuRoi) Roemer.). Choke cherry. In dry or damp ground. Common throughout.

Prunus pennsylvanica L.f. Wild red cherry. Open woods and clearings. Very abundant on burned over ground.

Prunus cuneata Raf. Appalachian cherry. Dryish sandy open ground. Often plentiful.

Prunus pumila L. Sand cherry. Plentiful on the sandy beaches of Lake Michigan and Lake Superior. Also often covering sand dunes. An efficient sand binder.

Prunus nigra Ait. Canada plum. Borders of woods and banks of 
streams. Frequent. Noticed in particular near the Lake Michigan shore in the western part of Mackinac County.

\section{LEGUMinosaE. Pulse Family}

Trifolium pratense L. Red clover. Roadsides, waste places and clearing. Frequent and thrifty. Our cultivated clover.

Trifolium repens L. White clover. Noticed as frequent throughout in cities, villages, pastures and on roadsides.

Trifolium hybridum L. Alsike clover. Roadsides, clearings and in waste places. Frequent throughout and thrifty.

Melilotus officinalis (L.) Lam. Yellow sweet clover. Waste places about cities and villages. Infrequent. Cornell.

Melilotus alba Desr. White sweet clover. Waste places and roaclsides. Occasional. Cornell.

Medicago sativa L. Alfalfa. Occasional in cities and villages. Cornell.

Medicago luputina I. Black medic. In cities and villages and about farm buildings. Frequent.

Vicia angustifolia (L.) Reichard. Smaller common vetch. Occasional about cities and villages and along railroads.

Ticia americana Muhl. American vetch. Moist or dryish open ground. Occasional. Noticed in particular near Rexton in the western part of Mackinac County.

Lathyrus maritimus (L.) Bigel. Beach pea. Sandy beaches of Lake Michigan and Lake Superior. Often plentiful. An efficient sand binder.

Lathyrus palustris linearifolius Ser. Winged marsh vetchling. Frequent in damp open places and margins of woods throughout.

Lathyrus ochroleucus Hook. Pale vetchling. Iryish shaded ground near Seul Choix. Apparently infrequent.

\section{LINACEAE. Flax Family}

Linum usitatissimum L. Common flax. Streets and depot grounds of cities and villages. Frequent.

\section{OXALIDACEAE. Wood Sorrel Family}

Oxalis acetosella L. Common wood sorrel. White wood sorrel. In hardwoods and low wet shaded ground. Often very abundant.

Oxalis stricta L. (Xanthoxalis stricta (I.) Small). Upright yellow wood sorrel. In cities and villages and along railroads. Apparently infrequent.

Oxalis corniculata L. (Xanthoxalis corniculata (L.) Small). Yellow 
procumbent sorrel. As a weed about cities and villages, but apparently rare.

GERANIACEAE. Geranium Family

Geranium maculatum L. Wild crane's-bill. In hardwoods and along old roads. Seldom plentiful.

Geranium robertianum I. (Robertiella robertiana (L.) Hanks.). Herb robert. In damp woods and on sandy beaches of Lake Michigan. Not noticed as anywhere abundant.

Geranium bicknellii Britton. Bicknell's crane-bill. Clearings, open places, and burned over areas. Jlentiful. W. T. S. Cornell.

POLYGALACEAE. Milkwort Family

Folygala paucifotia Willd. Fringed polygala. Dry shaded ground. Often plentiful. Cornell.

\section{EUPHORBIACEAE. Spurge Family}

Euphorbia glyptosperma Engelm. (Chamaesyce glyptosperma (Englm.) Small). Ridge-seeded spurge. Noticed as plentiful along railroads.

Euphorbia maculata L. (Chamaesyce maculata (I.) Small). Milk purslane. In cities, villages and on roadsides. Frequent.

CALLITRICHACEAE. Water Starwort Family

Callitriche palustris L. Vernal water-starwort. In mud or water of ponds, small lakes and sluggish streams. Often plentiful.

Callitriche autumnalis I. Autumnal water-starwort. Frequent in shallow still water of ponds, small lakes and streams. Noticed in particular in the Tahquamenon River in Luce County.

\section{EMPETRACEAE. Crowberry Family}

Empetrum nigrum I. Black crowberry. Noticed by G. H. Hicks near the Pictured Rocks and by Prof. C. A. Davis near Grand Marais in Alger County.

\section{ANACARDIACEAE. Cashew Family}

Rhus typhina L. (R. hirta (L.) Sudw.). Staghorn sumach. Usually not far from Lake Michigan shore in dry open or particularly shaded ground. Abundant in spots.

Rhus glabra L. Smooth sumach. Dryish open or partially shaded ground. Frequent throughout.

Rhus toxicodendron L. (Toxicordendron radicans (L.) Kuntze). 
Poison ivy. In woods, dry sandy ground and on sandy beaches. Often plentiful. This shrub often becomes a vine and tree climber, when some authors give it the name of Rhus toxicodendron radicans (L.) Torr., climbing poison ivy.

\section{AQUIFOLIACEAE. Holly Family}

Ilex verticillata (L.) Gray. Black alder. Winterberry. In low open or partially shaded ground. Common.

Nemopanthes mucronata (L.) Trel. Mountain holly. In damp woods and swampy ground throughout. Often abundant. Known in Lice County as "buck-bush" or "buck-brush" from the fact that deer brouse it.

CELASTRACEAE. Staff Tree Family

Celastrus scandens L. Known as "bittersweet" in Michigan and western Ontario. Usually a vine climbing trees. Noticed west of Manistique and along the Manistique River at Cermfask. Apparently infrequent. Cornell.

ACERACEAE. Maple Family

Acer pennsylvanicum L. Striped maple. On borders of, and in, rich woods throughout. Plentiful.

Acer spicatum Lam. Mountain maple. On borders of, and in, rich woods. Often abundant. A shrub or small tree. It is said deer brouse the tree heavily and strip off its bark and that elk formerly did the same.

Acer saccharum Marsh. Sugar maple. One of the three principal and dominant trees of the hardwoods. Abundant throughout.

Acer saccharinum L. Silver maple. Planted occasionally; but apparently not spreading.

Acer rubrum I. Red maple. Rich woods with other trees, where it is a fair sized tree, also common on dry sandy ground and even covering sand dunes, when it is small and scraggy. Reported that deer greedily brouse and peel the bark from the tree.

Acer negundo L. Box elder. Occasionally planted, but apparently not spreading.

BALSAMINACEAE. Touch-me-not Family

Impatiens biflora Walt. Spotted touch-me-not. Damp open or shaded ground. Abundant throughout.

RHAMNACEAE. Buckthorn Family

Rhamnus alnifolia L'Her. Alder-leaved buckthorn. Wet open or shaded ground throughout. 


\section{VITACEAE. Vine Family}

Psedera vitacea (Kneer) Greene. Grape-like virginia creeper. In rich woods and on banks of streams. A vine and tree climber. Frequent throughout.

Vitis vulpina L. Riverside grape. Plentiful on Round Island in Mackinac County. Not noticed elsewhere yet (1915) in the Upper Peninsula.

\section{TILIACEAE. Linden Family}

Tilia americana L. Occasional in hardwoods and reaching the south shore of Lake Superior. Trees often very large.

MALVACEAE. Mallow Family

Abutilon theophrasti Medic. (A. abutilon (L.) Rusby). Velvet-leaf. Occasional as a weed in gardens, waste places and fields.

Malva rotundifolia L. Common mallow. Cheeses. Plentiful as a weed in waste places and cultivated grounds.

Malva moschata L. Musk mallow. Noticed as a weed in fields and on roadsides west of Manistique.

\section{HYPERICACEAE. St. John's-wort Family}

IIypericum ascyron L. Great St. John's-wort. Damp open ground and on banks of small streams west of Manistique. Apparently infrequent.

Hypericum kalmianum I. Kalm's St. John's-wort. Usually in dry, sandy, open ground on and near the sandy beaches of Lake Michigan and Lake Superior. Often plentiful.

Hypericum ellipticum Hook. Paie St. John's-wort. Wet places, along streams and on wet sandy shores. Frequent.

Hypericum boreale (Britton) Bicknell. Northern St. John's-wort. Very wet boggy places and margins of ponds. Frequent.

Hypericum virginicum I. (Triadenum virginicum (L.) Raf.). Marsh St. John's-wort. Open marshy and swampy places. Frequent.

\section{CISTACEAE. Rockrose Family}

Helianthemum canadense (L?) Michx. (Cracanthemum canadense (L.) Britton). Long-branched frostweed. On sand dunes west of Manistique. Plentiful. Prof. C. A. Davis, 1905.

Hudsonia tomentosa Nutt. False heather. Sandy beaches of Lake Michigan and Lake Superior. Often abundant. 
VIOLACEAE. Violet Family

Viola cucullata Ait. Marsh blue violet. Very wet open or partially shaded places. Common.

Viola nephrophylla Greene. Northern bog violet. Wet open or partially shaded ground throughout. Frequent.

Viola affinis LeConte. LeConte's violet. Moist meadow-like ground and in damp partially shaded places. Plentiful. W. T. S. Cornell.

Viola selkirkii Pursh. Great spurred violet. In hardwoods near Floodwood. Apparently infrequent. Very probal,ly overlooked.

Viola lanceolata L. Iance-leaved violet. Moist or boggy and mostly open places. Abundant and much larger than in the Lower Peninsula.

Viola pullens (Banks) Brainerd. Northern white violet. Wet springy open or partially shaded places. Frequent.

Viola blanda Willd. Sweet white violet. Pich moist open or partially shaded ground. Frequent.

Viola incognita Brainerd. Large-leaved white violet. Margins of, and open places in, hardwoods. Common.

Viola renifolia A. Gray. Kidney-leaved violet. Damp places in hardwoods. Common.

Viola scabriuscula Schwein. (V. eriocarpa Schwein.). Smoothish yellow violet. Frequent in hardwoods.

Viola cànadensis I. Canada violet. In hardwoods and often abmdant.

Viola conspersa Reichenb. American dog violet. Low damp open or shaded ground. Often abundant.

\section{THYMELAEACEAE. Mezereum Family}

Dirca palustris L. Leatherwood. Moosewood. Damp rich open woods. Frequent in Schoolcraft County. Cornell. Also in ilger County. Thomas B. Wyman. Not noticed by the writer.

ELAEAGNACEAE. Oleaster Family

Shepherdia canarlensis (L.) Nutt. (Lepargyraea canadensis (L.) Greene.). Canadian buffalo berry. Dry open or partially shaded ground. Frequent.

\section{ONAGRACEAE. Evening Primrose Family}

Epilobium angustifolium L. (Chamaenerion angustifolium (L.) S('op.) Great willow-herb. Fireweed. Dryish open or partially shaded ground. Abundant on burned over land.

Epilobium densum Raf. (E. lineare Muhl.). Linear-leaved willowherb. Low open ground and often abundant. 
Epitobium adenocaulon Haussk. Northern willow-herb. Rich damp open or partially shaded ground, throughout. Plentiful.

Oenothera biennis L. Common evening primrose. Dryish open ground and on sandy shores. Frequent.

Oenothera pumila L. (Kneiffia pumila (L.) Spach.). Small sun-drops. Dry open ground near Manistique. Apparently infrequent. Prof. C. A. Davis, 1905.

Circaea lutetiana L. Enchanter's nightshade. Open hardwoods. Frequent.

Circaea alpina L. Smaller enchanter's nightshade. Damp places in hardwoods. Frequent and often plentiful.

\section{HALORAGIDACEAE. Water Milfoil Family}

Myriophyllum spicatum L. Spiked water milfoil. In stagnant water or on margins of slow streams. Apparently infrequent.

Hippuris vulgaris L. Mare's-tail. Ponds and slow streams. Frequent. Noticed in particular near Manistique in mud and shallow water of small streams.

ARALIACEAE. Ginseng Family

Aralia racemosa L. American spikenard. In rich woods and thickets. Frequent.

Aralia hispida Vent. Bristly sarsaparilla. In sandy open or partially shaded gı ound. Abundant on burned over areas.

Aratia nudicaulis L. Wild sarsaparilla. In hardwoocis and generally in rich shaded ground. Often very abundant.

Panax quinquefolium L. Ginseng. Reported but not seen growing wild. At Rexton in the western pait of Mackinac County, this and golden seal are successfully cultivated by Christian Hansen.

\section{UMBELLIFERAE. Parsley Family}

Sanicula marilandica L. Black snakeroot. Rich shaded ground. Plentiful.

Osmorhiza claytoni (Michx.) Clarke. (Tashingtonia claytoni (Michx.) Britton). Woolly sweet-cicely. Common in hardwoods.

Osmorhiza longistylis (Torr.) DC. (W'ashingtonia longistylis (Torr.) Britton). Smoother sweet-cicely. In hardwoods throughout. Common.

Osmorhiza iongistylis villicaulis Fernald. Hairy-stemmed sweetcicely. Rich hardwoods near Lake Michigan shore. Apparently infrequent.

Osmorhiza divaricata Nutt. Western sweet-cicely. Occasional in hardwoods. 
Conium maculatum L. Poison hemlock. Frequent in waste places about cities and villages.

Cicuta bulbifera L. Bulb-bearing; water hemlock. Marshy and swampy open ground throughout. Often abundant. Root supposed to be very poisonous.

Carum carvi L. Caraway. Frequent as a weed about cities and villages.

Sium cicutaefolium Schrank. Hemlock water-parsnip. Wet swampy places and often in shallow water. Frequent.

Pastinaca sativa L. Wild parsnip. Frequent as an escape from cultivation to roadsides and waste places in cities and villages. Root not believed to be poisonous. The frequent fatal poisoning reported in the Lower Peninsula and credited to wild parsnip is very probably not this plant, but the tuberous roots of Cicuta maculata L., which have an aromatic odor, a pleasant sweetish taste like the roots of sweet cicely and are very poisonous, no remedy being yet known. This latter is usually known as "water hemlock," "beaver poison" and other common names, and has not yet (1915) been noticed by the writer in the Upper Peninsula.

Heracleum lanatum Michx. Cow-parsnip. Damp open or partially shaded ground. Frequent.

Angelica atropurpurea L. Purple-stemmed angelica. Damp open ground near Seul Choix, where it was plentiful. Not noticed elsewhere.

Daucus carota L. Wild carrot. Waste places and cultivated grounds. Apparently not yet abundant.

\section{CORNACEAE. Dogwood Family}

Cornus canadensis L. (Chamaepericlymenum canadense (I.) Asch. \& Graebn.). Iow cornel. Dwarf cornel. Dryish or damp sharled ground especially in hardwoods. Often very abundant, fairly carpeting the ground.

Cornus circinata L'Her. (C. rugosa Lam.). Round-leaved cornel. Sandy open or partially shaded ground. Plentiful.

Cornus amomum Mill. Silky cornel. Sand dumes near Lake Michigan west of Manistique. Plentiful.

Cornus stolonifera Michx. Red-osier dogwood. Wet ground throughout. Frequent.

Cornus alternifolia l.f. Alternate-leaved cornel. Frequent on margins of hardwoods and along banks of streams.

ERICACEAE. Heath Family

Chimaphila umbellata (L.) Nutt. Prince's pine. Pipsissewa. Dry shaded ground, usually in coniferous woods. Plentiful. 
Moneses uniflora (L.) Gray. One-flowered pyrola. Damp rich woods near Floodwood. Apparently infrequent. Perhaps overlooked.

Pyrola secunda L. One-sided wintergreen. Plentiful in rich woods throughout.

Pyrola elliptica Nutt. Shin-leaf. Dryish woods. Apparently infrequent. Cornell.

Pyrola asarifolia Michx. Liver-leaf wintergreen. Damp open woods and swampy places. Plentiful.

Pyrola asarifolia incarnata (Fisch.) Fernald. (P. uliginosa Torr.). Bog wintergreen. In damp wookls and boggy places. Frequent.

Monotropa uniflora L. Indian pipe. Rich dryish or damp open woods. Often plentiful. Cornell.

Pterospera andromedea Nutt. Pine drops. Among pines. Apparently rare. Cornell.

Ledum groenlandicum Oeder. Labrador tea. Bogs throughout. One of the dominant bog shrubs.

Kalmia polifolia Wang. Pale laurel. Open bogs. Often plentiful. Cornell.

Andromeda glaucophylla Link. Bog rosemary. In open bogs and one of the dominant bog shrubs.

Chamacdaphne calyculata (L.) Moench. Leather-leaf. Common and often abundant in open bogs throughout.

Epigaea repens L. Trailing arbutus. Mayflower. Open or shaded dry sandy ground. Common throughout.

Gaultheria procumbens L. Wintergreen. Dry open or shaded sandy ground or even in sphagnum of tamarack-black spruce swamps. Very abundant throughout.

Arctostaphylos uva-ursi (I.) Spreng. (L'va-ursi uva-ursi (L.) Britton). Red bearberry. Open or partially shaded dry sandy ground, especially near shores and even on sand dunes, where it acts as an efficient sand binder.

Chiogenes hispidnla (L.) T. \& G. Creeping snowberry. Bogs especially on borders of, and in, tamarack-black spruce swamps. Often abundant.

Gaylussacia baccata (Wang.) C. Koch. Black huckleberry. Usually in dry open or shaded ground, but sometimes in swamps. Corrmon.

Vaccinium pennsylvanicum Lam. ( $V$. angustifolium Ait.). Low sweet blueberry. Usually in dry open sandy ground and very abundant throughout.

Viccinium pennsylvanicum niarum Wood. (V. nigrum (Wood) Britton). Low black blueberry. Frequent, growing in patches with the preceding. Berries very black, otherwise much like the preceding in general appearance.

Vaccinium canadense Kalm. Sour-top. Canada blueberry. Mostly cn dry open sandy ground, but occasionally found in bogs and swamps. 
The fruit of this and the two preceding is gathered and sold as "blueberries."

Vaccinium membranaceum Dougl. Thin-leaved bilberry. Usually in rich shaded ground, sometimes in damp shaded sand. Frequent. Locally called rabbit berry. Fruit large, black, rather tart, but clelicious.

Vaccinium ovalifolium Sm. Oval-leaved bilberry. Usually in rich shaded ground, often growing with the preceding. Frequent. Berries blue, large but smaller than the preceding, slightly tart but delicious. Often locally called "myrtilloid berry" or "myrtilloid huckleberry."

Vaccinium oxycoccos L. (Oxycoccus oxycoccus (L.) MacMI.). Small cranberry. In open or shaded swamps and often growing in spagnum. Plentiful.

Vaccinium macrocarpon Ait. (Oxycoccus macrocarpus (Ait.) Pursh.). American cranberry. Abundant in what are called cranberry marshes.

\section{PRIMULACEAE. Primrose Family}

Primula mistassinica Michx. Dwarf Canadian primrose. Damp open ground and often abundant.

Lysimachia terrestris (1..) BSP. Bulb-bearing loosestrife. Low wet and usuaily open ground throughout. Common.

Lysimachia thyrsiflora L. (Naumburgia thyrsiflora (L.) Duby.). Tufted loosestrife. In wet open ground and shallo: water. Common.

Trientalis americana (Pers.) Pursh. Starflower. Damp rich woods and thickets. Common.

\section{OLEACEAE. Olive Family}

Fraxinus pennsylvanica Marsh. Red ash. Occasional throughout. One large tree in the city of Manistique. Abundant along the Tahquamenon River in Luce County.

Fraxinus pennsylvanica lanceolata (Borkh.) Sarg. (F. viridis Michx.). Green ash. In rich ground and along streams and said to be frequent in Alger County. Thomas B. Wyman.

Fraxinus nigra Marsh. Black ash. Swamps and low banks of streams throughout. Common.

\section{GENTIANACEAE. Gentian Family}

Gentiana procera Holm. Smaller fringed gentian. Moist open ground mostly near shores in this region. Usually small and abundant.

Gentiana andrewsii Griseb. (Dasystephana andrewsii (Griseb.) Small). Closed gentian. Moist open or partially shaded ground. Apparently infrequent. 
Gentiana linearis latifolia Gray. (Dasystephana grayi (Kusnezow) Britton). Gray's gentian. Damp sandy open or partially shaded ground throughout. Often plentiful. This has been noticed mostly in damp sandy ground near the shores of the three Great Lakes.

Halenia deflexa (Sm.) Griseb. Spurred gentian. In hardwoods and often abundant.

Menyanthes trifoliata L. Buckbean. Opeu bogs and often in shallow water. Plentiful.

\section{APOCYNACEAE. Dogbane Family}

A pocynum androsaemifolium L. Spreading dogbane. Dryish ground on borders of woods. Plentiful.

Apocynum cannabinum hypericifolium (Ait.) Gray. (A. sibiricum Jacq.). Clasping-leaved dogbane. Damp or marshy mostly open ground and on banks of streams. Plentiful.

\section{ASCLEPIADACEAE. Milkweed Family}

Asclepias incarnata I. Swamp milkweed. Swampy and usually open ground throughout. Abundant in marshy ground on and near the low banks of the Tahquamenon River in Luce County.

Asclepias syriaca L. Common milkweed. Observed by W. T. S. Cornell near Manistique. Apparently rare.

\section{CONVOlvUlaceaE. Convolvulus Family}

Convolvulus spithamaeus L. Low bindweed. Open or partially shaded dry sandy ground. Plentiful throughout.

Convolvulus sepium I. Hedge bindweed. Moist open ground and along streams. Apparently infrequent.

Convolvulus arvensis L. Small bindweed. Field bindweed. In waste places and along railroads. A weed that will become more and more frequent.

\section{BORAGINACEAE. Borage Family}

Cynoglossum officinale L. Common hound's-tongue. Frequent in waste places and on roadsides.

Lappula echinata Gilibert. (Lappula lappula (L.) Karst.). European stickseed. Waste places, roadsides and in cultivated grounds. Frequent.

Lithospermum officincle L. Common gromwell. Frequent in cities, villages and on roadsides.

Lithospermum gmelini (Michx.) Hitchc. (L. carolinense (Walt.) MacM.). Hairy puccoon. In open sandy ground and on sandy beaches east of Manistique. Plentiful. 
Echium vulgare I. Blue-weed. Occasional as a weed in cities and villages. Cornell.

VERBENACEAE. Vervain Family

Verbena hastata I. Blue vervain. Damp open ground. Apparently infrequent.

\section{LABIATAE. Mint Family}

Scutellaria lateriflora L. Mad-dog skullcap. Damp shaded ground. Frequent.

Scutellaria galericulata L. Hooded willow-herb. Wet open ground. Frequent.

Marrubium vulgare I. Common horehound. Waste places in rities and villages and about farm dwellings. Frequent.

Nepeta cataria L. Catnip. As a weed about dwellings, in gardens and fields. F'requent.

Nepeta hederacea (L.) Trevisan. (Glechoma hederacea I..). Ground ivy. Waste places of cities and villages and often a vicious lawn weed. Frequent and well distributed.

Prunella vulgaris L. Self-heal. Cities; villages, roadsides and open woods. Apparently infrequent.

Galeopsis tetrahit I. Common hemp-nettle. Fields, roadsides and waste places. A frequent weed.

Leonurus cardiaca L. Motherwort. A frequent weed about dwellings, in gardens and waste places.

Stachys palustris L. Hedge nettle. Wound-wort. Wet open ground. Often abundant.

Monarda fistulosa L. Wild bergamot. Damp woods near Seul Choix, where it is plentiful.

Monarda mollis L. Pale wild bergamot. Frequent in dry open ground.

Satureja glabra (Nutt.) Fernald. (Clinopodium glabrum Nutt.). Low calamint. Noticed in damp sandy open ground near Lake Michigan beach. A small sweet-smelling plant with small pretty pink flower: and often mistaken for a species of pennyroyal.

Satureja vulgaris (L.) Fritsch. (Clinopodium vulgare L.). Field basil. Dry open or partially shaded ground. Frequent.

Lycopus uniflorus Michx. Northern bugleweed. Frequent throughout in low and usually shaded ground.

Lycopus americanus Muhl. Cut-leaved water horehound. Damp open or shaded ground. Common.

Mentha arvensis canadensis (L.) Briquet. (M. canadensis L.). American wild mint. Damp rich open or shaded ground throughout. Common. 
Mentha arvensis lanata Piper. Woolly wild mint. Roadside near Germfask. Apparently infrequent.

\section{SOLANACEAE. Nightshade Family}

Solanum dulcamara I. Climbing nightshade. Bittersweet. Noticed as frequent throughout in cities and villages.

Solanum nigrum I. Common nightshade. Black nightshade. Frequent as a weed in gardens and other cultivated grounds.

Physalis grandiflora Hook. (Leucophysalis grandiflora (Hook.) Rydb.). Large white ground-cherry. Sandy shores and recent clearings. Often plentiful. Abundant about Naubinway in the westcrn part of Mackinac County.

Lycium halimifolium Mill. Matrimony vine. Escaping into dry open ground and persisting near Manistique.

\section{SCROPHULARIACEAE. Figwort Family}

Verbascum thapsus L. Common mullein. Roadsides, pastures and cultivated grounds. Common as a weed.

Linaria vulgaris Hill. (Linaria linaria (L.) Karst.). Butter-andeggs. Cities, villages, roadsides and cultivated grounds. Plentiful as a weed.

Scrophularia leporella Bickiell. Rich open or partially sharted ground throughout. Often plentiful.

Chelone glabra L. Snake-head. Turtle-head. Plentiful in wet open or partially shaded places.

Mimulus glabratus jamesii (T.\& \&.) Gray. (M.geyeri Torr.). Geyer's yellow monkey-flower. In shallow water or wet springy places. Frequent.

Veronica americana Schwein. American brooklime. In brooks, ditches and wet places. Common.

Veronica scutellata L. Marsh speedwell. In wet open or shaded swampy places. Apparently infrequent.

Veronica officinalis L. Common speedwell. Dryish open or shaded ground. Apparently infrequent.

Veronica serpyllifolia L. Thyme-leaved speedwell. Damp grassy places in and near cities and villages. Frequent.

Veronica peregrina L. Purslane speedwell. Usually in rich cultivated grounds. Often abundant as a garden weed.

Gerardia paupercula (Gray) Britton. (Agalinis paupercula (A. Gray) Britton). Small-flowered gerardia. Dry sterile ground, bogs, and sandy beaches. Often abundant.

Castilleja coccinca (L.) Spreng. Scarlet painted-cup. Usually in low damp, sandy, open ground. Often abundant. 
Melampyrum lineare Lam. Narrow-leaved cow-wheat. Usually in dryish shaded ground. Often abundant in open hardwoods.

\section{LENTIBULARIACEAE. Bladderwort Family}

Utricularia vulgaris americana Gray. (U. macrorhiza LeConte). Greater bladderwort. Frequent in ponds and slow streams throughout.

Utricularia intermedia Hayne. Flat-leaved bladderwort. In very wet places, shallow water, pools and slow shallow streams. Often abundant.

Utricularia cornuta Michx. (Stomoisia cornuta (Michx.) Raf.). Horned bladderwort. Peat bogs and wet sandy shores. Often abundant.

Pinguicula vulgaris L. Common butterwort. Wet calcareous places and often among rocks near the shores of the upper Great Lakes. Plentiful.

\section{OROBANCHACEAE. Broom-rape Family}

Epifagus virginiana (L.) Bart. (Ieptamnium virginianum (L.) Raf.). Beech-drops. Common and often abundant under beeches.

PLANTAGINACEAE. Plantain Family

Plantago major L. Common plantain. Cities, villages and near all dwellings. Common. Much resembling the following. Bases of leaves usualiy green and whitish.

Plantago rugelii Dene. Rugel's plantain. About drellings, in waste places and cultivated grounds. Often plentiful. Much resembling the preceding. Petioles usually pinkish.

Plantago lanceolata I. English plantain. Becoming common as a weed in lawns, pastures and cultivated grounds.

\section{RUBIACEAE. Madder Family}

Galium trifidum I. Small bedstraw. Low damp open ground. ()ften abundant among grasses and sedges.

Galium tinctorium L. Stiff marsh bedstraw. Wild madder. Damp open or shaded ground. Plentiful.

Galium asprellum Michx. Rough bedstraw. Usually in damp ground climbing over willows and other shrubs. Common.

Galium triflorum Michx. Fragrant bedstraw. Abundant in hardwoods.

Milchella repens L. Partridge-berry. Twin-berry. Dryish wools, especially open hardwoods. Common. Ripe berries red. 
CAPRIFOLIACEAE. Honeysuckle Family

Diervilla lonicera Mill. (D. diervilla (L.) MacM.). Bush honeysuckle. Dry sandy open or shaded ground. Common.

Lonicera canadensis Marsh. American fly-honeysuckle. Damp woods and thickets. Common.

Lonicera oblongifolia (Goldie) Hook. Swamp fly-honeysuckle. Swamps in open or shade. Frequent.

Lonicera hirsuta Eat. Hairy honeysuckle. Usually in damp open or shaded ground. Apparently infrequent. A vine, and when favorably situated becomes a fine vigorous climber.

Lonicera dioica L. Glaucous honeysuckle. Dry open or shaded ground throughout. Frequent. Aiso a vine and good climber.

Linnaea borealis americana (Forbes) Rehder. (L. americana Forbes). Twin-flower. Woods and boggy places. Common, and often abundant.

Viburnum opulus americanum (Mill.) Ait. (V. opulus L.). Cranberry-tree. High-bush cranberry. Borders of woods and along streams but never abundant.

Viburnum cassinoides L. Withe-rod. Wild raisin. I)amp open or shaded ground. Abundant. When in full bloom, one of the most beautiful wild shrubs in the Upper Peninsula.

Viburnum lentago L. Nanny-berry. Open woods and banks of streams. Plentiful. Berries blue-black, palatable.

Sambucus canadensis L. Sweet elder. American elder. Open rich ground. Frequent throughout. In bloom September 14, 1915.

Sambucus racemosa L. Red-berried elder. Damp open or shaded ground. Common.

\section{VALERIANACEAE. Valerian Family}

Valeriana uliginosa (T. \& G.) Rydb. Wet swampy ground on margins of tamarack-black spruce swamps. Often abundant.

\section{CUCURBITACEAE. Gourd Family}

Echinocystis lobata (Michx.) T. \& G. (Micrampelis lobata (Michx.) Greene). Wild balsam apple. Banks of the Manistique River. Very probably an escape.

CAMPANULACEAE. Bluebell Family

Campanula rotundifolia L. Harebell. Blue bells of Scotiand. Mostly on the sandy beaches of Lake Michigan and Lake Superior. Plentiful.

Campanula aparinoides Pursh. Marsh hellflower. Damp grassy open ground throughout. Plentiful. 
LOBELIACEAE. Lobelia Family

Lobelia kalmii L. Kalm's lobelia. Brook lobelia. Bogs and clamp shores. Common.

\section{COMPOSITAE. Composite Family}

Eupatorium purpureum L. Joe-pye weed. Usually in low open ground, sometimes in rich damp open woods. Often abundant.

Eupatorium purpureum maculatum (L.) Darl. (E. maculatum I..). Spotted Joe-pye weed. Wet open ground. Often plentiful.

Eupatorium perfoliatum L. Boneset. Thoroughwort. Isow open ground. Common.

Liatris scariosa Willd. (Lacinaria scariosa (L.) Hill.). Large buttonsnakeroot. Dry open ground. Frequent. Often abundant on the jack pine plains.

Grindelia squarrosa (Pursh) Dunal. Broad-leaved gum-plant. Dry open ground in waste places and fields. Apparently an immigrant from the west. Occasional.

Solidago hispida Muhl. Hairy goldenrod. Dry open or partially shaded ground. Often abundant.

Solidago randii (Porter) Britton. Rand's goldenrod. Nostly on sandy beaches of Lake Michigan and Lake Superior. Common.

Solidago uliginosa Nutt. Swamp goldenrod. Boggy open ground throughout. Common.

Solidago juncea Ait. Farly goldenrod. Dry open or partially shaded ground. Frequent.

Solidago ulmifolia Muhl. Elm-leaved goldenrod. Dryish shaded ground. Frequent.

Solidago ruyosa Mill. Wrinkled-leaved goldenrod. Common in dry open or slightly shaded ground.

Solidago nemoralis Ait. Gray goldenrod. Dry open ground and often abundant.

Solidago canadensis L. Canada goldenrod. Rich damp or dry open or partially shaded ground. Common throughout.

Solidago altissima L. Tall goldenrod. Usually in rich open dryish ground. Common.

Solidago serotina Ait. Late goldenrod. In rieh open or shaded ground. Frequent.

Solidago houghtonii T. \& G. Houghton's goldenrod. Sandy beaches of Lake Michigan and Lake Superior. Frequent.

Solidago graminifolia (L.) Salisb. (Euthamia graminifolia Nutt.). Flat-topped goldenrod. Moist open ground and sandy shores. Common. Often a very slender form noticed, perhaps approaching s. tenuifolia Pursh. 
Aster macrophyllus L. Large-leaved aster. Open woods and thickets. Frequent and in spots abundant.

Aster multiformis Burgess. Various-leaved aster. Plentiful in open hardwoods near Indian Lake. Very probably in many other places. See Britton \& Brown's Illustrated Flora, Second edition, Vol. 3, page 413.

Aster lindleyanus T. \& G. Lindley's aster. Open and partially shaded damp places. Common.

Aster laevis L. Smooth aster. Dry mostly open ground. Often abundant on the jack pine plains.

Aster lateriflorus (L.) Britton. Calico aster. Thickets, damp open places and along streams. Often plentiful.

Aster tradescanti L. Tradescant's aster. Low open or partially shaded ground and along low banks of streams. Abundant.

Aster paniculatus Lam. Panickled aster. Damp open or partially shaded ground and in damp meadow-like places. Frequent.

Aster salicifolius Ait. Willow aster. Low open ground, damp sandy places, and borders of damp woods. Plentiful.

Aster junceus Lam. Rush aster. Bogs, wet marshy places and damp meadow-like ground. Abundant.

Aster puniceus L. Red-stalk aster. Low wet open or partially shaded ground throughout. Abundant. The most abundant aster so far noticed in the Upper Peninsula.

Aster umbellatus Mill. (Doellingeria umbellata (Mill.) Nees.). Tall flat-top white aster. Usually in moist shaded ground. Abundant.

Aster nemoralis Ait. Bog aster. Bogs and swamps. Often abundant.

Erigeron philadelphicus L. Common fleabane. Usually in damp open ground. A field weed and often abundant.

Erigeron annuus (L.) Pers. Sweet scabious. Fields and waste places. A frequent field weed.

Erigeron ramosus (Walt.) BSP. Daisy fleabane. Fields and roadsides. A common weed and often abundant.

Erigeron canadensis L. (Leptilon canadense (L.) Britton). Horseweed. Butter-weed. In gardens, fields and waste places. A common weed and often abundant.

Antennaria neodioica Greene. Smaller cat's-foot. Open dryish woods and dryish open ground. Frequent.

Antennaria neglecta Greene. Field cat's-foot. Dry open ground, dry open woods and generally on dry prairie-like ground. Often abundant. Antennaria petaloidea Fernald. Common cat's-foot. Dry banks, fields and open woods. Often plentiful.

Anaphalis margaritacea (L.) B. \& H. Pearly everlasting. Usually in dry open ground. Common.

Gnaphalium polycephalum Michx. (G. obtusifolium L.). Conımon 
everlasting. Sweet balsam. In dry or damp open ground. Apparently infrequent.

-Gnaphalium decurrens Ives. Clammy everlasting. Dry open ground especially in clearings. Frequent.

Gnaphalium uliginosum L. Low cudweed. In damp or dryish open ground. Often a field weed. Frequent.

Iva xanthifolia Nutt. Burweed marsh elder. West of Manistique near Cooks. Plants large and thrifty. Apparently introduced from the west. Not noticed elsewhere in Schoolcraft County.

A mbrosia trifida L. Great ragweed. In cities and villages as a weed. Not common.

Ambrosia artemisiifolia L. (A. elatior L.). Common ragweed. Becoming common as a weed in fields.

Ambrosia psilostachya DC. Western ragweed. Becoming established in cities and villages as a perennial weed.

Xanthium canadense Mill. (X. americanum Walt.). American cocklebur. As a weed in cities and villages. Apparently infrequent.

Rudbeckia hirta L. Yellow daisy. Black-eyed Susan. Dry open ground. Frequent and noticed in cultivated fields.

Lepachys columnaris (Sims) T. \& G. Prairie cone-flower. In cities, villages and along railroads. Introduced from the west and apparently infrequent. Cornell.

Bidens frondosa L. Beggar-ticks. Mostly a weed in damp open ground. Frequent.

Bidens cernua L. Nodding bur-marigold. In low wet ground and swamps. Often abundant.

Achillea millefolium L. Common yarrow. Open dryish ground everywhere. Mostly a weed.

Anthemis cotula. L. Mayweed. In cities, villages, on roadsides, and about dwellings. Often abundant.

Chrysanthemum pinnatifidum Lecoq. \& Lamotte. Ox-eye daisy. Becoming well established along roads, in pastures and all cultivated grounds.

Chrysanthemum balsamita tanacetoides Boiss. (C. balsamita L.). Costmary. Occasionally escaping to roadsides and persisting. Frequent.

Tanacetum vulgare L. Common tansy. Occasionally escaping to roadsides and persisting.

Tanacetum huronense Nutt. Lake Huron tansy. Sandy beaches of Lake Michigan and Lake Superior. Often plentiful.

Artemisia caudata Michx. Tall wormwood. Sandy beaches of lake Michigan and Lake Superior. Occasional on interior sand ridges. Plentiful.

Artemisia vulgaris L. Common mugwort. In waste places of cities and villages. Frequent. Occasional in open woods. 
Artemisia biennis Willd. Biennial wormwood. As a weed in damp ground about ciries and villages and along railroads. An immigrant from the west. Frequent.

Artemisia absinthium L. Common wormwood. On roadsides and about cities and villages as an escape from cultivation.

Petasites palmatus (Ait.) Gray. Palmate-leaved sweet colt's-foot. Damp open or shaded ground throughout. Frequent. W. T.S. Cornell.

Erechtites hieracifolia (L.) Raf. Fire-weed. Moist open or shaded ground. Often plentiful on burned over areas.

Senccio aureus I. Golden ragwort. In damp mostly shaded places throughout. Plentiful.

Senecio balsamitae Muhl. (S. pauperculus Michx.). Balsam groundsel. In dry open or partially shaded ground and along sandy beaches. Frequent.

Arctium minus Bernh. Common burdock. Waste places, roadsides, fields and open woods. Frequent.

Cirsium lanceolatum (L.) Hill. Common thistle. Roadsides, pastures and fields. Frequent.

Cirsium pitcheri (Torr.) T. \& G. Pitcher's thistle. Sandy beaches of Lake Michigan and Lake Superior. Frequent. Seldom abundant.

Cirsium discolor (Muhl.) Spreng. Field thistle. Rich open or shaded ground throughout. Frequent.

C'irsium muticum Michx. Swamp thistle. In swampy places and damp woods. Frequent.

Cirsium arvense (L.) Scop. Canada thistle. Roadsides, pastures and cultivated grounds. Becoming common.

Cichorium intybus L. Chicory. Occasional about cities and villages and in eultivated grounds. Frequent.

Tragopogon porrifolius L. Oyster plant. Escaping from cultivation to roadsicles and along railroads. Frequent.

Tragopogon pratensis L. Yellow goat's-beard. Waste places in cities and villages, Often plentiful.

Taraxacum officinale Weber. (Leontodon taraxacum L.). Common dandelion. Common everywhere. Abundant in fields and pastures.

Sonchus arvensis L. Corn sow-thistle. Along railroads, in depot grounds of cities and villages and becoming a weed on roadsides and in fields. Frequent.

Sonchus oleraceus L. Common sow-thistle. A weed in waste places, gardens and fields. Plentiful.

Sonchus asper (L.) Hill. Spiny-leaved sow-thistle. A weed in waste places, gardens and fields. Frequent.

Lactuca scariola integrata Gren. \& Godr. Prickly lettuce. I weed in waste grounds of cities and villages and becoming frequent. 
Lactuca canadensis $\mathrm{L}$. Wild lettuce. Rich open or partially shaded ground. Frequent.

Lactuca spicata (Lam.) Hitchc. 'Tall blue lettuce. Damp open or partially shaded ground. Common and often abundant.

Prenanthes racemosa Michx. (Nabalus racemosus (Michx.) DC.). Glaucous white lettuce. Damp open ground and in damp sand. Frequent.

Prenanthes alba. L. (Nabalus albus (L.) Hook.). Rattlesnake-root. White lettuce. Rich woods. Apparently infrequent.

Prenanthes altissima L. (Nabalus altissimus (L.) Hook.). Tall white lettuce. Rich shaded ground. Frequent. IV. T. S. Cornell.

Hicracium scabrum Michx. Rough hawkweed. Dry open or partially shaded ground. Frequent.

Hieracium canadense Michx. Canada hawkweed. Dryish ground, open or shaded. Frequent throughout. 

OBSERVATIONS ON THE WILD PLANTS AT WHITEFISH POINT AND VERMILION, NEAR THE SOUTH SHORE OF IAAKE SUPERIOR, AND OTHER PARTS OF CHIPPEWA COUNTY, MICHIGAN, IN 1914.

Considerable biological work having been done at Whitefish Point and near Vermilion in Chippewa County, Michigan, by the Michigan Geological and Biological Survey, it was determined to investigate the wild plants there as far as time would permit, referring only to flowering plants, ferns, and fern allies. The writer undertook the work in the summer of 1914. As far as possible other parts of the county were also visited.

\section{Region Specialliy Examined}

Special plant examination began at Eckerman east of Soo Junction, June 14, 1914; from this point north about 16 miles to Emerson on the Lake Superior shore, to Shelldrake about 12 miles farther north and west, and then to Whitefish Point and Vermilion about 15 miles farther north. In this whole distance, there are only a very few small clearings apparently long ago abandoned, and only a few little gardens. Lekcrman is a mere railway station; Emerson and Shelldrake, only lumbering and sawmill plants; Whitefish Point, a small postoffice; and Vermilion, a life-saving station. About 3 miles northeast of the postoffice is the United States lighthouse. A few fishermen operate along the shore from Emerson to the lighthouse. Just southeast of Eckerman on a ridge is a remarkable hardwood forest of beech, sugar maple, and bireh, yet intact. Scattered among the other trees are basswood, clm, and hemlock, specimens as large as the writer has ever seen. North about 6 miles is another hardwood forest, 8 miles wide and reported to be 40 miles long easterly and westerly. In these two harriwood forests, si) fir as could be examined, no lumbering to speak of has occurred, nor have they been visited by destructive fires. In the larger forests a few lumbering camps were reported, but not seen. Nearby on the south is an extensive cedar swamp, long ago lumbered over and abandoned and later visited by destructive fires. At present it is mostly a sort of jungle in a condition for more devastating fires. Also, just north and west is an extensive swamp of tamarack and black spruce, one at Emerson, and another at Shelldrake, all yet intact, not having been lumbered over nor visited by destructive fires. The trees are generally small and the tamaracks are being killed as explained in the annotated plant list. 
The swamps are often very wet and the ground covered with sphagnum. On their margins and in open spaces, Chamaedaphne calyculata, Andromeda glaucophylla, Ledum groenlandicum and Kalmia polifolia are abundant and are the dominant bog shrubs of the region. In spots two more swamp shrubs, Myrica gale and Betula pumila glandulijera, are plentiful. Along the lake shore generally, above Shelldrake around to Vermilion are sand dunes, covered mostly with jack pine, red maple and red oak. Some distance from the shore west to Luce County there are large areas of fixed sand ridges thinly covered mostly with small red pine and jack pine, much of the merchantable timber having long ago been cut. South of Vermilion as far as Shelldrake River, there is a region of large and high sand ridges formerly covered mostly with white pine and red pine, all of which have been cut except perhaps about a section of original forest of fine trees southwest of Vermilion. The lumbered portion has been visited by several destructive fires. In open places there are at present, where not too much shaded by small jack pines and other coniferous shrubs, extensive areas wall sodded over with Poa pratensis and Poa compressa, making good pasture lands. In spots Frunus pennslyzanica is abundant.

\section{Rivers and Small Lakes}

Two streams perhaps worthy of notice penetrate this locality. The Tahquamenon River which rises in Luce County on the west is much the larger. It passes in two places over precipitous rocks, known as the upper and lower falls, and enters Lake Superior at Emerson. The river was followed up as far as the lower falls, and the writer has never seen a more beautiful small stream. Along its banks elm and black ash are quite common. Shelldrake River rising near the west line of Chippewa County flows northerly toward Vermilion, then southeast, and enters the lake at Shelldrake. This was followed up about 17 miles west of Shelldrake where lumbering camps are at present established. Between these two rivers some distance from the lake, the sand ridges are large and high, and among them are many small lakes, ponds, and swamps.

\section{Ponds and Bogs Near the Lake Superior Shore}

From Whitefish Point to Vermilion, near and parallel with the Lake Superior shore, are many ponds and bogs often long and narrow, enclosed mostly by drifting sand dunes on the lake side and higher fixed sand ridges on the land side. Only a few of these have a natural outlet to the lake. Just south of Vermilion are a typical long pond and bog bordered by a tamarack and black spruce swamp and backed by high fixed sand ridges. These ponds and bogs are the natural home of many water plants and sedges. Here the locality and conditions being well-nigh 
perfect for that purpose, the late John Clark made a large and productive cranberry farm with modern appliances for flooding the land and collecting the crop. There is also a smaller cranberry farm at Whitefish Point owned by Mr. Trank House.

\section{The Region Wild and Nearly in Natural State}

The locality from Eckerman to Vermilion, and all that portion of the county north of the railway connecting soo Junction with Brimley ancl west to Luce County, is one of the wildest the writer has ever risiterl. If such a wild region is the proper place for biological work, this has been well chosen, and is typical. It is the home of such wild animals as have been left in Michigan. Bear tracks were common, deer and tiny fawn tracks, and their trails, were numerous. Porcupines were abundant, five having been seen at one time in an abandoned shanty. Its northern latitude was indicated on the night of June 13-14, 1914, by a killing frost, cutting down the common brake wherever exposed, and killing the tender shoots of small black ash and other shrubs and trees.

\section{Peculiar Habitats}

Throughout the locality there is much flat sandy land mostly in streaks with a thin covering of vegetable mold and sphagnum giving it a very swampy appearance. Growing on this were found white hirch, black ash, black spruce, balsam and red maple. Forest fires in dry seasons have swept over most of such ground and the dead timber is still standing. Back of Shelldrake was noticed a large area of flat sandy land covered with sphagnum, in which were growing only small scattering jack pines and an occasional small bunch of shrubs.

\section{Trees and Shrubs with Diverse Habitats}

As already intimated, black sprure mixed with tamarack is abundint in swamps throughout the county. But black spruce is also common over large tracts of flat, dry, sandy ground, especially so on the dry banks of the Tahquamenon River. In this respect, howerer, the behavior of red maple is much more striking. Cencral observation and the record in botanical works indicate as a halitat for this speries "swamps and wet woods", but in the whole region north and west of Eckerman it is very abundant on dry flat sandy land, fixed sand ridges and drifting sand dunes, although mostly reduced in size and scraggy in this situation. So far as heretofore observed by the writer in Michigan Ledum groenlandicum is a bog shrub, but here it extends from bogs to dry flat sandy land, and to sides and even crests of fixed samd ridges and drifting sand dunes. 


\section{Forests Known as Hardwoods}

These forests, composed about equally of beech, sugar maple, and yellow birch, have many peculiarities of their own. Scattered among the trees are here and there, basswood, American elm, hemlock, mountain maple, mountain ash, and balsam. Underneath, the American yew is very abmondant, as also are Clintonia borealis and Lycopodium annotinum. In spots Oxalis acetosella carpets the ground.

\section{Chippewa County as a Whole}

This county, starting on the south shore of Lake Supcrior at a point a few miles west of Vermilion, extends in a southeasteriy direction to the east end of Drummond Island, a distance approximating 100 miles on a straight line connecting these two extreme points. Its lake and river frontage is over 150 miles. That portion of the county not already mentioned,-the eastern, southern and southeastern parts-on the whole differs very materially from the northwestern. There are many sand ridges, numerous tamarack-black spruce swamps, white cedar swamps, many bogs, sma!l lakes and ponds. Large parts of the eastern portion were covered formerly with hardwood forests, and some pine in streaks mixed with hardwoods. But wasteful and destructive methods of lumbering, and devastating fires have changed the face of the county. The timber has been thus substantially removed. It is not, generally speaking, a rocky country. In the eastern portion boulders occasionally appear, and exposed rocks were noticed at Gatesville and from th $r$ re to Saint Marys River and Detour. These hardwood lands are being cleared for agricultural purposes. From Brimley to Sault Ste. Marie and from there south and east to Detour, about 65 miles, the road on both sides is lined with good farms almost without exception, all appearances indicating good soil, and thrift in the way of buildings and crops. Orchards were scarce, but a few heavily bearing apple trees were noticed. Corn fields were few. Wheat, barley, oats, peas, potatoes, timothy, and clover were the main crops. On September 10, 1914, much of the wheat, oats, anc! barley was in shock, and many fields of grain yet uncut. The change in appearance and apparent conditions from the western and northwestern to the eastern and southeastern parts is very great. This is over 300 miles direct north of the southern State boundary, so that a list of the wild plants growing here compared with one in Hillsdale County, directly sonth, would be interesting in the study of plant distribution.

\section{Acknowledgements}

The writer is much indebted to Mr. Kenneth K. Mackenzie of New York City for an examination and determination of the sedges, and 
other difficult plants. To Prof. A. S. Hitcheork of the L'nited States Department of Agriculture, for determination of grasses, and to F. F. Forbes of Brookline, Massachusetts, for an examination of the willows and violets. March 11, 1915.

Gray's New Manual of Botany has been followed as far as possible. Changes have been made and a number of new species established since its publication.

\section{Annotated List \\ POLYPODIACEAE. Fern Family}

Polypodium vulgare L. Common polypody. Shaded rocks in eastern portion of county. Plentiful.

Phegopteris polypodioides Fée. Long beech fern. In hardwoods throughout. Occasional.

Phegopteris dryopteris (L.) Fée. Oak fern. Beech and maple woods throughout Chippewa County. Common and often abundant.

Adiantum pedatum L. Maidenhair. Margins of and open spots in, beech-maple-birch woods. Frequent.

Pteris aquilina L. Common brake. Very abundant in open or slightly shaded ground. Where exposed it was killed to the ground by a severe frost on the night of June 13-14, 1914.

Asplenium filix-femina (L.) Bernh. Lady fern. Open and slightly shaded ground throughout. Common and often abundant.

Aspidium thelypteris (L.) Sw. Marsh shield fern. Borders of marshes and swamps and often in slight shade. Common and often very abundant.

Aspidium noveboracense (L.) Sw. New York fern. Abundant in beech-maple-lirch woods near the lower falls of the T'ahquamenon River back of Emerson. Occasional in all hardwood forests.

Aspidium marginale (L.) Sw. Evergreen wood fern. Rich open woods. Frequent.

Aspidium cristatum (L.) Sw. Crested shield fern. Wet open or shaded rich ground. Frequent.

Aspidium spinulosum (O. F. Müller) Sw. Spinulose shield fern. In beech-maple-birch woods throughout. Frequent.

Aspidium spinulosum intermedium (Muhl.) D. C. Eaton. American shield fern. Rich hardwoods. Common.

Cystopteris bulbifera (L.) Bernh. Bulblet cystopteris. Open woods. and on banks of streams. Occasional throughout.

Cystopteris fragilis (L.) Bernh. Brittle fern. Damp rich woods. Occasional.

Onoclea sensibilis L. Sensitive fern. Throughout in damp open or shaded ground. Common. 
Onoclea struthiopteris (L.) Hoffm. Ostrich fern. Abundant along the Tahquamenon River above Emerson near lower falls, and occasionally throughout. Fine specimens traced along streams.

Osmunda regatis $\mathrm{L}$. Royal fern. In wet and often shaded ground throughout. Common.

Osmunda claytoniana L. Interrupted fern. In rich open or slightly shaded ground throughout. Fine specimens noted.

Osmunda cinnamomea L. Cinnamon fern. Damp rich open or shaded ground throughout. Fine specimens.

\section{OPHIOGLOSSACEAE. Adder's Tongue Family}

Botrychium obliquum Muhl. Ternate grape fern. In sandy, slightly shaded ground near Whitefish Point. Apparently rare.

Botrychium virginianum (L.) Sw. Rattlesnake fern. Common throughout in woods and thickets.

\section{EQUISETACEAE. Horsetail Family}

Equisetum arvense L. Common horsetail. Common throughout. Often on sand dunes acting as a sand binder.

Equisctum sylvaticum I. Wood horsetail. Damp ground in swamps and along streams. Abunclant throughout.

Equisetum fluviatile. Pipes. Wet open places, shallow water, ditches and swamps. Often abundant.

Equisetum hyemale L. Common scouring rush. Often on sides of sand dunes where it acts as a good sand binder. Common in dry, sandy, open ground.

Equisetum variegatum Schleich. Variegated equisetum. Sandy beaches of Lake Superior, often acting as a sand binder. Frequent.

Equisetum scirpoides Michx. Sedge-like equisetum. In woods and open places in tamarack-black spruce swamps. Frequent.

\section{LYCOPODIACEAE. Club Moss Family}

Lycopodium lucidulum Michx. Shining club moss. Damp woods throughout. Abundant near lower falls of the Tahquamenon River above Emerson.

Lycopodium inundaium L. Bog club moss. Usually in open damp sandy ground. Plentiful.

Lycopodium annotinum I. Stiff club moss. Beech-maple-birch woods. Very abundant throughout.

Lycopodium clavatum L. Common club moss. Dry open woods and steep banks of streams. Occasional throughout.

Lycopodium obscurum L. Ground pine. Beech-maple-birch woods. Frequent. 
Lycopodium complanatum L. Running pine. Pine woods and sand dunes throughout. Frequent.

Lycopodium tristachyum Pursh. Clustered ground pine. Dry open ground. Apparently infrequent.

\section{SELAGINELLACEAE. Selaginella Family}

Selaginella apus (L.) Spring. Creeping selaginella. Low open or partially shaded ground. Frequent throughout.

\section{TAXACEAE. Yew Family}

Taxus canadensis Marsh. American yew. Beech-maple-birch woods. Abundant, often carpeting the ground. Noticed in particular in the hardwoods north of Eckerman.

\section{PINACEAE. Pine Family}

Pinus strobus L. White pine. Formerly large areas covered with this species, as at present shown by stumps both on level sandy land, and sand ridges. Often mixed with red pine. Large specimens free from limbs and containing several logs of 16 feet each are called by land cruisers "sap pine", and specimens with limbs on the body nearly to ground, "buckwheat pine". Many small trees yet standing and seedlings usually plentiful. About a half section of original trees of this mixed with some red pine noticed yet standing southwest of Vermilion.

Pinus banksiana Lamb. Jack pine. Throughout the county on level sandy land and sand ridges. Abundant at Whitefish Point. Trees usually small, occasionally large enough for saw logs. Often mixed with red pine. Shrubs and seedlings abundant. Occasional in sphagnum swamps.

Pinus resinosa Ait. Red pine. Formerly plentiful and abundant in spots on dry flat sandy land and sand ridges. A few fine trees yet left, scattered over the county. A large area of sand ridges covered with small trees a few miles west of Emerson. A tree with a long body free from limbs, containing several logs of 16 feet each, called "ycllow pine" by land cruisers; one with limbs nearly to the ground, "huckwheat pine". When logs of this species are so heavy as to sink in water many lumbermen call it "pigiron pine".

Larix laricina (DuRoi) Koch. Tamarack. Many large swamps covered thickly with this and black spruce, throughout the county, usually referred to as "tamarack-black spruce swamps". Trees generally small and everywhere dying, being attacked by a winged insect from Europe called a saw fly. Shrubs and seedlings plentiful and apparently vigorous. "Tamaracks are being killed all over the State now by a saw fly that came to this country from Europe before the Civil War. 
It gradually worked its way westward and arrived in Michigan som? ten years ago or thereabout. The naked larva which feeds on the leaves in June and July, when full grown, goes to the ground and pupates just under the surface. The creature being from Europe has no natural enemies or very few of them to control it here, and therefore the death rate of tamaracks has been very high. It usually is followed by a bark beetle which works between the bark and the wood and which is itself capable of killing trees. The name of this saw fly is Lygaeonematus erichsoni, and the name of the beetle that works under the bark is Denbroctonus simitis. We have been spending some effort for a number of years trying to introduce the European parasites which control this pest in its native home and while we have not succeded in establishing the European species we have some little hopes from an unknown species which we have succeeded in getting several times. There is nothing that can be done particularly."-B. H. Pettit, Professor of Entomology, Michigan Agricultural College, February 18, 1915.

Picea canadensis (Mill.) BSP. White spruce. Scattering throughout along Lake Superior shore and on sand ridges. Often affected with a pest known as dwarf mistletoe.

Picea mariana (Mill.) BSP. Black spruce. Large areas of this mixed with tamarack growing in wet swampy ground throughout the county. Trees mostly small. Often growing on higher ground, where it is larger and cut for pulpwood. A form of it common on dry sanrly land everywhere, and on sand ridges, which some botanists would name P. brevifolia Peck, swamp spruce. Twigs of this and Abies balsamea near Lake Superior shore above Shelldrake, are covered with a bearded lichen, Usmea barbata plicata Ehrh., giving the trees a shaggy and moss-like appearance similar to more northern forests. Often afficted with the dwarf mistletoe.

Abies balsamea (I.) Mill. Balsan fir. Common throughout the county and abundant in spots. Frequent with beech, maple and birch, and occasional in swamps with tamarack and black spruce. A very beautiful forest tree.

Tsuga canadensis (L.) Carr. Hemlock. Common throughout but seldom abundant except in streaks or small spots. Frequent with hard maple, yellow birch, and beech. Trees often very large, one recently cut indicating an age of over 300 years. Large trees called "yellow hemlock" by land cruisers; second growth, "white hemlock".

Thuja occidentalis L. Arhor vitae, white cedar. Formerly very abundant throughout the county in cedar swamps which have been lumbered over for many years and mostly destroyed by fire. Small trees and seedlings yet abundant. Often growing on sandy ground especially near the Iake Superior shore, but it is usually small in such situations. Shrubs and seedlings abundant. As understood by land cruisers, second growth trees anci trees covered with limbs to or nearly to the ground 
are "white cedar". Trees with tall smooth bodies without many body limbs and with small tops, are "yellow cedar".

Juniperus communis depressa Pursh. Low juniper. Sand dunes, sand ridges, and sandy beaches throughout but seldom abundant. Noticed as more common on rocky ground near Detour.

Juniperus horizontalis Moench. Creeping juniper. Abundant in very wet ground growing at the bases of small tamaracks and spruces on the border of a tamarack-black spruce swamp north of Eekerman. Heretofore noticed only on small sand ridges, and sandy beaches, near shores of Lake Huron and Iake Michigan.

Juniperus virginiana L. Red cedar. Reported as on sand dunes near Vermilion, but believed to be very doubtful, except possibly as a casual escape.

TYPHACEAE. Cat-tail Family

Typha latifolia L. Common cat-tail. Common throughout in swampy open places.

\section{SPARGANIACEAE. Bur-reed Family}

Sparganium eurycarpum Engelm. Broad fruited bur-reed. Marshy places, borders of ponds and slow streams. Common throughout.

Sparganium diversifolium acaule (Beeby) Fernald and Fames. Stemless bur-reed. Swampy open ground near Vermilion. Apparently infrequent. N. A. Wood.

NAJADACEAE. Pondweed Family

Potamogeton natans L. Common floating pondweed. Ponds and slow streams throughout. Common.

Potamoyeton epihydrus Raf. Nuttall's pondweed. Slow creeks, ponds, and ditches throughout. Often abundant.

Potamogeton heterophyllus Sehreb. Various leaved pondweed. Slow streams and ponds throughout. Frequent.

Potamogeton angustifolius Berchtold and Presl. Ziz's pondweed. Small lakes or large ponds throughout. Also noticed in the T'ahquamenon River near lower falls above Emerson. Frequent.

Potamogeton lucens I. Shining pondweed. In Little Lake at Whitefish Point. Plentiful. Noticed by T. L. Hankinson, ichthyologist.

Potamogeton pusillas L. Snall pondweed. Ponds, pools and ditches throughout. Common.

Potamogeton rutilus Wolfgang. Slender pondweed. In I.ittle l.ake at Whitefish Point. Plentiful. Noticed by T. I. Hankinson, ichthyologist.

Potamogeton foliosus Raf. Leafy pondireed. In nearly still water of 
Tahquamenon River near lower falls above Emerson. Plentiful at this place.

Polamogeton dimorphus Raf. Spiral pondweed. Tahquamenon River near lower falls above Emerson. Plentiful.

Najas fiexitis (Willd.) Rostk. \& Schmidt. Slender najas. Ponds, small lakes, and margins of slow streams. Plentiful.

\section{JUNCAGINACEAE. Arrow Grass Family}

Scheuchzeria palustris L. Scheuchzeria. Open boggy places throughout. Abundant near Vermilion.

Triglochin maritima L. Sea-side arrow-grass. Marshy open places throughout. Frequent.

Triglochin palustris I.. Marsh arrow-grass. Damp open sandy ground thronghout. Plentiful at Vermilion.

\section{ALISMACEAE. Water-plantain Family}

Sayittaria latifolia Willd. Broad-leaved arrow-head. MIuddy places, and shallow water in ponds and ditches and slow streams throughout. Common.

Alisma plantago-aquatica L. American water plantain. In shallow water, muddy places, and ditches throughout. Common.

HYDROCHARITACEAE. Frog's Bit Family

Elodea canadensis Michx. Waterweed. Ponds, small lakes, and slow streams. Plentiful throughout.

Vallisneria spiralis L. Tape grass. Wild celery. Ponds and slow streams throughout. Common.

\section{GRAMINEAE. Grass Family}

Andropogon scoparius Michx. Broom beard grass. Dry open ground or among pines. Frequent.

Andropogon furcatus Muhl. Forked beard grass. Dry open ground. Apparently infrequent.

Digitaria humifusa Pers. Small crab grass. Sandy open ground in and about Sault Ste. Marie. Plentiful.

Digitaria sanguinalis (L.) Scop. Crab grass. Cultivated grounds and about villages as a weed. Not abundant.

Panicum capillare L. Old-witch grass. About cultivated grounds and in villages as a weed. Apparently not abundant.

Panicum depauperatum Muhl. Starved panic grass. On lumbered over and burnt over sand ridges south of Vernilion. Apparently not common.

Panicum subvillosum Ashe. Spreading panic grass. Open sandy 
ground near Shelldrake River south of Vermilion. Apparently infrequent.

Echinochloa crusgcili (L.) Beauv. Barnyard grass. In damp cultivated grounds and about villages. Apparently not common.

Setaria glauca (I.) Beauv. Foxtail. Pigeon grass. Cultivated grounds and in cities and villages as a weed. Apparently not very common.

Setaria viridis (L.) Beauv. Green foxtail. A weed in cultivated fields and villages. Not ahundant.

Cenchrus carolinianus Walt. Sandbur. Bur-grass. Open sandy ground in and about Sault Ste. Marie. Plentiful.

Leersia oryzoides (L.) Sw. Rice cut-grass. Seratch grass. Swamps and along low banks of strams and in old ditches. Frequent.

Phalaris arundinacea L. Reed canary grass. Wet open ground. Frequent.

Milium effusum I. Millet grass. Beech-maple-birch woods. Common throughout.

Oryzopsis asperifolia Michx. White grained mountain rice. Beechbirch-maple woods throughout. Frequent.

Muhlenbergia racemosa (Michx.) BSP. Wild timothy. Satin grass. Moist meadow-like places. Frequent throughout.

Brachyelytrum erectum (Schreb.) Beauv. Bearded short-husk. Becchbireh-maple woods throughout. Plentiful.

Phleum pratense L. Timothy. Common throughout in both damp and dry open ground.

Alopecurus geniculatus aristulatus Torr. Short awned foxtail. In very wet places and shallow water. Frequent.

Sporobolus uniforus (Muhl.) Scribn. and Merr. Late-flowering dropseed. Damp open ground. Plentiful at Emerson. Apparently infrequent.

Sporobolus cryptandrus (Torr.) Gray. Sand drop-seed. Sandy ground near and on the beaches of Lake Superior. Frequent. Never abundant.

Agrostis alba L. Red-top. Damp meadow-like ground throughout but nowhere abundant.

Agrostis hyemalis (Walt) BSP. Hair grass. Dry or moist open ground throughout. Often plentiful.

Agrostis perennans (Walt) Tuckerm. Thin-grass. In damp woods throughout. Plentiful in woods at lower falls of the Tahquamenon River back of Emerson.

Calamovilfa longifolia (Hook.) Hack. Long-leaved reed-grass. Sandy shores of Lake Superior but nowhere abundant. A good sand binder, when plentiful and well established.

Calamagrostis canadensis (Michx.) Beauv. Blue joint-grass. Damp open marshy ground. P'lentiful throughout. 
Ammophila arenaria (L.) Link. Sea sand-reed. Sandy beech of Lake Superior. Often abundant and acting as an efficient sand binder.

Cinna latifolia (Trev.) Griseb. Slender wood reed-grass. Beechmaple-birch woods throughout. Plentiful.

Koeleria cristata (I.) Pers. Crested hair-grass. Dry open ground. Frequent.

Deschampsia flexuosa (L.) Trin. Common hair grass. Dry open or slightly shaded places near Vermilion. Frequent in that region.

Avena sativa L. Common oat. Escaping and apparently persisting in many places near dwellings, and about villages.

Danthonia spicata (L.) Beauv. Common wild oat grass. Dry open ground, but not abundant.

Danthonia intermedia Vasey. Vasey's wild oat grass. Dry open ground near Vermilion. Apparently infrequent.

Phragmites communis Trin. Reed. Margins of, and open places in, tamarack-black spruce swamps throughout but nowhere very abundant.

Eragrostis pilosa (L.) Beauv. Small tufted love grass. Dry open ground in and about Sault Ste. Marie. Plentiful.

Eragrostis megastachya (Koeler) Link. Strong scented love grass. Gardens and other cultivated grounds. Occasional.

Melica smithii (Porter) Vasey. Smith's oat. Open places in keechmaple-birch woods near Erkerman. Apparently not common.

Melica striata (Michx.) Hitche. Purple oat. Borders of, and open places in, beech-maple-l)irch woods throughout, but apparently not common.

Dactylis glomerata L. Orchard grass. In and near cities and villages and in cultivated grounds. Frequent.

Poa annua L. Low spear grass. Cultivated grounds and about villages. Frequent. Often abundant in lawns.

Poa compressa L. Canada blue grass. In dry open ground throughout. Noticed in particular on lumbered over and burned over sandridges where it was often abundant.

Foa nemoralis L. Wood meadow grass. Dry open ground near Vermilion. Apparently infrequent.

Poa pratensis L. June grass. Frequent and often abundant throughout the county. Noticed in particular on lumbered over and burned over sand ridges where it made good grazing.

Glyceria canadensis (Michx.) Trin. Rattlesnake grass. Damp meadow-like ground and along margins of small streams throughout. Often abundant. A beautiful grass.

Glyceria nervata (Willd.) Trin. Fowl meadow grass. Open damp or slightly shaded ground throughout. Often abundant.

Glyceria grandis Wats. Reed meadow grass. Along streams and in very wet places throughout. Plentiful. 
Festuca ovina I. Sheep's fescue. In open sandy ground at Whitefish Point. Apparently not common.

Bromus secalinus L. Chess. In cultivated gronnds and about villages. Not abundant.

Bromus ciliatus L. Fringed brome grass. In damp open or slightly shaded ground throughout. Noticed in particular as very abundant in open spots of beech-maple-birch woods at the lower falls of the Tahquamenon River above Emerson.

Agropyron molle Rydb. Rydberg's wheat grass. Dry open ground near Vermilion. Apparently infrequent. N. A. Wood. Identificd by Prof. A. S. Hitchcock.

Agropyron repens. (L.) Beauv. Quack grass. Becoming common throughout about dwellings and farm buildings, and in villages.

Agropyron dasystachyum (Hook.) Scribn. Northern wheat grass. Sandy beach of Lake Superior. Apparently infrequent (?).

Hordeum jubatum L. Squirrel-tail grass. Introduced at Sault ste. Marie and in villages.

Elymus virginicus L. Virginia wild rye. Moist woods and banks of streams throughout but not very common.

Elymus canadensis L. Nodding wild rye. Sandy beaches of Lalie Superior, acting as an efficient sand binder. Common.

Elymus gleucus Buckley. Smooth wild rye. Shaded banks of Tahquamenon River near lower falls back of Emerson. Apparently infrequent.

Elymus arenarius L. Sea lyme grass. Sandy beach of Lake Superior at Vermilion. Said to be a good sand binder. Not abundant and not noticed elsewhere in Michigan by the writer. (1914.)

Hystrix patula Moench. Bottle-brush grass. Open hardwoods. Apparently infrequent.

\section{CYPERACEAE. Sedge Family}

Dulichium arundinaceum (L.) Britton. Dulichium. Wet swampy places and borders of ponds throughout. Plentiful.

Eleocharis palustris (L.) R. \& S. Creeping spike rush. Wet meadowlike ground and often in shallow water. Common throughout.

Eleocharis palustris vigens Bailey. Large spike rush. Usually in shallow water about ponds throughout. Common.

Eleocharis acicularis (L.) R. \& S. Needle spike rush. Wet and muddy places about ponds and on margins of slow streams throughout. Plentiful.

Scirpus hudsonianus (Michx.) Fernald. Alpine cotton grass. Wet open marshy places. Abundant in spots throughout.

Scirpus americanus Pers. Three-square. Margins of ponds and streams throughout. Common. 
Scirpus validus Vahl. Great bulrush. Margins of ponds throughout. Frequent.

Scirpus occidentalis (Wats.) Chase. Viscid great bulrush. Very wet marshy places and in shallow water throughout. Common.

Scirpus atrovirens Muhl. Dark-green bulrush. Marshy open places and in swamps throughout. Common and in spots abundant.

Scirpus cyperinus pelius Fernald. Wool grass. Wet open meadowlike ground, and often in slight shade. Common throughout.

Scirpus atrocinctus Fernald. Dark wool grass. In open meadowlike ground and swamps with slight shade. Frequent throughout.

Scirpus atrocinctus brachypodus Fernald. Clustered wool grass. In meadow-like ground near Vermilion. Abundant. N. A. Wood.

Eriophorum callitrix Cham. Hare's tail. Open bogs. Common throughout.

Eriophorum gracile Poth. Slender cotton grass. Open bogs and swamps throughout. Abundant in one place near the lighthouse at Whitefish Point.

Eriophorum tenellum Nutt. Pough cotton grass. Occasional in open wet and swampy places throughout. Plentiful near Vermilion.

Eriophorum angustifolium Roth. Tall cotton grass. Wet boggy places throughout. Plentiful near Vermilion.

Eriophorum viridi-carinatum (Engelm.) Fernald. Thin leaved cotton grass. Borders of, and open spots in, tamarack-black spruce swamps. Common throughout.

Eriophorum virginicum L. Virginia cotton grass. Open bogs and wet meadow-like ground. Common throughout.

Rynchospora alba (L.) Vahl. White beak rush. Wet boggy open ground throughout. Common.

Cladium mariscoides (Muhl.) Torr. Twig rush. Bogs and very wet. sandy ground. Frequent.

Carex scoparia Schkuhr. Pointed broom sedge. Open damp or dryish ground throughout. Frequent

Carex tribuloides Wahlenb. Blunt brown sedge. Wet places and damp meadow-like open ground. Frequent throughout.

Carex siccata. Dewey. Hillside sedge. Dry open sandy ground. Occasional throughout.

Carex crawfordii Fernald. Crawford's sedge. Dry open ground at Emerson, Vermilion and Whitefish Point. Plentiful.

C'arex albolutescens Schwein. Greenish-white sedge. Damp or dryish ground near Emerson, Whitefish Point and Vermilion. Plentiful.

Carex tenera Dewey. Straw sedge. Dry open spots in woods near lower falls of the Tahquamenon River above Emerson. Apparently infrequent. 
Carex bebbii Olney. Bebb's sedge. Low and dryish ground near Emerson and Vermilion. Plentiful.

Carex aenea Fernald. Fernald's hay sedge. Dry ground, espécially lumbered over and burned over sand ridges near Vermilion. Frequent.

Carex adusta Boott. Browned sedge. Dry open ground near Emerson. Apparently not common.

Carex stellulata Good. Little prickly sedge. Open low and damp ground. Common throughout.

Carex leersii angustata (Carey) Mackenzie. Tapering serlge. Open low ground near Emerson. Apparently infrequent.

Carex sterilis Willd. (C. scirpoides Schk.). Prickly sedge. Damp open ground near Eckerman and Vermilion. Plentiful.

Carex canescens disjuncta Fernald. Disjointed sedge. Wet open ground near Emerson and Vermilion. Plentiful.

Carex trunnescens Poir. Brownish sedge. Dry open ground near Vermilion. Apparently infrequent.

Carex deweyana Schwein. Dewey's sedge. Beech-maple-birch woods throughout. Frequent.

Carex trisperma Dewey. Three-fruited sedge. Tamarack-black spruce swamps throughout. Common.

Carex tenella Schkuhr. Soft-leaved sedge. Margins and open places of tamarack-black spruce swamps throughout. Common.

Carex vulpinoidea Michx. Fox sedge. Damp open ground near lower falls of the Tahquamenon River back of Emerson. Apparently infrequent.

Carcx diandra Schrank. Lesser panicled sedge. Open bogs and wet prairie-like ground throughout. Common.

Carex stipata Muhl. Awl-fruited sedge. Very wet and open boggy ground. Common throughout.

Carex sartwellii Dewey. Sartwell's sedge. Boggy open ground. Frequent.

Carex chordorrhiza L.f. Creeping sedge. IVet grassy ground, and boggy places about ponds throughout. Abundant at Emerson, Whitefish Point and Vermilion.

Carex crinita Lam. Fringed sedge. Wet and usually shaded ground throughout. Common.

Carex aquatilis substricta Kükenthal. Smaller water sedge. Very wet open places throughout. Common.

Carex stricta Lam. Tussock sedge. Very wet open or slightly shaded places. Common.

Carex aurea Nutt. Golden-fruited sedge. Grassy ineadow-like ground. Frequent.

Carex hassei Bailey. Hasse's sedge. Gravelly shore of Lake Superior. Frequent. 
Carex pauciflora Lightf. Few-flowered sedge. Open places in tamarack-black spruce swamp at Vermilion growing in deep sphagnum. Apparently infrequent.

Carex leptalea Wahlenb. Bristle-stalked sedge. Bogs and wet open meadow-like ground. Common throughout.

Carex polygama Schkuhr. Brown sedge. Bogs and wet prairie-like ground throughout. Common.

Carex gracillima Schwein. Graceful sedge. Beech-maple-birch woods throughout. Common.

Carex communis Bailey. Fibrous-rooted sedge. Beech-maple-birch woods throughout and frequent.

Carex pennsylvanica I.am. Pennsylvania sedge. Dry open ground, especially on lumbered over and burned over sand ridges. Common.

Carex livida (Wahlenb) Willd. Iivid sedge. Wet marshy open ground throughout.

Carex paupercula Michx. Bog sedge. Boggy open ground near Vermilion and Emerson. Frequent.

Carex limosa L. Mud sedge. Boggy open ground and very wet sand throughout. Abundant near Whitefish Point and Vermilion.

Carex laxiflora leptonervia Fernald. Two-edged sedge. Damp places on border of beech-maple-birch woods throughout. Often abundant.

Carex flava L. Yellow sedge. Damp marshy places. Common.

Carex flava rectirostra. Gaudin. Small yellow sedge. Open wet marshy ground throughout. Frequent.

Carex oederi Retz. Green sedge. Bogs, damp meadow-like ground and in damp sand near shores. Frequent throughout.

Carex arctata Boott. Drooping wood sedge. Beech-birch-maple woods throughout. Frequent.

Carex debilis rudgei. Bailey. Rudge's sedge. Lumbered over and burned over sand ridges near Vermilion. Frequent.

Carex scabrata Schwein. Rough sedge. Damp open ground near Eckerman and Emerson. Frequent.

Carex filiformis L. Slender sedge. Open bogs and wet marshes throughout. Abundant.

Carex lanuginosa Michx. Woolly sedge. Low wet open ground, often in wet sand. Frequent.

Carex houghtonii Torr. Houghton's sedge. Dry open ground near Vermilion. Apparently infrequent.

Carex oligosperma Michx. Few-seederl sedge. Open bogs and very wet marshes throughout. Often aluundant.

C'arex hystericina Muhl. Porcupine sedge. Very wet marshy ground. Common throughtont.

Carex retrorsa Sehwein. Retrorse sedge. Wet open or slightly shaded ground throughout. Frequent. 
Carex intumescens Rudge. Bladder sedge. Beech-maple-birch woods throughout. F'requent.

Carex folliculata L. Long sedge. Damp ground on margins of woods and open places in tamarack-black spruce swamps. Plent iful throughout.

Carex michauxiana Boeckl. Yellowish sedge. Open brgss and very wet places throughout. Common.

Carex mainensis Porter. Maine sedge. Damp open ground near Whitefish Point. Apparently infrequent. See Britton and Brown, 2nd Edition, Vol. 1, page 432.

Carex vesicaria monile (Tuckerm) F'ernald. Necklace sedge. Damp open ground near Vermilion. Apparently infrequent.

Carex rostrata utriculata (Boott) Bailey. Beaked sedge. Tery wet open places throughout. Common.

Carex tuckermani Dewey. Tuckerman's serlge. Rich open ground near Tahquamenon River at Emerson. Not common.

ARACEAE. Arum Family

Arisaema triphyllum (L.) Schott. Indian turnip. Jack-in-the-pulpit. Beech-maple-birch woods throughout. Common.

Symplocarpus foetidus (I.) Nutt. Skunk cabbage. Wet ground near Emerson. Apparently rare.

\section{ERIOCAULACEAE. Pipewort Family}

Eriocaulon articulatum (Huds.) Morong. Seven-angled pipewort. On borders of ponds and in shallow water throughout. Abundant near Whitefish Point.

\section{PONTEDERIACEAE. Pickerel-weed Family}

Pontederia cordata L. Pickerel-weed. In shallow water of ponds and small lakes throughout. Frequent.

\section{JUNCACEAE. Rush Family}

Juncus bufonius L. Toad rush. Damp open ground throughout. Common.

Juncus tenuis Willd. Slender rush. In open ground throughout. Common.

Juncus greenei Oaks \& Tuckerm. Green's rush. Open sandy ground near Lake Superior shore at Vermilion. Apparently infrequent.

Juncus balticus littoralis Fngelm. Baltic rush. Frequent on sandy heach of Lake Superior as an efficient sand binder, and occasionally in low damp ground throughout.

Juncus effusus L. Common rush. Soft rush. Marshy open ground. Common throughout. 
Juncus brachycephalus (Engelm.) Buchenau. Small-headed rush. Marshy open places throughout. Plentiful near Vermilion.

Juncus brevicaudatus (Engelm.) Fernald. Narrow panicled rush. Wet and muddy places throughout. Plentiful near Vermilion.

Juncus canadensis J. Gay. Canada rush. Low marshy open ground. Plentiful throughout.

Juncus pelocarpus Miey. Brown-fruited rush. Swampy open places throughout. Plentiful near Vermilion.

\section{LILIACEAE. Lily Family}

Tofieldia glutinosa (Michx.) Pers. Glutinous tofieldia. Marshy open ground throughout. Abundant near Eckerman.

Allium tricoccum Ait. Wild leek. Beech-birch-maple woods throughout and often plentiful.

Erythronium americanum Ker. Yellow adder's tongue. Beechmaple-birch woods throughout. Seldom abundant.

Clintonia borealis (Ait.) Raf. Yellow clintonia. Very abundant throughout in beech-maple-birch woods.

Smilacina racemosa (L.) Desf. False spikenard. Beech-maple-birch woods throughout. Common.

Smilacina stellata (L.) Desf. Star-flowered Solomon's seal. Moist open or slightly shaded ground, and also sandy open or shaded places throughout. Often plentiful.

Smilacina trifolia (L.) Desf. Three-leaved Solomon's seal. In bogs and wet open places throughout. Abundant near Vermilion.

Maianthemum canadense Desf. Wild lily-of-the-valley. Beech-maplebirch woods throughout. Often abundant.

Streptopus amplexifolius (L.) DC. Clasping-leaved twisted-stalk. Borders of woods in damp ground and along banks of streanıs. Often in shade. Frequent throughout.

Streptopus roseus Michx. Sessile-leaved twisted-stalk. Beech-maplebirch woods throughout. Plentiful.

Streptopis longipes Fernald. Long-stemmed twisted-stalk. Beechmaple-birch woods. Frequent.

Polygonatum biflorum (Walt.) Ell. Hairy Solomon's seal. Beechmaple-birch woods throughout. Plentiful.

Medeola virginiana L. Indian cucumber-root. Beech-mapie-birch woods throughout. Plentiful.

Trillium cernuum L. Nodding wake-robin. Beech-maple-birch woods, throughout. Frequent.

\section{IRIDACEAE. Iris Family}

Iris versicolor L. Large blue flag. Open wet ground throughout, but seldom abundant. 


\section{ORCHIDACEAE. Orchis Family}

Cypripedium parviflorum Salisb. Smaller yellow lady's slipper. ITot swampy ground throughout.

Cypripedium parviflorum pubescens (Willd.) Knight. Larger yellow lady's slipper. Rich shaded ground. Frequent throughout.

Cypripedium acaule Ait. Stemless lady's slipper. Tamarack-black spruce swamps in sphagnum throughout, but never abundant. Also in shaded sandy ground.

Habenaria bracteata (Willd.) R.Br. Long-bracted orchis. Damp open woods. Frequent.

Habenaria hyperborea (L.) R.Br. Tall leafy green orchis. Damıp hardwoods. Frequent.

Habenaria dilatata (Pursh) Gray. Tall white bog orchis. Open wet and boggy places throughout. Frequent.

Habenaria clavellata (Michx.) Spreng. Boggy wet open ground. Irequent. Shaded swampy ground especially in tamarack-black spruce swamps. Frequent throughout.

Habenaria hookeri Torr. Hooker's orchis. Dry shaded ground. Apparently infrequent.

Habenaria orbiculata (Pursh) Torr. Round-leaved orehis. Rich shaded ground near Vermilion. Apparently infrequent. N. A. Wood.

Pogonia ophioglossoides (L.) Ker. Rose pngonia. Open wet boggy ground near Vermilion. Not common.

Calopogon pulchellus (Sw.) R.Br. Grass pink. Open wet and boggy places near Vermilion. Apparently not common. N. A. Wood.

Arethusa bulbosa L. Dragon's mouth. Open bogs at Vermilion. Probably frequent throughout but overlooked.

Spiranthes cernua (L.) Richard. Nodding ladies' tresses. Boggy open places and wet open ground generally. Frequent.

Epipactis repens ophioides (Fernald) A. A. Waton. Lesser rattlesnake plantain. Rich ground and on old mossy logs in beech-maplebirch woods throughout. Frequent.

Epipactis decipicns (Hook.) Ames. Menzie's rattlesnake plantain. Dryish open or slightly shaded places, often in rich ground. Plentiful throughout.

Listera cordata (L.) R.Br. Heart-leaved twayblade. Very wet and swampy place near Vermilion. Apparently infrequent, probably overlooked.

Listera convallarioides (Sw.) Torr. Broad-lipped twayblade. Damp places in hardwoods. Frequent but seldom abundant. 


\section{SALICACEAE. Willow Family}

Salix lucida Muhl. Shining willow. Damp open ground throughout. Common.

Salix lucida intonsa Fernald. Bearded shining willow. Damp open ground at Eckerman. Apparently infrequent.

Salix alba L. White willow. Occasionally planted but not noticed as an escape.

Salix longifolia Muhl. Sand bar willow. Along small streams and in sandy ground. Frequent.

Salix glaucophylla Bebb. Broad-leaved willow. Sandy open ground on or near sandy beach of Lake Superior. Frequent.

Salix balsamifera Barratt. Balsam willow. Wet bushy places and border's of tamarack-black spruce swamps at Vermilion and Emerson. Plentiful.

Salix syrticola Fernald. Furry willow. In sandy ground near and on the beach of Lake Superior. Frequent.

Salix pedicellaris Pursh. Bog willow. Open wet and boggy places throughout. Common.

Salix discolor. Muhl. Glaurous willow. Damp open ground and along streams. Common.

Salix petiolaris Sm. Slender willow. Damp open ground and often in clamp sand. Abundant throughout.

Salix humilis Marsh. Prairie willow. Dry open ground on sand dunes and lumbered over and burned over sand ridges. Plentiful.

Salix rostrata Richards. Beaked willow. Usually on dryish open ground throughout. Plentiful.

Salix candida Flügge. Sage willow. Open wet and boggy places throughout. Common.

Populus alba L. White poplar. Occasionally planted but not noticed as spreading.

Populus tremuloides Michx. American aspen. Noticed in this region only in dry or sandy ground. Scarce at Eckerman, Emerson, Shelldrake, Whitefish Point and Vermilion. Seldom abundant anywhere in the county.

Populus grandidentata Michx. Large-toothed aspen. Throughout the county but nowhere very common.

Populus baisamifera L. Balsam poplar. Throughout the county, trees often large. Plentiful.

Porulus deltoides Marsh. Large-leaved poplar. Carolina poplar. A form of this species, planted at Sault Ste. Marie, but not noticed as spreading. 
MYRICACEAE. Sweet Gale Family

Myrica gale I. Sweet gale. Wet places, borders of ponds, and in swamps throughout. Very abundant at Whitefish Point and Vermilion.

Myrica asplenfolia I. Sweet fern. Open or slightly shaded dry sandy ground throughout. Often abundant.

\section{BETULACEAE. Birch Family}

Corylus rostrala Ait. Beaked hazelnut. Dry open ground throughout. Frequent and in spots abundant.

Ostrya virginiana (Mill) K. Koch. Ironwood. Noticed as frequent in rich ground with other trees from Pickford to Detour. Reported as frequent along the Tahquamenon River back of Emerson, but not seen by the writer.

Betula lutea Michx.f. Yellow birch. In rich ground with sugar maple and beech forming large forests yet standing. Trees often large. Land cruisers and lumbermen call the small smooth-barked trees "yellow birch" and the large ones with shaggy bark, "red birch".

Betula alba papyrifera (Marsh) Spach. White birch. Canoe birch. With other trees throughout. Seldom abundant.

Betula pumila glandulifera Michx. Glandular low birch. Borders and in open places of tamarack-black spruce swamps throughout. Abundant.

Alnus incana (L.) Moench. Speckled alder. Swamps and borders of streams throughout. Abundant along Shelldrake River, covering the river bottom forming an excellent day shelter for deer.

FAGACEAE. Beech Family

Fagus grandifolia Ehrh. Beech. In rich ground with other trees forming large forests throughout.

Quercus macrocarpa Michx. Bur oak. Noticed only in rich ground with other trees from Brimley to Detour. Trees often very large and tall. Reported as formerly plentiful in eastern half of Chippewa County.

Q.bicolor Willd. Swamp white oak. Reported along the Tahquamenon River above the lower falls, but not seen. Since noticed along the river in Luce County. Known to lumbermen generally as "hiluc oak".

Quercus rubra. I. Red oak. More or less throughout. Frequent on sand ridges; plentiful on sand dunes and in sandy ground along Lake Superior shore from Shelldrake to Vermilion. Common on sandy gromel up the Tahquamenon River back of Limerson. Trees usually small, large ones having been cut. Staminate flowers abundant June $1 \%$, $191 \%$. 


\section{URTICACEAE. Nettle Family}

L'7mus americana I. American elm. Frequent throughout, especially along streams. Often with beech and maple, and many trees large.

I'rtica gracilis Ait. Slender nettle. Occasional throughout in moist open or slightly shaded ground.

\section{SANTALACEAE. Sandalwood Family}

Comandra richardsiana Fernald. Richards' toadflax. Dry sandy ground throughout. Often abunciant.

Comandra livida Richards. Northern comandra. In dry sandy ground near Vermilion. Apparently infrequent. Probably overlooked.

\section{POLYGONACEAE. Buckwheat Family}

Rumex britannica L. Great water dock. Wet swampy mositly open places throughout. Common near Vermilion on border of tamarackblack spruce swamps.

Rumex crispus L. Yellow dock. In cultivated and waste grounds throughout. Common.

Rumex obtusifolius L. Bitter dock. As a weed in cultivated grounds. Infrequent.

Rumex aretosella $\mathrm{L}$. Field sorrel. Frequent as a weed near dweliings and cultivated grounds.

Polygonum aviculare L. Knot-grass. About dwellings and in cultivated grounds as a weed. Frequent.

Polygonum erectum L. Erect knotweed. Only as a weed in waste places, cultivated grourds and about dwellings. Not common.

Polygonum ramosissimum Michx. Bushy knotweed. Abundant in a clearing north of Eckerman, appearing to be introduced.

Polygonum lapathifolium L. Pale persicaria. Occasional about farm buildings and in cultivated grounds, appearing to be introduced.

Polygonum amphibium L. Water persicaria. Along streams and ponds throughout. Plentiful.

Polygonum hydropiper L. Common smartweed. Damp open or slightly shaded ground throughout. Often plentiful.

Polygonum persicaria I. Lady's thumb. Occasional as a weed about farm buildings and in cultivated grounds.

Polygonum segittatum L. Arrow-leaved tear-thumb. Damp or swampy places, open or slightly shaded throughout. Frequent.

Polygonum convolvulus L. Black bindweed. As a weed in gardens and cultivated grounds. Not abundant.

Polygonum cilinode Michx. Fringed black bindweed. Open dryish or damp ground throughout. Abundant in spots. 
Polygonella articulata (L.) Meisn. Coast jointweed. In sandly open ground throughout. Often abundant.

\section{CHENOPODIACEAE. Goosefoot Family}

Chenpodium capitatum (L.) Asch. Strawberry blite. Open ground near Eckerman. Apparently infrequent.

Chenopodium album L. Lamb's quarters. Pigweed. Only as a weed in cultivated grounds and apparently not abundant.

Atriplex patula hastata (L.) Gray. Halbard-leaved orache. Occasional as a weed about farm buildings and in streets of villages.

Atriplex patula littoralis (L.) Gray. Shore orache. Streets of Dotour. Apparently infrequent.

Salsola kali tenuifolia G. F. W. Mey. Russian thistle. Occasional about farm buildings in and about Sault Ste. Marie.

AMARANTHACEAE. Amaranth Family

Amaranthus retroflexis L. Amaranth pigweed. In cultivated and waste grounds throughout but seldom abundant.

A maranthus graecizans L. Tumbleweed. In cultirated grounds. Not abundant.

Amaranthus blitoides Wats. Prostrate amaranth. Only as a weed about villages and not abundant.

\section{PHYTOLACCACEAE. Pokeweed Family}

Phytolacca decandra L. Pokeweed. Pigeon berry. Noticed by T. L. Hankinson, ichthyologist, near Vermilion. Very probably an escape from cultivation.

\section{CARYOPHYLLACEAE. Pink Family}

Spergula arvensis L. Corn spurrey. Along roads and in clearings north of Eckerman. Plentifu?.

Stellaria borealis Bigel. Northern stitehwort. Open damp places in tamarack-black spruce swamps near Vermilion. Abundant.

Stellaria longi folia Muhl. Long-leaved stitehwort. Damp open places throughout. Frequent.

Stellaria media (L.) Cyrill. Common chickweed. A weed in waste places and cultivated grounds but seldom abundant.

Cerastium vulgatum L. Common mouse-ear chickweed. In cultirated grounds but seldom abundant.

Lychnis alba Mill. White campion. Occasional about farm buildings and in waste places as a weed. 


\section{PORTULACACEAE. Purslane Family}

Claytonia caroliniana Michx. Carolina spring beauty. Beech-maplebirch woods throughout. Common.

Portulaca oleracea I. Common purslane. A weed in gardens but apparently not abundant.

\section{NYMPHAEACEAE. Water Lily Family}

Nymphaea advena Ait. Yellow pond lily. In ponds, small lakes, and slow streams throughout. Common.

Nymphaea adiena vuriegata (Engelm) Fernald. Variegated yellow pond lily. Noticed near the lower falls of the Tahquamenon River above Emerson.

Castalia tuberosa (Paine) Green. Tuberous white water lily. In open ponds and small lakes throughout. Frequent.

Brasenia schreberi Gmel. Water shield. In ponds, small !akes, and slow streams. Plentiful.

\section{RANUNCULACEAE Crowfoot Family}

Ranunculus purshii Richards. P'ursh's buttercup. Abundant along a slow stream in tamarack-black spruce swamp near Vermilion. Not noticed elsewhere.

Ranunculus abortivus L. Small-fowered crowfoot. In beech-maplebirch woods and other damp shaded places throughout. Frequent.

Ranunculus recurvatus Poir. Hooked crowfoot. Beech-maple-birch woods throughout. Irequent.

Ranunculus septentrionalis Poir. Swamip buttercup. Moist open or shaded places throughout. Frequent.

Ranunculus pennsylvanicus L.f. Bristly crowfoot. Wet open places. Apparently rare.

Ranunculus acris I. Tall crowfoot. Established throughout, appearing like a native plant, but nowhere abundant.

Thalictrum dasycarpum Fisch. and Lall. Purplish meadow rue. Rich ground on borkers of woods, along streams and in thickets. Frequent throughout.

Hepatica acutiloba DC. Sharp-lobed liver leaf. Hardwoods. Frequent.

Anemone canadensis L. Canada anemone. Damp open ground throughout. Frequent.

C'lematis virginiana L. Virginia virgin's bower. Along small streams. Frequent throughout.

Caltha palustris L. Marsh marigold. Wet open shaded ground throughout. Frequent. 
Coptis trifolia (L.) Salisb. Goldthread. Damp open or shaded ground throughout. Common.

Actaea rubra (Ait.) Willd. Red baneberry. In woods throughout. Frequent.

Actaea alba (L.) Mill. White baneberry. Beech-maple-birch woods throughout. Frequent.

FUMARIACEAE. Fumitory Family

Dicentra.cucullaria (L.) Bernh. Dutchman's breeches. Beech-maplebirch woods near Eckerman. Apparently infrequent.

\section{CRUCIFERAE. Mustard Family}

Alyssum alyssoides L. Yellow alyssum. In and about Sault ste. Marie as a weed. Frequent.

Lepidium virginicum $\mathrm{L}$. Wild pepper-grass. In and about Sault Ste. Marie as a weed, and in cultivated grounds.

Capsella bursa-pastoris (L.) Medic. Shepherd's purse. As a weed in cultivated grounds, but not abundant.

Cakile edentula (Sigel.) Hook. American sea rocket. Beach of Lake Superior. Seldom abundant.

Brassica arvensis (L.) Ktze. Common mustard. A weed in cultivated grounds but apparently infrequent.

Sisymbrium officinale leiocarpum DC. Smooth-podded hedge mustard. Occasional as a weed about dwellings and in villages.

Sisymbrium altissimum L. Tumble mustard. Near Trout Iake as a weed. Infrequent.

Erysimum cheiranthoides L. Worm-seed mustard. In cultivated grounds but not abundant.

Radicula nasturtium-aquaticum (I.) Britten \& Rendle. True water cress. Occasional throughout in small creeks and ditches.

Radicula palustris (L.) Moench. Marsh cress. Wet open or slightly shaded places throughout. Not common.

Barbarea vulgaris R.Br. Common winter cress. Oceasional throughout in low ground.

Cardamine pratensis I. Cuckoo flower. Border of small slow-running creek in tamarack-black spruce swamp near Termilion. Apparently infrequent.

Cardamine pennsylvanica. Muhl. Pennsylvania hitter eress. Ilong a slow running creek in a tamarack-black spruce swamp near lemilion. Apparently rare.

Arabis lyrata L. Lyre-leaved rock cres.. Sandy shores of I.ake Superior at Whitefish Point, but not abundant. 
SARRACENIACEAE. Pitcher-plant Family

Sarracenia purpurea I. Pitcher-plant. Bogs and swamps throughout. Frequent.

DROSERACEAE. Sundew Family

Drosera rotundifolia L. Round-leaved sundew. In bogs and swamps throughout. Often abundant.

Drosera longifolia L. Oblong-leaved sundew. Bogs and wet sandy shores. Apparently infrequent.

CRASSUlaCEAE. Orpine Family

S'edum acre L. Mossy stone crop. Noticed on sandy ground in and about Sault Ste Marie.

Sedum purpureum Tausch. Live-for-ever. Noticed as an escape in and about Sault Ste. Marie.

\section{SAXIFRAGACEAE. Saxifrage Family}

Tiarella cordifolia L. Beech-maple-birch woods throughout. Frequent.

Mitella nuda L. Naked bishop's cap. Woods, especially tamarackblack spruce swamps throughout. Common.

Chrysosplenium americana Schwein. Golden saxifrage. Wet shaded places especially along small slow streams. Common throughout.

Parnassia caroliniana Michx. Carolina grass-of-parnassus. Swampy open or slightly shaded places throughout. Frequent.

Ribes floridum L'Hér. Wild black currant. Damp shaded ground throughout. Frequent.

Ribes lacustre (Pers.) Poir. Swamp black currant. Woods throughout and frequent.

Ribes prostratum L'Her. Skunk currant. Beech-maple-birch woods throughout. Frequent.

\section{ROSACEAE. Rose Family}

Physocarpus opuifolius (L.) Maxim. Ninebark. Along banks of streams throughout. Common.

Spiraea salicifolia L. Meadow-sweet. Low damp open grounả, often in damp sand, throughout. Common.

Pyrus malus L. Apple. Along roads and margins of woods throughout. Frequent.

Pyrus arbutifolia atropurpurea (Britton) Robinson. Purple-fruited chokeberry. Damp open or slightly shaded swampy places. Common throughout. Occasional on sand dunes. 
Pyrus americana (Marsh.) DC. American mountain ash. Woods everywhere. Common. Often 40 feet high. Prof. C. S. Sargent says in this region the mountain ashes come close to what he calls Sorbus americana decora Sarg. See Manual of the Trees of North America, C. S. Sargent, page 357 .

Amelanchier laevis Wiegand. Smooth-leaved juneberry. In dryish open or shaded ground throughout. Frequent. Rhodora Vol. 14-1.54. No. 163, July 1912.

Amelanchier bartramiana (Tausch) Roemer. Bartram's juneberry. Borders of woods throughout. Common. Rhodora Vol. 14-158, No. 163. July 1912.

Amelinchier bartramiana laevis. Common throughout. Hybrids seem to prevail in Chippewa County.

Crataegus rotundifolia Moench. Round-leaved thorn. Common along the Tahquamenon River near Emerson.

Crataegus douglasii Lindl. Douglas' thorn. (C. brockwayge Sarg.). At Emerson and Vermilion in sandy open or slightly shaded ground. Not frequent.

Fragaria virginiana Duchesne. Common strawberry. Dryish open or slightly shaded ground throughout. Common.

Fragaria virginiana glauca Wats. Glaucous western strawberry. Dry open ground near Vermilion. Frequent.

Fragaria vesca americana Porter. American wood strawberry. Woods and often in tamarack-black spruce swamps. Frequent throughout.

Potentilla monspeliensis L. Rough cinquefoil. Open sandy ground throughout. Common.

Potentilla palustris (L.) Scop. Marsh five finger. Open wet hoggy places throughout. Common.

Potentilla fruticosa L. Shrubby cinquefoil. Damp open ground throughout. Plentiful near Eckerman.

Polentilla tridentata Ait. Three-toothed cinquefoil. Damp or dry open ground throughout. Often abundant in spots.

Potentilla canadensis L. Common cinquefoil. Open dry sandy ground throughout. Not common.

Geum canadense Jacq. White avens. Woods throughout. Plentiful.

Geum strictum Ait. Yellow avens. Moist open ground throughout. Frequent.

Geum rivale L. Water avens. Wet open or slightly shaded places throughout.

Rubus idaeus aculeatissimus (C. A. Mey.) Regel of Tiling. Wild red raspberry. Dryish open or slightly shaded ground throughout. C'ommon.

Rubus triforus Richards. Dwarf raspberry. Wet shaded places throughout. Common. 
Rubus allegheniensis Porter. Tail blackberry. Dry open or slightly shaded ground throughout. Frequent.

Rubus nigricans Rydb. Bristly blackberry. About dead tamaracks in margin of tamarack-black spruce swamp near Emerson. Plentiful at this place.

Rubus hispidus L. Hispid blackberry. Damp open or slightly shaded ground throughout. Frequent.

Rubus villosus Ait. Dewberry. Dry sandy ground, often on shaded sand dunes throughout. Frequent.

Agrimonia gryposepala Wallr. Tall hairy agrimony. Dryish open or slightly shaded ground throughout. Frequent.

Rosa acicularis Lindl. Prickly rose. Dryish open or slightly shaded ground throughout. Not còmmon.

Rosa blanda Ait. Meadow rose. Open sandy ground and on sandy beaches. Plentiful.

Rosa rubiginosa L. Sweetbriar. In villages and along roads. Noticed in particular on the road from Sault Ste. Marie to Detour. On Mackinac Island, Mackinac County, and in Chippewa County, Michigan, this shrub is being killed to the ground by the sting of the gall fly, Rhodistes rosae. The shaggy galls formed are often called "rose apples".

Rosa carolina L. Swamp rose. Borders of swamps and streams. Frequent. Noticed in particular along Shelldrake River south of Vermilion.

Prunus virginiana I. Choke cherry. Open ground throughout. Common.

Prunus pennsylvanica L.f. Wild red cherry. Common throughout. Abundant on lumbered over and burned over sand ridges, and in sandy ground of recent clearings.

Prunus pumila L. Sand cherry. Common throughout. Abundant in sandy ground near Lake Superior shore.

Prunus nigra Ait. Canada plum. Abundant along streams near Pickford, and common about Gatesville.

\section{LEGUMINOSAE. Pulse Family}

Trifolium pratense L. Red clover. Frequent everywhere as an escape. Trifolium repens L. White clover. Frequent as a weed everywhere, and abunclant in clearings.

Trifolium hybridum L. Alsike clover. Frequent along roads as an escape.

Melilotus alba Desr. White sweet clover. Occasional in and about Sault Ste. Marie.

Lathyrus maritimus (L.) Bigel. Beach pea. Along the sandy beach of Lake Superior. Abundant in spots, acting as an efficient sand binder. 
Lathyrus palustris L. Marsh vetchling. Moist open ground throughout. Frequent.

Lathyrus palustris linearifolius Ser. Winged marsh vetchling. Damp places and margins of woods throughout. Common.

\section{OXALIDACEAE. Wood Sorrel Family}

Oxalis acetosella L. Common wood sorrel. Beech-maple-birch wroods throughout, often carpeting the ground and old logs. Noticed also in very wet ground under speckled alders along Shelldrake river south of Vermilion.

POLYGALACEAE. Milkwort Family

Polygala paucifolia Willd. Fringed polygala. Dry shaded sandy groind throughout. Often abundant.

\section{ANACARDIACEAE. Cashew Family}

Rhus glabra L. Smooth sumach. Noticed as occasional from Gatesville to Detour.

\section{AQUIFOLIACEAE. Holly Family}

Ilex verticillata (L.) Gray. Winterberry. Low open or slightly shaded ground. Frequent throughout.

Nemopanthus mucronata (L.) Trel. Mountain holly. On margins of and in tamarack-black spruce swamps throughout. Otten plentiful.

\section{ACERACEAE. Maple Family}

Acer pennsylvanicum L. Striped maple. Noticed as frequent from Gatesville to Detour.

Acer spicatum Lam. Mountain maple. Damp woods and thickets throughout. Abundant.

Acer saccharum Marsh. Sugar maple. With beech, birch, some basswood, and hemlock, forming extensive forests still standing throughout the county, excepting in the eastern and southeastern portion where more lumbering has been done. Forests called hardwoods.

Acer rubrum L. Ped maple. A few large trees noticed in rich ground with other trees. Usually in Chippewa County, it is a small seraggy tree covering sandy level ground, sand ridges and sand dunes. Apparently it is the smalier trees that bear fruit.

Acer negundo L. Box elder. Occasionally planted from Sault Ste. Marie to Detour but not noticed as spreading. 


\section{BALSAMINACEAE. Touch-me-not Family}

Impatiens biflora Walt. Spotted touch-me-not. Moist open or shaded ground throughout. Abundant.

\section{RHAMNACEAE. Buckthorn Family}

Rhamnus alnifolia L'Her. Alder-leaved buckthorn. Open damp or slightly shaded ground throughout. Often plentiful.

\section{TILIACEAE. Linden Family}

Titia americana L. Basswood. Often with beech, birch. and maple. Trees sometimes large. Frequent throughout.

\section{MALVACEAE. Mallow Family}

Malia rotundifolia.L. Common mallow. A weed about dwellings and in villages. Not abundant.

Malva moschata L. Musk mallow. In fields and along roads about Brimley, Sault Ste. Marie, and south to Detour.

\section{HYPERICACEAE. St. John's-wort Family}

Hypericum perforatum L. Common St. John's-wort. An occasional weed on farms and in villages.

Hypericum punctatum Lam. Spotted St. John's-wort. In woods and thickets near Brimley. Not noticed elsewhere.

Hypericum kalmianum L. Kalm's St. John's-wort. Sandy open ground, usually near shores. Frequerit.

Hypericum ellipticum Hook. Pale St. John's-wort. Abundant along Shelldrake River south of Vermilion. Noticed throughout.

Hypericum, boreale (Britton) Bicknell. Northern St. John's-wort. Wet open places throughout. Abundant near Vermilion.

Hypericum majus (Gray) Britton. Large Canadian St. John's-wort. Damp sand near lighthouse at Whitefish Point. Plentiful at this place.

Hypericum canadense L. Canadian St. John's-wort. In damp open sandy ground near Eckerman. Plentiful at this place.

Hypericum virginicum I. Marsh St. John's-wort. Open wet and swampy ground throughout. Frequent.

\section{CISTACEAE. Rockrose Family}

Helianthemum canadense (L.?) Michx. Long-branched frostweed. Sandy open ground throughout. Plentiful.

Hudsonia tomentosa intermedia Peck. Awl-leaved hudsonia. Common on the sandy beach of Lake Superior and on sand dunes at Whitefish Point and Termilion. 
VIOLACEAE. Violet Family

Viola cucullata Ait. Marsh blue violet. Wet open or slightly shaded places throughout. Frequent.

Viola sororia Willd. Wooly blue violet. Rich open or shaded places throughout. Plentiful.

Viola lanceolata I. Lance-leaved violet. Damp open ground throughout. Often abundant.

Viola pallens (Banks) Brainard. Northern white violet. Wet springy places and along small creeks throughout. Common.

Viola incognita Brainard. Large-leaved white violet. Woods throughout. Common.

Viola renifolia Gray. Kidney-leaved violet. Rich woods throughout. Aluundant.

Viola scabriuscula Schwein. Smoothish yellow violet. Damp rich shaded ground throughout. Frequent.

Viola conspersa Reichenb. American dog violet. Rich damp open shaded ground throughout. Plentiful.

ONAGRACEAE. Evening Primrose Family

Epilobium angustifolium L. Great willow-herb. Fireweed. Damp or dry ground throughout, especially in clearings and burned-over-ground. Often abundant.

Epilobium adenocaulon Haussk. Northern willow-herb. Rich damp or slightly shaded ground throughout. Common.

Oenothera biennis L. Common evening primrose. Open sandy ground throughout. Infrequent.

Circaea lutetiana L. Enchanter's nightshade. In woods throughout. Noticed in particular near lower falls of Tahquamenon River above Emerson.

Circaea alpina L. Smaller enchanter's nightshade. In damp rich woods throughout. Often abundant.

\section{ARALIACEAE. Ginseng Family}

Aralia racemosa L. Spikenard. Rich woods throughout. Not common.

Aralia hispida Vent. Bristly sarsaparilla. Usually in dry sandy open ground throughout. Abundant on recently burned orer sandy land, sand ridges, and in clearings.

Aralia nudicaulis L. Wild sarsaparilla. Moist woods throughout. and abundant. Often plentiful on dry shaded ground and eren on shaded sand dunes. 


\section{UMBELLIFERAE. Parsley Family}

Osmorhiza longistylis (Torr.) DC. Smoother sweet cicely. Rich woods throughout. Common.

Osmorhiza divaricata Nutt. Western sweet cicely. Beech-maplebirch woods throughout. Frequent.

Cicuta bulbifera L. Bulb-bearing water hemlock. Wet open ground throughout. Common.

Carum carvi L. Caraway. Occasional throughout near farm buildings and in villages.

Heracleum lanatum Michx. Abundant near Emerson in one place. Not noticed elsewhere.

\section{CORNACEAE. Dogwood Family}

Cornus canadensis L. Dwarf cornel. In woods and thickets throughout. Often carpeting the ground.

C'ornus circinate L'Her. Round-leaved cornel. Usually in sandy open ground, or bordering woods and thickets. Common throughout.

Cornus stolonifera Michx. Red-osier dogwood. Usually in damp ground, sometimes in sand, throughout. Not common.

Cornus alternifolia L.f. Alternate-leaved cornel. Borders of streams and woods. Frequent.

\section{ERICACEAE. Heath Family}

Chimaphila umbellata (L.) Nutt. Prince's pine. Dry shaded ground, usually among pines. Frequent throughout.

Moneses uniflora (L.) Gray. One-leaver pyrola. Beech-maple-birch woods near Termilion. Apparently infrequent but perhaps overlooked. N. A. Wood.

Pyrola chlorantha Sw. Greenish-flowered wintergreen. Beech-maplebirch woods throughout. Frequent.

Pyrola secunda L. One-sided winter-green. Beech-maple-birch woods throughout. Frequent.

Pyrola secunda obtusata Turcz. Obtuse-leaved pyrola. Tamarackblack spruce swamp near Eckerman. Apparently infrequent.

Monotropa uniflora L. Indian pipe. Usually in rich woods, sometimes in the open. Noticed by N. A. Wood near Vermilion.

Monotropa hypopitys I. Pine sap. Dry sandy shaded ground at Whitefish Point. Apparently rare. Perhaps overlooked.

Ledum groenlandicum Oeder. Labrador tea. Open boggy ground and even on sandy ground and sides of shaded sand dunes throughout. Oneof the most abundant shrubs in the county.

Kalmia polifolia Wang. Pale laurel. In open boggy ground throughout. Common. 
Andromeda glaucophylla Link. Bog rosemary. Open or shacled toggy ground throughout. Common.

Chamaedaphne calyculata (L.) Moench. Leather leaf. Open or slightly shaded boggy ground throughout. Abundant. This and the three preceding are the prominent and dominant bog shrubs of the county.

Epigaea repens L. Trailing arbutus. Sandy open or slightly sharled ground throughout. Common and in spots abundant.

Gaultheria procumbens L. Wintergreen. Usually in open or slightly shaded ground, sometimes in tamarack-black spruce swamps in sphagnum. Abundant throughout. Fruit abundant and delicious. June 18, 1914.

Arctostaphylos uva-ursi (L.) Spreng. Bearberry. Sandy beach of Lake Superior, and on sand dunes throughout. Plentiful near Whitefish Point and Vermilion.

Chiogenes hispidula (L.) T. \& G. Creeping snowberry. Open or slightly shaded boggy ground throughout. Often abundant in tamarackblack spruce swamps.

Gaylussacia baccata (Wang.) C. Koch. Black huckleberry. Open or slightly shaded sandy ground sometimes in swamps, throughout. Frequent. Fruit black and collected for domestic use and occasionally for market.

Taccinium pennsylvanicum Lam. Low sweet blueberry. Open or slightly shaded sandy ground, sometimes in swamps, throughout. Tery abundant. Berries delicious, gathered for market and domestic use.

Vaccinium pennsylvanicum nigrum IVood. Low black blueberry. Oceasional throughout in same habitat as preceding. Fruit black, ripe at the same time as the preceding, and collected with it for market and domestic use.

Vaccinium canadense Kalm. Sour top. Dry sandy open ground or in swamps throughout. Abundant. Berries blue and gathered for markit and sold as "blueberries", with the preceding species and varicty. Fruit slightly tart, abundant and delicious September 3, 1914, but not considered quite so choice as the low sweet blueberry.

Vaccinium membranaceum Doug]. Thin-leaved bilberry. ['sually in rich shaded ground, sometimes in damp sand. Common throughout, Called "rabbit berry" in Chippewa County. Fruit large, usually black, rather tart, but delicious and gathered for domestic use, ripe septemher 3, 1914. Berries too tender and delicate for market purposes. Perhaps a shrub worth trial and experiment in cultivation.

Vaccinium ovalifolium Sm. Oval-leaved bilberry. Usually in rich shaded ground throughout often growing with the preceding. Ahundant. Berry blue, large, but smaller than that of the preeceding, slightly tart, but delicious and much sought after for domestie use, although too 
delicate and tender for market, ripe September 3, 1914. Known in Chippewa County as "myrtilloid berry", or "myrtilloid huckleberry". Perhaps this shrub also is worth some attention.

Vaccinium macrocarpon Ait. American cranberry. Boggy places and swamps throughout. Sometimes abundant. At Vermilion is a model cranberry farm owned and fitted up by the late Mr. John Clark, and another at Whitefish Point owned by Mr. Frank House.

\section{PRIMULACEAE. Primrose Family}

Lysimachia terrestris (i..) BSP. Bulb-kearing loosestrife. Low wet open ground throughout. Frequent.

Lysimachia thyrsiflora L. Tufted loosestrife. Very wet open places and in shallow water throughout. Often abundant.

Trientalis americana (Pers.) Pursh. Star flower. Damp woods and thickets throughout. Common.

\section{OLEACEAE. Olive Family}

Fraxinus nigra Marsh. Black ash. In swampy ground with other trees throughout. Disappearing in many parts of the county on account of forest fires. Abundant along the Tahquamenon River above Emerson.

\section{GENTIANACEAE. Gentian Family}

Halenia deflexa (Sm) Griseb. Spurred gentian. Common in damp shaded ground throughout, especially in hardwood.

Menyanthes trifoliata L. Buckbean. Abundant throughout in boggy places and shallow water.

APOCYNACEAE. Dogbane Family

Apocynum androsaemifolium L. Spreading dogbane. In open dry ground throughout. Frequent.

\section{BORAGINACEAE. Borage Family}

Cynoglossum officinale L. Common hound's tongue. Occasional about farm buildings. Apparently rare in other places.

Lappula echinata Gilibert. European stickweed. Along roads and in villages. Infrequent.

\section{LABIATAE. Mint Family}

Scutellaria lateriflora L. Mad-dog skullcap. Rich shaded ground near lower falls of Tahquamenon River above Emerson. Apparently infrequent. 
Scutellaria galericulata L. Marsh skulleap. Wet marshy ground near Emerson. Apparently infrequent.

Nepeta cataria L. Catnip. In villages but not abundant.

Nepeta hederacea (L.) Trevisan. Ground ivy. In damp shaded gromnd. Infrequent.

Prunella vulgaris L. Heal-all. Noticed at Emerson. Apparently rare.

Galeopsis tetrahit L. Common hemp nettle. Along roads throughout. Often abundant.

Blephitia hirsuta (Pursh) Benth. Hairy blephilia. Beech-maplebirch woods near the lower falls of the Tahquamenon River above Emerson. Apparently infrequent.

Satureja vulgaris (L.) Fritsch. Basil. Dryish open ground or in rlry open woods and thickets throughout. Frequent.

Lycopus uniflorus Michx. Bugle weed. Low open or slightly shaded ground throughout. Frequent.

Lycopus americanus Michx. Cut-leaved water hoarhound. I)amp open or slightly shaded ground throughout. Common.

Mentha spicata I. Spearmint. At Trout Lake. Apparently rare.

Mentha citrata Ehrh. Bergamot mint. Rare as an escape from cultivation. Noticed south of Sault Ste. Marie.

Mentha arvensis canadensis (L.) Briquet. American wild mint. Rich damp open or slightly shaded ground throughout. Frequent.

\section{SOLANACEAE. Nightshade Family}

Physalis heterophylla Nees. Clammy ground cherry. Foot of a sand dune at Vermilion, a large bunch of it. Not noticed elsewhere.

\section{SCROPHULARIACEAE. Figwort Family}

Verbascum thapsus I.. Common mullein. Along roads and in ficlds throughout. Not noticed as abundant anywhere.

Linaria vulgaris Hill. Butter and eggs. A weed at Trout Ialie. Apparently rare in this county.

Scrophularia leporella I3icknell. Hare figwort. Usually in rich open ground throughout. Frequent.

Chelone glabra L. Balmony. Snakehead. Wot ground, borders of wood and thickets and along small streams. Frequent.

Mimulus ringens L. Square-stemmed monkey flower. Wet places, borders of creeks and in ditches throughout. Frequent.

Veronica americana Sehwein. American brooklime. Brooks, ciitches, and wet places throughout. Frequent.

Melampyrum lineare Lam. Cow wheat. Open woods thrughout. Common. 
LENTIBULARIACEAE. Bladderwort Family

Utricularia intermedia Hayne. Flat-leaved bladderwort. Very wet places and shallow water throughout. Often abundant.

Ctricularia cornuta Nichx. Horned bladderwort. Wet sandy open ground throughout. Frequent.

OROBANCHACEAE. Broom-rape Family

Epifagus virginiana (L.) Bart. Beech-drops. Under beeches throughout. Common.

PLANTAGINACEAE. Plantain Family

Plantago major L. Common plantain. About farm buildings and in villages but not abundant.

Plantago rugelii Dene. Pugel's plantain. Along roads and in fields and clearings throughout. Frequent.

\section{RUBIACEAE. Madder Family}

Galium trifidum L. Small bedstraw. Open or slightly shaded wet and swampy places throughout. Frequent.

Galium claytoni Michx. Clayton's bedstraw. Damp places and swamps throughout. Frequent.

Galium asprellum Michx. Rough bedstraw. Damp open or slightly shaded places throughout, usually climbing over small shrubs or other plants. Common.

Galium triflorum Michx. Sweet scented bedstraw. Rich thin woods throughout. Common.

Mitchella repens L. Partridge berry. Dry woods throughout. Common.

\section{CAPRIFOLIACEAE. Honeysuckle Family}

Diervilla lonicera Mill. Bush honeysuckle. Open or slightly shaded dry and sandy ground throughout. Common.

Lonicera canadensis Marsh. American fly honeysuckle. Open woods and margins of thickets throughout. Common.

Lnnicera oblongifolia (Goldie) Hook. Swamp fly honeysuckle. Tamarack-black spruce swamps throughout. Frequent.

Lonicera hirsuta Eat. Hairy honeysuckle. Margins of woods near Eckerman. Apparently infrequent. A vine.

Lonicera dioica L. Glaucous honeysuckle. Margins of woods and thickets throughout but not common. A vine.

Syn pl.oricarpos racemosu.s Michx. Snowberry. Dry open or slightly shaded places throughout. Frequent. 
Linnaea borealis americana (Forbes) Rehder. Twin-flower. Open woods throughout. Often abundant.

Viburnum acerifolium L. Arrow-wood. Dryish open woods throughout. Frequent.

Viburnum cassinoides L. Withe-rod. Wet open or slightly shaded ground throughout. Common.

Tiburnum lentago L. Nannyberry. Margins of woods and along streams throughout. Frequent.

Sambucus canadensis L. Common elder. Open rich ground throughout. Often plentiful.

Sambucus racemosus L. Red-berried elder. Rich open or shaded ground throughout. Common.

\section{VALERIANACEAE. Valerian Family}

Valeriana uliginosa (T. \& G.) Rydb. Swamp valerian. Open wet places, and on margins of tamarack-black spruce swamps. Abundant about a swamp near Eckerman.

\section{CAMPANULACEAE. Bluebell Family}

Campanula rotundifolia L. Harebell. Mostly on sandy beaches. Frequent throughout.

Campanula aparinoides Pursh. Marsh bellflower. Open wet grassy ground throughout. Frequent.

\section{LOBELIACEAE. Lobelia Family}

Lobelia kalmii L. Brook lobelia. Marshy open places throughout. Noticed in particular in swampy ground on margin of tamarack-black spruce swamp north of Eckerman.

\section{COMPOSITAE. Composite Family}

Eupatorium purpureum I. . Joe-pye weed. Low damp open ground and margins of woods throughout. Common.

Eupatorium purpureum maculatum (L.) Darl. Spotted joe-pye weed. IVet open places throughout. Common.

Eupatorium perfoliatum L. Boneset. Iow open or slightly shaded ground throughout. Common.

Solidago hispida Muhl. Hairy goldenrod. Dry open or slightly shaded ground throughout. Common.

Solidago randii (Porter) Britton. Rand's goldenrod. Mostly along or near the sandy beach of Lake Superior. Noticed in particular near Whitefish Point and Vermilion.

Solidago uliginosa Nutt. Bog goldenrod. Open wet and boggy ground throughout. Common. 
Solidago juncea Ait. Early goldenrod. Dry open or slightly shaded ground throughout. Common.

Solidago rugosa Mill. Wrinkled-leaved goldenrod. Damp open or dryish slightly shaded ground throughout. Frequent.

Solidago nemoralis Ait. Gray goldenrod. Dry open ground throughout. Common and often abundant.

Solidago canadensis 1. Canada goldenrod. Borders of woods and in rich open or slightly shaded ground throughout. Common.

Solidago altissima L. Tall goldenrod. Rich open ground throughout. Frequent.

Solidago serotina Ait. Late goldenrod. Rich open or slightly shaded ground throughout. Trequent.

Solidago graminifolia (L.) Salisb. Flat-topped goldenrod. Moist open ground throughout. Common.

Solidago tenuifolia Pursh. Slender fragrant goldenrod. Damp sandy ground near Whitefish Point. Apparently rare.

Aster macrophyllus $\mathrm{I}_{\text {. }}$ Large-leaved aster. Along a shaded high creek bank near Brimley. Plentiful at this place. Apparently rare in Chippewa County.

Aster azureus Lindl. Sky-blue aster. Dry open or shaded ground throughout. Frequent.

Aster lindleyanus T. \& G. Lindley's aster. Damp or dryish open or slihgtly shaded ground throughout. Frequent.

Aster lateriflorus (L.) Britton. Calico aster. Open ground near lower falls of the Tahquamenon River above Emerson. Apnarently infrequent.

Aster tradescanti L. Tradescant's aster. Low open ground throughout. Often abundant.

Aster paniculatus Lam. Panicled aster. Wet open ground throughout. Frequent.

Aster junceus Ait. Rush aster. Wet open mearlow-like ground throughout. Frequent.

Aster longifolius Lam. Long-leaved aster. Low open ground throughout. Frequent.

Aster novi-belgii L. New York àster. Damp ground north of Eckerman. Plentiful there. Not noticed elsewhere.

Aster puriceus L. Red-stalked aster. Low swampy ground throughout. Plentiful.

Aster umbellatus Mill. Flat-top white aster. Usually in moist shaded ground. Abundant throughout.

Aster nemoralis Ait. Bog aster. Very wet boggy open ground throughout. Abundant near Emerson.

Erigeron philadelphicus I. Philadelphia fleabane. Occasional as a weed and appearing to be introduced. 
Erigeron annuus (I.) Pers. Sweet scabious. Apparently as a weed only and probably introduced.

Erigeron ramosus (Walt.) BSP. Daisy fleabane. Noticed only ats a weed and probably introduced.

Erigeron canadensis L. Horse weed. In cultivated grounds as a weed. Not abundant.

Antennaria neodioica Greene. Smaller cat's-foot. Open woods throughout. Frequent.

Antennaria petaloidea Fermald. Common cat's foot. Dry open ground, sand dunes and fixed ridges, throughout. Common.

Anaphalis margaritacea (I.) B. \& H. Pearly everlasting. Dry open or slightly shaded ground throughout. Common.

Gnaphalium decurrens Ives. Clammy everlasting. Dry open ground throughout, but infrequent.

Gnaphalium uliginosum L. Low eudweed. Noticed along roads at Brimley and other villages. Not common.

Inula helenium L. Elecampane. Along road near Gatesville. Apparently infrequent.

Ambrosia artemisiifolia L. Common ragweed. As a weed only and infrequent.

Rudbeckía hirta I. Yellow daisy. Black-eyed Susan. Dry open ground throughout, but infrequent.

Rudbeckia laciniata L. Tall coneflower. Low thickets and along small creeks throughout. Frequent.

Helianthus giganteus L. Tall sunflower. Low ground near Eckerman. Apparently rare.

Bidens frondosa L. Beggar ticks. Damp open ground but infrequent.

Bidens comosa (Gray) Wiegand. Leafy-bracted ticksced. Damp open ground throughout. Frequent.

Bidens cernua L. Smaller bur-marigold. Damp open ground throughout. Frequent. Abundant near Shelldrake.

Achillea millefolium L. Common yarrow. Roads and ficlds throughout but not abundant.

Anthemis cotula L. May-weed. About farm buildings and in villages. Not abundant.

Chrysanthemum leucanthemum pinnatifidum Lecoq \& Lamotte. Oxeye daisy. Occasional as a weed. Not noticed as abundint anywhere.

Chrysanthemum balsamita tanacetoides Boiss. Costmary. Roadside near Gatesville. Apparently infrequent as an escape.

Tanacetum huronense Nutt. Lake Huron tansy. On or near the sandy beach of Lake Superior. Abundant in spots.

Artemisia caudata Michx. Tall wormwood. On sandy beach of Lake Superior, sand dunes and fixed sand ridges throughout. Irrequent. 
Artemisia biennis Willd. Biennial wormwood. Along roads and in villages as a weed. Not common.

Artemisia absinthium L. Common wormwood. Occasional throughout. Abundant at Gatesville covering large areas of ground.

Petasites palmatatus (Ait.) Gray. Palmate-leaf sweet coltsfoot. Wet open or shaded ground throughout. Frequent.

Senecio aureus L. Golden ragwort. Wet open or shaded ground throughout. Often abundant.

Senecio balsamitae Muhl. Balsam groundsel. Dry open ground throughout. Not common.

Cirsium lanceolatum (L.) Hill. Common thistle. Occasional throughout as a weed.

Cirsium pitcheri (Torr.) T. \& G. Pitcher's thistle. Sandy beach of Lake Superior, but not abundant.

Cirsium discolor (Muhl.) Spreng. Field thistle. Rich open or slightly shaded ground throughout. Frequent.

Cirsium muticum Michx. Swamp thistle. Wet swampy places throughout. Frequent.

Cirsium arvense (L.) Scop. Canada thistle. Gradually spreading as a weed in cultivated grounds.

Taraxacum officinale Weber. Dandelion. Throughout but nowhere noticed as abundant.

Sonchus oleraceus L. Common saw thistle. As a weed in cultivated grounds, but not common.

Sonchus asper (I.) Hill. Spiny-leaved saw thistle. A weed in cultivated grounds. Infrequent.

Lactuca scariola intergrata Gren. \& Godr. Entire-leaved prickly lettuce. A weed in cultivated grounds, but infrequent.

Lactuca canadensis L. Wild lettuce. Rich damp open or slightly shaded ground throughout. Frequent.

Lactuca spicata (Lam.) Hitchc. Tall blue lettuce. Low open or slightly shaded ground throughout. Common.

Hieracium venosum L. Rattlesnake weed. Dry open or slightly shaded places throughout. Frequent.

Hieracium scabrum Michx. Rough hawkweed. Dry open or slightly shaded ground throughout. Common.

Hieracium canadense Michx. Canada hawkweed. Dry open or slightly shaded ground throughout. 
OBSERVATIONS ON THE ILOWERING PLANTS, FERNA AND FERN ALLIES GROWING WITHOUT CULTIVATION IN TUSCOLA COUNTY, MICHIGAN.

The late Professor C. A. Davis, while engaged in geological work for Tuscola County begun in 1897, made incidental observations on the wild plants, and his report with an annotated list of plants was published in the Tenth Annual Report of the state geologist for the year 1908, page 290, under title "The Native Vegetation of Tuscola County. The Factors Affecting Plant Distribution." This was merely the latter part of his valuable report on "The Geology of Tuscola County, Michigan," published in the same report, page 121. The part of the report on plants was timely and very valuable, for about that time the northern part of the county, where the plant observations were mostly made, was rapidly undergoing a radical change brought about hy drainage and preparation for sugar beet culture. Long before the publication of his ecological observations and plant list, Professor Davis urged the writer to complete, so far as possible, the plant list of the county, make a separate report, incorporating his list or so much of it as should seem best. Accordingly in 1910 the work was taken up as an independent effort and the county investigated as well as might be. The Saginaw Bay shore was traversed and examined from the west line of Huron County to the east line of Bay County, nearly every small lake visited, its shores and adjacent marshes and swamps examined and the morainal hills looked over as carefully as time would permit, not forgetting swamps yet untouched by destructive fires, the marshes and prairie-like land and the so called islands in the northern part. Professor Davis reported 591 species, a remarkably large number considering that this part of his effort was merely incidental to matters considered at the time of far greater economic importance. After much eareful search the number of species noticed did not quite reach 1,000 , but it is believed that from 1,100 to 1,200 species of wild plants still exist within the limits of 'Tuscola County, which will be found and yet recorded if local hotanists make a careful search.

It is not intended or believed that this effort shall or can talic the place of Professor Davis' renort which will ever stand out prominently as a work very clearly and fully representing the surface conditions of the land and ecological relations of plant species at the time. 


\section{Geographical Position}

Tuscola County is bounded on the south by Lapeer and Genesee counties, east by Sanilac County, north by a part of Huron County and Saginaw Bay, west by Bay and Saginaw counties. In general outline it is square, approximately 30 miles on a side and is a part of the tract popularly known as "The Thumb." The south line is about 65 miles north of Detroit and 100 miles from the south State line.

\section{The Present and Past Conditions Contrasted}

At present this county has the appearance of a valuable, progressive and successful agricultural district. The land generally speaking is of good quality and everywhere general thrift and prosperity are indicated. In recent years the sugar beet industry has become prominent and valuable. But it seems only yesterday that it was a wild district mostly covered with dense forests penetrated only by paths and trails and a favorite locality for the Indian. For him it was a paradise, as game and fish were plentiful, and his daily wants were easily procured and satisfied. These conditions had existed for an unknown length of time. However on the advent of the paleface a radical and almost sudden change took place. The white man felled and used up the forests, killed with his deadly weapons and consumed the game, and even reduced the former abundant supply of fish. The Indians of this region are now known only in history. These great changes have taken place perhaps within the memory of many yet living in 1910 .

\section{General Surface}

There is very little rock outcropping in the county and the general surface is indeed very variable. In the northern part near and extending south from the Bay, there is much marsh-like or damp prairie-like ground not very much above the level of Saginaw Bay, formerly covered part of the time with shallow water. Dotted here and there in this low ground are spots called islands, raised a few feet above the general level and covered with trees and shrubbery. As hereafter mentioned this prairie-like land in its drier parts seems to have invited a number of species from prairie habitats farther south and west. Toward the south part of the county is apparently very rough with ridges of morainal formation, and, it is said, rises above the Bay level in places from 200 to 400 feet.

The principal stream having several branches is Cass River with a well defined vallcy running through the county from northeast to southwest. There are perhaps 16 small lakes and ponds, two of the lakes being partly in Iapeer County, a number of them having no names and not usually noted on maps. The largest of these lakes are mostly in the 
south and southeastern part and about or near most of them are tamarack-black spruce swamps, many of them having escaped destructive fires. Among these are Spruce Lake, west of Fostoria; Murphy's Lahe, southwest of Mayville; Cat Lake, north of Mayville; Hays Lake in Dayton Township; Cedar Lake, and Long Lake. Along the Saginaw Bay shore temporary ponds are often formed by wave action and these gradually fill up and become marshes, or wet prairie-like land.

\section{Range of Some Plants Extended}

A few plants, mostly peculiar to prairie-like regions farther wouth and west, have appeared in the northern part of Tuscola County as native or at least long established. Prominent among these are Sitphium terebinthinaceum L., prairie dock; Vernonia illinoensis (Hleason, Drummond's iron-weed; Liatris spicata (L.) Willd., gay feather; Cacalia tuberosa Nutt., tuberous Indian plantain; Lythrum alatum Marsh, wingangled loosestrife; Acerates floridana (Lam.) Hitchc., Florida nilkweed; and Asclepias sullivantii Enge!m, Sullivant's milkweed.

\section{ACKNOWLEDGMents}

The writer is much indebted to Mr. Kenneth K. Mackenzie of New York City for an examination and determination of the sedges and other difficult and doubtful plants and to Prof. A. S. Hitchcock, agrostologist of the United States Department of Agriculture, for a determination of some of the grasses.

\section{Annotated List}

\section{POLYPODIACEAE. Fern Family}

Phegopteris dryopteris (I.) Fee. Oak fern. Rich open dryish woods. Frequent.

Adiontum pedatum L. Maidenhair. Frequent in rich words along streams and about the small lakes.

Pteris aquilina L. Common brake. Common and abundant on dry ground or in swamps.

Asplenium acrostichoides Sw. Silver spleenwort. "Wells and Dayton townships in rich woodlands." C. A. Davis.

Asplenium filix-fernina (L.) Bernh. Lady fern. Very common in low open or shaded ground.

Polystichum acrostichoides (Mich.) Schott. Christmas forn. Its favorite place on bluffy shaded banks of streams. Noticed in particular on the shaded bank of a small stream ruming into Murphy's lake.

Aspidium thelypteris (L.) Sw. Marsh shield-fern. Very abundant on low marshy shaded or open ground, especially about the small lakes. 
Aspidium marginale (L.) Sw. Evergreen wood fern. In damp rich woods apparently preferring bluffy shaded banks of streams. Noticed in particular along a small stream running into Murphy's Lake.

Aspidium goldianum Hook. Goldie's fern. Noticed in particular near Murphy's Lake in rich woods. Not noticed elsewhere.

Aspidium cristatum (L.). Sw. Crested shield-fern. "In rich woods in Aimer Township." C. A. Davis.

Aspidium cristatum clintonianum D. C. Eaton. Clinton's fern. Damp rich woods. Frequent.

Aspidium spinulosum (O. F. Müller) Sw. Spinulosé shield-fern. Common in rich woods.

Aspidium spinulosum intermedium (Muhi.) D. C. Eaton. American shield-fern. Common in damp rich woods, especially near the small lakes.

Cystopteris bulbifera (L.) Bernh. Bulblet cystopteris. Frequent and noticed especially in tamarack swamps near the small lakes and on bluffy shaded banks of streams.

Cystopteris fragitis (L.) Bernh. Brittle fern. Occasional in damp rich woods.

Onoclea sensibilis L. Sensitive fern. Very common in damp open or shaded places.

Onoclea struthopteris (L.) Hoffm. Ostrich fern. Apparently preferring rich shaded ground near streams. Noticed only near Murphy's Lake.

\section{OSMUNDACEAE. Flowering Fern Family}

Osmunda regalis L. Royal fern. Common in swamps and wet woods.

Osmunda claytoniana L. Clayton's fern. Noticed on low ground near Murphy's Lake. Probably frequent throughout.

Osmunda cinnamomea L. Cinnamon fern. Frequent in swamps and damp open woods.

\section{OPHIOGLOSSACEAE. Adder's Tongue Family}

Botrychium obliquum Muhl. Ternate grape fern. In rich woods near Murphy's Lake. Apparently infrequent.

Botrychium virginianum (L.) Sw. Rattlesnake fern. Common in rich woods.

\section{EQUISETACEAE. Horsetail Family}

Equisetum arvense L. Common horsetail. Common in rich or poor ground. Usually very abundant along railway embankments, where the extensive roots tend to bind the embankment together.

Equisetum sylvatium L. Wood horsetail. Common in damp shaded 
places and sometimes in open wet ground. Abundant in the swamps near the small lakes.

Equisetum fluviatile I. Pipes. Swamp horsetail. Common in water and very wet places along slow streams and about the small lakes.

Equisetum hyemale intermedium A. A. Eaton. Scouring rush. Frequent in dry open or shaded ground.

Equisetum variegatum Schleich. Variegated equisetum. Abunrlant on spots in wet sand along the Saginaw Bay shore and in wet place's about the small lakes.

\section{LYCOPODIACEAE. Club Moss Family}

Lycopodium lucidulum Michx. Shining club moss. Occasional in rich damp woors.

Lycopodium clavatum L. Common club moss. Dryish open woods. Frequent.

Lycopodium obscurum dendroideum (Michx.) D. C. Eaton. Ground pine. Apparently preferring open dry woods. Noticed only near Murphy's Lake.

Lycopodium complanatum L. Trailing Christmas-green. Occasional in dry open woods. Noticed in particular near Murphy's Lake.

\section{SELAGINELLACEAE. Selaginella Family}

Selaginella apus (L.) Spring. Creeping selaginella. Common on low grassy ground, especially near the Saginaw Bay shore and about the small lakes. A very pretty mossy-looking plant.

\section{TAXACEAE. Yew Family}

Taxus canadensis Marsh. American yew. Ground hemlock. Probably frequent throughout. Noticed in particular in tamarack swamps near Cat Lake and in rich woods near Murphy's Lake.

\section{PINACEAE. Pine Family}

Pinus strobus L. White pine: Formerly very abundant on sandy ground and dry ridges. It was very abundant about Fostoria and on dry hills about the small lakes. Now (1910) only an occasional large tree and small shrubs left. Stumps still in place and stump fenees give evidence of its former prevalence.

Pinus banksiana Lamb. Jack pine. Occasional along or near Siaginaw Bay shore.

Pinus resinosa Ait. Red pine. Norway pinc. Very scattering along or near Saginaw Bay shore.

Larix laricina (Du Roi) Koch. Tamarack. American larch. Form- 
erly abundant in "tamarack swamps", but now very much less common on account of drainage, fires, and lumbering. Small patches of it are still (1910) noticed throughout the county, especially near the small lakes.

Picea mariana (Mill.) BSP. Black spruce. Occasional in swamps mixed with tamaracks. Noticed in particular about Cat Lake.

Tsuga canadensis (L.) Carr. Hemlock. Noticed in damp rich ground with other trees near the small lakes. "Common along the western part of Koylton Township and eastern part of Wells Township." C. A. Davis.

Thuja occidentalis L. Arbor vitae. White cedar. Common in many places but not large. Noticed in particular in sandy ground along Saginaw Bay shore, ahout swamps and on hillsides, and borders of swamps about small lakes. "Frequent in swamps. In many places in Akron Township appearing as undergrowth in the swampy woods." C. A. Davis.

Juniperus communis L. Common juniper. Occasional in dry open or shaded ground.

Juniperus communis depressa Pursh. Low juniper. Frequent in dryish open rocky ground and near beach of Saginaw Bay.

\section{TYPHACEAE. Cat-tail Family}

Typha latifolia L. Common cat-tail. Abundant in very wet ground and swampy places throughout. "Common in ditches and marshes. A bad weed in the ditches of the western part of the county as it checks the outflow of water and helps silt them up." C. A. Davis.

Typha angustifolia L. Narrow-leaved cat-tail. Noticed in very wet ground near the Saginaw Bay shore, in particular at Quanicassee.

\section{SPARGANIACEAE. Bur-reed Family}

Sparganium eurycarpum Engelm. Broad-fruited bur-reed. Very common on borders of ponds, slow streams and in wet places. "Ditches, very common. Also on borders of millponds at Vassar and Caro and in bayous of Cass River. At mouth of Quanicassee Creek." C. A. Davis.

Sparganium simplex Huds. Simple-stemmed bur-reed. "Ditches on west side of county." C. A. Davis.

\section{NAJADACEAE. Pondweed Family}

Potamogeton natans L. Common floating pondweed. Noticed in ponds and on borders of small lakes.

Potamogeton epihydrus Raf. Nuttall's pondweed. "Quanicassee Creek." C. A. Davis. 
Potamogeton heterophyllus Schreb. Various-leaved pondweed. "Cass River and millponds at Vassar and Caro." C. A. Davis.

Potamogeton pectinatus I. Fennel-leaved pondweed. "Millponds of Caro." C. A. Davis.

Najas flexilis (Wild.) Rostk. \& Schmilt. Slender najas. "I)ituhes in Akron and Wisner townships near the bay." C. A. Davis.

\section{JUNCAGINACEAE. Arrow Grass Family}

Triglochin maritima L. Seaside arrow-grass. In marshy places bordering the Saginaw Bay shore and near the small lakes.

Triglochin palustris I. Marsh arrow-grass. Occasional in wet sand along the Saginaw Bay beach. "Common on the prairies in Akron and Wisner townships." C. A. Davis.

\section{ALISMACEAE. Water Plantain Family}

Sagittaria latifolia Willd. Broad-leaved arrow-hearl. Common in wet places along the Saginaw Bay shore, ditches, slow streams and about the small lakes.

Sagittaria heterophylla Pursh. Sessile-fruited arrow-head. "In Cass River about Vassar." C.A. Davis.

Alisma planlago-aquatica L. Water plantain. Common in ditches, slow streams, wet and muddy places, and about the small lakes.

\section{HYDROCHARITACEAE. Frog's Bit Family}

Elodea canadensis Michx. Water-weed. Noticed in the small lakes and in the creek at Quanicassee.

Vallisneria spiralis L. Wild celery. Tape grass. "Millponds at Caro and Vassar. Ditches near Saginaw Bay." C. A. Davis. said to be an attractive food for wild ducks.

\section{GRAMINEAE. Grass Family}

Andropogon scoparius Michx. Broom beard-grass. Occasional on poor ground near the Saginaw Bay shore.

Andropogon furcatus Muhl. Forked beard-grass. Frequent in dry open places.

Sorghastrum nutans (I.) Nash. Indian grass. Wood grass. Noticed by Prof. C. A. Davis on low sand ridges in northern part of Akron Township.

Digitaria sanguinalis (L.) Scop. Crab grass. A common and ricious weed in gardens and fields.

Panicum capillare L. Old-witch grass. Common as a weed in gardens and fields. 
Panicum virgatum L. Switch grass. Occasional, growing in bunches along low sandy ridges near the Saginaw Bay shore. "Sandy areas and slopes of sand dunes, Akron Township." C. A. Davis.

Panicum depauperatum Muhl. Starved panicum. Frequent in poor sandy ground, especially on low sand ridges along the Saginaw Bay shore.

Panicum lindkeimeri Nash. Lindheimer's panicum. Frequent in prairie-like ground near the Saginaw Bay shore.

Panicum tennesscense Ashe. Tennessee panic grass. Often abundant in prairie-like ground near the Saginaw Bay shore.

Panicum scribnerianum Nash. Scribner's panicum. Noticed by Prof. C. A. Davis in prairie-like ground in northern part of Akron Township.

Panicum boscii Poir. Porter's panicum. "Common on the sand dunes along the bay and in dry woods throughout." ('. A. Davis.

Echinochloa crusgalli (L.) Beauv. Barnyard grass. A weed in fields and damp waste places.

Setaria glauca (L.) Beauv. Foxtail. Pigeon grass. A common weed in gardens and cultivated fields.

Setaria viridis (L.) Beauv. Green foxtail. Bottle grass. A common weed in fields and waste places.

Cenchrus carolinianus Walt. Sand bur. Bur grass. Becoming very common in light sandy ground along roads. Often a vicious weed in sandy fields and pastures.

Zizania aquatica L. Wild rice. Water oats. Indian rice. Occasional in shallow water and on mud along the Saginaw Bay shore, being from 2 to 3 feet high. Noticed also at Shay's Lake and Murphy's Lake. "Borders of marshy prairies in Akron Township. Also in shallow water in the bay near Fish Point." C. A. Davis. Not noticed as very abundant anywhere. A larger form now known as Zizania palustris L., larger wild rice, often more than 10 feet high is found about Iake St. Clair and Lake Erie. This was perhaps formerly very abundant about Saginaw Bay and may still exist there.

Leersia virginica Willd. White grass. Noticed in damp rich woods near Murphy's Lake. Very probably frequent throughout.

Leersia oryzoides (L.) Sw. Rice cut-grass. Scratch grass. Common in low marshy places, ditches and along slow streams.

Phalaris caveriensis L. Canary grass. Noticed as occasional in waste places of cities and villages.

Phalaris arundinacea L. Reed canary grass. Frequent in wet marshy places.

Phalaris arundinacea picta L. Ribbon grass. Frequently escaping from cultivation to marshy places and persisting. It is very prominent in white patches and can be seen from a long distance. 
Milium effusum L. Millet grass. In rich woods near Murphy's Lake. Probably occurring throughout.

Oryzopsis pungens (Torr.) Hitche. Dry and sandy ground. Frerpuent throughout.

Oryzopsis asperifolia Michx. White-grained mountain rice. Frequent in dry woods. Noticed in particular on the dry shaded hillsides about Murphy's Lake. "Dry woods in Cass River valley. Sand ridges Akron Township." C. A. Davis.

Stipa spartea Trin. Porcupine grass. Noticed as occasional on low sand ridges in the northeast part of the county. "Sandy ridges in Wisner Township near Bay Park." C. A. Davis.

Muhlenbergia mexicana (L.) Trin. Meadow muhlenbergia. Noticed by Prof. C. A. Davis near Unionville. Probably frequent throughout.

Muhlenbergia racemosa (Michx.) BSP. Marsh muhlenbergia. Common in damp places, especially on borders of marshes with other grasises and serlges.

Brachyelytrum erectum (Schreb.) Beauv. Brachyelytrum. "Dry woodlands throughout eastern part of county." C. A. Davis.

Phleum pratense L. Timothy. One of our best cultivated grasses. Common along roads, in fields, and often a weed in gardens.

Alopecurus geniculatus aristulatus Torr. Floating foxtail. Frequent in very wet places, especially in the vicinity of the small lakes.

Sporobolus cryptandrus (T'orr.) Gray. Sand dropseed. Frequent on low sand ridges and in sand along the Saginaw Bay beach.

Agrostis alba L. Red top. Common in damp and frequent in dry sandy ground. Very variable in size and general appearance.

Agrostis hyemalis (Walt.) BSP. Rough hair-grass. Occasional and in spots abundant on and near sand ridges, especially near the Saginaw Bay shore. "Islands in the prairies, Akron Township." C. A. Iaris. Agrostis perennans (Walt.) Tuckerm. Thin grass. ¿sually in damp partially shaded places, occasional in moist open ground.

Calamovilfa longifolia (Hook.) Hack. Long-leaved reed-grass. Occasional in sand, usually on the middle or upper beach along the Saginaw Bay shore. One of our best shore sand binders protecting mainly the sands from the action of the winds.

Calamagrostis canadensis (Michx.) Beauv. Bluc-joint griss. Frequent and in spots abundant throughout in damp and wet places, especially on damp prairie-like ground and about the small lakes.

Ammophila arenaria (I.) Link. Sea sand-reed. In sand along the Saginaw Bay shore, found even below the midclle beach and acting as one of our best known sand binders, protecting the beach from the action of waves. "Sand dunes, Akron and Wisner townships." C. A. Daris.

Cinna arundianacea L. Wood reed grass. In damp shaded ground near Murphy's Lake. Very probably frequent throughout. 
Koeleria cristata (L.) Pers. Koeleria. Noticed on dry sandy ground in many places.

Deschampsia flexuosa (L.) Trin. Common hair-grass. Dry sandy shaded ground. Frequent.

Avena sativa. L. Common oat. Frequently noticed in waste places of cities and villages.

Danthonia spicata (L.) Beauv. Common wild oat grass. Common in dry or open shaded ground, especially on dry hilly ground near the small lakes.

Spartina michauxiana Hitchc. Slough grass. In damp and marshy places, especially about the small lakes.

Phragmites communis Trin. Reed. Occasional in wet and marshy places but not noticed as abundant anywhere. "Marshes throughout. Covers considerable areas on the east side of Fish Point, Akron Township." C. A. Davis.

Eragrostis hypnoides (Lam.) BSP. Creeping eragrostis. "Sandy moist soil, banks of streams and ditches." C. A. Davis.

Eragrostis pilosa (L.) Beauv. Small tufted love-grass. Along railroads and in dry open places. Frequent throughout.

Eragrostis megastachya (Kocler) Link. Strong scented eragrostis. Open sandy ground and a common weed in garden and field.

Dactylis glomerata L. Orchard grass. Frequent in yards, streets and roads. Not noticed in cultivation.

Poa annua I. Low spear grass. Noticed mostly in lawns and streets of villages.

Poa compressa L. Canada blue grass. Wire grass. Fnglish blue grass. Common throughout in dry poor ground along roads, in fields, and on hills.

Poa triflora Gilib. Fowl meadow-grass. Damp open meadow-like ground and wet places. Frequent.

Poa pratensis L. June grass. Kentucky blue grass. Common throughout in pastures, lawns, and along roads. One of our very best pasture grasses.

Gilyceria canadensis (Michx.) Trin. Rattiesnake grass.

Glyceria nervata (IVilld.) Trin. Nerved manna-grass. Common in wet open places and damp open woods. "Marshes and wet prairies throughout." C. A. Davis.

Glyceria grandis Wats. Reed meadow grass. Frequent in damp and wet ground, especially in the vicinity of the small lakes.

Glyceria septentrionalis Hitchc. F'loating manna grass. Frequent in ditches, very wet places, borders of ponds and slow streams.

Glyceria borealis (Nash.) Batchelder. Slender manna grass. Abundant on the margin of a pond near Fostoria. Not noticed elsewhere.

Festuca octoflora Walt. Slender fescue grass. Common in dry poor 
ground, especially on dry hills. "Dry sandy soil especially in the prairie region of Akron and Wisner townships." C. A. Davis.

F'estuca ovina 1. Sheep's fescue. Frequent on poor dry ground and on low sand ridges.

Festuca elatior I. Meadow fescue. Oecasional along roads and in waste places of villages.

Ficstuca nutans Spreng. Nodding fescue grass. Noticed on the "islands" in the northern part of $A$ kron Township.

Bromus secalinus L. Common chess. Cheat. Noticed along roads and in the waste places of villages.

Bromus ciliatus L. Fringed brome grass. Frequent in damp shaderl ground, especially near the small lakes.

Bromus kalmii Gray. Kalm's chess. Wild chess. Noticed as frequent on dry shaded or open ground near the small lakes. "Dry sandy" soil in islands in the prairies, Akron Township." C. A. Daris.

Agropyron repens (L.) Beauv. Quack grass. Couch grass. Frequent about villages and along railroads. A vicious weed in cultivatred grounds.

Agropyron dasystachyum (Hoak.) Scribn. Northern wheat-grass. occasional on and near the Saginaw Bay beaches.

Agropyron caninum (L.) Beauv. Awned wheat grass. Occasional in dry open woods.

Secale cereule L. Rye. Common as a weed about Mayville along roads, in cultivated fields and pastures. Apparently well established.

Hordeum jubatum L. Squirrel-tail grass. Frequent in the waste places of villages, and fast invading damp hayfields and pastures. Apparently a bad weed.

Elymus virginicus 1. Virginia wild rye. In damp open or partially shaded ground. Frequent.

Elymus canadensis L. Nodding wild rye. Frequent in sand on the upper beach of Saginaw Bay. Oceasional in other places. "Sand dunes near Saginaw Bay." C. A. Davis.

Hystrix patula Moench. Bottle brush grass. Common in rich open woods.

\section{CYPERACEAE. Sedge Family}

Cyperus diandrus Torr. I.ow eyperus. Frequent in damp and wet ground, and often in damp sand on the beach of Saginaw Bay.

Cyperus rivularis Kunth. Shining cyperus. "Beaches Akron Township." C. A. Davis.

Cyperus esculentus L. Yellow nut grass. "Moist sandy soil, Columbia Township." C. A. Davis.

Cyperus strigosus L. Straw-colored eyperus. Firequent in dimp grassy ground. 
Cyperus filiculmus Vahl. Slender cyperus. Occasional throughout in dry poor open ground.

Dulichium arundinaceum (L.) Britton. Dulichium. In very wet places, especia"ly near the small lakes and low banks of slow streams.

Eleocharis obtusa (Willd.) Schultes. Blunt spike rush. "Wet mud near the bay in Akron Township." C. A. Davis. "Frequent throughout the county.

Eleocharis palustris (L.) R. \& S. Creeping spike rush. Common in wet marshy places.

Eleocharis palustris glaucescens (Willd.) Gray. Creeping spike rush. Noticed by Prof. C. A. Davis in damp places near the shore of Saginaw Bay.

Eleocharis palustris vigens Bailey. Larger creeping spike rush. In wet places or shallow water about small lakes. Plentiful.

Eleocharis acicularis (L.) R. \& S. Needle spike rush. "Wet sandy soil along ditches and the beach of Saginaw Bay in Akron and Wisner townships." C. A. Davis.

Eleocharis tenuis (Willd.) Schultes. Slender spike rush. Common in damp open ground.

Eleocharis rostellata Torr. Beaked spike rush. "Wisner Township in swales along the base of the dune line next to the shore of the bay." C. A. Davis.

Scirpus pauciflorus Lightf. Few-flowered club rush. Noticed by Prof. C. A. Davis in wet ground along the shore of Saginaw Bay where it formed dense carpets below the storm wave line.

Scirpus subterminalis Torr. Water club-rush. In shallow water of ponds, caves and small lakes. Frequent.

Scirpus americanus Pers. Three-square. Comrnon along the shore of Saginaw Bay, about ponds, the small lakes, and along low banks of slow streams.

Scirpus ralidus Vahl. Great bulrush. Common in wet places, margins of ponds and small lakes.

Scirpus occidentalis (Wats.) Chase. Western bulrush. Shay's Lake, Cat Lake, Murphy's Lake, and in shallow water often extending far out into the water along the shore of Saginaw Bay.

Scirpus atrozirens Muhl. Dark-green bulrush. Common in wet marshy open places and often in damp ground along roads.

Scirpus lineatus Michx. Reddish bulrush. Noticed in marshy ground about Shay's Lake. Probably frequent throughout.

Scirpus cyperinus pelius Fernald. Wool grass. Common throughout in wet marshy open places.

Eriophorum callitrix Cham. Hare's-tail. Frequent in bogs.

Eviophorum viridi-carinatum. (Engelm.) Fernald. Tall cotton grass. 
Noticed in very wet open places about Cat Lake. Probably frequent throughout.

Eriophorum virginicum L. Virginia cotton grass. Frequent in boggy places about Cat Iake. Not noticed elsewhere.

Rynchospora alba (L.) Vahl. White beaked rush. In boggy ground at Quanicassee and Cat Lake.

Rynchospora capillacea Torr. Capillary beaked rush. Noticed by Prof. C. A. Davis in wet marshy ground near the shore of Saginaw Bay.

Rynchospora glomerata (L.) Vahl. Clustered beaked rush. "Prairies, Akron Township." C. A. Davis.

Scleria verticillata Muhl. Low nut rush. "In prairic-like ground in the northern part of Akron Township." C. A. Davis.

Cladium mariscoides (Muhl.) Torr. Twig-rush. Bogs and often in wet sand. Frequent.

Carex scoparia Schkuhr. Pointed broom sedge. Frequent and often abundant in wet marshy ground, especially in places where it is quite wet in spring and fall, but liable to be dry and spongy in summer.

Carex tribuloides Wahlend. Blunt broom sedge. Common in very wet marshy places.

Carex siccata Dewey. Hillside sedge. Occasional on shaded sand ridges near shore of Saginaw Bay.

Carex cristata Schwein. Crested sedge. Frequent in wet shaded ground.

Carex mirabilis perlonga Fernald. Larger straw sedge. Noticed in shaded ground near Akron.

Carex straminea Willd. Straw sedge. Noticed by Prof. C. A. Davis near Unionville.

Carex stellulata Good. Little prickly sedge. Low wet open ground. Common throughout.

Carex stellulata cephalantha (Bailey) Fernald. Larger prickly sedge. "Prairies and wet meadows throughout.". C. A. Davis.

Carex scirpoides Schkuhr. Inland sedge. In damp marshy piaces near Cat Lake and Murphy's Lake. (More recent approved name is C. interior Bailey.)

Carex bromoides Schkuhr. Brome-like sedge. In very swampy places near Cat Lake and the other small lakes.

Carex deweyana Schwein. Newey's sedge. Noticed on the banks of the small lakes. "Rich low woods, Fairgrove Township." C. A. Davis.

Carex tenuiflora Wahlend. Sparse-flowered seclge, open boggy ground. Frequent.

Carex trisperma Dewey. Three-fruited sedge. Shaded hoggy ground. Plentiful in tamarack-blark spruce swamps.

Carex trisperma billingsii Knight. Billings' sedge. Tamarack-black 
spruce swamps. Plentiful. Very small and slender but resembling the preceding.

Cartx tenella Schkuhr. Soft-leaved sedge. Swamps and margins of wet woods. Frequent.

Carex rosea Schkuhr. Stellate sedge. In rich woods near Murphy's Iake. Probably frequent throughout.

Carex rosea radiata Dewey. Ray-like sedge. In damp woods near Mayville. Frequent.

Carex muhlenbergii Schkuhr. Muhlenberg's sedge. Frequent on poor sandy ground.

Carex cephalophora Muhl. Oval-headed sedge. "Clay soil on oak islands, Akron Township." C. A. Davis.

Carex sparganioides Muhl. Bur-reed sedge. In damp rich woods near Murphy's Lake. Probably frequent throughout.

Carex vulpinoidea Michx. Fox sedge. Common throughout in low open ground.

Carex diandra Shrank. Lesser panicled sedge. In wet boggy ground near Akron, probably frequent throughout.

Carex diandra ramosa (Boott) Fernald. Prairie sedge. In very wet and boggy ground near ('at Lake.

Carex stipata Muhl. Awl-fruited sedge. Common in very wet open or partially shaded places, especially about the small lakes.

Carex surtuellii Dewey. Sartwell's sedge. In very wet open marshy ground, especially about the small lakes.

Carex crinita Lam. Fringed sedge. Occasional in and near open or partially shaded places.

Carex aquatilis Wahlenb. Water sedge. Frequent in wet places near the shore of Saginaw Bay, and occasional near the small lakes. According to K. K. Mackenzie of New York City, we do not have C. aquatilis in this part of Michigan, but rather a variety, $C$. aquatilis substricta Kï̈kenthal. Smaller water sedge.

Carex strictu Lamb. Tussock sedge. In boggy places near the smal! lakes.

Carex aurea Nutt. Golden-fruited sedge. Damp grassy shaded or open places. Frequent.

Carex leptalea Wahlenb. Bristle-stalked sedge. In swamps near the small lakes. Plentiful.

Carex polygama Schkuhr. Brown sedge. Common in wet marshy places about the small lakes and in prairie-like ground in the northern part of the county.

Carex gracillima Schwein. Graceful sedge. In rich woods near Murphy's Lake. Probably frequent throughout.

Carex communis Bailey. Fibrous-rooted sedge. Noticed in rich woods in Almer Township by C. A. Davis. Probably frequent throughout. 
Carex varia Muhl. Emmons' sedge. Dry sterile open grounnl. Fre quent.

Carex pennsylvanica Lam. Pennsylvania sedge. Common in dry open or shaded ground.

Carex tetanica Schkuhr. Woorl's sedge. Frequent in wet open ground about the small lakes.

Carex laxiflora blanda (Dewey) Boott. Loose-flowered sedge. C'ommon in woods near Akron. Probably frequent throughtout.

Carex laxiflora latifolia Boott. White bear sedge. Quite abundant in rich woods near Murphy's Lake. Probably frequent throughout.

Carex conoidea Schkuhr. Field sedge. "Prairies, Akron and Wisner townships." C. A. Davis.

Carex granularis Muhl. Meadow sedge. In meadow-like ground near Cat Lake. Probably frequent throughout.

Carex crawei Dewey. Crawe's sedge. In prairie-like ground in northern part of county. "Common in swales along the shores of bay in Akron and Wisner townships." C. A. Davis.

Carex flava L. Yellow sedge. In wet marshy places near the lakes. Common throughout.

Carex oederi pumila (Cosson \& Germain) Fernald. Green sedge. In damp sand along the shore of Saginaw Bay. "Wet, muddy and sandy shores of Saginaw Bay below storm wave mark." C. A. Davis.

Carex filiformis L. Slender sedge. Common in wet prairie-like ground in northern part of county and in wet places about the small lakes. "Common about lakes in Dayton and Watertown tornships. Mud Lake, Arbela Township. Also on prairies." C. A. Daris.

Carex lanuginosa Michx. Woolly sedge. In wet marshy places, especially about the small lakes and at Quanicassee.

Carex ripuria W. Curtis. River-bank sedge. In very wet places near the shore of Saginaw Bay and about the small lakes.

Carex pseudo-cyperus L. Cyperus-like sedge. In very wet places near the shore of Saginaw Bay and about the small lakes. Frequent.

Carex comosa Boott. Bristly sedge. In wet spots on the prairies and about the small lakes.

Carex hystericina Muhl. Porcupine sedge. Common throughout in wet places.

Carex lurida Wahlenb. Sallow sedge. Frequent in swampy places near the small lakes.

Carex retrorsa Schwein. Retrorse serlge. In wet places near the small lakes.

Carex retrorsa hartii (Dewey) Gray. Hart Wright's sedge. "Shaded swampy places in Akron and Columbia townships." C. A. Davis.

Carex lupulina Muhl. Hop sedge. In wet mostly open places near Murphy's Lake. Probably frequent throughout. 
Carex grayii Carey. Gray's sedge. In rich woods near Murphy's Lake. Probably common throughout.

Carex intumescens Rudge. Bladder sedge. In rich woods near Murphy's Lake. Probably frequent throughout.

\section{ARACEAE. Arum Family}

Arisaema triphyllum (I.) Schott. Jack-in-the-pulpit. Indian turnip. Common throughout in damp rich woods.

Calla palustris L. Wild calla. Water arum. "Swamps in Dayton and Arbela townships." C. A. Davis.

Symplocarpus foetidus (L.) Nutt. Skunk cabbage. Abundant in shaded ground along and on the banks of a small creek near Murphy's Lake. "Common in swampy woods, Dayton Township." C. A. Davis. Acorus calamus I. Sweet flag. In a wet place on border of Shay's Lake. Probably frequent throughout.

\section{LEMNACEAE. Duckweed Family}

Spirodela polyrhiza (I.) Schleid. Greater duckweed. Common about ponds and stagnant pools on mud and shallow water. "Common in ditches and ponds." C. A. Davis.

Lemna minor L. Lesser duckweed. Floating on stagnant water about the small lakes.

\section{PONTEDERIACEAE. Pickerel-weed Family}

Pontederia cordata L. Pickerel weed. In large ponds and shallow water of the small lakes. Frequent.

\section{JUNCACEAE. Rush Family}

Juncus bufonius L. Toad rush. "Moist roadsides and wet places along ditches. Often very abundant." C. A. Davis.

Juncus tenuis Willd. Slender rush. Yard rush. Common on roadsides and along paths.

Juncus balticus littoralis Engelm. Baltic rush. Occasional in sand on the beach of Saginaw Bay, and in damp places throughout. An excellent sand binder, holding the shore sands firmly in place against the action of wind and wave.

Juncus effusus L. Common rush. Soft rush. Common in wet and marshy ground. Noticed as often abundant in damp pastures.

Juncus brachycephalus (Engelm.) Buchenau. Small-headed rush. Marshy places and wet shores. Frequent.

Juncus brevicaudatus (Engelm.) Fernald. Narrow-panicled rush. Wet muddy, or damp places about ponds, small lakes, low banks of small streams and wet shores. Frequent. 
Juncus canadensis J. Gay. Canada rush. Occasional in marshy places near the small lakes and in prairie-like ground in the northern part of Akron Township.

Juncus pelocarpus Mey. Brown-fruited rush. Wet gravelly or sandy low beaches of small lakes and in open swampy places. Frequent.

Juncus nodosus I. Knotted rush. Frequent in prairie-like ground in Akron Township and probably occurring throughout.

Juncus torreyi Coville. Torrey's rush. Noticed in prairic-like ground in northern part of Akron Township by Prof. C. A. Davis.

Juncus alpinus insignis Fries. Richardson's rush. Occasional in damp sand along the shore of Saginaw Bay.

Luzula saltuensis Fernald. Hairy wood rush. Common throughout in damp shaded ground.

Lusula campestris multiflora (Ehrh.) Celak. Common wood rush. Common in old fields and dryish open woods.

\section{LILIACEAE. Lily Family}

Tofieldia glutinosa (Michx.) Pers. Glutinous tofieldia. Damp marshy ground. Frequent.

Uvularia grandiflora Sm. Large-flowered bellwort. Frequent in rich woods. Noticed especially in rich woods near Murphy's Lake.

Oakesia sessilifolia (I.) Wats. Sessile-leaved bellwort. In rich open woods near Murphy's Lake.

Allium tricoccum Ait. Wild leek. "Rich woodlands, Columbia and Akron townships." C. A. Davis.

Allium canaderise L. Wild garlic. "Moist open sandy soil borders of the prairies, Akron and Wisner townships." C. A. Davis.

Hemerocallis fulva L. Common day lily. Noticerl as a well established escape throughout, on roadsides and in waste places.

Lilium philadelphicum andinum (Nutt.) Ker. Western red lily. "Dry sandy ridges near Saginaw Bay in Akron Township." C.. A. Davis.

Lilium superbum L. Turk's-cap lily. Noticed in rich open woods near Murphy's Lake and on the "islands" in northern part of county.

Erythronium americanum Ker. Yellow adder's tongue. Y'ellow dog'stooth violet. Noticed as frequent in rich woods.

Asparagus officinalis I. Garden asparagus. Occasional along roads and in open dry woods. Frequent.

Clintonia borealis (Ait.) Raf. Yellow clintonia. Common in the swamps near Cat Lake. Probably throughout.

Smilacina racemosa (L.) Desf. False spikenard. Common in moist shaded ground and on steep shaded banks of small streams.

Smilacina stellata (L.) Desf. Star-flowered Solomon's seal. Frequent 
in rich shaded ground and common in shaded sandy places near the beach of Saginaw Bay.

Smilacina trifolia (L.) Desf. Three-leaved Solomon's seal. In wet places near Cat Lake. Plentiful.

Maianthemum caradcnse Desf. False lily of the valley. Common in rich shaded ground. "Common in dry woods. Also in sandy plains in Indianfields and Vassar townships." C. A. Davis.

Strepitopus roseus Michx. Sessile-leaved twisterl stalk. Rich damp woods. Frequent throughout.

Polygonatum biflorum (Walt.) Ell. Small Solomon's seal. Frequent in rich woods.

Convallaria majalis $\mathrm{I}$. I. Iily of the valley. Apparently escaping and persisting.

Medeola virginiana L. Indian cucumber-root. In rich shaded ground near Cat Lake. Probabiy frequent throughout.

T'rillium erectum L. Red trillium. Ili-scented wake robin. Common in rich woods near Murphy's Lake. Probably frequent throughout.

Trillium grandiflorum (Michx.) Salisb. White trillium. Largeflowered wake robin. In rich woods near Murphy's Lake. Very probably appearing in many places throughout the county.

Smilax herbacea L. Carrion flower. Occasional in rich shaded ground. "Borders of sand dunes and oak islands in the prairies of Akron and Wisner townships." C. A. Davis.

Smilax ecirrhata (Engelm.) Wats. Upright smilax. In rich woods near Murphy's Lake. Very pro!)ably frequent throughout.

Smilax hispida Muhl. Hispid greenbrier. Frequent in woods and thickets. "Low rich woodlands and thickets Columbia and Akron townships." C. A. Davis.

\section{DIOSCOREACEAE. Yam Family}

Dioscorea villosa L. Wild yam-root. Common on borders of woods and in thickets. It is claimed by Harley Harris Bartlett in Bulletin 189, United States Department of Agriculture, Bureau of Plant Industry, that the correct name of our plant is Dioscorea paniculata Michx.

AMARYLLIDACEAE. Amaryllis Family

Hypoxis hirsuta (L.) Coville. Star grass. Common on borders of prairie-like land in northern part of county. "Prairies, $A$ kron and Wisner townships." C. A. Davis.

IRIDACEAE. Iris Family

Iris versicolor L. Larger blue flag. Frequent in wet open places, but seldom abundant. 
Sisyrinchium angustifolium Mill. Pointed blue-eyed grass. ()ecasional in damp or dry ground.

Sisyrinchium gramineum Curtis. Common blue-eyed grass. "Ahundant on sandy 'islands', Akron Township." C A Davis.

\section{ORCHIDACEAE. Orchis Family}

Cypripedium parviflorum Salisb. Small yellow 'lady's slipper. In open swampy and boggy places. Frequent.

Cypripedium parviflorum pubescens (Willd.) Knight. I argel yellow lady's slipper. In a tamarack swamp near Cat Lake.

Cypripedium hirsutum Mill. Showy lady's slipper. In swamps about the small lakes.

Cypripedium acaule Ait. Stemless lady's slipper. Growing in sphagnum in a spruce-tamarack swamp near Cat Lake. Probably found throughout.

Orchis spectabilis L. Showy orchis. Rich shaded groun!l. Frecjuent.

Habenaria bracteata (Willd.) R.Br. Long-bracted orchis. Damp woods and thickets. Frequent.

Habenaria hyperborea (L.) R.Br. 'Tall leafy green orchis. Damp woods. Frequent.

Habenaria dilatata (Pursh) Gray. Tall white bog orehis. Very wet open places about the small lakes. Frequent.

Habenaria hookeri Torr. Hooker's orehis. Noticed in woods near Murphy's Lake. Probably frequent throughout.

Iiabenaria orbiculata (Pursh) Torr. Large round-leared orchis. Rich shaded ground. Occasional.

Habenaria blephariglottis (Willd.) Torr. White-fringed orchis. Nhmdant in a spruce-tamarack swamp northwest of Cat Lake on the farm of F. E. Warner. Not noticed elsewhere.

Habenaria lacera (Michx.) P.Br. Ragged orchis. Mostly in wet open ground. Frequent.

IIabenaria leucophnea (Nutt.) Gray. Prairie white-fringed orchis. "Frequent on the open prairies of Akron Township." C. A. Daris.

Habenaria psycodes (L.) Sw. Smaller purple-fringed orchis. "Roalsides in swamps, Kovlton Township." C. A. Daris.

Pogonia ophioglossoides (L.) Ker. Rose pogonia. Open marshy and boggy places. Frequent.

Calopogon pulchellus (Sw.) R.Br. Grass pink. Calopogon. Mbundant in a spruce-tamarack swamp northwest of Cat Lake. Probah!y frepurent throughout.

Spiranthes gracilis (Bigel.) Beck. Dry mostly open ground. ()“cilsional. Perhaps overlooked.

Spiranthes cernua (L.) Richard. Nodding ladies' tresses. Noticed about Mud Lake southwest of Fostoria. "Moist grassy places, Fremont 
Township. Also in swales between dune lines on the prairies in Akron Township." C. A. Davis.

Liparis loeselii (L.) Richard. Fen orchis. Noticed in a swampy place near Mud Lake southwest of Fostoria. Probably frequent throughout.

Aplectrum hyemale (Muhl.) Torr. Putty-root. Rich shaded ground. Frequent.

\section{PIPERACEAE. Pepper Family}

Saururus cernuus L. Lizard's tail. "Occasional along streams in Columbia Township." C. A. Davis.

SALICACEAE. Willow Family

Salix nigra Marsh. Black willow. Common in low places especially along small streams. Occasional in damp sand on the beach of Saginaw Bay.

Salix amygdaloides Anders. Peach-leaved willow. Common in rich damp ground and usually mixed with other trees. "Borders of the prairies and on low sand dunes along Saginaw Bay in Akron and Wisner townships." C. A. Davis.

Salix pentandra L. Ivy-leaved willow. Occasionally planted as an ornamental tree. Not sprearling.

Salix lucida Muhl. Shining willow. Common in damp and swampy ground with other willows.

Salix serissima (Bailey) Fernald. Autumn willow. In low ground near Cat Lake. Pistillate catkins were still clinging to the tree August 6, 1910 .

Salix alba L. White willow. Planted for ornament and inclined to escape.

Salix alba vitellina (L.) Koch. Golden willow. "Planted in many places as a shade tree." C. A. Davis.

Salix babylonica L. Weeping willow. Planted as an ornamental tree but not escaping.

Salix longifolia Muhl. Sand-bar willow. Common in low places, about the small lakes, and along the banks of small streams.

Satix pedicellaris Pursh. Bog willow. Wet open boggy places. Frequent.

Salix discolor Muhl. Glaucus willow. Frequent in low places with other willows.

Salix petiolaris Sm. Slender willow. Common in wet ground, especially in the vicinity of the small lakes.

Salix humilis Marsh. Prairie willow. Noticed on low sand ridges in the northern part of Akron Township by Prof. C. A. Davis. Probably frequent throughout. 
Salix sericea Marsh. Silky willow. Wet open ground. Trequent.

Salix rostrata Richards. Bebb's willow. Noticed in dryish ground near Murphy's Lake. Probably common throughout.

Salix candida. Flügge. Sage willow. Hoary willow. In boggy places, especially about the small lakes. Frequent.

Populus alba L. White poplar. Planted as an ornamental tree in villages and inclined to spread by root. Noticed only pistillate catkins.

Populus tremuloides Michx. Common poplar. American aspen. Common throughout. Often springing up very thick on burned-over and low drained ground.

Populus grandidentata Michx. Largè-toothed aspen. Frequent on dry and hilly ground with other trees.

Populus balsamifera L. Balsam poplar. Common in sandy ground on and near the shore of Saginaw Bay, and frequent in other places. "Common in the sandy parts of Cass River valley in Indianfields, Wells and Novesta townships." C. A. Davis.

Populus deltoides Marsh. Cotton-wood. Frequent throughout in rich ground with other trees. "Frequent in the vicinity of Saginaw Bay and in moist places generally." C. A. Davis.

Populus nigra italica DuRoi. Lombardy poplar. Planted as an ornamental tree and inclined to spread by root.

\section{MYRICACEAE. Sweet Gale Family}

Myrica asplenifolia L. Sweet fern. Noticed on poor ground west of Murphy's Lake. "I.ight sandy soil, Indianfields and Wells townships." C. A. Davis.

JUGLANDACEAE. Walnut Family

Juglans cinerea I. Butternut. Frequent throughout in rich ground with other trees. "Arbela and Millington townships." C. A. Daris.

Juglans nigra L. Black walnut. Mostly planted, but small apparently native trees occasionally noticed in rich ground. "Along the Cass River below Vassar." C. A. Davis.

Carya ovata (Mill.) K. Koch. Shag-bark hickory. Frequent throughout. Many large trees noticed with other trees. "Trequent in the southeastern part of the county." C. A. Davis.

Carya cordiformis (Wang) K. Koch. Bitter nut. Frequent in rich ground with other trees.

\section{BETULACEAE. Birch Family}

Corylus americana Walt. Common hazelnut. Noticed in particular as abundant on some of the islands in the north part of Akron Township. "Common in wood and brush lands throughout." C. A. Daris.

Ostrya virginiana (Mill.) K. Koch. Ironwood. Common in rich 
ground with other trees, especially in the vicinity of the small lakes. "Common with the beech and hard maple." C. A. Davis.

Carpinus caroliniana Walt. Blue beech. Common in damp rich ground with other trees.

Belula lutea Michx.f. Yellow birch. Frequent in rich ground with other trees. Prof. C. S. Sargent of the Arnold Arboretum, Jamaica Plain, Mass., is inclined to call this birch Betula allegheniensis Britton, southern yellow birch, and doubts whether we have Betula lenta L., cherry birch, in Michigan or western Ontario.

Betula alba papyrifera (Marsh.) Spach. White birch. Paper birch, Canoe birch. Common throughout in rich or poor ground with other trees.

Betula pumila L. Low birch. Abundant in the swamps about Cat Lake and Mud Lake.

Alnus incrana (L.) Moench. Speckled alder. Common in wet rich ground especially along streams and about the small lakes. Often abundant.

\section{FAGACEAE. Beech Family}

Fagus grandifolia Ehrh. Common beech. Common in rich ground with other trees. Often noticed on good hilly land. "Formerly abundant on the better drained clayey soils and on the moraines." C. A. Davis.

Castanea dentata (Marsh.) Borkh. Chestnut. "A few trees by the roadside in Millington Township, apparently planted." C. A. Davis.

Quercus alba $\mathrm{L}$. White oak. Reported as formerly very abundant, but most of the large and valuable trees were cut many years ago for stares and lumber. Now confined mostly to small trees on hilly, sandy and gravelly land.

Quercus macrocarpa Michx. Bur oak. Frequent throughout and usually in rich ground with other trees.

Quercus bicolor Willd. Swamp white oak. Frequent throughout with other trees and usually in rich ground. In Akron Township west of Unionville on the north side of the road, this and the preceding species have been set out for some distance as ornamental trees and they appear to be a striking success.

Quercus muhlenbergii Engelm. Chestnut oak. "Watertown Township." C. A. Davis.

Quercus rubra L. Ped oak. Common throughout with other trees, both in damp rich and dry poor ground.

Quercus coccinea Moench. Scarlet oak. "Sand dunes and plains in Cass River valley." C. A. Davis.

Quercus velutina Lam. Yellow-barked oak. Black oak. "Sandy island in the prairies and on the dunes along the bay shore in Akron and Wisner townships." C. A. Davis. 


\section{URTICACEAE. Nettle Family}

Ulmus fulva Michx. Slippery elm. Red elm. "Common along streams." C. A. Davis.

Ulmus americana L. American elm. White elm. Very common throughout in rich ground with other trees.

Ulmus racemosa Thomas. Rock elm. Cork elm. In rich ground with other trees near Murphy's Lake. Noticed also on the "islands" by Prof. C. A. Davis.

Cannabis sativa L. Hemp. Occasional as an escape in cities and villages.

Humulus lupulus L. Common hop. Hops. Inclined to escape and persist along fences.

Maclura pomifera (Raf.) Schneider. Osage orange. Planted for hedges and inclined to persist, but not spreading. Apparently not a success for hedge purposes in this locality.

Urtica gracilis Ait. Slender nettle. Common in rich wools, open damp places, and often inclined to be a weed.

Laportea canadensis (L.) Gaud. Wood nettle. In rich woods, especially near Murphy's Lake. Probably frequent throughout.

Pilea pumila (L.) Gray. Richweed. Clearweed. Common in damp) rich woods and thickets.

Boehmeria cylindrica (L.) Sw. False nettle. Frequent in moist shaded or open ground, especially near the small lakes.

SANTALACEAE. Sandalwood Family

Comandra richardsiana Fernald. Richard's bastard toad-flax. Common throughout in dry poor ground. Formerly included in C. umbellata (L.) Nutt.

ARISTOLOCHIACEAE. Birthwort Family

Asarum canadense L. Wild ginger. In rich woods near Murphy's Lake. Probably appearing throughout.

\section{POLYGONACEAE. Buckwheat Family}

Rumex britannica L. Great water dock. Common in swamps and wet places, especially about the small lakes.

Rumex crispus L. Yellow dock. Common as a weed along roads, in hay fields and damp meadows.

Rumex verticillatus L. Swamp dock. Occasional in very wet places and often in shallow water, especially along the low wet banks of small streams.

Rumex obtusifolius I. Bitter dock. Frequent and often common as a weed along roads, in yards, cultivated fields, and open woods. 
Rumex acetosella L. Field sorrel. Sheep sorrel. A common weed, especially in old fields.

Polygonum aviculare I. Knotgrass. Door-weed. Common as a weed in yards, fields and along roads.

Polygonum erectum L. Erect knotweed. Common as a weed in yards and waste places.

Polygonum lapathifolium L. Slender pink persicaria. Frequent in wet places, especially near the small lakes, and often a weed in gardens and cultivated fields.

Polygonum amphibium L. Water persicaria. Common about ponds and small lakes in very wet places. Often in shallow still water, when in general appearance it much resembles a pond weed.

Polygonum muhlenbergii (Meisn.) Wats. Swamp persicaria. In very wet places and often in water near and about the small lakes.

Polygonum pennsylvanicum L. Pennsylvania persicaria. Common in moist open or shaded ground.

Polygonum hydropiper L. Common smartweed. Frequent in moist open or shaded ground.

Polygonum acre HBK. Water smartweed. Common in wet places about the small lakes and along the low grassy banks of small streams.

Polygonum orientale L. Prince's feather. Occasionally escaping from cultivation to roads and near-by fields. Often a weed in gardens.

Polygonum persicaria I. Lady's thumb. Frequent in damp places, along banks of ditches, and often a roadside weed.

Polygonum hydropiperoides Michx. Wild water pepper. In ditches and in and along small streams.

Polygonum virginianum L. Virginia knotweed. In rich woods near Murphy's Lake.

Polygonum sagittatum L. Arrow-leaved tear-thumb. In wet places about Mud Lake southwest of Fostoria. Very probably appearing in many other wet places.

Polygonum convolvulus L. Black bindweed. Everywhere as a weed in cultivated and waste places.

Polygonum cilinode Michx. Fringed black bindweed. On sides of dry hills near Cat Lake and Mud Lake. "Dry woods on the east side of Dayton Township." C. A. Davis.

Polygonum scandens L. Climbing buckwheat. Frequent on horders of woods and thickets, especially in the vicinity of the small lakes.

Fagopyrum esculentum Moench. Buckwheat. Occasional as an escape along roads, in fields, and about farm buildings.

Polygonella articulata (L.) Meisn. Coast jointweed. Noticed by Prof. C. A. Davis on sand ridges near the shore of Saginaw Bay. 
CHENOPODIACEAE. Goosefoot Family

Cycloloma atriplicifolium (Spreng.) Coult, Winged pigweed. "In light sand, Indianfields Township, near Caro." C. A. Davis. Sproading as common weed.

Kochia scaparia (L.) Schrod. Kochia. Inclined to escape from cultivation and persist.

Chenopodium botrys L. Jerusalem oak. Feather geranium. ()ceasional about depot grounds in villages. "Sand clunes and dry sand near Bay Park, Akron Township." C. A. Davis.

Chenopodium capitatum (L.) Asch. Strawberry blite. Noticed on the border of a newly cleared and plowed field near Cat Lake. "Frequent in moist soil throughout." C. A. Davis.

Chenopodium glaucum L. Oak-leaved goosefoot. Occasional as a harmless weed in gardens and the streets of villages.

Chenopodium hybridum L. Maplc-leaved goosefoot. Occasional as a weed in gardens, especially bean fields, open woods and along roads.

Chenopodium album L. Common pigweed. Lamb's quarters. A very common weed in all cultivated grounds.

Beta vulgaris L. Sugar beet. Noticed in several oat fields, with small but sweet root. After a crop it is said to persist two or more years.

Atriplex patula hastata (I.) Gray. Halberd-leaved orache. Noticed in streets of villages and in depot grounds.

Salsola tenuifolia G. F. W. Mey. Russian thistle. Noticed as a weed in villages especially about depot grounds. "Sandy roadside, terrace of Cass River opposite Caro, and near the railway crossing at Vassar." C. A. Davis.

\section{AMARANTHACEAE. Amaranth Family}

Amaranthus retroflexus L. Amaranth pigweed. Green amaranth. A common weed in cultivated grounds and often called red root.

Amaranthus hybridus forma hypochondriacus (L.) Robinson. Slender pigweed. "Escaped from cultivation in a few places." C. .. Davis.

Amaranthus graecizans I. Tumble weed. A weed in cultivated grounds, especially corn fields.

Amaranthus blitoides Wats. Prostrate amaranth. A recent weed from the West noticed mostly in gardens and villages, but occasionally in cultivated fields.

\section{AIZOACEAE. Carpet Weed Family}

Mollugo verticillata $I_{\text {. }}$ Carpet weed. Occasional on sandy roadsides. Sperzula arvensis L. Corn spurry. Often as a weed in gardens and grain fields. 


\section{CARYOPHYLLACEAE. Pink Family}

Arenaria serpyllifolia L. Thyme-leaved sandwort. Common as a weed in dry poor ground about villages, along roads and in cultivated grounds.

Stellaria longifolia Muhl. Long-leaved stitchwort. Common in damp and marshy places, especially in the vicinity of the small lakes.

Stellaria graminea L. Lesser stitchwort. Grassy places in cemeteries and villages. Frequent.

Stellaria media (L.) C. Trill. Common chickweed. A common weed in gardens, fields and open woods.

Cerastium vulgatum L. Common mouse-ear chickweed. Common as a weed in gardens, fields and open woods.

Agrostemma githago L. Cockle. Corn cockle. Noticed as a frequent weed in wheat fields and waste places.

Lychnis coronaria (L.) Desr. Mullein pink. "Escaped from cultivation around cemeteries and houses in a few places." C. A. Davis.

Lychnis alba Mill. White campian. Becoming a common weed in cultivated grounds.

Silene antirrhina L. Sleepy catchfly. Frequent throughout in dry sandy ground.

Silene noctiflora L. Night-flowering catchfly. Noticed as occasional along roads, in waste places, and about farm buildings.

Saponaria officinalis L. Bouncing Bet. Soapwort. Occasional as a weed along roads and in dry sandy places. Fast spreading.

Saponaria vaccaria L. Cow-herb. A recent weed appearing along railroads and in waste places of cities and villages. Frequent.

Dianthus armeria L. Deptford pink. Noticed along the road north of Mayville.

\section{PORTUlACACEAE. Purslane Family}

Claytonia virginica L. Spring beauty. Common in damp rich woods.

Portulaca oleracea L. Common purslane. A common weed in gardens, fields, and waste places.

\section{NYMPHAEACEAE. Water Lily Family}

Nymphaea advena Ait. Yellow pond lily. Cow lily. Common in still and stagnant water, especially about ponds and the small lakes.

Castalia tuberosa (Paine) Greene. White water lily. Frequent throughout in ponds, coves and margins of small lakes.

Brasenia schreberi Smel. Water slime. Ponds, coves, small lakes and sluggish streams. Frequent. 
RANUNCULACEAE. Crowfoot Family

Ranunculus circinatus Sibth. Stiff water crowfoot. Noticel in still water at Quanicassee. "In millponds at Caro and Vassar." ('. A. Daris.

Ranunculus delphinifolius Torr. Yellow water crowfoot. ('ommon in ditches, pools, borders of ponds, and slow streams.

Ranunculus sceleratus L. Cursed crowfoot. Common in ditches and wet open places.

Ranunculus abortivus L. Small-flowered crowfoot. Very common in damp shaded ground.

Ranunculus recurvatus Poir. Hooked crowfoot. Common in rich shaded ground.

Ranunculus septentrionalis Poir. Swamp buttercup. Usually noticed and frequent in damp rich shaded ground, but sometimes in open marshy places.

Ranunculus pennsylvanicus L.f. Bristly crowfoot. Frequent throughout in damp grassy places.

Ranunculus acris I. Tall crowfoot. Occasional along roads and in pastures.

Thalictrum dioicum L. Early meadow rue. Common, often abundant in rich shaded ground. "'Islands' in the prairies, Aliron Township." C. A. Davis.

Thalictrum dasycarpum Fisch. \& Lall. Purplish meadow rue. Frequent and often abundant on borders of swamps and low banks of streams. "Common on the borders of the prairies and in open swamps generally." C. A. Davis.

Hepatica triloba Chaix. Round-lobed liverleaf. Frequent in woods. Noticed in particular on the steep shaded banks of a small creck running into Murphy's Lake.

Hepatica acutiloba DC. Sharp-lobed liverleaf. Lsually in damp rich beech and maple woods. Noticed especially in rich woods near Murphy's Lake.

Anemone cylindrica Gray. Long-fruited ancmone. On low sand ridges near the shores of Saginaw Bay and dry hills about the small lakes.

Anemone virginiana L. Tall anemone. Occasional in shaded grount. Noticed in particular near Murphy's Lake.

Anemone canadensis L. Canada anemone. Abundant in spots in damp open ground. "Common on the prairies in Akron and IViner townships." C. A. Davis.

Anemone quinquefolia L. Wood anemone. Common in shaded rich ground.

Clematis virginiana L. Virginia virgin's bower. Noticed in damp thickets and along the banks of small streams. Frequent. 
Caltha palustris L. Marsh marigold. Common in swamps, wet woods, thickets and open marshy ground.

Coptis trifolia (L.) Salisb. Gold thread. Noticed in particular in tamarack swamps about Cat Lake and Mud Lake. Probably frequent throughout.

Aquilegia canadensis L. Wild columbine. Frequent in open shaded sandy ground. Often abundant on low shaded sand ridges near the shore of Saginaw Bay and also on the islands of the prairies.

Actaea rubra (Ait.) Willd. Red baneberry. Frequent in rich woods and thickets and noticed on the islands in Akron Township.

Actaea alba (L.) Mill. White baneberry. Noticed on damp hillsides among trees near Spruce Lake.

MAGNOLIACEAE. Magnolia Family

Liriodendron tulipifera L. Whitewood. Tulip tree. "Southern part of Fremont and Watertown townships." C. A. Davis.

\section{MENISPERMACEAE. Moonseed Family}

Menispermum canadense L. Moonseed. Common in rich woods and thickets. Noticed in particular in damp open woods near Murphy's Lake. "Borders of low woodlands and marshes, Akron and Columbia townships." C. A. Davis.

\section{BERBERIDACEAE. Barberry Family}

Podophyllum peltatum L. Mandrake. May apple. Common throughout in rich shaded ground.

Caulophyllum thalictroides (L.) Michx. Pappoose root. In rich woods especially near Murphy's Lake. Probably frequent throughout.

Berberis vulgaris L. Common barberry. "Roadside in Wisner Township." C. A. Davis.

\section{LAURACEAE. Laurel Family}

Sassafras variifolium (Salisb.) Ktze. Sassafras. Not frequent in northern part of county near Saginaw Bay, but in other parts often abundant, especially on dry hills. "Dry woodlands, Watertown and Dayton townships." C. A. Davis.

Benzoin aestivale (L.) Nees. Spice bush. Noticed in particular in rich woods near Murphy's Lake and Mud Jake. Probably frequent throughout.

\section{PAPAVERACEAE. Poppy Family}

Sanguinaria canadensis I. Bloodroot. Frequent in rich woods. Noticed in particular near Murphy's Lake and Mud Lakẹ. Probably frequent throughout. 


\section{FUMARIACEAE. Fumitory Family}

Dicentra cucullaria (L.) Bernh. Dutchman's breeches. Rich shaded ground. Frequent.

Dicentra canadensis (Goldie) Walp. Squirrel corn. In rich shaded ground near Murphy's Lake. Probably frequent throughout.

Cordalis sempervirens (L.) Pers. Pale coryclalis. Dry open jlaces, especially burned over ground. Frequent.

\section{CRUCIFERAE. Mustard Family}

Alyssum alyssoides I. Yellow alyssum. Frequent as a weed along roads and in villages.

Thlaspi arvense L. Field penny-cress. Waste places about cities and villages. Frequent.

Lepidium virginicum $\mathrm{L}$. Wild peppergrass. Common as a weed along roads and about farm buildings.

Lepidium apetalum Willd. Apetalous peppergrass. Common along roads, railroads and a weed in cultivated fields.

Capsella bursa-pastoris (L.) Medic. Shepherd's purse. A common weed in all cultivated grounds.

Camelina sativa (L.) Crantz. Gold-of-pleasure. Along railroads and in waste places of cities and villages. Frequent.

Cakile edentula (Bigel.) Hook. American sea rocket. In sand along the beach of Saginaw Bay, often growing below the wave line.

Raphanus raphanistrum L. Wild radish. Jointed charlock. " Escaped in sandy places near dwellings." C. A. Davis.

Brassica arvensis (L.) Ktze. Common mustard. Charlock. A common weed in grain fields and waste places.

Brassica nigra (L.) Koch. Black mustard. "Cultivated and waste land." C. A. Davis.

Conringia orientalis (L.) Dumart. Hare's ear mustard. Along railroads and in waste places of cities and villages.

Sisymbrium officinale leiocarpum DC. Smooth podded hedge-mustard. A common weed along roads and about farm buildings.

Sisymbrium altissimum L. Tumble mustard. Noticed along the road near Murphy's Lake and in villages. Spreading.

Erysimum cheiranthoides L. Worm-seed mustarl. A weed along roads, about farm buildings and in cultivated grounds.

Radicula nasturtium-aquaticum (L.) Britten \& Renclle. True water cress. In ditches and small streams. Abundant in a small stream west of Mayville where it climbed three feet and more upon willows like a vine.

Radicula palustris (L.) Moench. Marsh cress. Frequent and often abundant in ditches and wet marshy places. 
Radicula armoracia (L.) Robinson. Horseradish. Noticed as an escape in ditches and wet places, throughout.

Dentaria diphylla Michx. Crinkle-root. In rich woods near Murphy's Lake. Probably frequent throughout.

Dentaria laciniata Muhl. Cut-leaved toothwort. In rich woods near Murphy's Lake and Mud Lake. Probably frequent throughout.

Cardamine bulbosa (Schreb.) BSP. Spring cress. In damp grassy places, especially near the small lakes. Frequent.

Cardamine douglassii (Torr.) Britton. Purple cress. Noticed in rich woods near Murphy's Lake. Probably frequent throughout.

Cardamine pennsylvanica Muhl. Pennsylvania bitter cress. Noticed in a wet open place near Quanicassee. Probably frequent throughout.

Cardamine pratensis L. Cuckoo flower. Wet low places and low banks of streams. Irequent.

A rabis lyrata L. Lyre-leaved rock cress. On sandy ridges near the shore of Saginaw Bay, and kigh hills about Murphy's Lake.

Arabis glabra (L.) Bernh. Tower mustard. Dry open or partially shaded ground. Frequent.

Arabis laevigata. (Mubl.) Poir. Smooth rock cress. "Sandy ridges and poor soil, Akron and Wisner townships." C. A. Daris.

\section{SARRACENIACEAE. Pitcher-plant Family}

Sarracenia purpurca L. Pitcher-plant. Abundant in the swamps about Cat Lake and Mud Lake.

\section{DROSERACEAE. Sundew Family}

Drosera rotundifolia L. Round-leaved sundew. Swamps and peatbogs. Frequent.

CRASSULACEAE. Orpine Family

Penthorum sedoides I. Ditch stonecrop. Common in wet places, especially along ditches.

Sedum acre L. Mossy stonecrop. Occasional on sandy ground along roads and about cemeteries.

Sedum purpureum Tausch. Live-for-ever. Frequent along roads, in cemeteries and about dwellings.

SAXIFRAGACEAE. Saxifrage Family

Tiarella cordifolia L. False miterwort. Common in rich woods, especially near Murphy's Lake.

Mitella diphylla I. Two-leaved bishop's cap. In rich woods about Murphy's Lake and Cat Lake. Probably common throughout. 
Mitella nuda L. Naked bishop's cap. In tumarack swamps near Cat Lake and Mud Lake.

Chrysosplenium americanum Schwein. Golden saxifrage. In a very wet shaded place near Murphy's Lake. Probably occurring throughout.

Parnassia caroliana Michx. Carolina grass of parnassus. Noticed by Prof. C. A. Davis in damp prairie-like ground in the northern part of Akron T'ownship.

Ribes cynosbati L. Prickly gooseberry. Very frequent in rich open or shaded ground.

Ribes oxyacunthoides I. Smooth gooseberry. Frequent in tamarack swamps about Cat Lake and Mud Lake.

Ribes floridum L'Her. Wild black currant. Common in rich wooks and thickets.

Ribes prostratum L'Her. Skunk currant. In a tamarack swamp near Cat Lake.

Ribes triste Pall. Swamp red currant. Noticed by Prof. C. A. Davis in rich woods in northern part of Akron Township.

Ribes aureum Pursh. Buffalo currant. An escape from cultivation in many places.

HAMAMELIDACEAE. Witch-hazel Family

Hamamelis virginiana L. Witch-hazel. Common especially on high hilly ground.

PLATANACEAE. Plane Tree Family

Platanus occidentalis L. Sycamore. Buttonwood. Oceasional throughout with other trees. More common near the shore of Saginaw Bay, often fringing the upper beach.

ROSACEAE. Rose Family

Physocarpus opulifolius (L.) Maxim. Nine-bark. Noticed in the vicinity of small lakes.

Spiraea salicifolia L. American meadow-swect. Common and usually in low open ground.

Spiraea tomentosa L. Hardhack. Steeple bush. "Borders of swamps, Dayton and Wells townships." C. A. Davis.

Sorbaria sorbifolia (L.) A.Br. Mountain ash spiraca. Inclined to escape from cultivation into streets and roads.

Pyrus coronaria L. American crab. Noticed in particular on the Iry banks of North Lake. "Akron Township." C. A. Davis.

Pyrus malus I. Common apple. Noticed throughout along roads and in open woods.

Pyrus arbutifolia atropurpurea (Britton) Robinson. Red chokeberry: In swamps especially about the small lakes. 
Pyrus melanocarpa (Michx.) Willd. Black chokeberry. Abundant in spots in low open ground, especially near the small lakes.

Pyrus americana (Marsh.) DC. American mountain ash. In woods near Shay's Lake and perhaps an escape.

Amelanchier canadensis (L.) Medic. Juneberry. May-cherry. Noticed in particular on high dry ground about the small lakes.

Amelanchier oblongifolia (T. \& G.) Roem. Shad bush. On low sand ridges near the shore of Saginaw Bay. "In swampy woods throughout." C. A. Daris.

Crataegus crus-galli L. Cockspur thorn. Frequent and usually in dry open ground. "One tree about a foot in diameter noted in north part of Akron Township." C. A. Davis.

Crataegus punctata Jacq. Large-fruited thorn. Frequent in woods and open ground.

Crataegus tomentosa L. Pear thorn. Pear haw. Noticed by Prof. C. A. Davis, near Unionville. Probably frequent throughout.

Fragaria virginiana Duchesne. Common strawberry. Common in damp or dry ground.

Fragaria vesca americana Porter. American wood strawberry. In rich woods along a small stream with high shaded banks near Murphy's Lake. Also frequent on the "islands."

Potentilla monspeliensis L. Rough cinquefoil. A weed in yards, fields and along roads.

Potentilla argentea L. Silvery cinquefoil. Frequent on dry sandy ground. Noticed in particular on dry hills about the small lakes.

Potentilla palustris (L.) Scop. Marsh five-finger. In very wet and swampy places especially near the small lakes.

Potentilla fruticosa L. Shrubby cinquefoil. "Moist or dry sandy soil back of Algonquin beach in Akron Township." C. A. Davis.

Potentilla anserina L. Silver weed. In damp ground near the shore of Saginaw Bay. Often very abundant. "Frequent on the sandy tracts in the prairies of Akron and Wisner townships and in moist places along the dunes of the bay. Rare inland in moist sand." C. A. Davis.

Potentilla canadensis L. Five-finger. Common in dry open ground.

Geum canadense Jacq. White avens. Common throughout in damp rich woods.

Geum virginianum L. Rough avens. "Rich woodlands and wet open grounds." C. A. Davis.

Geum strictum Ait. Yellow avens. Frequent in damp meadows and moist grassy places.

Geum rivale L. Water avens. In very wet places and wet open wonds. Noticed in particular near Cat Lake.

Rubus idaeus aculeatissimus (C. A. Mey.) Regel \& Tiling. Wild red raspherry. Common in open dry or damp shaded ground. 
Rubus occidentalis L. Black raspberry. Black caps. Frequent in damp woods and thickets.

Rubus odoratus L. Purple-flowering raspberry. In hilly grround north of Cat Lake. Not noticed elsewhere.

Rubus triflorus Richards. Dwarf raspherry. Common in wot woods and thickets.

Rubus allegheniensis Porter. High-bush blackberry. Common along fences, on dry sandy ground and in open dry woods.

Rubus nigricans Rydb. Peck's dewherry. "Borders of swam?s, Dayton Township." C. A. Davis.

Rubushispidus L. Hispid blackberry. Common in tamarackswamps and in damp open or shaded ground.

Rubus villosus Ait. Dewberry. Common in sandy open ground and on dry hills.

Agrimonia gryposcpala Wallr. Common agrimony. Occasional in woods and thickets. "Rich low woods in Columbia Township." C. A. Davis.

Agrimonia parviflora Ait. Many flowered agrimony. Columbia Township. Beech and maple woods.

Rosa acicularis Lindl. Prickly rose. "Sand dunes along Saginaw Bay." C. A. Davis.

Rosa blanda Ait. Meadow rose. Common throughout on dry or damp ground.

Rosa spinosissima L. Scotch rose. Inclined to escape from cultivation and persist. Noticed in particular in the yard of F. E. Warner near Cat Lake.

Rosa canina L. Dog rose. "Roadsides near old gardens in Columbia Township." C. A. Davis.

Rosa rubiginosa L. Sweetbrier. Frequent along roads, occasional in old fields and open dry woods.

Rosa carolina L. Swamp rose. Common in swamps and low marshy places.

Rosa humilis Marsh. Pasture rose. On high and dry ground. Noticed in particular on sides of dry hills near the small lakes.

Prunus serotina Ehrh. Wild black cherry. Common in rich ground with other trees. "Rich woods. Also in pine slashings and on dums." C. A. Davis.

Prunus virginiana L. Choke cherry. Common throughout in damp) or dry ground often on dunes. "Sand dunes in Akron and Wisner townships." C. A. Davis.

Prunus pennsyluanica L.f. Wild red cherry. Along fences. horders of dry woods and on dry hills. "Common in old pine slashings, in Indianfields and Vassar townships. Also in Watertown and Fremont townships." C. A. Davis. 
Prumus pumila L. Sand cherry. In salidy places on and near the beach of Saginaw Bay and dry hills.

Prunus cerasus L. Common sour cherry. Abundant and fast spreading along road fences and about dwellings.

Prunus americana Marsh. Wild red plum. Frequent on borders of woods and thickets. Noticed in particular in the vicinity of Murphy's Lake and North Lake.

Prunus persica (I.) Stokes. Common peach. Noticed on roadsides in several places as an escape from cultivation.

\section{LEGUMINOSAE. Pulse Family}

Gleditsia triacanthos L. Honey locust. Occasionally planted for ornament in villages, but apparently not escaping.

Trifolium arvense L. Rabbit-foot clover. Stone clover. "Noted in a single station in southwest Watertown and also near Vassar Railroad station." C. A. Davis.

Trifolium pratense L. Red clover. Common along roads, in yards and pastures.

Trifolium repens $\mathrm{L}$. White clover. Common along roads, in yards and pastures.

Trifolium hybridum L. Alsike clover. Becoming common everywhere as an escape.

Trifolium agrarium L. Hop clover. Occasional in villages and along roads.

Melilotus officinalis (L.) Lam. Yellow melilot. Occasional in villages.

Melilotus alba Desr. Sweet clover. Common in villages and along roads preferring hard clayey ground, and often a weed in cultivated fields.

Medicago sativa L. Alfalfa lucerne. Frequent in villages and occasional along roads and railroads.

Medicago lupulina L. Black medic. Common along roads and in waste places. Often a lawn weed.

Robinia pseudo-acacia I. Common locust. Planted and often escaping and persisting.

Astragalus neglectus (T'. \& G.) Sheldon. Cooper's milk vetch. "Sandy soil, section 9, Kingston Township." C. A. Davis.

Desmodium nudiflorum (L.) DC. Naked-flowered tick-trefoil. Noticed in shaded dry ground on the hills about Murphy's Lake and Spruce Lake. "Oak woods and islands in the prairies." C. A. Davis.

Desmodium grandiflorum (Walt.) DC. Pointed-leaved tick-trefoil. In rich woods especially near the small lakes. "Open dry woods and oak islands in prairies of Akron Township." C. A. Davis.

Desmodium rotundifolium (Michx.) I)C. Prostrate tick-trefoil. On the dry shaded banks of North Lake. Not noticed elsewhere. 
Desmodium naniculatum (I.) DC. Panicled tick-trefoil. ()n the dry banks of North Lake. "Oak woods and islands in the prairies." C. A. Davis.

Desmodium canadense (I.) DC. Showy tick-trefoil. ()crasional on low sand ridges near the shore of Saginaw Bay and on some of the "islands." "Sandy prairies." C. A. Davis.

Lespedeza violacea (L.) Pers. Bush clover. "Sandy and gravelly woods, Watertown Township." C. A. Davis.

Lespedeza virginica (L.) Britton. Slender bush clover. On the dry banks of North Lake. Not noticed clsewhere.

Lespedeza frutescens (T..) Britton. Wand-like bush clover. In dry hilly ground near Murphy's Lake and Spruce Lake.

Lespedeza capitata Michx. Round-headed bush clover. ()n high and dry hills about the small lakes. "Sandy ridges and flats, Akron and Columbia townships." C. A. Davis.

Lespedeza hirta (L.) Hornem. Hairy bush clover. On dry rocky hills near Spruce Lake. "Sandy ridges and flats, Akron and Columlia townships." C. A. Davis.

Vicia angustifolia (L.) Reichard. Common vetch. Along roak and railroads. Frequent.

Vicia americana Muhl. American vetch. On clry hilly ground among brush near Murphy's Lake. Not noticed elsewhere.

Vicia villosa Roth. Hairy vetch. Noticed in clover fields and along the road north of Mayville where it appeared to be a permanent cisape.

Lathyrus maritimus (I.) Bigel. Beach pea. Cecasional on the leach of Saginaw Bay.

Lathyrus palustris L. Marsh vetchling. Common in damp marshy places.

Lathyrus palustris myrtifolius (Muhl.) Gray. Myrtle-leaverl marsh pea. Along ditches and about the small lakes.

Lathyrus ochroleucus Hook. Cream-colored vetchling. Ahundint on shaded hillsides near Murphy's Lake.

Apios tuberosa Moench. Wild bean. In damp open ground and in borders of thickets. Common.

Amphicarpamonoica (I.) Ell. Hog peanut. Frequent in wools and thickets.

\section{LINACEAE. Flax Family}

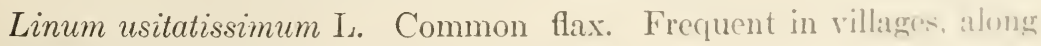
railroads, about stations and depot grounds.

Linum sulcatum Riddell. Grooved yellow flax. In dry open fromend near North Lake. Not noticed elsewhere. 


\section{OXALIDACEAE. Wood Sorrel Family-}

Oxalis stricta L. Upright yellow wood sorrel. Often along railroads, in depot grounds and waste places.

Oxalis corniculata L. Lady's sorrel. Dry or damp open ground. Often a weed in gardens and waste places.

\section{GERANIACEAE. Geranium Family}

Geranium maculatum L. Wild crane's-bill. "Burned over sandy land in the Cass River valley, Vassar Township." C. A. Davis.

Geranium bicknellii Britton. Bicknell's crane's-bill. Open woods and especially in recent clearings and burned over ground. Frequent.

\section{RUTACEAE. Rue Family}

Zanthoxylum americanum Mill. Northern prickly ash. Common in damp woods and thickets.

\section{SIMARUBACEAE. Quassia Family}

Ailanthus glandulosa Desf. Tree of heaven. Planted occasionally as an ornamental tree and often escaping.

\section{POLYGALACEAE. Milkwort Family}

Polygala pauciflora Willd. Fringed polygala. In dry sterile shaded ground. Frequent.

Polygala polygama Walt. Racemed milkwort. "Low sand ridges on the prairies and in Indianfields Township." C. A. Davis.

Polygala senega L. Seneca snakeroot. Abundant on an "island" near Bay Park. "Low sandy areas on the prairies of Akron and Wisner townships." C. A. Davis.

\section{EUPHORBIACEAE. Spurge Family}

Euphorbia polygonifolia I. Seaside spurge. Occasional in sand along the beach of Saginaw Bay.

Euphorbia preslii Guss. Upright spotted spurge. Dry open ground. Noticed particularly about depot grounds in cities and villages.

Euphorbia maculata L. Milk purslane. On roadsides in villages and along railroads. Common.

Euphorbia corollala L. Flowering spurge. Occasional on low sand ridges near the shore of Saginaw Bay, and on dry hills about the small lakes.

Euphorbia cyparissias L. Cypress spurge. Frequent in cemeteries and on sandy dry ground along roads. 


\section{ANACARDIACEAE. Cashew Family}

Rhus typhina I. Staghorn sumach. Common throughout in dry or damp ground.

Rhus glabra L. Smooth sumach. Frequent and usually on high and dry ground. Noticed in particular on the hills about ('at Lakc'.

Rhus copallina L. Dwarf sumach. Abundant on high ground in one place near North Lake. Not noticed elsewhere.

Rhus vernix $\mathrm{L}$. Poison sumach. Poison dogwood. In swampy groland throughout. Abundant in swamps near the small lakes.

Rhus toxicodendron L. Poison ivy. Poison oak. Common in dry or damp, open or shaded ground. In spots very abundant, especially on sand ridges near the shore of Saginaw Bay. Occasionally climbing trees as a vine, which form some authors designate as Rhus toxicodendron radicans (L.) Torr., climbing poison ivy.

Rhus canadensis Marsh. Fragrant sumach. Noticed by Prof. ('. A. Davis on low sand ridges in northern part of Akron Township.

\section{AQUIFOLIACEAE. Holly Family}

Ilex verticillata (L.) Gray. Winterberry. Black alder. Common in low ground and rich open woods, especially in the vicinity of the small lakes.

Nemopanthus mucronala (L.) Trel. Mountain holly. In tamarack swamps and in swampy places among willows and other shrubs, especially in the vicinity of the small lakes.

\section{CELASTRACEAE. Staff Tree Family}

Evonymus obovatus Nutt. Running strawberry bush. Frequent in rich damp woods. Noticed in particular near Murphy's Lake.

Celastrus scandens L. Climbing bittersweet. Common in woods, thickets and along fences. Known in Michigan and Western Ontario as bitter-sweet.

STAPHYLEACEAE. Bladder Nut Family

Staphylea trifolia L. American bladder nut. "Cass River valley" north of Vassar and in Tuscola Township." C. 1. 1)avis.

\section{ACERACEAE. Naple Family}

Acer spicatum Lam. Mountain maple. Common in swamps and rich open woods, especially about the small lakes.

Acer pseudo-platanus L. Sycamore maple. Occasionally planted as an ornamental tree, but not spruading.

Acer saccharum Marsh. Sugar maple. Common throughout in rich ground with other trees, often covering hilly land. 
Acer saccharum nigrum (Michx.f.) Britton. Black maple. Black sugar maple. "Frequent in Akron and Columbia townships." C. A. Davis.

Acer saccharinum L. Silver maple. Usually on borders of rich woods and along small streams. Frequent.

Acer rubrum L. Red maple. Common in rich wet ground with other trees.

Acer platanoides L. Norway maple. Occasionally planted in villages along streets and in yards, but apparently not escaping.

Acer negundo I. Box elder. Planted in villages as a street and yard tree and escaping everywhere. "Banks of Cass River near Vassar. Planted generally." C. A. Daris.

SAPINDACEAE. Soapberry Family

Aesculus hippocastanum L. Common horse-chestnut. Planted in villages as a street and lawn tree and occasionally escaping.

BALSAMINACEAE. Touch-me-not Family

Impatiens biflora Walt. Spotted touch-me-not. Very common in damp open and shaded places.

RHAMNACEAE. Buckthorn Family

Rhamnus alnifolia L'Her. Alder-leaved buckthorn. Common in swampy places, especially near the small lakes.

Ceanothus americanus L. New Jersey tea. Red-root. Common throughout on dry sandy ground. Noticed in particular on the hills about the small lakes.

\section{VITACEAE. Vine Family}

Psedera vitacea (Knerr) Greene. American woodbine. American ivy. Common in moist woods and along fences. Often cultivated as an ornamental vine.

Vitis bicolor LeConte. Summer grape. In woods or open ground. Noticed in particular on hilly ground near Cat Lake, Murphy's Lake and Spruce Lake.

Vitis vulpina L. River-bank grape. Common in woods and on dry sandy or rich open ground, along streams, and often fringing the upper beach of Saginaw Bay. Also on sand dunes.

TILIACEAE. Linden Family

Titia americana L. Basswood. Common in rich ground with other trees. 
MALVACEAE. Mallow Family

Abutilon thcophrasti Medic. Velvet leaf. Noticed along roads and as a weed in gardens and bean fields.

Althaea rosea Cav. Hollyhock. "Escaped from cultivation along moist roadsides in Fairgrove and Columbia townships." C. A. Dari...

Malva rotundifolia L. Common mallow. Cheeses. Common as a roadside and garden weed.

Malva sylvestris L. High mallow. "Millington Township by the roadside." C. A. Davis.

Malva moschata L. Musk mallow. Occasional as an escaje along roads and in old fields.

\section{HYPERICACEAE. St. John's-wort Family}

Hypericum ascyron L. Great St John's-wort. Damp open ground and on banks of streams. Frequent.

Hypericum perforatum L. Common St. John's-wort. Frequent as a weed along roads and occasional in old fields.

Hypericum punctatum Lam. Spotted St. John's-wort. Occasional in damp shaded ground, especially near the small lakes.

Hypericum prolificum L. Shrubby St. John's-wort. In dryish open woods near Murphy's Lake. Probably frequent throughout.

Hypericum kalmianum L. Kalm's St. John's-wort. Occasional in sand near the beach of Saginaw Bay. "Prairies in Akron Township." C. A. Davis.

Hypericum mutilum L. Small-flowered St. John's-wort. Frequent in low grassy ground, especially in the vicinity of the small lakes.

Hypericum canadense L. Canadian St. John's-wort. "Along the shores of the bay in Akron Township." C. A. Davis.

Hypericum virginicum L. Marsh St. John's-wort. Common, especially in low open and marshy ground about the small lakes.

\section{CISTACEAE. Rockrose Family}

Helianthemum canadense (L.?) Michx. Long-branched frostweed. In dry sandy ground near the shore of Saginaw Bay and on the hills about the small lakes.

Lechea villosa Ell. Hairy pinweed. Noticed by Prof. ('. 1. Davis in the northern part of Akron Township).

\section{VIOLACEAE. Violet Family}

Viola cucullata Ait. Marsh blue violet. Common in wet marshy ground, especially about the small lakes.

Viola sororia Willd. Woclly blue violet. Common in meadows and 
woods, and on the "islands". This and the preceding were formerly included under the name of Viola palmata cucullata Gray.

Viola fimbriatula Ait. Arrow-leaved violet. Along the railroad between Sebewaing and Akron. Probably frequent throughout in dry sandy ground.

Tiola pallens (Banks) Brainard. Northern white violet. Wet springy places and along the low banks of sharled brooks. Frequent.

Tiola blanda Willd. Sweet white violet. "Cold swamps in Wells Township." C. A. Davis.

Viola incognita Brainard. Sweet white violet. Common in rich damp open ground and woods.

Viola pubescens Ait. Downy yellow violet. In dry woods and on dry shaded hills.

Viola scabriuscula Schwein. Smooth yellow ivolet. Common in rich damp woods and thickets.

Viola canadensis L. Canada violet. Dryish rich open woods. Frequent throughout.

Viola striata Ait. Pale violet. Striped violet. Rich shaded ground. Frequent.

Viola conspersa Reichenb. American dog violet. Common in rich woods, damp shaded places, and often abundant in wet open ground.

Viola rostrata Pursh. Long-spurred violet. On shaded hillsides about Murphy's Lake. Probably frequent throughout.

Viola tricolor L. Pansy. Cultivated and inclined to escape.

\section{THYMELAEACEAE. Mezereum Family}

Dirca palustris L. Leatherwood. Moosewood. "Rich woods in Almer Township." C. A. Davis.

\section{LYTHRACEAE. Loosestrife Family}

Decodon verticillatus (L.) Ell. Water willow. Often abundant in swampy places in the vicinity of the small lakes. The beautiful little Cedar Lake is completely encircled with it.

Lythrum alatum Pursh. Wing-angled loosestrife. Frequent on prairie-like ground throughout.

\section{ONAGRACEAE. Evening Primrose Family}

Ludvigia polycarpa Short \& Peter. Many-fruited ludvigia. "Ditches and wet marshy places in prairies of Akron Township." C. A. Davis.

Ludvigia palustris (L.) Ell. Water purslanes. Abundant, when found at all, in ditches and muddy places.

Epilobium angustifolium I. Great willow herb. Common in low 
open ground or open woods. One of the recent common names is fireweed.

Epilobium molle Torr. Downy willow herb. Noticed in wet (o) un places about Cat Lake.

Epilobium densum Raf. Linear-leaved willow herb. Trecpucme in low marshy ground. Very abundant about Mind Lake.

Epilobium coloratum Muhl. Purple-leaved willow hert). "I,ow meadows and pastures throughout." C. A. Davis.

Epilobium adenocaulon Haussk. Northern willow herb. Frequent in rich damp open ground, especially about the small lakes.

Oenothera biennis L. Common evening primrose. Common in dry sandy open or shaded ground.

Circaea lutetiana L. Enchanter's nightshade. Tery common in rich woods and thickets.

Circaea alpina 1. Smaller enchanter's nightshade. In thick damp woods and thickets. Noticed in particular in tamarack swamps near Cat Lake and Murphy's Lake.

\section{HALORAGIDACEAE. Water Milfoil Family}

Myriophyllum spicatum L. Spiked water-milfoil. In shallow water on margins of small lakes. Frequent.

Myriophyllum heterophyllum. Various leaved water-milfoil. Margins of small lakes in shallow water. Frequent.

Proserpinaca palustris L. Mermaid-weed. Frequent and often ahundant in wet marshy places near the shore of Saginaw Bay and near the small lakes.

\section{ARALIACEAE. Ginseng Family}

Aralia racemosa L. Spikenard. Common in rich damp wonds. Noticed in particular in woods near Cat Lake and Murphy's Lake.

Aralia hispida Vent. Bristly sarsaparilla. Noticed in (liy poor ground on the hills near Cat Lake. Probably frequent throughout.

Aralia nudicaulis L. Wild sarsaparilla. Tery common in moist woods and thickets, and occasional in dry sandy ground.

Panax quinquefolium L. Ginseng. Not noticed, but reported hy old residents as formerly abundant.

Panax trifolium L. Dwarf ginseng. Ground-nut. "Rich moist woodlands." C. A. Davis.

\section{UMBELLIFERAE. Parsley Family}

Sanicula marilandica I. Black snakeroot. Common in rich woods and thickets.

Osmorhiza claytoni (Michx.) Clarke. Woolly sweet cicoly. On the "islands" in Akron Township. C. A. Davis. 
Osmorhiza longistylis (Torr.) DC. Smoother sweet cicely. Common in rich woods, especially near the small lakes.

Conium maculatum L. Poison hemlock. Frequent in waste places of cities and villages.

Cicuta maculata L. Water hemlock. Beaver poison. Frequent throughout in wet marshy ground, and often in open damp woods. Root said to be very poisonous.

Cicuta bulbifera L. Bulb-bearing water hemlock. Common in open wet places along the shore of Saginaw Bay and about the small lakes.

Carum carvi L. Caraway. Occasional as an escape along roads and about dwellings.

Sium cicutaefolium Schrank. Water parsnip. Common in ditches, wet and muddy places.

Cryptotaenia canadensis (I.) DC. Honewort. Very common in rich woods and thickets.

Zizia aurea (L.) Koch. Golden alexanders. Meadow-like ground. Frequent.

Taenidia integerrima (L.) Drude. Yellow pimpernel. On the "islands" in Akron Township and the dry banks of North Lake.

Thaspium aureum Nutt. Purple meadow parsnip. "Dry ground, Millington and Watertown townships." C. A. Davis.

Pastinaca sativa L. Parsnip. Frequent along roads as an escape.

Heracleum lanatum Michx. Cow Parsnip. Occasional in woods in northern part of Akron Township.

Daucus carota L. Carrot. Noticed along roads and as a frequent weed in fields.

\section{CORNACEAE. Dogwood Family}

Cornus canadensis L. Dwarf cornel. Bunch berry. In tamarack swamps about Cat Lake. "Indianfields Township in old pine slashings." C. A. Davis.

Cornus florida L. Flowering dogwood. Plentiful on the dry banks of North Lake. Not noticed elsewhere.

Cornus circinata L'Her. Round-leaved dogwood. In open woods and thickets and on hilly ground about the small lakes. "Rich low woodlands, Columbia and Fairgrove townships." C. A. Davis.

Cornus amomum Mill. Silky cornel. In wet swampy places, especially about the small lakes.

Cornus baileyi Coult \& Evans. Bailey's dogwood. "Sand dunes near Saginaw Bay." C. A. Davis.

Cornus stolonifera Michx. Red-osier dogwood. Often called red willow. Common near the shore of Saginaw Bay and occasional throughout in swampy ground. "Common in wet places, especially on the prairies of Akron and Wisner townships, where it has spread rapidly since they were drained." C. A. Davis. 
Cornus paniculata L'Her. Panicled dogwood. Common throughout on borders of woods and banks of streams.

Cornus alternifolia I.f. Alternate-leaved dogwood. Common in open damp woods, especially near the small lakes.

Nyssa sylvatica Marsh. Black gum. Pepperidge. Noticed only north of Mayville on hilly ground. Perhaps frequent throughout.

\section{ERICACEAE. Heath Family}

Chimaphila umbellata (L.) Nutt. Prince's Pine. Pipsissewa. Noticed under pines near North Lake. Probably frequent throughout.

Moneses uniflora (L.) Gray. Rich woods. Frequent. Liable to be overlooked.

Pyrola secunda L. One-sided wintergreen. In rich woods near Murphy's Lake. Probably frequent throughout.

Pyrola elliptica Nutt. Shin leaf. On shaded hilly ground near Murphy's Lake. Probably frequent throughout.

Pyrola americana Sweet. Round-leaved wintergreen. In dry shaded ground near North Lake. Probably frequent throughout.

Monotropa uniflora L. Indian pipe. Rich Woods. Frequent.

Ledum groenlandicum Oeder. Labrador tea. Abundant in a sprucetamarack swamp near Cat Lake.

Kalima polifolia Wang. Pale laurel. In a spruce-tamarack swamp near Cat Lake.

Andromeda glaucophylla Link. Bog rosemary. Abundant in a sprucetamarack swamp near Cat Lake.

Chamaedaphne calyculata (L.) Moench. Leather leaf. Abundant in a spruce-tamarack swamp near Cat Lake. "Boggy margins of lakes in Dayton and Watertown townships." C. A. Davis.

Epigaea repens L. Trailing arbutus. Mayflower. Occasional under. pines and in other shaded places. Apparently infrequent.

Gaultheria procumbens L. Teaberry. Known as wintergreen in Michigan and Western Ontario. In poor open or shaded ground throughout. Abundant and rank in sphagnum in a black spruce-tamarack swamp near Cat Lake.

Arctostaphylos uva-ursi (L.) Wang. Bearberry. Oceasional on sand ridges near the shore of Saginaw Bay.

Chiogenes hispialula (L.) T. \& C. Creeping snowberry. Moxie plum. "Cedar swamps in various parts of the county." (.. . D Iavis.

Gaylussacia baccata (Wang.) C. Koch. Black huckleberry. (ommon in poor open ground, dry open woods, and under pines. Also oftun noticed in swampy ground.

Vaccinium pennsylvanicum L. Low sweet blueberry. Common in dry and sandy shaded ground. 
Vaccinium pennsylvanicum nigrum Wood. Low black blueberry. Often found with the preceding. Berries very black.

Vaccinium corymbosum L. High-bush huckleberry. Swamp blueberry. Common in swamps especially about the small lakes. Abundant in a spruce-tamarack swamp near Cat Lake. "Abundant in a swamp in Koylton Township." C. A. Davis.

Vaccinium oxycoccus L. Small cranberry. Abundant in a sprucetamarack swamp near Cat Lake. Probably frequent throughout.

Vaccinium macrocarpon Ait. American cranberry. Noticed about Mud Lake southwest of Fostoria. "Sphagnum bogs in Dayton and Watertown townships." C. A. Davis.

\section{PRIMULACEAE. Primrose Family}

Samolus floribundus HBK. Water pimpernel. Brookweed. "Sandy banks of pools in Watertown Township." C. A. Davis.

Lysimachia quadrifolia L. Whorled loosestrife. Crosswort. On dry open ground near Murphy's Lake and North Lake. "Sandy soil in Indianfields and Vassar townships." C. A. Davis.

Lysimachia terrestris (L.) BSP. Bulb-bearing loosestrife. Frequent in damp and marshy ground. "Borders of prairies, Akron Township." C. A. Davis.

Lysimachia nummularia L. Moneywort. Occasional as an escape in the streets of villages. Often a bad weed in lawns. "Well established by roadsides near Columbia postoffice on the banks of a ditch." C. A. Davis.

Lysimachia thyrsiflora L. Tufted loosestrife. Noticed in wet ground near Mayville. Probably frequent throughout.

Steironema ciliatum (L.) Raf. Fringed loosestrife. Common throughout in rich woods and thickets.

Steironema quadriflorum (Sims) Hitchc. Prairie moneywort. Damp prairie-like open ground in northern part of county. Plentiful.

Trientalis americana (Pers.) Pursh. Star flower. Common throughout in rich woods.

\section{OLEACEAE. Olive Family}

Fraxinus americana L. White ash. Common in rich ground with other trees.

Fraxinus pennsylvanica Marsh. Red ash. Frequent in damp rich ground with other trees.

Fraxinus pennsylvanica lanceolata (Borkh.) Sarg. Green ash. Rich open woods with other trees, and along streams. Frequent.

Fraxinus nigra Marsh. Black ash. Formerly abundant in swampy ground, but becoming scarce on account of drainage and fires. Noticed 
in particular in swamps about the small lakes. "Abundant in Akron, Wisner and Gilford townships." C. A. Davis.

Syringa vulgaris I. Common lilac. Noticed as an escalpe from cultivation along roads. Infrequent.

\section{GENTIANACEAE. Gentian Family}

Gentiana crinita Froel. Fringed gentian. Noticed by Prof. C. A. Davis in prairie-like ground in the northern part of Akron Township.

Gentiana andrewsii Griseb. Closed gentian. Near Mud Lake and North Lake. Probably frequent throughout.

Halenia deflexa (Sm.) Griseb. Spurred gentian. In woorls near Mud Lake. "In swampy woods by the roadside, Fremont Township three miles north of Mayville." C. A. Davis.

Menyanthes trifoliata L. Buckbean. In very wet places about the small lakes.

\section{APOCYNACEAE. Dogbane Family}

Vinca minor L. Common periwinkle. Popularly known as myrtle. Becoming a permanent escape in the village of Akron.

A pocynum androsaemifolium L. Spreading dogbane. Frequent in dry open woods. "Sandy ridges and plains, Indianfields Township."

A pocynum cannabinum L. Indian hemp. Frequent in low ground near the small lakes. "Terraces of Cass River south of Caro." C'.A. Davis.

A pocynum cannabinum hypericifolium (Ait.) Gray. Clasping-leaved dogbane. Frequent in low open ground and the more common form.

\section{ASCLEPIADACEAE. Milkweed Family}

Asclepias tuberosa L. Butterfly-weed. Occasional throughout in dry open ground.

Asclepias purpurascens L. Purple milkweed. "Frequent on the samly. islands in the prairies of Akron and Wisner townships." ('. A. Davis.

Asclepias incarnata L. Swamp milkweed. Abundant throughout in low damp ground. Has a strong fine fiber that may yet be made useful.

Asclepias syriaca L. Common milkweed. On sand ridges near the shore of Saginaw Bay and in dry open ground throughout. Often a miserable weed in old fields and pastures.

Asclepias sullivantii Fngelm. Sullivant's milkweed. Noticerl in abundance on prairie-like ground in Akron Township, especially in the northern part. Perhaps the northern limit of the plant.

Asclepias phyitolaccoides Pursh. Poke milkweed. "(rood soil and moist places in Akron, Columbia and Fairgrove townships." C. A. Davis. 
Acerates floridana (Lam.) Hitchc. Florida milkweed. Often abundant in prairie-like ground in the northern part of Akron Township. Perhaps its northern limit.

\section{CONVOLVULACEAE. Convolvulus Family}

Convolvulus spithamaeus L. Upright bindweed. Dry sandy usually open ground. Frequent.

Convolvulus sepium L. Hedge bindweed. In damp open ground especially in the vicinity of the small lakes.

Convolvulus arvensis L. Field bindweed. Noticed as occasional in waste places about villages, and along railroads. Liable to become a bad weed.

Cuscuta gronovii Willd. Love-vine. Gronovius' dodder. In damp shaded or open ground on willows and other plants along streams and near the small lakes.

POLEMONIACEAE. Polemonium Family

Phlox divaricata L. Blue phlox. Abundant in rich woods near Murphy's Lake. Probably frequent throughout.

\section{HYDROPHYLLACEAE. Waterleaf Family}

Hydrophyllum virginianum L. Virginia waterleaf. In rich woods near Murphy's Lake. Probably frequent throughout.

\section{BORAGINACEAE. Borage Family}

Cynoglossumi officinale L. Common hound's-tongue. Along roads, in open dry woods, old fields and about dwellings.

Cynoglossum virginianum L. Wild comfrey. Common throughout in open dryish woods.

Lappula echinata Gilibert. European stickseed. Roadsides and waste places throughout.

Myosotis virginica (L.) BSP. Early scorpion-grass. "Sandy islands in prairies in Akron Township." C. A. Davis.

Lithospermum arvense L. Corn gromwell. Noticed as an occasional weed in villages and along railroads.

Lithospermum officinale L. Common gromwell. "Roadsides, Watertown Township about a mile south of Mayville." C. A. Davis.

Lithospermum gmelini (Michx.) Hitche. Hairy puccoon. On low sand ridges near the shore of Saginaw Bay and often in sand on the beach.

Lithospermum canescens (Michx.) Lehm. Hoary puccoon. Abundant on some of the islands in the northern part of Akron Township. 
Echium vulgare L. Blue-weed. Blue devil. A weed along railroads and in the waste places of cities and villages.

\section{VERBENACEAE. Vervain Family}

Verbena urticaefolia L. White vervain. Occasional along roalt and in waste places.

Verbena hastata L. Blue vervain. Often aluundant in damp plites along roads and in open damp ground.

\section{LABIATAE. Nint Family}

Teucrium canadense L. American germander. Wood sage. In rirh low open ground, especially along streams and about the small laties.

Scutellaria lateriflora I. Mad-dog skullcap. Common throughout in damp shaded ground.

Scutellaria galericulata L. Hooded willow-herb. Marsh skullcap. Frequent in swampy places, especially about the small lakes.

Marrubium vulgare I. Common horehound. Frequent as an excape about dwellings.

Agastache nepetoides (L.) Kitze. Catnip. Giant hyssop. Noticed in open rich woods near Murphy's Lake. Probably frequent throughout.

Nepeta cataria L. Catnip. Common along roads, in yards and waste places. Often a weed in cultivated grounds.

Nepeta hederacea (I.) Trevisan. Ground ivy. Gill-over-the-ground. Noticed throughout in damp shaded places and near direllings. ()ften : vicious lawn weed.

Prunella vulgaris L. Heal-all. Common throughout in dry or clamp, open or partially shaded ground.

Leonurus cardica L. Common motherwort. Common as a weed near dwellings and in waste places.

Stachys tenuifolia aspersa (Michx.) Fernald. Rough hedge nettle. "Prairies and open swamps. Occasional throughout." C. A. Dilvis.

Stachys palustris L. Hedge nettle. Marsh woundwort. Frequent in wet marshy ground, especially near the small lakes.

Monarda fistulosa L. Wild bergamot. "Dry soil, common throughout." C. A. Davis.

Monarda mollis L. Pale wild bergamot. In hilly ground and dry open woods throughout.

Satureja vulgaris (L.) Fritsch. Basil. Mountain mint. Oceasional throughout in dry open ground and dry open woods.

Pycnanthemum virginianum (I.) Durand. Virginia mountain mint. Common throughout in damp and marshy places.

Lycopus uniflorus Michx. Bugle weed. Throughout in low damp and often shaded ground. 
Lycopus americanus Muhl. Cut-leaved water horehound. Abundant throughout in damp open or shaded ground. Often producing long vine-like runners near the base of the stem.

Mentha spicata L. Spearmint. Occasional along roads and near dwellings.

Mentha piperita I. Peppermint. Frequent in damp places along roads.

Mentha arvensis canadensis (L.) Briquet. American wild mint. Frequent throughout in damp open or shaded ground.

Collinsonia canadensis L. Stone-root. Noticed in rich damp woods near Murphy's Lake. Probably frequent throughout.

\section{SOLANACEAE. Nightshade Family}

Solanum dulcamara L. Known mostly in Europe as bittersweet, in Michigan and western Ontario as nightshade. Very common throughout.

Solanum nigrum I. Common nightshade. Frequent in rich open or shaded ground and common as a garden and field weed. Ripe berries not poisonous as formerly supposed.

Physalis pruinosa I. Strawberry tomato. Noticed in sandy places in northern part of Akron Township by Prof. C. A. Davis.

Physalis heterophylla Nees. Clammy ground cherry. Frequent throughout in open sandy places.

Lycium halimifolium Mill. Common matrimony vine. Planted about dwellings as an ornamental shrub and inclined to become a permanent escape in villages and along country roads.

Datura stramonium L. Stramonium. Occasional in waste places and about villages. Seed poisonous.

Datura tatula L. Purple stramonium. Occasional in villages and waste places. Also noticed as a weed in bean fields. Seed poisonous the same as the preceding. A few years ago five children in Alpena, Michigan, were poisoned from eating the seed.

\section{SCROPHULARIACEAE. Figwort Family}

Verbascum thapsus I. Common mullein. Occasional along roads and often abundant in old fields and pastures.

Linaria vulgaris Hill. Butter and eggs. Along roads, about dwellings and occasional as a weed in old fields.

Linaria canadensis (L.) Dumont. Wild toadflax. Common on sand ridges near the shore of Saginaw Bay.

Linaria minor (I.) Desf. Small snap-dragon. A recently introduced weed along railroads and in waste places of cities and villages.

Scrophularia leporella Bicknell. Hare figwort. Noticed in rich open ground near Cat Lake. 
Chelone glabra L. Turtlehead. Snakehead. Balmony. Frequent in wet open ground, especially near the small lakes.

Mimulus ringens I. Square-stemmed monkey flower. Irequent in ditches, wet places and along small streams.

Ilysanthes dubia (L.) Barnhart. Short-stalked false pimpernel. "Wet muddy banks of small ponds in Wells and Tassar tomships." C. A. Davis.

Veronica anagallis-aquatica L. Water speedwell. "Common in the drained part of the county." C. A. Davis.

Veronica americana Schwein. American brooklime. "Brooks, II ills Township." C. A. Davis.

Veronica scutellata I. Marsh speedwell. Frequent throughout in wet and swampy places.

Veronica serpyllifolia L. Thyme-leaved speedwell. Common throughout in damp grassy places.

Veronica peregrina I. Neckweed. Purslane speedwell. A common weed in gardens and cultivated fields.

Veronica arvensis I. Corn speedwell. Occasional in edge of woods like a native plant. Noticed near Murphy's Lake.

Gerardia pedicularia L. Fern-leaved false foxglove. Occasional in dry open woods. Noticed on hilly ground near Murphy's Lake.

Gerardia paupercula (Gray) Britton. Small-flowered gerardia. Occasional in damp ground near the small lakes. "Moist sandy soil, Wells Township. Also shores of Saginaw Bay." C. A. Davis.

Castilleja coccinea (L.) Spreng. Scarlet painted cup. Noticed by Prof. C. A. Davis in prairie-like ground in northern part of Akron Township.

Melampyrum lineare Lam. Cow wheat. Frequent in dry shaded ground, especially under pines. Noticed in particular in dry shaded ground about North Lake.

Pedicularis canadensis L. Common lousewort. Woods betony. Frequent in shaded ground.

Pedicularis lanceolata Michx. Swamp lousewort. Notieed on a number of the "islands" in Akron Township.

\section{LENTIBULARIACEAE. Bladderwort Family}

Utricularia vulgaris americana Gray. C'ommon American btadilewort. Ponds, small lakes, and slow streams. Frequent.

Utriculciria intermedia Hayne. Flat-leaved bladderwort. Very wet places, usually in water. Frequent.

\section{OROBANCHACEAE. Broom-rape Family}

Epifagus virginiana (I.) Bart. Beech-drops. Noticed under heeches near North Lake. Probably frecuent throughout. 


\section{BIGNONIACEAE. Bignonia Family}

Catalpa bignonioides Walt. Catalpa. Indian bean. Occasionally planted in villages but apparently not escaping.

\section{PHRYMACEAE. Lopseed Family}

Phryma leptostachya L. Lopseed. Noticed in damp rich woods near Murphy's Iake. Probably frequent throughout.

\section{PLANTAGINACEAE. Plantain Family}

Plantago major L. Common plantain. Common near dwellings, and often in fields.

Plantago rugelii. Rugel's plantain. Common along roads, in old fields and pastures.

Plantago lancenlata I. English plantain. A recent common name is buckhorn. A common weed along roads, in lawns, old fields, meadows and pastures.

RUBIACEAE. Madder Family

Galium aparine L. Goose grass. Clearers. In shaded ground throughout.

Galium circaezans Michx. Wild liquorice. Frequent throughout in rich woods.

Galium boreale L. Northern bedstraw. Common on the "islands" in Akron Township and frequent throughout.

Galium trifidum L. Small bedstraw. Frequent in swamps about the small lakes.

Galium tinctorium L. Stiff marsh bedstraw. Frequent throughout in damp and marshy open places.

Galium asprellum Michx. Rough bedstraw. Common in damp bushy places, especially about the small lakes.

Galium triflorum Michx. Sweet-scented bedstraw. Common in rich but dryish woods.

Mitchella repens L. Partridge berry. Frequent throughout in dry woods, especially under pines.

Cephalanthus occidentalis L. Buttonbush. Common in swamps, wet places, about small ponds, and along sluggish streams.

\section{CAPRIFOLIACEAE. Honeysuckle Family}

Diervilla lonicera Mill. Bush honeysuckle. Frequent in dry woods and dry open ground. Noticed especially on dry hills about Cat Lake and Spruce Lake.

Lonicera canadensis Marsh. American fly honeysuckle. Noticed 
in particular in rich roods near Murphy's Lake. Probably common throughout.

Lonicera oblongifolia (Goldie) Hook. Swamp fly honey-uckle. Plentiful in the swamps about Cat Lake. Probably fromont thromelout.

Lonicera glaucescens Rydb. Douglas honegisuckle. Frepuent throughout and usually on hilly, dry or sandy grommel.

Lonicera dioica L. Claucous honeysuckle. "Rich low gromme." C. A. Davis.

Linnaea borealis americana (Forbes) Rehder. Twin-flowrr. Ihindant in the tamarack swamps about Cat Lake.

Triosteum aurentiacum Bicknell. Searlet-fruited horse gentiun. Occasional on the "islands" in Akron Township.

Viburnum opulus americanum (Mill.) Ait. Cranberry-tree. Highbush cranberry. Occasional in the edge of rich woods and along small streams, especially near the small lakes.

Viburnum acerifolium L. Arrow-wood. Dockmackie. On dry hills. especially about Cat Lake, Murphy's Lake and spruce Lake.

Viburnum pubescens (Ait.) Pursh. Downy arrow-wood. Noticed in dry ground near Spruce Lake.

Viburnum cassinoides I. Withe-rod. In damp open ground near ('ut Lake.

Viburnum lentago I. Nannyberry. Sweet viburnumi. Throughout in rich open woods and along the banks of small streams.

Sambucus canadensis L. Common elder. Throughout in rich open and shaded places.

Sambucus racemosa L. Red-berried elder. Occasional in dimp rich woods. Noticed in particular in rich woods near Murphy"s Iatie.

VALERIANACEAE. Valerian Family

Valeriana uliginosa (T.\& G.) Rydlb. Swamp valerian. "Banks, colll swamps in Dayton Township." C. A. Davis.

\section{DIPSACACEAE. Teazel Family}

Dipsacus sylvestris L. Wild teasel. A few specimens moticod along the road near the village of Akron. "Beroming common in Tuseola County as a weed." C. A. Davis.

\section{CUCURBITACEAE. Gourd Family}

Sicyos angulatus I. One-seeded bur cucumber. Oerasional at a weed in and about cities and villages.

Echinocystis lobata (Michx.) (T. \& (A.) Wild bal-im-apy)le. Notieed as an occasional escape in villages, and waste places. 
CAMPANULACEAE. Bluebell Family

Campanula rapunculoides I. Creeping bellflower. Along the road near Mayville. An escape and apparently rare.

Campanula americana I. Tall bellflower. In rich woods near Murphy's Lake. Probably frequent throughout.

Campanula rotundifolia L. Harebell. Bluebell. On sand ridges near the shore of Saginaw Bay.

Campanula aparinoides Pursh. Marsh bellflower. Common throughout in wet grassy ground.

\section{LOBELIACEAE. Lobelia Family}

Lobelia cardinalis L. Cardinal flower. In a swampy open place near Cat Lake. Probably frequent throughout.

Lobelia siphilitica L. Great lobelia. Frequent in low wet ground, especially in the vicinity of the small lakes.

Lobelia spicata Lam. Pale spiked lobelia. Common in prairie-like ground, especially in the northern part of Akron Township.

Lobelia kalmii L. Brook lobelia. Noticed by Prof. C. A. Davis in the northern part of Akron Township.

Lobelia inflata L. Indian tobacco. Noticed as occasional along roads and in old fields.

\section{COMPOSITAE. Composite Family}

Ternonia illinoensis Gleason. Drummond's ironweed. Noticed in prairie-like ground in the southern part of Akron Township by Prof. C. A. Davis. Perhaps the northern limit at least for Michigan.

Eupatorium purpureum L. Joe-pye weed. Trumpet weed. Common in marshy or swampy places, especially in the vicinity of the small lakes. Often in rich woods where the plant is usually much larger and the flowers much paler than in the following variety.

Eupatorium purpureum maculatum (L.) Darl. Spotted Joe-pye weed. Frequent. Generally shorter and in wetter and more open places than the preceding species.

Eupatorium perfoliatum L. Thoroughwort. Boneset. Very common in damp or wet open ground.

Eupatorium urticaefolium Reichard. White snakeroot. Frequent on the "islands" and in rich woods, especially near the small lakes.

Liatris cylindracea Michx. Cylindric blazing star. "Sandy and gravelly ridges in the Cass River valley." C. A. Davis.

Liatris spicata (L.) Willd. Dense button snakeroot. Gay-feather. Often abundant on prairie-like ground in the northern part of Akron Township. "Abundant on the prairies of Akron and Wisner townships and on the sandy flats and borders of oak islands." C. A. Davis. 
Solidago caesia L. Blue-stemmed goldenrod. Common in rich woods, especially near the small lakes.

Solidago latifolia L. Broad-leaved goldenrod. In rich woods along a small stream with high shaded banks. Near Murphy's Lake. Also noticed on the low "islands" in Akron and Wisner townships by Prof. C. A. Davis.

Solidago hispida Muhl. Hairy goldenrod. Noticed on dry hilly ground near the small lakes. Probably frequent throughout.

Solidago uliginosa Nutt. Bog goldenrod. In wet boggy ground about Mud Lake. Apparently not common.

Solidago patula Muhl. Rough-leaved goldenrod. In shaded swampy places about Cat Lake and Mud Lake. "Open swamps and low ground throughout." C. A. Davis.

Solidago juncea Ait. Early goldenrod. Common throughout in dry" open or shaded ground. "Common in sandy soil, especially in the Cas: River valley." C. A. Davis.

Solidago ulmifolia Muhl. Elm-leaved goldenrod. "Swampy woods in Columbia and Fairgrove townships." C. A. Davis.

Solidago rugosa Mill. Wrinkle-leaved goldenrod. Common along roads and in open dry places. "Dry sandy soil throughout the county." C. A. Davis.

Solidago nemoralis Ait. Gray goldenrod. Field goldenrod. On dry hilly ground near Fostoria. "Abundant in dry sandy soil, especially in the old pine lands in the central and southern parts of the county." C. A. Davis.

Solidago canadensis L. Canada goldenrod. In rich open ground. open woods and thickets. Common and often abundant.

Solidago altissima L. Tall goldenrod. Common throughout in rich open ground.

Solidago serotina Ait. Late goldenrod. Frequent throughout on borders of woods and thickets, usually in rich ground.

Solidago ohioensis Riddell. Ohio Goldenrod. Often abundant in prairie-like ground in Akron Township. "Abundant on the wet parts of prairies in Akron and Wisner townships." C. A. Daris.

Solidago riddellii Frank. Riddell's goldenrod. "Common on the prairies of Akron Township." C. A. Davis.

Solidago graminifolia (L.) Salisb. Bushy goldenrod. Very common in moist open ground and often in wet sand on and near the heach of Saginaw Bay.

Aster divaricatus L. White wood aster. "Woods. Common." C. A. Davis.

Aster macrophyllus L. Large-leaved aster. Common throughout in dryish open woods and thickets.

Aster novae-angliae L. New England aster. Occasional in damp ground along roads. 
Aster azureus Lindl. Sky-blue aster. In open dry woods near Fostoria. Plentiful.

Aster cordifolius L. Common blue wood aster. In rich woods near the small lakes.

Aster sagittifolius Wedemeyer. Arrow-leaved aster. Noticed by Prof. C. A. Davis in northern part of Akron Township.

Aster laevis L. Smooth aster. In dry hilly and shaded ground near the small lakes.

Aster ericoides L. White heath aster. Noticed by C. A. Davis in dry ground.

Aster lateriflorus (L.) Britton. Calico aster. Common throughout along roads, on borders of woods and in old fields.

Aster tradescanti L. Tradescant's aster. Common in low wet open ground near the small lakes.

Aster paniculatus Lam. Panicled aster. Common in woods and thickets.

Aster junceus Ait. Rush aster. In wet boggy ground about Mud Lake. Probably frequent throughout.

Aster puniceus L. Red-stalk aster. In damp open woods about Mud Lake. "Swamps common." C. A. Davis.

Aster umbellatus Mill. Tall flat-top white aster. Common throughout in damp thickets.

Erigeron pulchellus Michx. Robin's plantain. "Often abundant on sandy islands in the prairies of Akron and Wisner townships." C. A. Davis.

Erigeron philadelphicus L. Philadelphia fleabane. Field daisy. Common throughout along roads and in fields. Often abundant in hay fields.

Erigeron annuus (I.) Pers. Sweet scabious. Common throughout in fields and waste places. Often abundant in hay fields.

Erigeron ramosus (Walt.) BSP. Daisy fleabane. Frequent and usually in dry ground, along roads and in fields.

Erigeron canadensis L. Horse-weed. Common as a weed in gardens, fields, waste places, and along roads.

Antennaria canadensis Greene. Canadian cat's-foot. Occasional in mats on sand ridges near the shore of Saginaw Bay and in dry open ground throughout.

Antennaria fallax Greene. Tall cat's-foot. Frequent in dry open woods and often on open sandy ground.

Antennaria neglecta Greene. Field cat's-foot. Noticed in old dry fields and on border of prairie-like ground in Akron Township.

Anaphalis margaritacea (L.) B. \& H. Pearly everlasting. Occasional in poor ground along roads and in dry open woods. 
Gnaphalium polycephalum Michx. Sweet balsam. Very abunclant along roads, in dry fields, and on hilly ground about the sma!l lake's.

Gnaphatium decurrens Ives. Clammy everlasting. Irequent throughout in dry poor ground, often growing with the preceding.

Gnaphalium uliginosum L. Low cudweed. Frequent and in spots very abundant in old fields and pastures.

Gnaphatium purpureum L. Purplish cudweed. Plentiful in dry poor open ground just north of Mud Lake. Not noticed elsewhere.

Inula helenium L. Elecampane. Frequent and often abundant along roads, in old fields, pastures, and oecasional on the border of dry open woods.

Silphium terebinthinaceum Jacq. I'rairie dock. Noticed as common on and near the "islands" in Akron and Wisner townships. Uften on roadsicles and a weed in fields. Probably its northern limit in Michignn. Ambrosia trifida I. Great ragweed. Oecasional in villages and waste places.

Ambrosia artemisiifolia Is. Common ragweed. Everrwhere as a weed along roads and in cultivated fields.

Xanthium canadense Miil. American cocklebur. Common in dimp places along roads and in villages.

Rudbeckia hirta L. Yellow daisy. Black-eyed susan. Frequent throughout in dry open ground, but not noticed anywhere as abundant.

Radbeckia laciniata L. Tall cone-flower. "Open swamps. Frequent." C. A. Davis.

Helianthus annuus L. Common sunflower. Occasional as an escape in villages.

Helianthus giganteus L. Tall sunflower. Noticed in damp open ground near Murphy's Lake. "Common on the prairies and frequent on borders of swamps elsewhere." C. A. Davis.

Helianthus divaricatus L. Rough sunflower. Frequent and often abundant throughout in dry open woods.

Helianthus strumosus L. Pale-leaved wood sunflower. Noticed on or near the banks of Murphy's Lake. Apparently not common.

Helianthus decapetalus L. Thin-leaved sunflower. "Frequent in Wells and Dayton townships." C. A. Davis.

Helianthus tuberosus L. Jerusalem artichoke. Noticed only in cultivation.

Bidens frondosa L. Beggar-ticks. (Common as a weed in damp ground and often in cultivated fields.

Bidens comosa (Gray) Wiegand. Leafy-bracted tickseed. In damp ground, especially in the vicinity of the small lakes.

Bidens connata Muhl. Purple-stemmed swamp beggitr-ticks. Frequent throughout in ditehes and wet places. 
Bidens cernua L. Stick-tight. Common in wet open places, especially near the small lakes.

Bidens laevis (L.) BSP. Larger bur marigold. Common in swampy open places about the small lakes.

Bidens trichosperma tenuiloba (Gray) Britton. Tall tickseed sunflower. Occasional in swampy places, especially near the small lakes. "Marshes throughout the county." C. A. Davis.

Helenium autumnale L. Sneezeweed. False sunflower. Occasional in wet marshy ground, especially near the small lakes.

Achillea millefolium L. Common yarrow. Milfoil. Common everywhere as a weed in dryish ground.

Anthemis cotula L. May-weed. Dog fennel. Common along roads and about dwellings.

Chrysanthemum leucanthemum pinnatifidum Lecoq \& Lamotte. Oxeye daisy. White daisy. Marguerite. Whiteweed. Occasional along roads, in fields and villages. Not noticed as a bad weed.

Chrysanthemum balsamita tanacetoides Boiss. Costmary. Mint geranium. An escape from cultivation to roads and near-by fields. Frequent and well established.

Tanacetum vulgare L. Common tansy. Frequent as an escape to roadsides and well established.

Artemisia caudata Michx. Tall wormwood. On sand ridges and often in sand near and on the beach of Saginaw Bay.

Artemisia abrotanum L. Old Man. Southernwood. Noticed as persisting in old yards, but apparently not escaping.

Artemisia biennis Willd. Biennial wormwood. Noticed as an occasional weed in villages and depot grounds.

Artemisia absinthium L. Wormwood. Absinthe. Noticed as an escape to roadsides near Mayville.

Erechtites hieracifolia (L.) Raf. Fireweed. Frequent throughout in moist woods and open places. The common name fireweed has also recently been given to Epilobium angustifolium L.

Cacalia tuberosa Nutt. Tuberous Indian plantain. Plentiful from near Quanicassee to Sebewaing in Huron County and even farther east. "Abundant in moist prairies in Akron and Wisner townships." C. A. Davis.

Senecio aureus I. Golden ragwort. Noticed in a wet marshy place near Murphy's Lake. Probably frequent throughout.

Senecio balsamitae Muhl. Balsam groundsel. Often very abundant covering the prairie-like ground with a golden mantle in the northern part of Akron 'Township. "Very abunclant on the sandy 'islands' in the prairies and along the moist slopes of dunes in Aliron and Wisner townships. The sandy islands often covered with the bright yellow blossoms of this form during the last of May and early June." C. A. Davis. 
Arctium minus Bernh. Common burdock. Common as a weed about dwellings and in cultivated grounds. Also occasional in open woods and along streams.

Cirsium lanceolatum (L.) Hill. Common thistle. Bull thistle. Frequent on roadsides and in pastures.

Cirsium discolor (Muhl.). Spreng. Field thistle. "Cass Rivor valley in sandy and gravelly soil." C. A. Davis.

Cirsium muticum Michx. Swamp thistle. Frequent throughout in low swampy places.

Cirsium arvense (L.) Scop. Canada thistle. Frequent throughout. Apparently not as vicious a weed here as in Sanilac and Huron counties.

Cichorium intybus L. Common chicory. Occasional on roadsides and in villages.

Krigia virginica (L.) Willd. Carolina dwarf dandelion. "Low sand ridges in the prairies of Akron Township." C. A. Davis.

Krigia amplexicaulis Nutt. Cynthia. Virginia goat's beard. "Sandy soil in prairies of Akron Township." C. A. Davis.

Tragopogon porrifolius L. Salsify. Oyster-plant. Frequent in villages, along roads and railroads.

Tragopogon pratensis L. Goat's beard. Noticed as a weed about Mayville. Often plentiful along railroads and in waste places of cities and villages.

Taraxacum officinale Weber. Common dandelion. Common everywhere in cultivated ground, lawns and pastures.

Sonchus arvensis L. Field sow thistle. Occasional about railway stations, depot grounds, and along railroads.

Sonchus oleraceus I. Common sow thistle. As a weed along roads, in villages, gardens and fields.

Sonchus asper (L.) Hill. Spiny-leaved sow thistle. As a weed in villages, gardens, cultivated fields and about dwellings.

Lactuca scariola integrata Gren. \& Godr. Prickly lettuce. ('ommon along roads and in waste places.

Lactuca canadensis L. Wild lettuce. Frequent in rich damp ground, especially on borders of and in open woods and thickets.

Lactuca hirsuta Muhl. Hairy wood lettuce. "Sandy soil near Caro."

C. A. Davis.

Lactuca spicata (Lam.) Hitche. Tall blue lettuce. Frequent in low ground and rich open woods.

Prenanthes alba L. White lettuce. Rattlemake-root. Frequent throughout in rich woods and thickets.

Prenanthes altissima I. Tall white lettuce. In damp ground near Cat Lake. Probably frequent throughout.

Hieracium venosum I. Rattlesnake-weed. "Sandy woodlands, Indianfields and Vassar tornships." C. A. Davis. 
Hieracium longipilum Torr. Long-bearded hawkweed. "Abundant on some of the older dune ridges near and south of Bay Park. Not seen elsewhere." C. A. Daris.

Hieracium canadense Michx. Canada hawkweed. Along the road east of Fostoria. Apparently infrequent. 
I N D E X. 



\section{N D E X.}

A.

Absinthe, wormwood

Aceracea

Adder's mouth.

Adder's Tongue Family

Aizoacer

Alder (Birch Family)

Alder (Holly Family)

Alfalfa .

Alismaceis

Alyssum

Amaranth Family

Amaranthaceæ. .

Amaryllidaceæ.

Amaryllis Family

Amacardiaceæ .

Anemone

Angelica

Apocynacea

Apple

Aquifoliacex

Aracex .

Araliaces

Arbor vita

Arbutus.

Alethusa

Arist olochiacex

Arrow Grass Family

A rrowhead

Arrowwood

Artichoke.

Arum Family

Ascelepiadaceæ.

Ash

Ash (mominain)

Ash, prickly (Rue Family)

Asparagus

Aspen.

Aster

Avens.

72. 121-2. Ifta 121

$53,111,17,201-31$.

1., in, 1800 (1,

11 1911

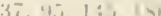

$93.1117 \quad 1.3=11$

51,1150

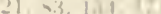

11. 1031 14: 13

$11.971 \%$

$11,47,117$ is

$1-12$

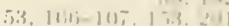

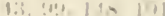

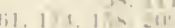

13. I10: bil in

$3,107,1004$

311, se 141 is

5- $110, \cdots 2$

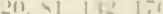

$541,112,150.21 \%$

20. $\times 1,13,1710=$

$21 \times 1+1 \%$

21 4. $131 \%$

(1) $19 x-1$

(1). 4) । il in

6. 11 is sin in

(il) lit 119 tin 21

is $11 \%$ 1 11 1\%

(2)

36. 94 is: is

(i!) - $-01,120,102,217210$

(11) lail in in.

I3.

Balsam

Balsam apple

Balsam, groundsel

Balsam, sweet (Composite Family)

Balsaminaceæ.

Baneberry.

Barberry Family

Basil, field

Basswond.

Beach pea.

Beach plants along Huron Shore

Bean, Indian

Bean, wils]

Bearberry

Beard tongue

Bedst raw

Beach drops

Beech Family

Beggars lice

Beggar ticks

Bellflower

Bellwort

Berberidacex

Bergamot

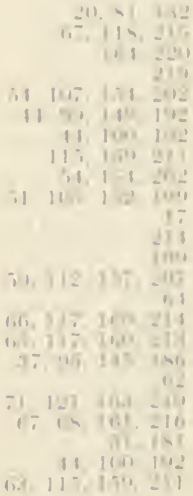


Betulacese $37,94-95,145,185-186$

Bibliography of $C$. $K$. Dodge

Bignonia Family.

Bignoniacea.

Bilberry

Bindweed.

Bindweed (Buckwheat Family).

Biography of C. K. Dodge.

$40,97,146,188$

Birch Family ..

Birthwort Family.

Bishop's cap

Bitternut

Bittersweet (Nightshade Family)

$47,102,150,194$

Bittersweet (Staff Tree Family).

Black alder (Holly Family) .

Blackberry

Black-ered susan.

$50,104,152,197$

Black gras,

$71,121,163,219$

Bladdernut Family.

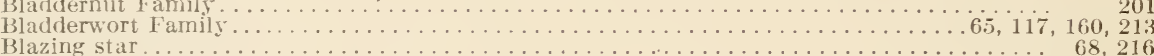

Blephilia

Bloodroot

Blue beach

Bluebell Family.

$44,100,192$

Blueberry

Blue coliosh

Blue weed

Boneset

Borage Family.

Boraginaces

Bouncing bet .

Box eller (Maple Family).

Brake

Brookline

Broom-rape Family.

Buckbean

Buckthorn Family.

Buckwheat Family.

Buffalo-berry

Bugleweed

Bug soed

Bulrush

Burdock

Bur-marigoli

Bur-reed Family.

Butter-and-eggs

Bi:t tercup

Butterfly weed .

Butternut

Butterwort

Button-busli.

Button-wood .

Cactus Family

Calamint

Calla, wilis.

Callit richacest.

Calypso

Campanulaceæ

Campion

Cancer root

('aper Family

('apparidace

('aprifoliaceæ

('araway

(ardinal flower

('arpetweed Family.

Ciarrot

('aryophyllaces

Cashew Family.

('atalpa.

('atchifly.

('atnip

('at's-foot.

('at-tail Family

('ellar

Celastracez.

('elery

('llarlock

('lienopodiaceæ

90,18 
Chess

$21,85,137,17$

Chestnut

Chickweed

Chippewa County, annotated list of plants in

botanical survey of

habitats of

surface conditions of

Cistacere.

(

Chokeberry

Christmas green

('icily .

Cincuefoil

(leavers.

Glintonia .

Clover.

('ockle

('ocklebuir

Cohosh, blue

Coltsfoot

Columbine

Comfrey.

Compositæ

Composite Fanily

Cone-flower

Convolvulaceæ

Convolvulus Family

Coral-root

Cornaceæ.

Cornel

Cornspurry

Corydalis

Costmary

Cotton-grass.

Cotton-grass, Alpine.

Cottonwood

Cowlierb

Cow wheat

Crab

Cranberry

Cranberry-tree

Cranesbill

Crassaulacea

Cress

Crinkleroot

Crowberry Family

Crowfoot Family

Cruciferæ.

Cuckoo flower

Cucurbitaceæ

Cucumber-bur

Cucumber root, Indian

Cudweerl

Currant

Cyperacea

Cystopteris.

$\ldots \ldots \ldots \ldots \ldots \ldots$

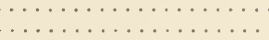

$68-74,11 ! 1-123,11 ; 1-16(1,211$
$68-74,11 !-123,16 j-11 ; 4,211$

$121,16.3,218$

ii $2,111,2,2$

5. $111,1.51 \%, 201,-21$

sis. 111,130

$11,1 \%, 1,7$,

7.2. $12111 \% 3$

$26,2,176$

3ii, $\mathrm{M}$

- M.

(ji, $117,1,9$

fi(), 113. 15is

ii, 114.

iथ, 1114,

$16,101,1 ; 0$

$14,45,16,10(2,101,1414143$

$42,14,9 ! 1-10(1,11,-11 ! 1,101$

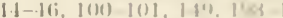

Daisy

Dandelion

Davis, Prof. C. A., work of in Tuscola Count

Deer-hair

Dewberry . .

Dioscoreacea

Dioseraceæ

Dipsacacer

Dock

Dock, prairie (Composite Family)

Dodge, Charles Keene, biblingraphy of

Dogbane Family.

biography of

Dog fennel (Maywred)

Dogwood Family

Dragon's mouth

Drop-seed

Duckweed Fanily

Dutchman's breeches.

(i) 104,172

11i. 1(1). 171)

311. $41,111 \%$

(i1. 111 lin

ii, 1,1, 16.3 20.

$\ldots \ldots \ldots$

(i)

14. 160,1410

Elæagnaceæ

Flder, box (Maple Family)

Elder 
Elecampane

Empetracea

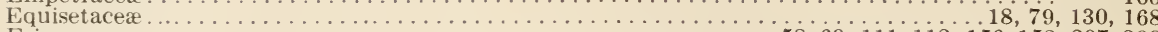

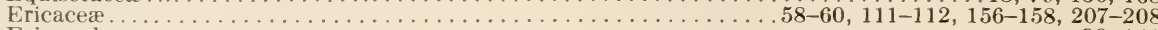

Eriocaulaceæ

30,141

Euphorbiacea

$52-53,106,200$

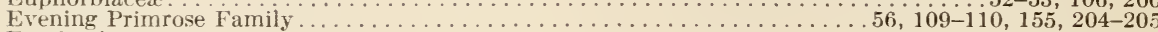

Everlasting.

F.

Fagaceæ

$37,95,145,186$

False flax

45,100

Fern Family

Feverfew

Figwort Fanily

Fireweed (Composite Family)

(Evening Primrose Family) .

Five finger

Flag

Flax Family

Fleabane

Flowering Fern Family

Fox-glove, false.

Fox-tail grass.

Frogs Bit Family

Frostweed

Fumariacez

Fumitory Family

G.

Gentian Family

Gentian, horse (Honeysuclie Family)

Gentianaceæ

Geraniaceæ

Geranium Family.

Gerardia

Germander

Ginseng Family . .

Goat's beard

Golden alexanders

Goldenrod

Golden seal

Gold-of-pleasure

Goldthread

Gooseberry

Goosefoot Family

Goose grass

Gourd Family.

Gramineæ

Grave

Grape fern (Adders's Tongue Family)

Grass Family.

Grass-of-parnassus

Grass-pink

Greenbriar

Gromwell .

Ground cherry

Ground hemlock

Ground ivy . .

Ground pine.

Groundsel . .

Gun-plant

$61,113-114,158,209$

$61,113-114,158,209$ $52,106,200$ $52,106,200$ $65,116,213$

$57,110,155,205$ $73,122,221$ 206

$43,99,148,192$ $47,102,19$ $40,97,147,18$ ? 66,214

$67,118,215$

$21-25,83-86,134-137,171-17$ $.54,108,202$

$21-25,83-86,134-137,171-17$ $47,102,150,195$

$34,92,142,183$

32,182

$62,114,210$

$64,116,159,212$

80,16 ?

$63,115,159,211$

$19,80,130-131,169$

$72,122,164,220$ 68,11 ?

H

Haloragidacer

Hamamelidacea

$56-57,110,205$

$47,19.5$

Hardhack

$102,19:$

Harebell .

Hare figwort

Hare's-tail

Haw

Hawkweed .

Hazelnut

Heal-all

Heath Family.

Heather, false

Heliotrope

Hemlork (Pine Family)

IIemlock, poison (Parsley Family)

$68,118,161,216$

159,212

$87,138,176$

$74,123,164,222$

$37,94,145,185$

159,211

$58-60,111-112,156-158,207-208$

$55,10 \mathrm{~S}$

$20,81,132,170$

$57,141,156,206$ 
Hemp (Nettle Family)

Hemp, Indian (Dogbane Family)

Henbane.

Herb robert

Hickory .

Holly Family

Hollyhock

Honewort

Honeysuckle Fainily

Hop.

Horehound

Ilorehound, cut-leaved, water

Horse-chestnut

Horseradish

Horsetail Fainily

Horseweerl

Hound's tongue

Houstonia .

Huckleberry .

Hydrocharitace:

Hydrophyllace

Hypericacea.

Iridaced

Iris . .

Ironweed, drummouds

Ironwood .

Indian bean

Indian cucumber root

Indian hemp

Indian pipe.

Indian plantain (Composite Family)

Indian tobacco

Indian turnip.

$3: 1,12,112,14=-10$ $3: 3,92,112,142$ in

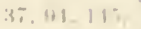

$3: 291-11$

-39. 112 1:1,

$311,411,|1|$ is

J.

Jack-in-the-pulpit

Jerusalem oak

Joe-pye weed

Jointweed

Juglandacea .

Juncaceæ.

Juncaginace'

Juneberry

Juniper

Knotgrass

Knotweed

Labiatæ

Labrador tea

Lady's slipper

Lady's thumb.

Lady's tresses

Lake Huron shore, botanical survey of

land and surface near

Lamb's quarters.

Larch, American

Lauraceæ

Laurel Family.

Laurel, (Heath Family)

Leather leaf

Leatherwood

Leek, wild.

Leguminosæ

Lemnaceæ

Lentibulariaceæ

Letters of transmittal

Lettuce

Iilac.

Liliaceæ

Lily Family

Linaceæ

Linden Family

Liquorice.

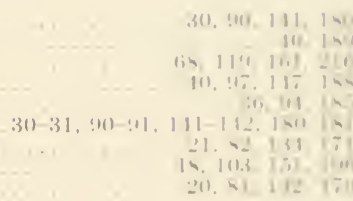

.

.

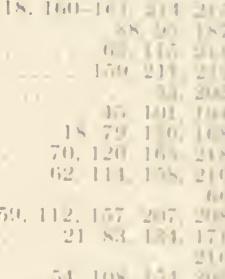


Live-for-ever

Page

Liver leaf.

$46,101,150,194$

Lizard's tail.

$43,99,148,191$

Lobelia Family.

Lobeliaceæ.

$68,119,161,216$

Locust

$68,119,161,216$

Locust, honey

51,198

Loosestrife Fam

Loosestrife (Primrose Family)

Lopseed . .

$60,113,158,208$

Loranthacem.

Loranthace

39,96

Love-vine.

65,213

Lupine.

Lycopodiace .

$19,80,130-131,169$

Lythraceæ.

M.

Madder Family

Magnolia Family

Magnoliacex

Maiden-hair fern

. 192

Mallow Family.

$17,78,129,167$

IIandrake.

Malvaceæ

Maple Family

Mare's tail (Water milfoil Family)

$54,108,154,203$

$54,108,154,203$

Marsh elder.

$53,107,153,201-202$

Marsh marigold .

Matrimony vine

May apple

May-cherry.

May-weed

Meadow rue

Meadow-sweet

Melilot

-1, 1121

Ienispermacex

Nermaid weed

Mezereum Family

Milfoil, water, Family

$43,99,148,192$
$\cdots .64,116,212$

$64,116,212$

$48,103,151,196$

$71,121,163,220$

$43,99,148,191$

$48,102,150,195$

Milkweed Tamily

$61,114,209-210$

Milkwort Family

Mint Family

$52,106,153,200$

Mistlet oe Family

$63,115-116,158-159,211-212$

Miterwort

Monkey flower

17,191

iloneywort..

$64,116,159,213$
$\ldots \ldots \ldots, 60,208$

Moonseed.

Iloose-wood

Motherwort

Mountain ash

192

$56,10 !), 204$

Moxie plum

$63,115,211$

Mugwort...

207

Mullein

Mullein pink

88,190

Mumulus

Mustard

64

Myricaceæ

N.

Nanny berry

$67,118,161,215$

Najadaceæ.

$21,82,133-134,170$

Nettle, hemp

$63,115,159,211$

Nettle Family

$38,95,146,187$

New Jersey tea.

Nightshade Family

$63-64,116,159,212$

Nightshade, enchanter's (Evening Primrose Family)

$110,15.5,205$

Nine-bark.

Nipple-wort

$47,102,150,195$

Nutgrass.

Nymphæaceæ

O.

Oak (Beech Family)

Oat.

Oats, water

$37,38,95,145,186$

Oleaceæ

$84-85,136,174$

Oleaster Family

$22,136,173$

Olive Family.

$60-61,113,158,208$

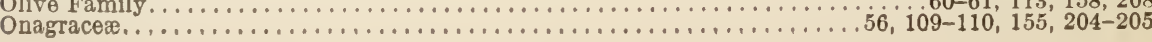

$60-61,113,158,208$ 
Ophioglossacer.

Orache.

Orchidaceg

18. $73,130.16 \mathrm{n}$

Orchis Family.

Orobanchacea.

Orpine Family.

Osage orange.

Osmundacea

Oyster plant

Oxalidaceæ.

Ox-eye daisy

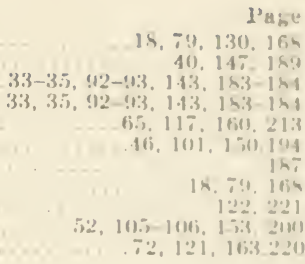

Pansy.

Papaveracea

1. 1009.102

Papoose root

14. 14:

Parsley Family.

Partridge berry

Parsnip.

Peach.

$57-5 x, 110-111,1-5 i, 205-2116$ $57,58,111,205,206$

Peanut, logr.

Penny cress.

Pepper.

Pepuer grass

Pepper, wild, water

Peppermint.

Persicaria.

Phlox

Phrymace

Phytolaccacer

Pickerel-weed.

Pigeon berry .

Pigweed (Amaranth Family)

Pigweed (Goosefoot Family)

Pimpernel (Parsley Family)

Pimpernel (Primrose Family)

Pimpernel, false.

Pinacer.

Pine Family

Pine drop

Pink Fanil

Pinweerl.

Piperaceie

Pipewort

Pitcher-plant

Plane tree.

Plantaginaced

Plantain Fanily

Plantain Indian (Composite Fanily)

Plantanaceæ.

Plum

Pogonia.

Poison ivy.

Pointed blue-eyed grass

Pokeweed .

Polemoniaceæ

Polemonium

Polygala, fringed

Polygalaceæ.

Polygonaceæ.

Polypodiaceæ.

Pondweed Family

Pontederiaceæ.

Poplar, balsam (willow Family)

Poppy.

Portulacaceæ.

Profatory note

Prickly pear.

Primrose Family

Primulaceæ

Prince's feat her

Prince's pine (Pipsisseria)

Prince's pine.

Puccoon.

Pulse Family

Purslane Family

Purslare, milk (Spurge Family)

Putty root 
Radish, wild

Ragweed.

Ragwort

$71,121,163,219$

Rannnculaces

Raspberry

Rattlesnake fern

Rattlesnake plantain (Orchis Family).

Rattlesnake weerl.

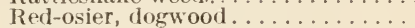

Red-root.

Red top.

Rhamnacea.

Rice.

Rice, mountain.

Rice, wild

Richweed

Robin's plantain

Rockrose Family

Rosaceæ

Rose Family

Rosemary, bog.

Rue Family.

Rue, meadow (Crowfoot Family)

Rush Family

Rush (Sedge Family). . . . . . . . .

Rush, scouring

Russian thistle.

Rutaceæ.

Rye.

$72,122,164,220$ $42-44,99-100,148-149,191-192$ $49,50,104,151,196$

$18,79,130,168$ $34,93,1.13$

$74,123,164,221$

$58,111,156,206$

54,202
84,173

$54,107,154,202$ $22,23,83-84,135,172$ $.84,135,173$

$22,83-84,135,172$

0,218

$55,10 \delta, 154,203$

$47-50,102-105,150-152,195-198$ $47-50,102-105,150-152,195-198$

$59,112,156,207$

$66,117,160,214$

$43,99,148,191$

$30-31,90-91,141-142,180-181$ $25,86,87,137,138,176$ 80,130

$41,97,147,18$

$25,86,13 \%, 175$

S.

St. John's wort Family

Salmon berry.

$54,108,154,203$ 49,104

Salsify (Oyster Plant)

Salicaceæ.

Sandalwood Family.

Sand bur

Sandwort .

Santalacex

Sapindaced

Sarraceniace ${ }^{\circ}$

Sarsaparilla (Gensing Family)

Sasafrass

Saw fly, attack of on tamarack

Saxifragaceip

Saxifrage Family

Scarlet painted cap.

Schoolcraft County, Annotated list of plants of Botanical Survey of Surface conditions of

$73,122,221$

$35-36,93-94,144,184-185$

$38-39,95-96,146,187$

$83,135,172$

$41,97,190$

$38-39,95-96,146,187$

53,202

$46,101,150,194$
$57,110,155,205$

$57,110,155,205$

81,131

47, $102,150,194-195$

$47,102,150,194-195$

$65,116,213$

$78-123$

$75-123$

62,210

Scorpion-grass

$64-65,116-117,159,212-213$

Sea-rocket

Sedge Family

Selaginella Family

$25-30,86-90,137-141,175-180$

$19,80,131,169$

$19,80,131,169$

Selaginellaceæ

Self-heal

Shepherd's purse

$45,100,149,193$

Shrubs of wide range

Silverweed.

Simarubaceæ

Skull cap

Skunk cabbage

Smart weed

Smilax. .

Snakehead

Snakeroot, black (Parsley Family)

$\ldots \ldots 49,103,196$ 52,200

$63,115,158,211$ 141,180

$39,96,146,188$

Snakeroot, (Composite Family) .

$68,119,216$

$52,20 t$

Snakeroot, (Milkwort Family) . .

Snap dragon

Snowberry (Heath Family)

Snowberry (Honeysuckle Family)

Soapberry Family.

Soapwort

Solanaceæ

Solomon's seal

Sorrel.

Southernwood

Sour-top

Sow thistle (Composite Family)

$112,157,207$

$6 \%, 160$

53,20

$42,98,190$

$63-64,116,159,212$

$32,91,142,181$

$39,96,146,188$

$60,112,157$

Sparganiaceæ

$21,82,133,170$ 
Spearmint

Spearwort.

Species, limitation of along Huron shore

speedwell

spice bush

Spikenard

Spikenard, false

Spirea

spleenwort

Spring beauty

Spruce.

Spurge Family

Squaw-root .

Squirrel corn.

Staff Tree Famil

Staphyleacea.

Starflower

Stargrass.

Steeple bush

Sticktight

Stickweed.

Stitchwort.

Stone crop

Stoneroot

Stramonium

Strawberry

Strawberry blite

Strawberry bush

Strawberry tomato

Sugar-beet

Sugarberry

Sumach

Sundew Family

Sundrop.

Sunflower

Sunflower, falst

Sweetbriar.

Sweet fern

Sweet flag

Sweet Gale Family

Sycamore.

Tamarack

Tansy.

Taxaces

Tea berry

Tearthumb

Teazel.

Thistle.

Thorn

Thymelæ

Tick-trefoil

Tiliaceæ.

Timothy

Toadflax

Toadflax (Sandalwood Family)

Todofieldia

Toothwort

Touch-me-not Family

Tree of heaven

Trees of wide range

Trillium.

Trumpet weed, Joe-pye weerl.

Tulip tree.

Tumble-weerd

Turtle hearl

Tuscola (ounty, Innotated list of plants in lotanical survey in. geograuhy, surface conditions of

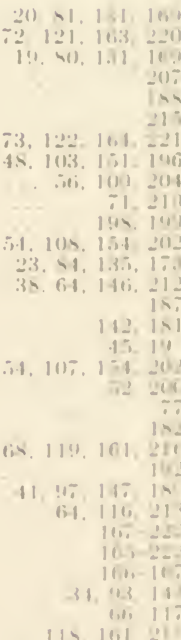

Twayblade

'Twinberry'

Twin flower.

Typhaceds 
Valerian Family

$67,118,161,21$

Valerianaceæ.

$67,118,161,21$

Velvet leaf.

$62,115,21$

Verbenaceæ.

$62,115,21$

Vervain Family.

$51,105,198,19$

Vetch

$51,105,153,19$

Vetchling

$54,108,20$

ine Family

$5.5,109,155,203-20$

Violet Family

$55,109,155,203-20$

Viburnum, sweet

$43,99,148,19$

Virgin's bower

Virginia creeper

$54,108,20$

Vitaces.

W.

Wake-robin

$32,91,142,18$

Walnut Family

$36,94,18$

Wartweed

Watercress.

Water-leaf.

Water Lily Famil

$\ddot{4} 2,98,148,19$

Water Milfoil Family

$56-57,110,20$

Water-plantain

$21,83,134,17$

Water purslane (Evening Primrose Family)

Water-star grass.

Water Starwort Family

$2 \ddot{1}, 83,134,17$

Water weed

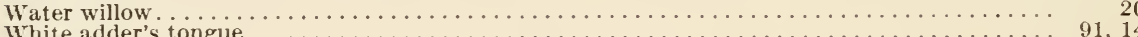

White wood

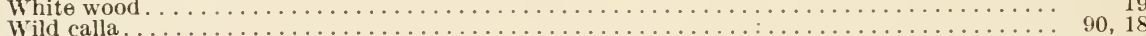

Wild celery $\ldots \ldots \ldots \ldots \ldots \ldots \ldots \ldots \ldots \ldots \ldots \ldots \ldots \ldots \ldots \ldots \ldots \ldots \ldots \ldots \ldots \ldots \ldots \ldots .21,83,134,17$

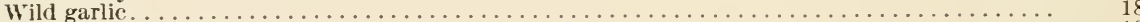

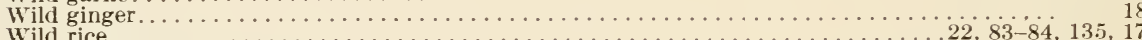

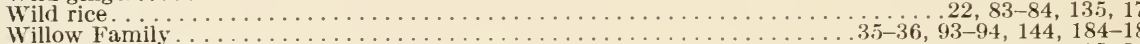

Willow-herb (Mint Family)

115,21

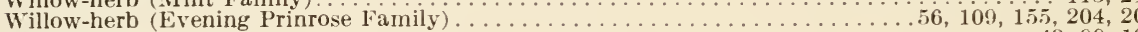

Wind-flower.

Winter berry

Wintergreen

$58,59,112,156,157,20$

witch-hazel Family

Withe-rod, (Wild raisin)

Wolfberry

Woodbine.

Wood Sorrel Family

Wood Sorr

Vormwood

$\mathrm{X}$.

Xyridacea

Y.

Yam

Yarrow

Yellow-eyed grass.

Yew Family. 




North Carolina State University Libraries QH105 .M5 A3 no. 6

MISCELLANEOUS PAPERS ON THE BOTANY OF MICHIGA |||||| || || || || || || || || || || ||| |||||||||||||||||||||||||

S02775419 K 